FERNANDO MARQUES DE CAMPOS

OS DIREITOS SOCIAIS E SUA FUNÇÃO NO CAPITALISMO

DISSERTAÇÃO DE MESTRADO

ORIENTADOR: PROFESSOR ASSOCIADO MARCUS ORIONE GONÇALVES

CORREIA

FACULDADE DE DIREITO DA UNIVERSIDADE DE SÃO PAULO

SÃO PAULO - 2010 


\title{
OS DIREITOS SOCIAIS E SUA FUNÇÃO NO CAPITALISMO
}

\author{
Dissertação de Mestrado apresentada como parte das \\ exigências para a obtenção do grau de Mestre junto ao \\ programa de pós-graduação stricto sensu, do \\ Departamento de Direito do Trabalho e da Seguridade \\ Social da Faculdade de Direito da Universidade de São \\ Paulo, sob a orientação do Professor Associado Marcus \\ Orione Gonçalves Correia.
}

DEPARTAMENTO DE DIREITO DO TRABALHO E DA SEGURIDADE SOCIAL

FACULDADE DE DIREITO DA UNIVERSIDADE DE SÃO PAULO

SÃO PAULO - 2010 
EXAMINADORES 


\section{AGRADECIMENTOS}

Quaisquer palavras de agradecimento não conseguiriam mensurar a importância das pessoas abaixo citadas para este trabalho e, muito menos para a vida que segue. Acredito que somente elas, pela frutífera convivência, seriam capazes de dimensionar sua relevância. Sendo assim, quero expressar apenas e tão somente minha gratidão e meu muito obrigado:

Aos membros da banca de qualificação - prof. Jorge Luiz Souto Maior e prof. Eduardo Carlos Bianca Bittar - pelas correções e apontamentos na exata medida e no tempo preciso; Ao prof. Paulo Eduardo Vieira de Oliveira pelos ensinamentos, quando da convivência na disciplina de Seguridade Social ao longo do $2^{\circ}$ semestre de 2008, no período noturno; Aos amigos Adryana, Giselle, Lucilla, Flávio, Marco Aurélio, Savaris, Renato, Ricardo e Thiago pelos diálogos e discussões travadas ao longo do mestrado;

Ao prof. Marcus Orione pela oportunidade, pelos ensinamentos e, sobretudo, pelas lições de vida que só um ser humano de seu quilate poderia transmiti-las;

À minha família, fonte de todo amor, paz, e, acima de tudo, o refúgio mais seguro para as horas mais duvidosas e incertas. 


\section{SUMÁRIO}

Introdução

Capítulo I) Estado entre o liberal e o social

1) Estado

1.1) A busca de um conceito

1.2) Origem e fundamento do Estado liberal

1.3) Kant - O fundamento do liberalismo moderno

1.4) Alguns pontos relativos ao desenvolvimento do Estado no século XIX

1.5) Alguns pontos relativos ao desenvolvimento do Estado no século $X X$

1.5.1) Weber - Um homem de nossos dias

1.5.2) Aspectos de três momentos relevantes do século $X X$

1.5.2.1) Weimar

1.5.2.2) Pós-Guerra - Welfare State

Capítulo II) A indissociabilidade entre capitalismo e direito

1) $\mathrm{O}$ direito privado em sua essência

1.1) Momento produção $-1^{\mathrm{a}}$ troca

1.2) Momento circulação - $2^{\mathrm{a}}$ troca

2) Relação entre direitos privado e público

3) Relação entre direitos privado e o social

Capítulo III) Direitos Sociais - Origens, limites e desconstrução

1) Primeira aproximação - enfoque político

2) Segunda aproximação - enfoque econômico

2.1) Remontando a contradição elementar do sistema

2.2) Intervenção do Estado na segunda metade do século $X X$

2.3) Crise de 2008 e seus antecedentes remotos

2.4) Crise de 2008 propriamente dita

3) Terceira aproximação - A jurídica - especificidades do texto constitucional

4) Esforço final, a Constituição de 1988 
4.1) Vicissitudes do caso brasileiro

4.2) Pano de fundo dos direitos sociais no Brasil

4.2.1) O Estado novo e a democracia liberal

4.2.2) Período militar

4.2.3) Período 1990 até hoje

5) Quarta aproximação - direitos sociais do conceito à frágil consolidação

Conclusão

Bibliografia

Resumo

Abstract 


\section{Introdução}

O título do trabalho mostra-se pretensioso ao extremo - Direitos sociais e sua função no capitalismo - mas desde já é importante deixar claro que este estudo não objetiva esgotar um tema tão amplo e complexo, tema esse que, na verdade, transcende qualquer dissertação de mestrado, pois para além do próprio entendimento do que venha a ser direitos sociais, existe hoje, sem dúvida, uma questão sensível a toda sociedade e, especificamente, à brasileira que é justamente o problema do acesso e da efetividade dos direitos sociais em um ambiente arredio a sua consolidação, iniciado nas últimas décadas do século XX e que culminou com a diminuição ou enxugamento das funções do Estado.

O objetivo geral é lançar luzes sobre o tema para além da discussão quase que fundamentalista posta pelo neoliberalismo no ínterim da globalização a respeito do quantum de direitos sociais é possível haver ou não em uma determinada sociedade ou país, uma vez que ele (o neoliberalismo) elegeu o Estado Social e, especificamente, a seguridade social como a fonte de todos os males econômicos e, simultaneamente, pôs a solução para o impasse econômico, estabelecido desde os idos dos anos de 1970 e 1980, no arrefecimento dos sistemas de proteção social, bem como de seu gestor - Estado.

O tratamento honesto deste tema requer incursões em três perspectivas, às quais este trabalho propôs-se realizar: na política, na econômica e no direito propriamente dito, derivando ao final para o caso brasileiro em razão de sua singularidade, que é o subdesenvolvimento. Nesse sentido, os três capítulos desta dissertação procuram cada qual abordar com maior ênfase cada um dos assuntos propostos à discussão.

O Capítulo I tem por escopo traçar o percurso do Estado, desde as origens do Estado liberal e, em especial, seus propósitos passando pelo Estado social e retomando o Estado neoliberal, tendo por pano de fundo as disputas entre as classes sociais, quer seja no acesso, na fruição e na consolidação, primeiramente, dos direitos civis e políticos e, posteriormente, nos direitos sociais, apartando-se de qualquer leitura linear do direito na esteira das palavras de ordem da revolução francesa (liberdade, igualdade e fraternidade) vez que nem mesmo os direitos civis e políticos foram ofertados desde o início às classes populares. De fato, são eles frutos de intensas disputas ao longo do século XIX e trajetória semelhante deu-se e dá-se com os direitos sociais no século subsequente, bem como no século XXI. Somente assim, apondo a centralidade nas disputas entre as classes, é que se pode vislumbrar e compreender o 
movimento pendular realizado pelo Estado no curso desses três séculos, mensurado com base no quantum de direitos sociais em uma dada sociedade.

No entanto, o Capítulo I deixa pelo menos, duas questões fundamentais em aberto para uma dissertação que se pretende imiscuir nos direitos sociais, quais sejam: i) a natureza e a estrutura do direito em quaisquer de suas modalidades e, sobretudo, a dos direitos sociais; ii) a célebre pergunta: afinal do que se tratam os direitos sociais?

A primeira indagação procura ser respondida pelo Capítulo II ao mostrar, apoiado nos estudos de Pasukanis complementados por Edelman, a indissociabilidade existente entre o capitalismo e o direito; e mais, como esse mesmo direito, com algumas nuanças passa a informar o todo da vida social. Quanto aos direitos sociais, sejam os individuais ou os coletivos, não se pode esquecer de que eles não deixam de ser um direito burguês no sentido de se valerem de sua forma e de promover, em última instância, o bom funcionamento do sistema capitalista com uma peculiaridade, a saber: possibilitarem uma igualdade diferente daquela ofertada pelos direitos civis e do consumidor, uma vez que operam uma nova divisão da mais valia. Sabedor dessa qualidade/potencialidade dos direitos sociais, o neoliberalismo procura reduzi-los ao máximo no espectro das possibilidades trazidas pela mudança do padrão de produção - fordismo para o toyotismo.

Percorrido o roteiro acima, o Capítulo III encontra-se apto a responder à segunda indagação ou, pelo menos, tentar respondê-la. Aqui, novamente o neoliberalismo dá pistas relevantes do que se tratam os direitos sociais, na medida tendo elegido o Estado Social como seu adversário, voltou-se ele contra a política partidária e os sindicatos. Esse movimento, de plano, é indiciário da indissociabilidade entre política e o quantum de direitos sociais angariados e o caso brasileiro é profícuo em referendar essa correlação, pois em um ambiente, no qual reinava a ausência de política (entendida aqui como disputa e consertação social), os direitos sociais foram fomentados e desenvolvidos apenas e tão somente de acordo com as necessidades do capital, no caso o fordista. E não é só, conhecedor de como se processa o modus operandi do financiamento e da fruição dos direitos sociais em um sistema de Welfare State, o neoliberalismo, na esteira do processo de financeirização do Estado como resolução da crise desse Estado social a partir dos anos de 1970, avança, por vias subliminares, sobre os direitos sociais e, mais especificamente, sobre o fundo público que o sustenta.

Pautado nesse rol de considerações é que esta dissertação procura aclarar para além da crítica incondicional que recebe por parte dos liberais e para além de seu extremo oposto a defesa incondicional - a função e os limites dos direitos sociais em uma estrutura capitalista, 
sem se esquecer de que esse Estado, sendo seu grande provedor é, também, um Estado capitalista. 


\section{Capítulo I) Estado entre o liberal e o social}

Hodiernamente, a discussão a respeito dos direitos sociais adentra a ordem do dia pela singela oposição entre o anacronismo do Estado e a modernidade do mercado com vista ao ingresso do país nos mecanismos de globalização. Todavia, a questão posta nesses termos ofusca a verdadeira querela da sociedade calcada no dilema da vida social, cujo embate travase nas esferas da política e da economia, nos quais o direito mostra-se como elemento sinalizador das perspectivas sociais engendradas, ora tentando se situar no campo da "justiça/igualdade", ora, sob a esfera da "racionalidade/eficácia"1.

Mesmo havendo uma inter-relação entre os domínios ocorre que, cada qual apresenta limites e perspectivas próprias, possibilitando sua identificação. O campo econômico informado, prioritariamente, pela racionalidade e eficácia busca no consenso e na ordem social a atuação efetiva do mercado ${ }^{2}$, como meio estruturante da sociedade; e o político, tendo como móbil a igualdade e a justiça, é o espaço do conflito e do dissenso quanto às regras vigentes nas relações sociais, e é o ambiente, por excelência, onde as ações, reivindicações e reconhecimentos por direitos se fazem presentes ${ }^{3}$.

Desse espectro, deflui que o econômico limita-se ao mundo dos interesses egoísticos e tem na figura do excluído o mote da questão social, no qual todo o problema se esgota na garantia objetiva de mínimos vitais que atendem pelo nome de suprimento de carências essenciais ${ }^{4}$. Por outro lado, o político e, mais especificamente, seu veio democrático representa a "construção de espaços do possível", podendo amplificar os horizontes da existência humana cuja possibilidade de realização insere-se em uma eventual conjugação do indivíduo no todo, na medida que bens e encargos podem vir a ser distribuídos "no conjunto da riqueza e dos valores da sociedade"

De fato, é essa a real encruzilhada sob a qual se coloca a pergunta elementar a respeito de qual modelo de Estado deve se realizar no Brasil, bem como suas indagações pertinentes à eleição do diploma jurídico diretivo da sociedade (Constituição ou legislação ordinária) e à preterição ou não de direitos sociais. Dessa forma, deve-se fazer uma

\footnotetext{
${ }^{1}$ Telles, Vera da Silva. Direitos sociais: afinal do que se trata? Belo Horizonte: UFMG, 2006, p.172.

2 Instituição jurídica oriunda do direito posto pelo estado moderno, cujos pilares são segurança, certeza, previsibilidade e calculabilidade, voltada a consecução da circulação mercantil. Grau, Eros Roberto. A ordem econômica na Constituição de 1988. 10ª ed. São Paulo: Malheiros, 2005, p.35/39.

${ }^{3}$ Telles, Vera da Silva. Direitos Sociais: afinal do que se trata?...Op.Cit., p.187.

${ }^{4}$ Telles, Vera da Silva. Ibid, p.189/190.

5 Maman, Jeannette Antonios. Fenomenologia existencial do direito. Crítica do pensamento jurídico brasileiro. $2^{\mathrm{a}}$ ed. São Paulo: Quartier Latin, 2003, p.118.
} 
aproximação preliminar com relação à discussão dos direitos sociais e não tentar qualificá-los, como uma disputa quase que fundamentalista entre o bem e o mal.

O ponto de partida da investigação remonta a Constituição de 1988, documento rotulado como de Estado Democrático de Direito ${ }^{6}$ que expõe ao longo de seu texto o conflito entre liberdade e igualdade, dilema este que deságua no social ${ }^{7}$. Passadas duas décadas, a singela constatação da não concretização dos direitos sociais respinga sobre sua própria legitimidade, deslocando a investigação do plano do poder constituído para o do poder constituinte, cujas raízes emanam da crise do Estado e da sociedade que, no limite, remonta à discussão sobre a cisão ou não entre eles ${ }^{8}$.

Nesse sentido, o quantum de inter-relação entre Estado e sociedade é o critério norteador dos modelos de Estado - liberal e social. O primeiro tem na legislação infraconstitucional, mais precisamente no direito privado civil ${ }^{9}$, o centro irradiador da produção normativa, haja vista que a constituição tem função meramente garantista do status quo, bastando à intangibilidade dos direitos de liberdade e de propriedade e a exacerbação dos momentos de legalidade em detrimento da legitimidade/justiça de modo a não autorizar a atuação do Estado pela via de políticas públicas. O outro, Estado social, tem no princípio da igualdade material (feita pela lei em sentido amplo - Constituição ou legislação ordinária a depender do país), o fundamento de atuação do Estado como agente retificador da ordem social por meio de uma série de prestações positivas com intuito de concretizar os comandos normativos de isonomia fática ${ }^{10}$. Aliás, cada concepção de Estado outorga um tipo de tratamento à democracia, lastreando-a ao econômico ou ao político que na ponta se apresenta pelo abandono ou não dos direitos sociais, que no atual estágio de nossa civilização -

\footnotetext{
${ }^{6}$ Expressão utilizada por José Afonso da Silva para contrapor-se aos estados de direito liberal e de direito social a fim de que o estado fundado na dignidade da pessoa humana logre assegurar e realizar os ditames da justiça social e da participação democrática nos mecanismos de controle das decisões. Curso de direito constitucional positivo. 26a ed. São Paulo: Malheiros, 2006, p.118/120.

Por sua vez, Paulo Bonavides classifica a Constituição de 1988 como de estado social, assentada na liberdade real e na igualdade fática, no qual o elemento democrático é implícito. Curso de direito constitucional. $22^{\mathrm{a}}$ ed. São Paulo: Malheiros, 2008, p. 378/379.

Eros Roberto Grau qualifica a Constituição de 1988 como diretiva ou programática em oposição à constituição orgânica ou estatutária, na medida em que aquela tem na intervenção estatal, seja nos momentos de produção ou de distribuição dos fatos econômicos, a pedra de toque transformadora do mundo do ser. A ordem econômica na constituição de 1988...Op. Cit., p. 71/79.

${ }^{7}$ Essa é uma palavra recorrente no presente trabalho, que se valerá da definição da Prof. Jeannette - realidade da vida cotidiana do ente humano preocupado com sua sobrevivência, ou seja, é a própria condição humana. Maman, Jeannette Antonios. Op. Cit.,p.59.

${ }^{8}$ Bonavides, Paulo. Curso de direito constitucional...Op.Cit., p.381/384.

${ }^{9}$ Bercovici, Gilberto. A problemática da Constituição dirigente: algumas considerações sobre o caso brasileiro. Rev de Informação Legislativa, Brasília, n 142, ano 36, abr/jun 1999, p.43.

10 "Grau mais alto e talvez mais justo e refinado a que pode subir o principio da igualdade numa estrutura normativa de direito positivo". Bonavides, Paulo. Curso de direito constitucional...Op. Cit., p.378.
} 
recrudescimento do viés liberal - pode ser visto elemento sinalizador de um "projeto de libertação e de emancipação" com vistas ao estabelecimento do "justo". 11

Em síntese, este capítulo move-se em torno do Estado como elemento decisivo sobre o qual os direitos sociais se erigem e para tanto reflexões a partir de Marx e de Weber a respeito da sociedade são nucleares, na medida que escrutinam as relações políticas e econômicas informadoras de nosso tempo e de nossa própria condição humana.

\section{1) Estado}

\section{1) A busca de um conceito}

Há uma questão primeira que versa sobre a própria existência e conceito do Estado. O termo Estado ${ }^{12}$ tal qual hoje se conhece foi introduzido por Maquiavel, ao desenvolver preocupações práticas quanto à estabilização do poder na península itálica no século XVI. Seu foco dirigiu-se ao cerne da existência dos Estados nacionais por intermédio de uma nova forma de organização política, irreversível para a história moderna. Todavia, esse instante nuclear foi obscurecido pela tradição clássica dos séculos XVII e XVIII ao limitar-se à discussão do Estado ao momento ex-post que, ao partir de um dado da realidade, da existência do Estado nacional unificado, estável e constituído, monta toda uma série de elucubrações sobre a relação entre os cidadãos e o príncipe, do consentimento popular ao poder, da soberania, da divisão dos poderes, dentre outros.

Desse modo, a tradição clássica não se debruça sobre a gênese do Estado nacional nem sobre a gênese da monarquia absoluta que a informa, eis aí a peculiaridade de Maquiavel que mesmo não tendo êxito em teorizar uma solução para o fato em si, isso não lhe retira o mérito de ter sido testemunha aguçada de uma percepção real: "a percepção de um começo radical, de uma nova forma de organização e de existência política, irredutível a qualquer redução teórica de fundamento e qualquer dedução, a percepção de um fato irresistivel da história moderna. Só Maquiavel é testemunha desse fato, a única testemunha que tentou

\footnotetext{
${ }^{11}$ Mascaro, Alysson Leandro. Lições de sociologia do direito. São Paulo: Quartier Latin, 2007, p.197/201.

${ }^{12}$ Bobbio, Norberto. Estado, governo, sociedade. Para uma teoria geral da política. Trad. Marco Aurélio Nogueira. $13^{\mathrm{a}}$ ed. Rio de Janeiro: Paz e Terra, 2007, p. 65/67.
} 
pensar esse fato como um problema, tendo sido encoberto por todas as teorias ulteriores do fato consumado, ou seja, da solução". ${ }^{13}$

Outro dado é relevante em Maquiavel que versa sobre a nova moral engendrada com base na cisão entre a ética (convencional ou religiosa) e a ética política e, mais precisamente, na separação filosófica entre meios e fins, na medida que o poder carece de legitimação outra a não ser pelo uso virtuoso da força que conduz ao triunfo do Estado nacional. ${ }^{14} \mathrm{O}$ ritual de passagem (do divino à política) carreia consigo algumas das principais questões debatidas pelos modernos, a saber: soberania popular versus soberania do monarca, a liberdade dos cidadãos versus autoridade absoluta do Estado, ou seja, traz a ordem do dia a dicotomia Estado e sociedade. ${ }^{15}$

A questão da origem do Estado corporifica-se com Engels ${ }^{16}$, uma vez que ele equipara o Estado a um instrumento de classe, ao conjugar, sob os auspícios da classe dominante, os monopólios do econômico e do político, em virtude da premente necessidade do primeiro. ${ }^{17} \mathrm{O}$ fenômeno histórico, denominado Estado, engendra-se da seguinte forma: o desenvolvimento das relações de produção, bem como da divisão social do trabalho nas diversas fases da humanidade que carreia consigo o rompimento dos laços de parentesco (passagem da gens à família individual) e a formatação da sociedade em classes, cuja contradição releva a necessidade do Estado, enquanto poder dissociado e alheio a esta, cujo mote é balizar por parâmetros (leis) o conflito da ordem social.

\footnotetext{
${ }^{13}$ Althusser, Louis. Política e história, de Maquiavel a Marx: curso ministrado na École Normale Supériure de 1955 a 1972. Texto estabelecido, anotado e apresentado por François Matheron. Trad. Ivone C. Benedetti. São Paulo: Martins Fontes, 2007, p. 263.

${ }^{14}$ Maquiavel trabalha em trono de duas forças antagônicas "Virtude" e "Fortuna", onde aquela tem por objetivo dominar e restringir esta para fins de obtenção do sucesso na empreitada política da perenidade do governante. Maquiavel, Nicolau. O príncipe. Trad. Antônio Caruccio-Caporale. Porto Alegre: L\&PM, 1998, p. 74, 86, 92, $120 / 124$.

${ }^{15}$ Touraine, Alain. Crítica da modernidade. Trad. Elia Ferreira Edel. $7^{\mathrm{a}}$ ed. Petrópolis: Vozes, 2002, p. 60.

${ }^{16}$ Pasukanis pontua que Engels numa passagem do livro A Origem da Família, da Propriedade Privada e do Estado dá a entender que o Estado não é um aparelho da classe dominante mas sim o resultado de uma luta na qual nenhuma das classes foi capaz de obter uma vitória decisiva. Pasukanis, ao mesmo tempo, em que aponta a ambigüidade do trecho em comento, acredita que o próprio Engels jamais concordaria com tal interpretação dada. Esta digressão do Pasukanis ao trabalho de Engles é importante na medida que Pasukanis faz daí o gancho para o tema da dominação de classe e seu velamento na sociedade. Pasukanis, Eugeny Bronislanovich. A teoria geral do direito e o marxismo. Trad. Paulo Bessa. Rio de Janeiro: Renovar, 1989, p. 114/115.

Poulantzas afirma que o problema desse trabalho de Engels reside no tratamento dado ao tema da origem do Estado que buscou pela via da historicidade de causalidade linear atrelar a divisão em classes nas relações de produção com o nascimento do Estado. Para Poulantzas, não se trata de uma historicidade linear na medida que a determinação do Estado pelas relações de produção, a primazia das lutas sobre o Estado tem temporalidades diversas em face do desenvolvimento desigual entre elas. Assim, uma forma de Estado, por exemplo, o absolutista europeu que nada mais é do que um Estado eminentemente capitalista pode anteceder as relações de produção capitalistas, pois ali vigoravam, ainda, as formas feudais. Poulantzas, Nicos. O Estado, o poder, o socialismo. Trad. Rita de Lima. Rio de Janeiro: Graal, 1980, p. 47/48.

${ }^{17}$ Engles, Friedrich. A origem da família, da propriedade privada e do Estado. Trad. Ciro Mioranza. $2^{\mathrm{a}}$ ed, São Paulo: Escala, s.a, p. 183/188.
} 
Para além de qualquer celeuma a respeito dessa obra de Engels, o que interessa aos limites dessa dissertação é verificar no Estado um ente apartado da sociedade e que se vale da lei e da força para manter a estrutura de dominação de classe. Nesse sentido, a oposição entre o arbítrio estatal e o Estado de direito ou, se quiser, entre lei e terror não consegue transcender a filosofia política do Estado burguês. Essa dicotomia vela a realidade na qual " a lei e a regra estiveram sempre presentes na constituição do poder (...) Toda forma estatal, mesmo a mais sanguinária, edificou-se sempre como organização jurídica, representou-se no direito e funcionou sob a forma jurídica." ${ }^{18}$ A correlação entre lei e ordem para a constituição do poder é um tema caro a Marx e a Weber quanto ao estudo do Estado capitalista, cujas raízes remontam as teses de Hobbes e Maquiavel sobre o Estado absoluto. Weber ${ }^{19}$ salientou que o fundamento do poder é a violência - monopólio da violência física legitima de cunho racional/legal que organiza a repressão e o consentimento pelo direito, pois este desempenha um papel singular ao estabelecer o ponto de equilíbrio entre as forças sociais pela imposição do consenso.

Esse monopólio tem como conseqüências: i) dissimulação do uso da força, ii) indução de formas de domínio via mecanismos de criação do consentimento, iii) deslocamento da legitimidade para a legalidade e da luta de classes para a disputa política de contestação ao poder. ${ }^{20}$ Sob tal perspectiva que será vislumbrado, a seguir, o Estado moderno isso sem antes deixar consignadas as linhas centrais de três vertentes do pensamento marxista sobre o Estado as quais serão utilizadas nessa dissertação sendo elas: a de Ralph Miliband, Nicos Poulantzas e E.B. Pasukanis e que, segundo Das Raju ${ }^{21}$, esses modelos permitem cada qual por um determinado ângulo ver um aspecto relevante dessa complexa realidade chamada de Estado.

Para Miliband, o Estado é um instrumento da burguesia para impor seus interesses particulares sobre o conjunto da sociedade, cujo fundamento remonta o Manifesto do Partido Comunista, no qual Marx e Engels dizem que o Estado é o comitê dos assuntos gerais da burguesia. Miliband afirma que esse controle da burguesia sobre o Estado processa-se, tanto no nível ideológico como no material, daí porque a relevância da presença de quadros formados pela burguesia com assento no Estado - no legislativo, escalões do executivo.

\footnotetext{
${ }^{18}$ Poulantzas, Nicos. O Estado, o poder, o socialismo...Op. Cit., p.86.

${ }^{19}$ Weber, Max. Economia e sociedade: fundamentos da sociologia compreensiva. V.I. Trad. Regis Barbosa e Karen E. Barbosa. $4^{\mathrm{a} e d . ~ S a ̃ o ~ P a u l o: ~ I m p r e n s a ~ O f i c i a l ~ d o ~ E s t a d o ~ d e ~ S a ̃ o ~ P a u l o, ~ 2004, ~ p . ~ 19 / 23 . ~}$

${ }^{20}$ Poulantzas, Nicos. O Estado, o poder, o socialismo...Op. Cit., p.90/94.

${ }^{21}$ Das, Raju J. State theories: a critical analysis. Science \& Society, New York, Vol. 60. No 1, Spring 1996, p. $28 / 35$ e $40 / 42$.
} 
Enfim, dos burocratas, em geral, ainda que o discurso comum seja sempre voltado para a consecução do bem comum.

Esta teoria é passível de crítica na medida que não colhe a autonomia do Estado, retirada quando este para agir no interesse geral do capital, muitas vezes, deve ir de encontro aos interesses particulares dos capitalistas. Esta concepção limita-se no mais das vezes à relação entre Estado e o interesse geral do capital, como se esse fosse um todo uno e homogêneo sem se importar com o conflito existente entre os próprios capitais, esquecendose, assim, que o Estado pode privilegiar uma fração da classe em detrimento de outras frações da mesma classe. Tal perspectiva também pode ser estendida para a relação entre capital e trabalho, nas quais muitas das políticas de Estado, em prol de reformas trabalhistas, ocorrem ao arrepio do próprio capital. E, por fim, a crítica mais contumaz a essa corrente refere-se ao fato de que não considera as restrições impostas à atuação do Estado pela estrutura capitalista de classes.

A segunda teoria, a estruturalista do Estado tem em Poulantzas um de seus expoentes. Seu ponto de partida deita-se na característica decisiva do sistema capitalista separação do produtor dos meios de produção - de onde se extrai, não só a separação entre Estado e sociedade, como também a própria natureza do Estado, conforme seja ele o fator de coesão de uma formação social e de reprodução das condições do sistema, mantendo a unidade dessa formação dividida em classes. Para o autor, o relevante é a autonomia relativa do Estado que o autoriza a desempenhar diferentes papéis a depender da classe da qual se está falando.

Para a classe trabalhadora, o Estado mostra-se como o representante geral na base dos cidadãos iguais, podendo agir, muitas vezes, a curto prazo, em sentido contrário ao interesse da classe dominante de forma a procurar remover qualquer contestação ao próprio Estado, bem como a exploração perpetrada pela classe dominante. Já para esta última, dado a sua não homogeneidade em face dos diversos interesses ali colocados, não é possível existir uma relação unidirecional entre capital e Estado, de forma que o poder político burguês assenta-se em um bloco de poder formado por uma aliança entre diversos interesses e frações de classe sob a batuta da fração hegemônica. A leitura de Estado de Poulantzas densifica-se quando ele apõe em trabalhos posteriores uma importância maior à luta de classe que passa a moldar o próprio Estado, naquilo que se chamou de condensação material de relação de poder entre as classes e suas frações. Para o autor, o Estado continua a ser um Estado burguês dividido em classes - cujo poder é fundado agora em um equilíbrio instável de compromisso, 
cuja ênfase reside no mecanismo de concessões e não no automatismo do Estado para com a classe burguesa.

A última teoria a de Pasukanis desenvolvida na década de 1920, que trabalha a gênese lógico-histórica da separação entre Estado e sociedade seja na base material como na ideológica. Para o autor, o Estado (de classe) deve aparecer como uma instituição acima e apartada da sociedade voltada à consecução do bem comum da coletividade. Só que esse Estado, ao se mostrar neutro e acima dos interesses das classes envolvidas, pondo-se como um justo árbitro, na verdade, está a garantir os contratos que informam a troca fundamental da sociedade capitalista - força de trabalho e salário - sendo, portanto, o Estado uma consequência lógica e direta dessa mesma relação, ou melhor, seu produto necessário. E caso se atenha sobre essa relação de troca de equivalentes entre os proprietários de mercadorias ver-se-á que o Estado garante, de fato, uma relação de dominação e de hierarquização social. Por ora, os esclarecimentos acima objetivam apenas e tão somente pontuar que o trabalho valer-se-á dessas concepções de Estado na busca de um melhor tratamento de seu objeto de estudo, porquanto cada uma delas dá um enfoque distinto à questão em tela.

1.2) Origem e fundamento do Estado liberal

"Os modernistas têm a consciência ingênua: eles levam a luz no meio das trevas e confiam na bondade natural do homem na sua capacidade de criar instituições racionais e, sobretudo, para o seu interesse, o que o impedem de se destruir e o conduz à tolerância e ao respeito da liberdade de cada um. Esse universo progride por seus próprios meios, pelas conquistas da razão. (...) O universo do iluminismo é transparente, mas também fechado sobre si mesmo, como um cristal. Os modernistas vivem numa bolha, protegidos de tudo que perturba a razão e a ordem natural das coisas". ${ }^{22}$

Os dizeres de Touraine são indicativos da concepção liberal de Estado que tem como contraponto o Estado absolutista e como marco histórico a revolução francesa, cujo móbil é a razão, construtora da doutrina do jus-naturalismo que divinizava o indivíduo com vistas a limitar o poder arbitrário do monarca, dando ensejo à primeira noção de Estado de direito, onde este "é a armadura de defesa e proteção da liberdade. Cuida-se com esse ordenamento abstrato e metafísico, neutro e abstencionista de Kant, chegar a uma regra definitiva que

\footnotetext{
${ }^{22}$ Touraine, Alain. Critica da modernidade...Op. Cit., p.38.
} 
consagre, na defesa da liberdade e do direito, o papel fundamental do Estado. Sua essência há de esgotar-se numa missão de inteiro alheamento e ausência de iniciativa social. „23

$\mathrm{Na}$ teoria, esse Estado edificou-se pelo contratualismo social dos séculos XVII e XVIII que aspirava estatuir, racionalmente, a existência social do homem, depositando no direito privado a função de mediação entre a ingerência do soberano e o direito de propriedade, cujos pilares são: i - $\underline{\text { domínio, }}$ o exercício do poder do monarca sobre o território do Estado e ii - pacto, princípio legitimador desse poder e do imperium, com vista a equalizar os espaços do indivíduo e do Estado. ${ }^{24} \mathrm{O}$ instrumento do contrato na medida que declara a imutabilidade de uma dada situação atinente à constituição de um país (nação), de fato, está a servir de base ideológica do status quo, qual seja: subordinação do político ao econômico, bem como o monopólio político nas mãos dos proprietários. ${ }^{25}$

Comumente, a teoria clássica queda-se envolta de aspectos da vida política; contudo, subliminarmente, ela ofusca a indissociabilidade entre Estado e capitalismo e que aquele é o esteio dos elementos (segurança e previsibilidade) necessários à edificação e ao desenvolvimento do mercado. O mecanismo, por excelência, para realizar essa tarefa é imputado ao regime liberal constitucional, cuja função é reduzir "a legitimidade da revolução à legalidade". ${ }^{26} \mathrm{E}$ mais, a associação entre direito privado e natureza racional ao mesmo tempo em que formula um conceito de direito natural moldado à imagem do direito antigo (civil romano) ela modifica o seu fundamento. ${ }^{27}$

A inversão do pensamento dos antigos autoriza o primado dos direitos naturais, ínsitos a todos os homens, frente a toda e qualquer forma de organização estatal de modo que esta somente se faz factível, caso se alicerce em um acordo entre indivíduos. Num primeiro instante, os direitos naturais amalgamaram dois opostos (indivíduo e Estado corporificado na “vontade geral”), encerrando a contradição da modernidade ancorada na racionalização e na subjetivação ${ }^{28}$. Os dois elementos informam as esferas do cidadão e do burguês; nesta, há " $a$

\footnotetext{
${ }^{23}$ Bonavides, Paulo. Do Estado liberal ao Estado social. São Paulo: Saraiva, 1961, p. 4.

${ }^{24}$ Bobbio, Norberto. Estado, governo e sociedade...Op. Cit., p.23/24.

${ }^{25}$ Losurdo, Domenico. Hegel, Marx e a tradição liberal. Liberdade, igualdade, Estado. Trad. Carlos Alberto F.N.Dastoli. São Paulo: Unesp, 1998, p. 104.

26 Bercovici, Gilberto. Soberania e Constituição: Para uma crítica do constitucionalismo. São Paulo: Quartier Latin, 2008, p.44/45.

${ }^{27}$ Estado é sinônimo de sociedade política, cuja formação é dada por um desígnio da natureza a partir da principal sociedade natural que é a família. A passagem desta para aquele é decorrência da inclinação natural do homem, a fim de viver bem ("vida honesta e feliz") ou para levar uma vida perfeita em consonância com a natureza que baste a si mesma ("honra e virtude"). A pólis não é uma comunidade erguida visando à segurança (defender-se das injustas agressões) ou ao comércio, esses são momentos anteriores a ela. Aristóteles. A política. $3^{a}$ ed. Trad. Roberto Leal Ferreira. São Paulo: Martins Fontes, 2006, p.4/6 e 53/56.

${ }^{28} \mathrm{O}$ individualismo moderno tem origem religiosa mais do propriamente racionalista, secularizada, e orientada para a produção, na medida em que "a imagem do eu" (das particularidades individuais) é uma construção do
} 
consagração do materialismo da sociedade civil e do seu membro por excelência - indivíduo egoísta independente; naquela há a consagração do idealismo estatal e do cidadão enquanto homem abstrato, genérico e moral. "29 Esse contrassenso não fica incólume ao tempo, pois quanto mais a humanidade caminhou no percurso do positivismo e do cientificismo mais a racionalização e a subjetivação apartam-se e mais as feridas da vida social afloraram-se. ${ }^{30}$

Os direitos naturais, enquanto ideologia da classe revolucionária, ofereceram as bases jurídicas de um modelo de sociedade calcado na liberdade (das forças produtivas e das relações de troca) sobre as quais o positivismo pavimentará a sociedade burguesa. Nesse sentido, os direitos naturais serviram muito mais de arma ideológica do que propriamente um princípio racionalmente explicitado e com marcas nitidamente universais, na medida "que escondem, por detrás de sua frágil armação estrutural, os interesses burgueses e sua necessidade de quebrar o antigo regime e de fazer do Estado e da política instâncias sociais dominadas por leis burguesas." ${ }^{31}$ Além do que o direito natural avalizou a proteção universal pelo direito privado e abriu um flanco importante para o primado e para a fundamentação da coação jurídica que, no limite, induzirá a equiparação do direito ao direito oficial. ${ }^{32}$

Ressalte-se, ainda, que tal concepção não logrou estabelecer qualquer mecanismo explicativo de seu tempo, restringiu-se à crítica do absolutismo. Ela simplesmente cambiou o fundamento da relação existente entre o bem e o mal (da religião para a natureza social do homem), sem ao menos lhe impingir uma utopia (democracia), o que permitiu espaço às criticas e as disputas dos séculos subsequentes. ${ }^{33}$ Essas lutas colocaram o contrato na berlinda, pois a imposição ao Estado de tarefas no campo socioeconômico somada à restrição ao mercado resultaram na transmutação, em tese, do formal ao material. ${ }^{34}$

Em suma, o contratualismo deságua numa insolúvel antinomia entre indivíduo e Estado pela criação do direito subjetivo que, no limite, representa o cerne das discussões sobre a "existência ou não de um conhecimento universal válido", de "princípios morais

cristianismo em oposição à tradição grega e a sua falta de subjetividade, onde "a psique de cada um é mais a alma em mim do que a minha alma”. Touraine, Alain. Crítica da modernidade...Op. Cit., p.43 e 49.

${ }^{29}$ Marx, Karl. $\quad$ A $\quad$ questão judaicar $\quad$ Disponível em: http://www.marxists.org/portugues/marx/1843/questaojudaica.htm. Acessado em 19/02/08.

${ }^{30}$ Touraine, Alain. Crítica da modernidade...Op. Cit., p.61/64.

${ }^{31}$ Mascaro, Alysson Leandro. Introdução à filosofia do direito. Dos modernos aos contemporâneos. $2^{\mathrm{a}}$ ed. São Paulo: Atlas, 2008, p.46.

${ }^{32}$ Pasukanis, E. B. Teoria geral do direito e o marxismo...Op. Cit., p. 36.

${ }^{33}$ Touraine, Alain. Crítica da modernidade...Op. Cit., p.23, 26/27.

${ }^{34}$ Losurdo, Domenico. Hegel, Marx e a tradição liberal...Op. Cit, p.106. 
absolutos para ação", bem como a problemática da "liberdade, da igualdade e dos direitos fundamentais". 35

\section{3) Kant - O fundamento do liberalismo moderno}

Ao discorrer sobre os fundamentos do Estado liberal, sem sombra de dúvida, há de se fazer um tributo a Kant na medida que o seu pensamento é "o pano de fundo mais bem elaborado pelos modernos para um direito natural burguês: melhor que todas as concepções jusnaturalistas anteriores porque não saído de teologia ou de verdade pré-estabelecida, mas de uma razão, universal, necessária e eterna. Ao mesmo tempo, burguesa na essência, pois que estatui a exata medida da necessidade jurídica da burguesia que ia tomando o poder estatal e jurídico nos países europeus". 36

Modernamente, Kant é a matriz sobre a qual se propala o discurso dos direitos humanos $^{37}$, porquanto "o valor exclusivamente ético do homem, pelo qual é justo que cada um, pelo simples fato de ser um ser humano seja considerado um fim em si mesmo (...). Assim, o homem por dignidade própria, como ser livre, possui um direito à participação na riqueza social (material e espiritual) (...). Só assim é redimida a sua dignidade, garantido-se lhe um direito à participação nessa riqueza, que não é fruto de mera caridade ou

\footnotetext{
${ }^{35}$ Paulo Bonavides alerta que a divergência entre os antigos e os modernos a respeito do direito natural deu-se de forma incipiente no bojo da própria antiguidade grega, quando os sofistas questionaram a noção de justiça segundo a lei (direito legislado de fundamentação metafísica) em prol da justiça, segundo a natureza biológica do homem, tendo encontrado em Sócrates, Platão e Aristóteles seus opositores. Teoria do Estado. São Paulo: Saraiva, 1967, p.187/191.

${ }^{36}$ MASCARO, Alysson Leandro. Introdução à filosofia do direito...Op. Cit., p.63.

${ }^{37}$ Para mais informações quanto ao percurso da humanidade, ver Bobbio quando discorre sobre a teoria moderna dos direitos do homem, cuja origem data das declarações de 1776 e 1789 até a Carta das Nações Unidas de 1948, mostrando a linearidade entre a teoria filosófica, a sua constitucionalização no Estado liberal, até a sua internacionalização no pós-guerra. Bobbio, Norberto. Teoria geral da política. A filosofia política e a lição dos clássicos. Trad. Daniela B. Versiani. Rio de Janeiro: Campus, 2000, p.475/488.

Fabio Konder Comparato traça o percurso dos direitos humanos no curso da historia pela tomada de consciência ética coletiva quanto à observância do principio da dignidade da pessoa humana, estabelecido com base na liberdade, como motriz do imperativo categórico. A afirmação histórica dos direitos humanos. $3^{\mathrm{a}}$ ed. São Paulo: Saraiva, 2004, p.59.

Flávia Piovesan põe em destaque o superprincípio da dignidade da pessoa humana, cujo caráter reside na aproximação do direito com a ética de modo a servir de parâmetro informativo para as ordens nacionais ou internacional, e a ser o elemento central para a reconstrução dos direito humanos no pós-guerra. E esse movimento significou um reencontro com a doutrina kantiana. Direitos humanos e o direito constitucional internacional. $9^{\mathrm{a}}$ ed. São Paulo: Saraiva, 2008, p.28/30.

José Afonso da Silva lembra que o termo direitos humanos é plurívoco e distingue direitos humanos de direitos fundamentais do homem. O primeiro dirige-se a ordem internacional e o segundo volta-se à ordem local, pela referência a princípios que resumem a concepção de mundo e que informam a ideologia política de cada ordenamento jurídico voltado à concretização de uma convivência digna, livre e igual de todas as pessoas pela limitação imposta pela soberania popular aos poderes constituídos do Estado que dela dependem. Curso de direito constitucional...Op. Cit., p.176/179.
} 
benevolência humilhantes. "38 E é, também, com base nos dois pilares de seu pensamento autonomia pessoal e o homem como fim em si mesmo - que se desenvolvem os temas da dignidade da pessoa humana e dos direitos fundamentais. Daquela, retira-se pela capacidade para a liberdade, a possibilidade do ser humano tornar-se sujeito de direitos; deste, a impossibilidade de coisificação e de instrumentalização do ser humano na ideia de homem como fim em si mesmo e não meio.

Dialogando com diversas concepções de dignidade existente hoje no pensamento jus filosófico, Sarlet expõe e fundamenta seu conceito de dignidade ${ }^{39}$ intrinsecamente relacionado aos direitos fundamentais e trata de dois assuntos pertinentes aos limites dessa dissertação: o primeiro deles, diz respeito à fundamentalidade ou não dos direitos sociais para a questão da exigência e da concretização da dignidade da pessoa humana; e o segundo versa sobre a possibilidade ou não da relativização da dignidade da pessoa humana, ou seja, cuida-se de saber se existem limites e restrições à dignidade ou se ela é um bem jurídico absoluto e intangível.

Quanto ao primeiro, Sarlet, em apertada síntese, aduz que a discussão gravita ao redor do reconhecimento ou não dos direitos sociais de cunho prestacionais (direitos a prestações fáticas e jurídicas), como fundamentais, haja vista que, para o autor, há uma clara sinalização de "um crescente consenso no que diz com a plena justiciabilidade da dimensão negativa (defensiva) dos direitos sociais em geral e da possibilidade de se exigir em juízo pelo menos a satisfação daquelas prestações vinculadas ao mínimo existencial, de tal sorte que também nesta esfera a dignidade da pessoa humana (notadamente quando concebida com o direito à vida) assume a condição de metacritério para as soluções tomadas no caso concreto o que, de resto, acabou sendo objeto de reconhecimento em decisão recente do nosso Supremo Tribunal Federal ${ }^{, 40}$ - decisão esta relativa à ADPF no 45 na qual o Tribunal, em que pese não analisar o mérito, assentou sobre a possibilidade de controle judicial na seara dos direitos sociais, mais específico no direito à saúde, notadamente, se envolver o direito à vida e a dignidade da pessoa humana. Quanto ao segundo assunto - relativização da dignidade

\footnotetext{
${ }^{38}$ Salgado, Joaquim Carlos. A idéia de justiça em Kant. $2^{\text {a }}$ ed. Belo Horizonte: UFMG, 1995, p.333.

39 A guisa de uma tentativa de síntese do conceito de Sarlet, preocupado com a diretriz de máxima eficácia e efetividade possível, tem-se na dignidade a qualidade intrínseca e indissociável de todo e qualquer ser humano, impondo tarefas ao Estado e a própria comunidade pela consecução de um complexo deposições jurídicas fundamentais, dentre os quais se encontram os direitos sociais na sua dimensão prestacional, para a satisfação das condições para uma vida saudável, e o respeito e a proteção a dignidade são o horizonte último da humanidade, do Estado e do Direito. Sarlet, Ingo Wolfgang. Dignidade da pessoa humana e direitos fundamentais na Constituição Federal de 1988. $4^{\text {a }}$ Ed. Porto Alegre: Livraria do Advogado editora, 2006, p.27, 91, 143, 144 .

${ }^{40}$ Sarlet, Ingo Wolfgang. Ibid, p.94.
} 
da pessoa humana - em que pese Sarlet trabalhar com exemplos concretos de possíveis hipóteses de relativizações da dignidade da pessoa humana quer seja na sua dimensão de princípio ou de norma de direitos fundamentais, o autor constata a prevalência na doutrina e na jurisprudência da vertente que veda a restrição à dignidade pessoal, sendo esta um valor absoluto atinente a cada ser humano, de forma que " a dimensão pessoal postula o valor da pessoa humana e exige o respeito incondicional de sua dignidade. Dignidade da pessoa a considerar em si e por si, que o mesmo é dizer a respeitar para além e independentemente dos contextos integrantes e das situações sociais em que ela concretamente se insira. Assim, se o homem é sempre membro de uma comunidade, de um grupo, de uma classe, o que ele é em dignidade e valor não se reduz a esses modos de existência comunitária ou social. Será por isso inválido e inadmissível, o sacrifício desse seu valor e dignidade pessoal a beneficio simplesmente da comunidade, do grupo, da classe." 41 No fundo, de acordo com Sarlet, essa corrente (dominante) prega o caráter absoluto da dignidade, mas trabalha com essa mesma dignidade em uma vertente restritiva, e apenas uma grave violação da condição de pessoa, de valor intrínseco do ser humano na sua condição de sujeito daria ensejo a uma violação de sua dignidade. Esta singela aproximação está a indicar que a concepção dominante no campo da dignidade e dos direitos fundamentais procura se apegar e aderir à escatologia kantiana.

Feito o breve parênteses em torno da atualidade de Kant e em face da sua relevância, é mister fazer uma incursão na sua filosofia, visto que ela é informadora do contrato social, segundo o qual todos os homens, em seus momentos "individual e particular", renunciaram à liberdade natural para retomá-la no Estado, no momento do "universal". Estado esse que resulta em um ente abstrato, apartado de qualquer causalidade fenomênica ou mesmo de contingências históricas e que tem por função validar sua própria legitimidade. ${ }^{42}$

O arcabouço kantiano é uma resposta à discussão entre idealistas e empiristas sobre a existência ou não da própria filosofia, como conhecimento do mundo. Kant volta-se à compreensão da experiência pela consciência transcendental, constituída por "formas de intuição (tempo e espaço)" e de "entendimento (categorias)", que realiza a síntese do todo apreendido pelo eu pensante. ${ }^{43}$ A clivagem sensível e inteligível recebe uma consertação em seu pensamento ao afirmar que o conhecimento empírico tem seu fundamento em um

\footnotetext{
${ }^{41}$ Sarlet, Ingo Wolfgang. Dignidade da pessoa humana...Op. Cit., p. 134. Nesse trecho, Sarlet faz referência ao pensamento de Castanheira Neves.

${ }^{42}$ Kant, Immanuel. Principios metafisicos del derecho. Nota preliminar de Francisco Ayala. Buenos Aires: Editorial Americalee, 1943, p. 151/154. No mesmo sentido, ver Bobbio, Norberto. Teoria geral da política...Op. Cit., p.106/113.

${ }^{43}$ Marcuse, Herbert. Razão e revolução. Hegel e o advento da teoria social. Trad. Marilia Barroso. $5^{\text {a }}$ ed. São Paulo: Paz e Terra, 2004, p.29/31. No mesmo sentido, MASCARO, Alysson Leandro. Introdução á filosofia do direito...Op. Cit., p. 53/58.
} 
conjunto de princípios estabelecidos a priori pela razão como condição de qualquer experiência racional - Metafísica, de tal sorte que a apreensão do objeto perpassa pela realidade, enquanto o conhecimento é transcendentalizado de modo a refutar o empírico por uma transfiguração filosófica. ${ }^{44}$

Para tanto, Kant organiza sua filosofia na "antropologia dual" ser e do ser; imperativo categórico e hipotético. A dualidade coloca o homem ("individual e particular") frente à humanidade ("universal"), faz dele, simultaneamente, um ser universal, como membro do mundo racional; e um ser singular, como membro do mundo empírico. A conexão entre os dois mundos ocorre pela "busca do universal no particular", por meio da universalização de condutas e de submissão ao dever ser. ${ }^{46}$ Kant escora a moral na idealidade platônico-cristã e, assim, produzir a metafísica dos costumes. Isso ocorre, pois o conhecimento das leis morais tem fundamento na liberdade e na "razão prática" ínsita a todo homem na medida que esta prescreve a maneira como se deve agir independente de qualquer observação de si, do mundo ou de outrem. A metafísica dos costumes divide-se em moral e direito, cuja diferenciação é de motivação e não de dever, pois aquela tem com fundamento na "legislação interna" enquanto esta, com fundamento nas "legislações interna e externa". 47

É importante deter-se aqui no imperativo categórico, pois ele perpetra a passagem do individual ao universal, conforme enuncia o princípio supremo da moral: "age segundo uma máxima" (cunho subjetivo - quer agir, livre arbítrio como regra de ação - liberdade negativa) "que possa ter valor como lei geral" (vontade da razão prática simplesmente necessária como princípio de dever objetivo - dever agir - liberdade positiva). ${ }^{48}$ De fato, o imperativo categórico é a pedra basilar da teoria kantiana de fé no progresso da humanidade, cujo móbil reside na noção de liberdade, tanto que o autor "procura garantir a liberdade no sentido negativo (com relação à natureza e com relação à imposição da vontade não pura do outro) como momento necessário do exercício da liberdade como autonomia". 49

O percurso da liberdade do particular para o universal erige a passagem do Estado de natureza (reino das relações contratuais livres, direito privado e da justiça privada) ao Estado civil (instância das relações dadas por lei, liberdade civil, pelo direito público e da justiça pública) e o episódio do contrato representa uma decorrência lógica de observância da lei

\footnotetext{
44 Bourdieu, Pierre. Meditações pascalianas. Trad. Sergio Miceli. Rio de Janeiro: Bertrand Brasil, 2001, p.65/66.

${ }^{45}$ Heller, Agnes; Feher, Ferenc. A condição política pós- moderna. $2^{\mathrm{a}}$ ed. Trad. Marcos Santarrita. Rio de Janeiro: Civilização Brasileira, 2002, p.78.

${ }^{46}$ Touraine, Alain. Crítica da modernidade...Op. Cit.,p. 31.

${ }^{47}$ Kant, Immanuel. Princípios metafísicos del derecho...Op. Cit., p. 27/28 e 33.

${ }^{48}$ Kant, Immanuel. Ibid, p. 40.

${ }^{49}$ Salgado, Joaquim Carlos. A idéia de justiça em Kant...Op. Cit., p.292.
} 
moral deduzida da liberdade que funciona como uma justificação filosófica para a sociedade civil, "que é um priori da razão que tem induvidosa realidade prática". 50

O ponto de partida é o estado de natureza como organização provisória da humanidade e que possibilita a vida dos homens sobre a terra pelo móbil da guerra, porquanto engendradora do povoamento e do estabelecimento de relações legais (direito privado) e que, no limite, caminha para uma convivência relativamente pacifica entre os homens. A viragem do ser para o dever ser - do direito privado ao direito público (político, das gentes, cosmopolita) - é atributo da razão prática, móbil da vontade geral, que tem por finalidade fomentar e a garantir a paz interna e a externa com o intuito de lograr a paz perpétua enquanto estado compatível com a liberdade. ${ }^{51}$

O Estado kantiano enquanto organização racional da sociedade humana tem por função precípua garantir a coexistência dos homens na sociedade, pela justificação jurídica dos valores burgueses da revolução francesa, que tem na liberdade o fundamento do direito e este, por sua vez, é a razão de ser do Estado ${ }^{52}$. De tal sorte que "a emancipação política é a redução do homem, de um lado, a membro da sociedade burguesa, a indivíduo egoísta independente e, de outro lado, a cidadão do Estado, a pessoa moral." $" 53$

O contratualismo kantiano assenta-se em dois pilares: a) princípios a priori (liberdade ${ }^{54}$, igualdade e independência econômica); b) autonomia da razão na condução e na realização do dever moral. A singularidade de seu pensamento reside justamente na conciliação objetiva da moral com a política pela filosofia prática, destoando dos empiristas, porquanto estes veem no Estado uma questão técnica de dominação e de justificação do poder, alheio a liberdade e ao próprio direito, na medida em que política e moral estão apartadas em virtude da relação entre fins e princípios estabelecida pela moral utilitária como velamento da força/coação. ${ }^{55}$

Extrai-se, ainda, a correlação/complementação entre a lei moral e o jus naturalismo, cujo modelo tem como critério eletivo a forma (desejabilidade de universalização das

\footnotetext{
${ }^{50}$ Salgado, Joaquim Carlos. A idéia de justiça em Kant...Op. Cit., p.284.

${ }^{51}$ Kant, Immanuel. A paz perpétua e outros opúsculos. Trad. Artur Morão. Lisboa: Edições 70, p. 140/149.

${ }^{52}$ Salgado, Joaquim Carlos. A idéia de justiça em Kant... Op.Cit., p.225.

${ }^{53}$ Marx, Karl. A questão judaica...Op. Cit.

${ }^{54}$ Uma de inspiração em Montesquieu é a liberdade como não impedimento - liberdade individual - faculdade de fazer tudo aquilo que se quer desde que não traga injustiça a ninguém; a outra é a liberdade como autonomia liberdade coletiva de clara inspiração rousseauniana - poder de dar coletivamente leis a si mesmos, ou seja, a liberdade coincide com autonomia política. Aqui se esta a falar da liberdade negativa presente no estado de natureza. Bobbio, Norberto. Teoria geral da política...p.104 e 111.

${ }^{55}$ Razão prática parte do principio formal - imperativo categórico - para o principio material - fim. A relação dada desta forma cinge as máximas da política ao dever jurídico enquanto obrigação moral informada pela razão. Kant, Immanuel. A paz perpétua...Op.Cit.,p.151/162.
} 
condutas), a fim de estabelecer um convívio social assentado no discurso universal e racionalista pelo encontro dos arbítrios, atribuindo à liberdade individual ares de licitude e de princípio supremo do Estado, sem se olvidar da garantia coercitiva, caso necessária, pelo direito $^{56}$. Todavia, os limites da teoria kantiana que têm na liberdade o móbil do progresso da humanidade (ius civitatis, ius gentium, ius cosmopoliticum), de plano, encontram-se em dissonância com qualquer noção de democracia em face de seu conceito de cidadania, reproduzindo a dicotomia alertada por Marx entre a esfera do burguês e a do cidadão, na medida que os direitos políticos têm por escopo conservar os direitos humanos/naturais propriedade, liberdade, igualdade e segurança.

Para Kant, a democracia é sinônimo de despotismo, porquanto a vontade geral reduz-se à vontade privada do governante (poder executivo), não havendo separação de poderes entre executivo e legislativo. Este último detentor da soberania informada pelo princípio da representatividade dado que permite a realização da liberdade e igualdade jurídica de modo a exercer sua independência civil enquanto membro da república. ${ }^{57}$

Em linhas gerais, Kant afirma que a noção de cidadania tal como a liberdade é dupla: ativa e passiva, cujo discrimem da qualidade de cidadão (liberdade positiva) é conferido pela noção de independência material, de tal sorte que a cidadania passiva consiste em liberdade negativa, prestando-se a balizar os limites intransponíveis pelas leis positivas, dado seu aspecto de universalidade. Por outro lado, cidadania ativa, sinônimo de liberdade positiva, remete a desigualdade civil na medida que os trabalhadores apenas "em potência" poderão participar dessa sociedade. ${ }^{58}$

Uma questão relevante é quanto à inexistente preocupação com a igualdade, pois se esta é um pressuposto da liberdade negativa, no momento da liberdade positiva, a igualdade toma dois rumos: para o proletariado, dado a sua não liberdade, não há que se falar em igualdade. Para a burguesia, a igualdade é apenas formal, pois se limita à validade da norma dado o assentimento que recebe de todos aqueles que são livres.

\footnotetext{
${ }^{56}$ Bobbio, Norberto. Teoria geral da política...Op. Cit., p.110.

${ }^{57}$ Kant, Immanuel. A paz perpétua...Op. Cit., p. 130/132.

"Liberdade jurídica - obedecer somente a lei a qual tenha sufragado; igualdade jurídica - não reconhecimento de nenhum superior exceto aquele que tenha a faculdade moral de obrigar juridicamente da mesma forma que possa vir a ser obrigado; independência civil - devedor de sua existência e de sua conservação como membro da republica segundo seus próprios direitos e faculdades". Kant, Immanuel. Princípios metafísicos del derecho...Op. Cit., p. 148/149.

${ }^{58}$ Kant, Immanuel. Princípios metafísicos del derecho...Op. Cit., p. 149/150. No mesmo sentido, Della Volpe, Galvano. Rousseau e Marx. A liberdade igualitária. Trad. Antonio José Pinto Ribeiro. $4^{\mathrm{a}}$ ed. Lisboa: Edições 70, ano 1982, p. 65.
} 
Observa-se que aqui residia o cerne do Estado liberal, enquanto Estado de direito, sob a regra da lei igual para todos - todos submetidos à mesma ordem jurídica, distante da noção de todos iguais perante a lei - haja vista a restrição aos direitos políticos. Extrai-se daí que a separação entre o social e o político tem dois aspectos: i) obstáculo à emancipação humana, ii) a ratificação do homem como ser verdadeiro apenas e tão somente na figura do burguês. ${ }^{59} \mathrm{E}$, por trás da elevação da legalidade, a universalidade encontra não apenas o processo de estabilização e de velamento do passado de violência e de desigualdade econômica, como também a assunção da planificação da lógica capitalista e dos direitos humanos (que atendem também por direitos burgueses) chancelados pelo Estado. ${ }^{60}$

Há, ainda, a questão a respeito da independência econômica, mais precisamente ao direito privado - "da maneira de ter alguma coisa exterior como sua”. Kant traça a distinção entre posse sensível e inteligível, estabelecendo o que se segue: a primeira é a posse imediata, empírica, no estado de natureza, garantida pelo próprio particular; a segunda é a posse mediata, racional, no estado civil, garantida por este último. ${ }^{61}$

A diferença fundamental entre elas está na restrição e na transitoriedade da primeira com a relação à segunda, pois somente nessa última existe o dever de obrigar o outro, seja quanto aos momentos negativos da utilização e da disposição do objeto, pois tal obrigação tem amparo na "vontade onipotente de todos" assentada na exigência absoluta da razão prática e não num aspecto experimental. ${ }^{62}$ No entanto, as duas modalidades de posse aproximam-se, na medida que a posse física representa o conteúdo da posse jurídica, declarando-a pura e simplesmente, sem a constituir como tal.

Desse modo, a pergunta subseqüente é qual o fundamento da posse física, e a resposta baliza-se em um axioma - "mais vale possuir" - como princípio de direito natural e que serve de presunção para o primeiro possuidor validar juridicamente sua posse. ${ }^{63}$ Verificase, então, o descolamento do direito natural de toda e qualquer origem política e social, indo ao encontro do direito subjetivo, pautado em um direito civil erigido a direito público de cunho contratualista em defesa do indivíduo e em oposição ao Estado e à própria sociedade. ${ }^{64}$ Assim, "a sociedade civil rompeu-se um suas partes integrantes mais simples: de um lado, os indivíduos; de outro, os elementos materiais e espirituais que formam o conteúdo de vida, a

\footnotetext{
${ }^{59}$ Marx, Karl. A questão judaica...Op. Cit.

${ }^{60}$ Mascaro, Alysson Leandro. Para uma crítica da legalidade no Brasil contemporâneo. 2002. 266 f. Tese (Doutorado em Filosofia do Direito) - Faculdade de Direito, Universidade de São Paulo, São Paulo, 2002, p. $28 / 29$.

${ }^{61}$ Kant, Immanuel. Princípios metafísicos del derecho...Op. Cit., p. 67/68.

${ }^{62}$ Kant, Immanuel. Ibid, p.73.

${ }^{63}$ Kant, Immanuel. Ibid, p.77/78.

${ }^{64}$ Mascaro, Alysson Leandro. Introdução à filosofia do direito...Op. Cit., p. 41/43.
} 
situação civil destes indivíduos. A atividade determinada de vida e a situação de vida determinada passaram a ter significado puramente individual". ${ }^{65}$

Ressalte-se, ainda, que para Kant a liberdade não é justificativa da propriedade, pois se o fosse negaria a "finalidade moral" do seu Estado. Só que assim procedendo, Kant não escapa ao "paradoxo do cidadão", dado que essa qualidade somente é exercida "depois de eliminados os obstáculos que a vida sensível impõe à vida ética". ${ }^{66} \mathrm{Na}$ verdade, Kant faz o corte de sua teoria idealista em um momento declaratório de um statu quo dado e determinado, velando, assim, a condição material por trás da moral e do imperativo categórico.

O transcendentalismo kantiano é descortinado por Nietzsche ${ }^{67}$ que o qualifica de ilusionista, uma vez que ele se vale de uma mudança de fé (divina para a moral) para lograr uma comprovação, de modo que o "mundo/verdade racional" é, na realidade, um "mundo/fantasia", chegando-se ao núcleo do dilema de Kant, "dado que nada do que o homem conhece, satisfaz seus desejos, então se busca creditar a culpa disso no conhecer, mas não no desejar. Assim, não existe conhecer: logo existe um deus. Que nova elegância do silogismo."

Nessa linha de oposição, Nietzsche ${ }^{68}$ propugna pela mudança de valores, da substituição do mundo racional para a exaltação da "vontade de poder" e da paixão, pois "o transcendentalismo está distante da liberdade do espírito. Nada é verdadeiro, tudo é permitido, isto sim é liberdade de espírito, com isto a fé na própria verdade é abandonada. De fato, tudo isso significa que a vontade do nada, uma revolta contra os fundamentos pressupostos da vida, um avesso da própria vida é e continua a ser uma vontade e o homem preferirá ainda querer o nada a nada querer".

Por fim, as considerações acima elucubram o caráter negativista do direito e o caráter ideal da sociedade. O primeiro significa "precisamente o conceito de um reino da liberdade exterior com vistas ao reino da liberdade interior, isto é com vista à liberdade abstrata que é a liberdade (originária) da pessoa dotada de valores a priori e o segundo como um reino dos fins em si". ${ }^{69}$ A correlação entre o externo/social e o interno/individual é instrumentalizada no imperativo categórico, "cujo pathos se reduz a que o homem cumpra livremente, ou seja, por convicção interna (dever) aquilo que ele seria compelido a fazer no

\footnotetext{
${ }^{65}$ Marx, Karl. A questão judaica...Op. Cit.

${ }^{66}$ Salgado, Joaquim Carlos. A Idéia de justiça em Kant...Op.Cit., p. 293.

${ }^{67}$ Nietzsche, Friedrich. Genealogia da moral. Uma polêmica. Trad. Paulo César de Souza. São Paulo: Companhia das Letras, 1998, p.137/144.

${ }^{68}$ Nietzsche, Friedrich. Ibid, p.144/149.

${ }^{69}$ Della Volpe, Galvano. Rousseau e Marx...Op.Cit., p. 26.
} 
âmbito do direito (responsabilidade patrimonial)." 70 Assim, o ser moral é um mero complemento do ser jurídico, conforme ambos estejam contidos no interior da mesma relação, mercantil.

A integração entre os elementos moral e mercantil faz do brocado kantiano "homem como fim em si mesmo" uma reprodução do individualismo econômico, de modo que a ética enquanto princípio, simplesmente é um non sense, pois "o grande capitalista arruína de boa fé o pequeno capitalista sem se importar com o valor absoluto de sua pessoa. A pessoa do proletário é igual em principio à pessoa do capitalista, isto se exprime no livre contrato de trabalho (...) com a diferença que aquele pode, tranqüilamente, morrer de fome. "71 Esta contradição ínsita a realidade social espelha o sistema racional burguês e suas construções (moral, jurídica e estatal), pois a sociedade enquanto sociedade econômica de produção e circulação de mercadorias justifica-se nos preceitos de liberdade e de igualdade formais, de modo a velar seu fundamento último, qual seja: desigualdade social, fruto da divisão em classes. $^{72}$

1.4) Alguns pontos relativos ao desenvolvimento do Estado no século XIX

“...a vida social que se imaginava transparente e governada por escolhas racionais revelou-se repleta de poderes e de conflitos, enquanto que a modernização aparecia cada vez menos endógena, cada vez mais estimulada por uma vontade nacional ou por revoluções sociais. A sociedade civil separou-se do Estado: mas se o nascimento da sociedade industrial marcou o triunfo da primeira, foi o Estado que, no século XIX, revelou-se o cavaleiro armado da modernização nacional. A distância que dessa forma foi cavada entre a modernidade e modernização, entre capitalismo e nacionalismo, levou o sonho de uma sociedade moderna à ruína, definida pelo triunfo da razão. Ela preparou a invasão da ordem clássica da modernidade pela violência do poder e pela diversidade das necessidades. "73

O parágrafo anterior delineia a contradição atinente ao desenvolvimento da humanidade no curso do século XIX; quadro esse que se faz presente, em alguma medida, no chamado Estado neoliberal em razão da similitude de muitos dos elementos aí presentes e que hoje retomam com vigor, conforme veremos no curso desta exposição. Em linhas gerais, esta trajetória é determinada em torno do embate entre as classes sociais corporificadas pelo

\footnotetext{
${ }^{70}$ Pasukanis, E.B. Teoria geral do direito e o marxismo...Op. Cit., p.131.

${ }^{71}$ Pasukanis, E.B. Ibid, p.134.

${ }^{72}$ Pasukanis, E.B. Ibid, p. 142.

${ }^{73}$ Touraine, Alain. Crítica da modernidade...Op. Cit.,p.39.
} 
quantum de direitos adquiridos (político, econômico e social). Advogando a tese contrária, os liberais veem a linearidade espontânea entre liberalismo e democracia, alheia ao conflito político e social, e que tem por mote mediato é refrear o Estado social.

A título de exemplo, pode-se valer da concepção de Bobbio $^{74}$, que, ao traçar um comparativo analítico e axiológico entre a democracia dos antigos e a dos modernos, afirma que a democracia moderna tem base filosófica no individualismo, na medida que ela é fruto do acordo entre os indivíduos singulares, ou seja, dessa realidade concreta chamada de indivíduo que é também o cidadão, não sendo, portanto, ocasional que o fundamento da democracia moderna deite-se nas Declarações dos Direitos do Homem e do Cidadão. O autor concebe o individualismo em três matizes: a primeira de ordem ética na esteira da moral kantiana; a segunda de ordem ontológica, como baseada na concepção atomista da sociedade da qual deriva a noção de contrato social, conceito este caro ao autor; a terceira de cunho metodológico, cujo ator principal é o homo econômico na qual suas ações e escolhas são informadoras da ordem social na qual é plenamente factível reduzir a democracia ao livre mercado, dado a centralidade no indivíduo. A última matiz do individualismo segue em linha com o pensamento de Hayek $^{75}$, critico fervoroso da social-democracia, equiparando-a "servidão moderna". A democracia não se compatibiliza com a liberdade econômica do indivíduo (livre disposição da renda e da propriedade), uma vez que as maiorias democracias poderiam ir de encontro aos interesses do agente econômico. Para Hayek, só a liberdade econômica do indivíduo quando somada à economia concorrencial e a desigualdade seriam elas as chaves do desenvolvimento da sociedade. É certo que Bobbio não adere ao individualismo liberal, alheio a qualquer noção de sociedade. No entanto, o autor procura trabalhar com um outro individualismo, o democrático, na base da reconciliação do homem na sociedade com base em um livre acordo entre indivíduos inteligentes com intuito de estabelecer não um todo orgânico, mas sim uma associação de indivíduos livres. Essa sua concepção, tributária ao contrato social, faz pensar a democracia moderna gravitando em função do reconhecimento dos direitos de liberdade de onde os direitos sociais se fazem prementes, pois seriam eles instrumentais para a efetivação da liberdade, haja vista que "os direitos sociais são direitos de liberdade, porque constituem a premissa indispensável para assegurar a todos os cidadãos o gozo efetivo das liberdades políticas. " 76

\footnotetext{
${ }^{74}$ Teoria geral da política...Op. Cit., p.380/382.

${ }^{75}$ Anderson, Perry. Balanço do neoliberalismo. In: Sader, Emir; Gentili, Pablo (org). Pós-Neoliberalismo: as políticas sociais e o Estado democrático. $8^{a}$ ed. Rio de Janeiro: Paz e Terra, 1995, p. 19/20.

${ }_{76}$ Bobbio, Norberto. Teoria geral da política...Op. Cit., p. 508.
} 
A relação estabelecida entre direitos de liberdade e direitos sociais, apondo estes como sustentáculo daqueles, é arquitetada, objetivando superar a antítese existente entre as duas correntes do pensamento ocidental - liberalismo e socialismo - pelo "reconhecimento de alguns direitos sociais fundamentais seja o pressuposto ou a precondição para um efetivo exercício dos direitos de liberdade. O indivíduo instruído é mais livre que um inculto; um indivíduo que tem um trabalho é mais livre do que um desempregado; um homem são é mais livre do que um enfermo." 77

Feita a digressão em torno de um autor liberal, voltemos aos dizeres de Touraine e, em especial, à querela do século XIX que gira em torno da igualdade política com a desigualdade econômica, uma vez que "não há experimento mais perigoso do que colocar a propriedade nas mãos de uma classe e o poder político nas mãos de outra. Se a propriedade não pode dispor do poder politico, o poder político porá as mãos sobre a propriedade". ${ }^{78}$ Inicialmente, esta disputa é realizada em um ambiente em que "os monopólios da produção material e da força armada" não estavam completados pelo "controle da produção espiritual”, onde se podia, ainda, ouvir os "sinos das camadas populares" em face das "trombetas da burguesia e das classes dominantes. "79.

Tal defasagem é escrutinada por Marx, na Ideologia Alemã, ao explicitar as condições históricas de produção e reprodução da vida dos homens de forma a estabelecer o primado da sociedade civil sobre o Estado, pois aquela como organização social "se desenvolve diretamente a partir da produção e do intercambio e que constitui em todos os tempos a base do Estado e da restante superestrutura idealista." 80

Esse pensar conduz a guinada da teoria clássica com a inversão do curso da história de forma que o progresso se orienta da sociedade ao Estado, uma vez que "o Estado não é a realidade de uma idéia moral, não é a imagem e a realidade da razão, ele é um produto do desenvolvimento da sociedade (...) é o poder que surgiu da sociedade e se colocou acima dela e cada vez mais foi se divorciando dela". ${ }^{81}$

$\mathrm{O}$ outro ponto de dissonância frente à teoria clássica diz respeito à dubiedade dessa relação, na medida em que a sociedade civil caracteriza-se como "conjunto das relações materiais dos indivíduos dentro de um estagio determinado de desenvolvimento das forças

\footnotetext{
${ }^{77}$ Bobbio, Norberto. Teoria geral da política...Op. Cit., p. 508.

${ }^{78}$ Schlesinger Jr, Arthur. M. The Age of Jackson, 1948, p.269 apud Losurdo, Domenico. Democracia ou Bonapartismo. Triunfo e decadência do sufrágio universal. Trad. Luiz Sérgio Henriques. Rio de Janeiro: Editora UFRJ, 2004, p.126.

${ }^{79}$ Losurdo, Domenico. Democracia ou Bonapartismo...Op. Cit., p.157.

${ }^{80}$ Marx, Karl. Engels, Friedrich. A ideologia alemã. Trad. Rubens Enderle. São Paulo: Boitempo, 2007, p. 74.

${ }^{81}$ Engels, Friedrich. A origem da família, da propriedade privada e do Estado...Op. Cit., p.184.
} 
produtivas (...) ultrapassa, por isso, mesmo o Estado e a nação, embora deva, por outro lado, afirmar-se no exterior como nacionalidade e organiza-ser perante o interior como Estado. ",2 Ou seja, a propalada cisão estanque entre Estado e sociedade não é aquela advogada pelo contratualismo liberal e para objetar tal ordem de ideias bastariam os apontamentos de Hegel $^{83}$, sem a necessidade de derivar a pensamento de Marx. Na verdade, o que existe entre o Estado e a sociedade é uma relação de reciprocidade instruída pela dialética, não a do tipo hegeliana mas, a pendular ${ }^{84}$, pois a sociedade enquanto alicerce sobre o qual se erige o Estado como superestrutura jurídica e política estabelece as relações de poder entre as classes, sob a aparência de representante de toda a sociedade, mas cuja essência resume-se na proteção dos interesses da classe prevalente. De fato, esse novo olhar sob toda a teoria política de então, correlacionando as formas políticas a um determinado modo de produção, capta “ $a$ especificidade da política no capitalismo é também a especificidade de um direito capitalista, que se elabora conforme as etapas de desenvolvimento do modo de produção". ${ }^{85}$

Nesse espectro relacional entre Estado e sociedade pensados no interior do desenvolvimento do capitalismo, Losurdo aponta três marcos históricos fundamentais para a conquista do sufrágio universal, a saber: agosto de 1792, fevereiro de 1848 e Rússia de 1917.

\footnotetext{
${ }^{82}$ Marx Karl; Engels, Friedrich. A ideologia alemã...Op. Cit., p.74.

${ }^{83}$ Hegel refuta a concepção privatística do contrato social, seja pela ficção da sua hipótese ou pela invasão do direito privado no público, na medida em que o contrato não é o elemento fundante do Estado, uma vez que o vínculo entre o estado e os súditos é permanente e irrevogável e o estado pode exigir o sacrifício da vida do súdito - bem maior e indispensável por natureza do ser humano. Assim, a teoria contratual aplicada à teoria do estado se mostra equivocada, pois aquela não se coaduna com esta, haja vista ter seus limites na propriedade privada e o estado ser um ente de natureza diversa e superior.

Sabedor das limitações dos contratualistas, a filosofia hegeliana procura a síntese entre a subjetividade e a totalidade, a partir da critica da moralidade abstrata e do interesse particular, informado pelas leis da produção e do trabalho que governam a sociedade civil. Para realizar tal tarefa, ele opõe a moralidade kantiana à ética esfera regulada pelos costumes e pelas instituições, acentuando o conceito de cidadania como a forma, por excelência, de participação ativa na liberdade, amparando-se no primado da política sobre a economia, da organização vertical sobre a horizontal, da totalidade ética em oposição ao atomismo da sociedade civil.

A liberdade em Hegel é um conceito de índole histórico-cultural fruto da luta do homem para edificar o mundo segundo a qual a pessoa possa se reconhecer, de viés material em oposição à liberdade formal de Kant, cujas condições essenciais se realizam no curso do processo histórico e não num ato de vontade posto num contrato originário. Por ser uma categoria histórica, a liberdade hegeliana é um princípio infinito onde o homem toma consciência de sua racionalidade subjetiva que se enriquece pelo desenvolvimento da comunidade. Losurdo, Domenico. Hegel, Marx e a tradição liberal...Op.Cit.,p.86/92.

Enquanto Kant trabalha na perspectiva da dualidade - universal (humanidade - todos os indivíduos) e singular (individuo - ser humano) de modo a conceber o seu estado como estado hipotético, normativo, na imanência objetiva e histórica avaliado filosoficamente; a seu turno, Hegel estabelece um modelo triádrico, composto pelo universal (estado - generalidade de todas as particularidades que surgem em torno das instituições da sociedade civil), singular (individuo- cidadão individual) e o particular (família e sociedade civil), de modo que o percurso da subjetividade à totalidade do espírito objetivo se faz pela elevação da consciência do individuo à comunidade, ou melhor, do racional em si ao para si. Heller, Agnes; Feher, Ferenc. A condição política pós-moderna... Op. Cit.,p.82/83.

${ }^{84}$ Bobbio, Norberto. Nem com Marx, nem contra Marx. Trad. Marco Aurélio Nogueira. São Paulo, Unesp, 2004, p.139.

${ }^{85}$ Mascaro, Alysson Leandro. Para uma crítica da legalidade no Brasil contemporâneo...Op. Cit., p.59.
} 
Momentos esses refreados, em regra, pelo advento de Estados de exceção (Napoleão Bonaparte, Louis Napoleão, Fascismo, Nazismo e a "Democracia Americana"), como "resposta das classes dominantes aos ataques das classes subalternas". 86

Nesse entre meios, vai se assistir ao surgimento de um mecanismo institucional relevante para sobrepujar o poder constituinte - o constitucionalismo. A conjugação de duas ideias - a da impossibilidade de uma revolução permanente e a de que o sucesso de uma revolução culmina na construção de uma nova ordem política (política no sentido de paz e estabilidade) - vai permitir a "redução da legitimidade à legalidade. Com o discurso exclusivo da legalidade, a distinção entre normalidade e exceção perde o sentido, pois a exceção, ao ser legal, assume as vestes de normalidade "87. É interessante observar aqui como se dá a trajetória da exceção no curso dos séculos XIX e XX, pois se naquele, o Estado vai valer-se da incorporação do instituto da exceção a fim de em um momento inicial lograr salvar-se a si próprio e, por conseguinte, o mercado pela garantia da constituição. Neste último, a via da exceção passa a ser o garante direto do próprio sistema capitalista, sem, contudo, modificar sua finalidade precípua, qual seja: "tentativa permanente de exclusão do poder constituinte do povo". ${ }^{8}$

Os acontecimentos da revolução francesa gravitam ao redor da disputa entre democracia e ordem, que culminaram na substituição da política pelo direito, como forma de refrear a revolução pela constituição, com base na assunção da lógica da soberania posta na universalidade dos cidadãos. Sem olvidar que, na fase do 18 de Brumário, a soberania retornou às mãos do monarca, após uma breve gestação no povo. ${ }^{89}$

O interessante aqui é que no momento da soberania do povo, a tradição liberal equiparou o trabalho assalariado ao trabalho escravo e fez da divisão do trabalho o critério da discriminação censitária, de modo que a ideia de representação valeu-se da lógica do privilégio do antigo regime. Apartava-se, assim, qualquer relação entre sufrágio e direito pelo mecanismo das castas, haja vista a necessidade de manter o povo sob o julgo agora não mais de um rei absoluto mas sim de "notáveis". 90

Na mudança estrutural do regime político (absolutismo para o liberalismo), o direito respondeu à anormalidade do fato revolucionário com o constitucionalismo (1815/1830) que objetiva findar a revolução pela legitimação da monarquia parlamentar de modo a preservar a

\footnotetext{
${ }^{86}$ Losurdo, Domenico. Democracia ou Bonapartismo...Op. Cit., p.56/60.

${ }^{87}$ Bercovici, Gilberto. Soberania e Constituição...Op.Cit., p.45.

${ }^{88}$ Bercovici, Gilberto. Ibid, p.46.

${ }^{89}$ Bercovici, Gilberto. Ibid, p. 150/151 e 158.

${ }^{90}$ Losurdo, Domenico. Democracia ou Bonapartismo...Op. Cit. p.46.
} 
cisão entre Estado e sociedade e, por tabela, o mercado. No mais, a constituição sistematiza as relações entre os poderes, arrola os direitos individuais e remete à garantia da liberdade e da igualdade à lei, mais precisamente ao código civil. Isso se faz necessário a fim de evitar "o primado da constituição" e, por conseguinte, do político sobre o direito posto, enquanto voltado aos objetivos do mercado. ${ }^{91}$

A fim de ilustrar o período histórico, pode-se valer da Critica da Filosofia do Direito de Hegel, obra que aponta para o tema da conciliação da sociedade no Estado, mais precisamente, na monarquia constitucional como progresso racional do espírito humano, na medida que Hegel adere ao pressuposto do pensamento filosófico tradicional - supremacia ontológica do Estado, porquanto a "sociedade civil não se realiza como universal concreto pela superação na própria sociedade da particularidade da propriedade privada, aí a sociedade apenas conquista uma universalidade abstrata permanecendo intocada pela particularidade dos interesses ". 92

Marx contrapõe-se a Hegel em dois momentos, a saber: i) método, ii) resultados que engendram sua concepção de Estado - organicista, monarquia constitucional, a burocracia como classe universal e a representação por grupos. Quanto ao primeiro ponto (dialética hegeliana) o confronto metodológico entre os autores ocorre, mais especificamente, com a inversão ontológica processada entre o real e o ideal, de forma a transformar o primeiro em um produto lógico e racional do segundo e, assim, atribuir à centralidade na manifestação da idéia lógica. Esta inversão transforma uma proposição empírica em metafísica, levando a uma falsa percepção da realidade e a criação do "homem teorético". 93

Aliás, de acordo com Marx, "Hegel dá a sua lógica um corpo político, ele não dá a lógica do corpo político (\$287)","s4 "sua dialética volta-se para a superação do saber, por meio dos momentos do movimento, partindo do direito privado até a história mundial ${ }^{95}$, superando a teoria do Estado, mas não o próprio Estado. O $§ 262$ dessa obra é uma boa amostra do misticismo hegeliano ao estatuir a ideia abstrata de Estado como totalidade superior e anterior às partes (família e sociedade civil como momentos objetivos da ideia). Hegel faz do Estado, o sujeito universal à semelhança do que fizera à teologia com Deus, de modo que a filosofia hegeliana imiscui-se no idealismo ${ }^{96}$. Marx, no entanto, rende-se aos méritos da dialética, na

\footnotetext{
${ }^{91}$ Bercovici, Gilberto. Soberania e Constituição...Op.Cit., p. 165 e 168.

92 Apresentação de Enderle, Rubens. (In) Marx, Karl. Crítica da filosofia do direito de Hegel. Trad. Rubens Enderle e Leonardo de Deus. São Paulo: Boitempo, 2005, p.16.

93 Apresentação de Enderle, Rubens. (In) Marx, Karl. Crítica da filosofia do direito de Hegel...Op. Cit., p.19.

${ }^{94}$ Marx, Karl. Crítica da filosofia do direito de Hegel...Op. Cit.,p.67.

${ }^{95}$ Marx, Karl. Manuscritos Econômico-Filosóficos. Trad. Jesus Ranieri. São Paulo: Boitempo, 2004, p.130.

${ }^{96}$ Apresentação de Enderle, Rubens. (In) Marx, Karl. Crítica da filosofia do direito de Hegel...Op. Cit., p.20.
} 
medida que ela se presta a demonstrar "o estranhamento universal da essência humana e do ato de pensar como momentos do processo de abstração”. O processo ocorre, pois Hegel apreende o trabalho como essência do homem, como ato de produção de si do homem, ele apreende o sentido positivo do trabalho, o abstratamente espiritual, "comportar-se para consigo mesmo como essência estranha e sua atividade, enquanto essência estranhada, como a consciência genérica e vida genérica vindo a ser". ${ }^{97}$

Com relação ao segundo ponto (concepção de Estado de Hegel), Marx denuncia a alienação política, opondo a monarquia constitucional de Hegel à democracia cuja base está no povo concreto. "Em todos os Estados que diferem da democracia o que domina é o Estado, a lei, a Constituição, sem que ele penetre materialmente o conteúdo das restantes esferas não políticas. Na democracia, a Constituição, a lei, o Estado é apenas uma autodeterminação e um conteúdo particular do povo, na medida em que esse conteúdo é constituição política $^{, 98}$.

A inversão ontológica entre o povo e a constituição permite a Hegel estabelecer a oposição entre Estado político e não político e sua síntese na constituição como ideia de Estado. Esta lógica acarreta, segundo Marx, duas inflexões ao conceito de Constituição, ${ }^{99}$ derivadas do fato de que o povo ao integrar a constituição ele o faz como sociedade civil e não como princípio informador daquela. E, isso, gera tensões em dois níveis: i) "entre constituição e poder legislativo"; ii) "entre poder legislativo e poder governamental", na medida em que o poder legislativo reduzido à parte não pode modificar o todo, ou seja, o povo não pode se dar nova Constituição. O legislativo, como parte pode-se chocar com o poder governamental. No fundo, esses embates servem para mostrar o conflito maior engendrado entre povo e Estado.

As críticas de 1843 levam Marx a uma solução primeira, qual seja: a via democrática de modo que a questão política seja vislumbrada sob a ótica da absorção do Estado pela sociedade civil, núcleo da verdadeira democracia, lócus de superação do antagonismo entre o político e o não político por meio do sufrágio universal. "A democracia não cria uma existência política para além da existência privada do homem, ela apenas restitui ao homem a sua essência política (...) Democracia é a máxima generalização possível da eleição." 100

A opção primeira de Marx pela democracia, mais precisamente, a formação da vontade geral, para além da individual, fixada na ideia da soma das diferenças dos particulares

\footnotetext{
${ }^{97}$ Marx, Karl. Manuscritos Econômico-Filosoficos...Op. Cit., p.124,132,133.

${ }^{98}$ Marx, Karl. Crítica da filosofia do direito de Hegel...Op. Cit., p.51.

${ }^{99}$ Marx, Karl. Ibid, p.74/77.

${ }^{100}$ Marx, Karl. Ibid, p.134.
} 
- não todos, singularmente, mas, dos singulares como todo ${ }^{101}$, e ao que tudo indica, será este o gancho da passagem do político ao social ${ }^{102}$, uma vez que a vontade tem fundamento nas relações materiais assentadas na propriedade privada.

A partir daí, abrem-se as vias para Marx estabelecer o primado da economia e sociedade sobre a política que desembocará no sistema da estrutura e superestrutura e, também, a traçar o aspecto essencial das revoluções burguesas - limitadas às formações políticas do Estado (quer sob a forma da monarquia ou sob a república), deixando incólume o cerne econômico (forças produtivas e formas burguesas de produção) - ao mesmo tempo em que se presta a desvelar pela história o caráter da dominação burguesa. ${ }^{103}$

Prosseguindo no curso do século XIX, o momento subsequente é o das lutas de classe na França de 1848/1850, cujo sufrágio fora estendido ao universo masculino e a realidade burguesa teve de mostrar, ao final, a sua face verdadeira. Conquista do sufrágio masculino fora neutralizada, de plano, pelo advento do líder carismático, o único capaz de garantir a propriedade contra um legislativo inflado pelo "pathos do citoyen e das reivindicações das classes populares". ${ }^{104}$ Frente à primavera dos povos, aquele Estado de direito não intervencionista e neutro iria se valer: primeiro, da incorporação do estado de exceção - estado de sítio - ao texto constitucional, rompendo com a normalidade liberal antes anunciada, a fim de servir de instrumento de conservação da ordem burguesa dos constantes ataques advindos do social.

Bercovici, fazendo remissão a Hans Boldt, vai dizer que as questões candentes do século XIX, tais como, a industrialização, a anunciada democracia de massas e o social em sua completude e força vão exigir do Estado liberal uma ordem jurídica especial, chamada de estado de sítio, cujos fins seriam: "garantir o poder do Estado, a liberdade constitucional e a sociedade liberal burguesa contra os radicalismos dos democratas, comunistas e anarquistas. A reflexão liberal sobre o estado de exceção, geralmente, se refere aos atentados que podem ser cometidos contra a ordem político-social existente não pelo executivo, mas sobretudo pelo legislativo. Os autores liberais têm receio da ameaça à propriedade que pode significar a adoção do espírito igualitário pelo legislativo." 105

A explosão dos acontecimentos de 1848/1850 fez com que a burguesia fosse obrigada a desvelar o véu que recobria sua face e escrutinasse seu verdadeiro interesse, uma

\footnotetext{
${ }^{101}$ Marx, Karl. Crítica da filosofia do direito de Hegel...Op. Cit., p.131.

${ }^{102}$ Prefacio de Enderle, Rubens. (In) Marx, Karl. Crítica da filosofia do direito de Hegel...Op. Cit.,p.26.

${ }^{103}$ Marx, Karl. A revolução antes da revolução. São Paulo: Expressão Popular, 2008, p. 74, 97 e 183.

${ }^{104}$ Losurdo, Domenico. Democracia ou Bonapartismo...Op. Cit., p.67.

${ }^{105}$ Bercovici, Gilberto. Soberania e Constituição...Op.Cit., p.217/218.
} 
vez que para "preservar intacto o seu poder social, tem que enfraquecer seu poder político; que o burguês particular só pode continuar a explorar as outras classes... sob a condição de que sua classe seja condenada, juntamente com as outras, à mesma nulidade política: que a fim de salvar sua bolsa; deve abrir mão da coroa, e que a espada que a devia proteger é também suspensa sobre sua cabeça, como a espada de Damôcles. " 106

Tal atitude é uma demonstração clara de que o Estado alimenta-se da vida civil (esfera na qual a divisão do trabalho e sociedade privada são poderes independentes da vontade dos indivíduos) e não da vida política. Por conseguinte, o Estado não é o fator decisivo perante a sociedade, pelo contrário, ele é intrumentalizado pela classe dominante sob a forma jurídica da exploração.

O período como um todo foi célebre em personificar um líder carismático de relação direta com as massas (desarticuladas) e cujo papel objetivava: i) pelo nacionalismo, dissimular o social; ii) obstar a atuação do legislativo de modo que "até mesmo uma moderada redistribuição da renda pela via legislativa deve ser considerada um ataque à propriedade que provoca, ou pode provocar, o estado de exceção". ${ }^{107}$ Esses acontecimentos serviram para ilustrar o quão importante é a natureza do Estado, pois independente do titular do poder ou de eventuais rompimentos com a legalidade posta (no presente caso, a ditadura burguesa do executivo consolidada a fim de manter o status quo e de arrefecer o inimigo - o proletariado), o relevante é que o Estado seja burguês, identificado nos interesses que aí prevalecem. ${ }^{108}$

A constatação do parágrafo anterior vai reverberar de alguma maneira no encaminhamento dado à Comuna de Paris em 1871, como experiência de movimento de massas, tornando-se classe dominante e, mais especificamente, quanto à sua organização, malgrado seu insucesso. Ali, na Comuna, o importante, segundo Marx, ${ }^{109}$ que escreveu no calor dos acontecimentos e anos depois o testemunho confirmatório de Lenin ${ }^{110}$ quanto aos destinos da revolução russa em curso, é que o enquadramento que se daria à democracia de modo a constituir uma "forma positiva de República", com o detalhe fundamental de que não seria essa República quem daria cabo à dominação do capital nem com a luta de classes. Ela, na verdade, prestaria a robustecer os interesses das massas, cuja possibilidade desaguaria na própria ditadura do proletariado.

\footnotetext{
${ }^{106}$ Marx, Karl. A revolução antes da revolução...Op.Cit., p.263/264.

${ }^{107}$ Losurdo, Domenico. Democracia ou Bonapartismo...Op. Cit., p.110.

${ }^{108}$ Marx, Karl. A revolução antes da revolução...Op. Cit., p. 176, 177 e 196.

${ }^{109}$ Marx, Karl. Ibid, p. 398/406.

${ }^{110}$ Lenin, Vladimir Ilitch. O Estado e a revolução: o que ensina o marxismo sobre o Estado e o papel do proletariado na revolução. Trad. Aristides Lobo. São Paulo: Centauro, 2007, p. 62/78.
} 
Marx sabedor, com base nas experiências de 1848, do poder do Estado ("grande instrumento nacional da guerra do Capital contra o Trabalho"), via na possibilidade do encaminhamento dado à Comuna uma forma de suprir a dominação não só a monárquica como também a da classe (burguesa) naquilo que se denominou de "antípoda do Império" (do segundo império francês). A Comuna foi no âmago do Estado burguês ao suprimir o exército e a polícia pelo povo armado, a burocracia regular pela elegibilidade, amovibilidade e pelo fim do privilégio do funcionalismo como forma de quebrar o Estado burguês e de substituir sua democracia por uma democracia de mais qualidade, ou seja, por uma democracia proletária assentada em um "governo mais barato", pois só a partir dessas medidas reformistas deve-se dar um encaminhamento para a transformação socialista do Estado.

Outro ponto de relevo, que merece destaque, é o tratamento outorgado pela Comuna ao parlamento burguês, mudando-lhe sua finalidade, ou melhor, suprimindo-lhe, sem se esquecer da relevância e da importância dos instrumentos de representação e de eleição para a consecução da democracia proletária. A essência do parlamentarismo burguês seja ele de que tipo for (monarquia ou república) era, até então, a de se limitar a escolher qual membro da classe dominante iria oprimir e esmagar o povo no parlamento, razão pela qual esse mesmo parlamento deveria ser substituído "por instituições onde a liberdade de discussão e de exame não degenera em intrujice; os próprios mandatários devem trabalhar e eles mesmos fazer executar as suas leis, verificar os resultados obtidos e responder diretamente perante os seus eleitores. As instituições representativas são mantidas, mas já não há o parlamentarismo como sistema especial, como divisão do trabalho legislativo e executivo, como situação privilegiada para os deputados. Não podemos fazer idéia de uma democracia, mesmo proletária, sem instituições representativas, mas podemos e devemos realizá-la sem parlamentarismo..."

Retomando o curso da história, dado que a experiência da Comuna mostrou-se um ponto fora da curva, o final do século XIX foi caracterizado pelo avanço das ideias socialistas em associação com a organização política e sindical das massas que propiciaram a conquista do sufrágio direito e universal, a ponto de Engels ${ }^{112}$ constatar que, por meio dessa via, o operariado obteve vitórias significativas contra as instituições burguesas, o que lhe abriu um flanco importante para a transformação social. Ao mesmo tempo, em que pôs na berlinda a legalidade burguesa que não resta opção, exceto a de romper reiteradamente com sua própria legalidade nos instantes de dissensão do sistema capitalista. Todavia, os potenciais efeitos

\footnotetext{
${ }^{111}$ Lenin, Vladimir Ilitch. O Estado e a Revolução...Op. Cit., p. 75.

${ }^{112}$ Introdução de Engels, Friedrich. (In) Marx, Karl. A revolução antes da revolução...Op. Cit.,52, 59, 60.
} 
dessa realidade foram refreados pelas armas (econômica, política e ideológica) das classes dominantes ${ }^{113}$.

Em linhas gerais, tal empreitada deu-se pela oposição da burguesia, apoiada em um momento de bonança e de expansão do sistema capitalista, à imprensa e ao partido operário. Àquela, seria ela objeto de uma ação econômica, cuja derivação cai no que é hoje conhecido como "mass-media" (resultado de processo de concentração que assegura o monopólio sobre a imprensa pela burguesia em face da necessidade de investimentos pesados requeridos por este tipo de imprensa), e, sobretudo de uma ação política apoiada na idéia de uma imprensa chancelada de independente, livre dos partidos (mas, controlada pelo capital). Já o partido e, em especial, seu modus operandi, teria de se defrontar com o apelo burguês ao individualismo, na medida que o partido organizado é denunciado como uma "escola de submissão servil e instrumento de intimidação que reprime e pisoteia o indivíduo."

Esses dois fronts abertos pela burguesia diante do proletariado objetivaram, em última instância, o enfraquecimento ou, até mesmo, a dissolução dos partidos organizados, a fim de que possa ser consagrado "o monopólio dos meios de produção espiritual nas mãos de um pequeno circulo privilegiado que não encontra mais nenhuma resistência organizada à sua obra de manipulação. (...) Verifica-se uma assustadora queda no nível do debate político e a atomização da massa cria os pressupostos do triunfo do bonapartismo, baseado na relação, mais desigual do que nunca, que vê, por um lado, o líder, que pode apelar aos meios de comunicação mais poderosos e às técnicas mais refinadas de persuasão oculta e de manipulação, e, por outro, uma multidão agora verdadeiramente criança, porque cada vez mais destituída de toda e qualquer organização e expressão autônoma". 114

Não se pode esquecer ainda da atuação do direito e, mais especificamente, do constitucionalismo no curso do século XIX que se mostrou um importante adversário ao poder constituinte, ao reforçar a estabilidade liberal diante das tentativas do avanço democrático, visando "evitar a degenerescência da forma política liberal, buscando encerrar a contingência e o dinamismo da política expostos por Maquiavel." ${ }^{115} \mathrm{O}$ processo todo se deu pela supremacia do direito em face da política na medida em que os juristas teorizam a soberania com base no Estado/nação, em franca oposição a Rousseau, tendo em vista: i) engessar o poder constituinte, subordinando-o às competências do poder constituído, ii) absorver o criador (povo) na criatura (Estado), iii) outorgar ao Estado a condição de sujeito de

\footnotetext{
${ }^{113}$ Losurdo, Domenico. Democracia ou Bonapartismo...Op. Cit., p.159/165.

${ }^{114}$ Losurdo, Domenico. Ibid, p.164.

115 Bercovici, Gilberto. Soberania e Constituição...Op.Cit.,p.176.
} 
direito de forma a possibilitar sua atuação como empresa, iv) pressupor a política como instante ex ante da constituição e, portanto, dela apartada, v) reduzir a constituição a uma técnica para fins de garantia da estabilidade. ${ }^{116}$

O móbil desse Estado liberal remete à esfera autônoma da lei, entendida como um ordenamento lógico racional e coerente a reger uma sociedade harmônica sem conflitos, a fim de garantir a certeza dos valores liberdade e igualdade formais. Pari passo ao desenvolvimento do Estado e da sociedade burguesa, que o informa no curso deste século (de revolucionária à conservadora, na medida que ela associava-se cada vez mais ao exercício poder), é interessante observar o percurso do direito e, em especial, daquilo que se entende por lei natural, e o do positivismo, de método revolucionário no século XVIII para justificação científica da ordem social estabelecida no século XIX.

Quanto a este último, se no campo das ciências naturais, ele serviu de instrumento de crítica e de contestação aos dogmas e aos axiomas da Igreja; no campo das ciências sociais, a recepção e a utilização da neutralidade e da objetividade como princípio de tratamento dos fenômenos sociais tal como fora feito com os fatos naturais, submetidos agora a leis naturais, vai servir bem aos anseios da burguesia, na medida em que tal equiparação fomenta a consolidação e a legitimação da ordem burguesa pela resignação a partir da convicção da invariabilidade das leis. Leis essas infensas a qualquer vontade humana, o que finda por vedar qualquer tratamento à questão, por exemplo, da desigualdade social, sob pena de ser tachado de anti-científico. Aliás, segundo Lowy, o positivismo aplicado às ciências social tem seu mentor maior em Durkheim a ponto de seu trabalho - La division du travail social propugnar por aproximar a sociedade a um ser vivo na base da classificação orgânica onde “certos órgãos sociais têm uma situação especial e, se se quer, privilegiada; situação evidentemente natural, funcional e inevitável: ela se deve à natureza do papel que ela cumpre e não a qualquer causa estranha a suas funções. Este privilegio é, portanto, um fenômeno absolutamente normal que se encontra em todo organismo" ${ }^{\text {117 }}$. Se essa singela aproximação parece aos olhos de hoje até certo ponto pueril, ela dará uma contribuição importante ao advento do funcionalismo do século XX.

Verifica-se, por fim, que a modernidade carreia consigo seu triunfo e sua decomposição, na medida que o movimento de libertação (primeiro da separação entre igreja e Estado, depois da separação entre Estado e sociedade) pela busca da verdade impessoal com

\footnotetext{
${ }^{116}$ Bercovici, Gilberto. Soberania e Constituição...Op.Cit., p. 242/243 e 262/263.

${ }^{117}$ Löwy, Michael. As aventuras de Karl Marx contra o Barão de Münchhausen: marxismo e positivismo

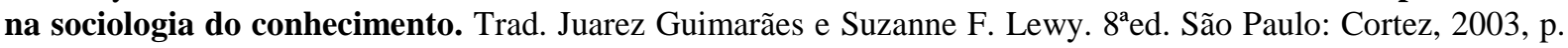
27.
} 
base na ciência e no êxito econômico tem como ponto final o questionamento dos seus próprios êxitos que recaem em um niilismo informado pela perda de sentido, dada pela técnica e pela razão instrumental. ${ }^{118}$

A civilização burguesa estabelecida a partir da correspondência entre o desenvolvimento pessoal e a integração social conduz ao dilema do asceticismo intramundano - volta da consciência moderna contra si que leva ao esvaziamento do homem, à sua decadência e, posterior, desaparecimento, na medida que a confiança no progresso esvai-se com a história, ou melhor, que essa confiança concretiza-se apenas pela figura da nação e a do homem abstrato, sem deixar espaço para a liberdade humana. ${ }^{119}$

\section{5) Alguns pontos relativos ao desenvolvimento do Estado no século $\mathrm{XX}$}

"O processo de emancipação que, nos últimos dois séculos, conquistou o sufrágio universal e igual (uma cabeça um voto), reivindicou a representação proporcional em nome do mesmo valor representativo de cada voto, contestou o monopólio (independentemente de como se configurasse ou camuflasse) dos órgãos representativos por parte da riqueza, associou direitos políticos a direitos sociais e econômicos, viu e celebrou a democracia como emancipação das classes, das raças e dos povos mantidos em condições de subalternidade tal processo parece ter sofrido uma grave interrupção. Nesse sentido, estamos diante de uma fase de des-emancipação, uma daquelas que caracterizam o caminho longo e tortuoso da democracia, mas cuja superação por ora não se consegue entrever." 120

As considerações acima dão bem uma amostra do caminho tomado pela disputa política no curso do século XX que se engendra por condições outras, afeitas aos domínios materiais e não apenas aos formais e que potencializada por dois conflitos mundiais iria requisitar uma gama maior de esforços do "estado de exceção" com vistas agora a não mais preservar o próprio Estado e sim a preservar o modelo capitalista. ${ }^{121}$

A expansão do Estado sob o domínio social tem como consectário imediato à ampliação de sua dimensão de poder, bem como o reforço de sua autoridade originária - força propriamente dita - tornando-se assim um sujeito forte e autômato, na esteira da ideia weberiana de Estado como empresa econômica. O Estado assume um papel diferente daquele desempenhado no século XIX, conforme é convocado a intervir constantemente na vida

\footnotetext{
${ }^{118}$ Touraine, Alain. Crítica da modernidade...Op. Cit., p.102/103.

${ }^{119}$ Touraine, Alain. Ibid, p. 116/126.

${ }^{120}$ Losurdo, Domenico. Democracia ou Bonapartismo...Op. Cit., p.333.

${ }^{121}$ Bercovici, Gilberto. Soberania e Constituição ...Op.Cit.,p.285.
} 
econômica e no conflito social, amplificando o discurso de adaptação da sociedade ao modelo capitalista, tornando-se, desse modo, um ator relevante para o consenso.

Nesse sentido, Poulantzas ${ }^{122}$ assevera que as modificações das relações de produção, da divisão do trabalho, da reprodução da força de trabalho, dentre outras experimentadas pelo capitalismo engendram uma alteração qualitativa do papel do Estado, migrando da marginalidade de outrora para o centro em matéria de função econômica, de modo que esta se traduz pelos efeitos da articulação entre Estado e economia, tendo em vista a acumulação e reprodução do capital. A função econômica do Estado torna-se, no século XX, o elemento determinante de sua atuação, de forma que as medidas econômicas adotadas têm um quê de político, pois não só são voltadas às necessidades de acumulação e reprodução do sistema, como também elas instrumentam as funções tradicionais do Estado - repressiva, ideológica, preservação da ordem e, até mesmo, na organização do consenso, ou melhor, "trata-se de uma política econômica prodigiosamente contraditória em si." 123

Esse modo de ver a primazia das ações econômicas do Estado não apartadas ou dissociadas das demais funções desse mesmo Estado tem o mérito de trazer a baila uma questão importante para o século XX que é o declínio das instituições democráticas e, em especial, o parlamento e dos partidos políticos em favor do executivo e da burocracia do Estado. Isso porque o novo papel do Estado o reestrutura via mecanismo da especialização de seus aparelhos e essa nova conformação informada agora pelo capital passa a ditar os limites do político e que, em última análise, expõe a tensão entre esse modelo de Estado e a política.

Assim, "O Estado pode cada vez menos calcar sua estratégia econômica sobre a política geral de organização da hegemonia. Ele deve tomar resoluções absolutamente essenciais então para a reprodução do capital, mesmo que isso crie graves problemas para sua hegemonia: essas disposições agudizam exatamente as contradições no seio do bloco no poder e entre este e as classes dominadas, e tornam-se um fator maior de crises que, por isso mesmo, ultrapassam a simples crise econômica." 124

Aliás, o distintivo do período quando se comparado ao século anterior é o advento do "estado de crise permanente" que transcende os aspectos meramente econômicos e que iria demandar a naturalização/banalização do "estado de exceção" e da necessidade de uma "ditadura constitucional permanente", cuja característica central é a "emergência virar regra" e o regime constitucional ser afastado não em seu aspecto formal, mas sim em sua realidade

\footnotetext{
${ }^{122}$ Poulantzas, Nicos. O Estado, o poder, o socialismo...Op. Cit., p. 190/198.

${ }^{123}$ Poulantzas, Nicos. Ibid, p. 194.

${ }^{124}$ Poulantzas, Nicos. Ibid, p. 193/194.
} 
fática, pois são derrogados os princípios democráticos enquanto método de tratamento dessa crise permanente. ${ }^{125}$

De acordo com Losurdo ${ }^{126}$, os liberais de forma uníssona iriam trabalhar a questão da democracia no curso do século XX não mais afeta a discussão em torno do direito de voto em si, tratava-se de agora em diante de teorizá-la na base de um elemento comum, qual seja: na busca de se obstar a associação entre o sufrágio universal e sistema representativo, com vistas a não só manter distante os direitos sociais e econômicos do catálogo de direitos, como também a impedir qualquer discussão sobre as bases estruturais da sociedade, logrando assim neutralizar o espaço social pela ratificação do status quo e, por conseguinte, aviltar "a soberania popular" em prol agora da "soberania do mercado". Aqui, retoma com força o desacoplamento entre o político e o econômico, questão esta que teve relevo já em Aristóteles ${ }^{127}$ quando tratou da classe média, e em Marx ao tratar da Questão Judaica que elenca os princípios do Estado burguês que cabem ser rememorados: i) declarar e legitimar, pela via dos direitos, uma situação real como natural; ii) apartar a vida civil da vida política; iii) outorgar ao social um caráter privado, tendo por reflexo o fato de que a sociedade, na base do individualismo e do interesse egoístico, fosse capaz de deslocar/manter o espaço público em um plano secundário, espaço esse que não ficaria vazio e seria assumido pela burocracia estatal.

Nessa série de considerações, são pertinentes as ponderações de Miliband quanto ao fracasso nas eleições dos partidos ditos sociais. A resposta do autor inicia-se com o retorno às reflexões advindas da Ideologia Alemã na qual a hegemonia das classes dominantes vale-se de meios outros para implementar seu consenso na sociedade. Consenso esse que, na verdade, é um processo velado de doutrinação das massas por meio dos quais os valores e símbolos capitalistas são introjectados, aceitos e vendidos como único caminho possível e que faz com que as críticas ao sistema voltem-se para apresentação de soluções que mascarem o real problema (social voltado ao lucro). ${ }^{128}$

\footnotetext{
${ }^{125}$ Bercovici, Gilberto. Soberania e Constituição...Op.Cit.,p.327/328.

${ }^{126}$ Losurdo, Domenico. Democracia ou Bonapartismo...Op. Cit., p.236/237.

127 O Móbil das revoluções está na ausência de igualdade proporcional, pois é sempre a desigualdade que ocasiona sedições, seja pela igualdade entre desiguais ou pela desigualdade entre iguais. Assim, Aristóteles procurou estabelecer a igualdade pela via justiça a partir de dois critérios: i) aritimetica/simples - numérica, ii) geométrica/proporcional - mérito. Afirmando que a constituição de um estado há de se basear na classe media vida mediana entre ricos e pobres onde todos podem alcançar em consonância com os ditames da razão, pois as fortunas medíocres e suficientes não sofrem sedições e, portanto, são mais propensas a estabilização e a durabilidade da própria constituição. A política...Op. Cit.., p.190/197.

${ }^{128}$ Miliband, Ralph. O Estado na sociedade capitalista. Trad. Fanny Tabak. Rio de Janeiro: Zahar editores, 1972, p. 221/222.
} 
Para além de questões ideológicas afetas ao Estado em si, ${ }^{129}$ tais como a passagem da ideologia religiosa à ideologia jurídico-político (cuja consequência leva a equiparação entre legitimidade e legalidade e a produção do isolamento, a partir da constituição de indivíduos enquanto sujeitos de direito livre e igual a transitar tanto no ambiente privado como no público), a racionalização formal do aparelho burocrático (que se apresenta no interesse geral da sociedade a partir de regras de hierarquia e de competência) e a apresentação dessa mesma ideologia jurídico-político enquanto ciência, mais especificamente, como técnica científica ausente de qualquer conotação de classe. Nesse momento, é relevante fazer menção a outras "agências de persuasão" empenhadas em uma "empresa de doutrinação conservadora". Nessa linha, Miliband ${ }^{130}$ aponta os próprios partidos conservadores, como "verdadeiras máquinas de propaganda" que fazem concessões às exigências populares desde que elas não questionem a estrutura de poder, cujo cerne é a propriedade em torno da qual gravitam os demais satélites: "liberdade, igualdade, democracia, patriotismo, interesse nacional, lei e ordem" e, tantos outros apetrechos da ideologia conservadora. Isso sem contar os recursos financeiros, a profissionalização da política (nas mãos da classe média sobretudo) e das campanhas eleitorais, fatores esses responsáveis por desequilibrar a disputa entre os partidos de direita e de esquerda, pendendo para aqueles.

Ainda no interior da política ${ }^{131}$, há que se fazer menção ao processo eleitoral em si, e mais precisamente, à questão do sufrágio universal e do voto secreto que se prestam, em alguma medida, a ratificar o apoio às elites tradicionais, e o mais relevante nessa seara é a ilusão da "igualdade de influência", na medida que essa igualdade formal legitima, na verdade, a "desigualdade de influência", uma vez que dissocia o cidadão da pessoa, dicotomia essa subtraída pela figura do indivíduo como sujeito de direito sob a ótica da universalidade, da abstração e da formalidade do sistema jurídico que em seu âmago ratifica a diferença e serve de fonte relevante à legitimação.

Isso sem contar que fatores outros ${ }^{132}$ corroboram para a hegemonia da classe dominante que são: i) o papel de desempenhado pelo empresariado que vende seu "ethos" e sua cultura, como modo de vida para além da mercadoria, atribuindo uma imagem positiva ao capitalismo, de modo a blindá-lo de questionamentos, por meio de mecanismos de publicidade: seja ela do tipo regular, pontual - "políticas privatistas”, ou então, auto-

\footnotetext{
${ }^{129}$ Poulantzas, Nicos. Poder político e classes sociais. Trad, Francisco Silva. São Paulo: Martins Fontes, 1977, p.207/212.

${ }^{130}$ Miliband, Ralph. O Estado na sociedade capitalista...Op. Cit., p. 225/235.

${ }^{131}$ Miliband, Ralph. Ibid, p. 236/237.

132 Miliband, Ralph. Ibid, p. 257/311.
} 
publicidade. Todas imbuídas do espírito de vender a empresa como uma atividade nobre, orientada ao social, com responsabilidade, voltada ao bem estar e à satisfação do consumidor; ii) meios de comunicação de massa que têm um papel relevante na manutenção do status quo e para doutrinação do clima de conformismo, seja pela via do escracho e do desdém com que tratam as concepções dissonantes do consenso ou então pela via do preconceito ou da censura privada de modo a tornar tais ideias inconsequentes ou excêntricas. Isso sem contar a questão da publicidade como um importante veio financeiro para alimentar a mídia escrita ou falada, pois são verdadeiras empresas capitalistas e a própria manipulação de informações pelo Estado, iii) meios de educação com papel funcional próximo ao daquele exercido pelos meios de comunicação e com atuação em três níveis: a) conformismo de classe nas crianças da classe operária na base do ideal da meritocracia; b) imposição de uma cultura de valores; c) valores de uma determinada sociedade e de mundo - moralidade democrática adaptada a fins conformistas; d) universidades - relação direta com o papel dos intelectuais na criação de ideias e valores. Esses apontamentos de per si retomam a Ideologia Alemã - os monopólios dos meios de produção material e intelectual permitem a autorreprodução do capitalismo com a naturalização do status quo até o ponto em que a própria família operária procura adaptar seus filhos a lógica do sistema. Nessa situação de "derrelicção do homem" ${ }^{133}$, ou seja, dele "jogado na existência", o passado toma lhe a frente, uma vez que a existência é temporal e é abalizada por acontecimentos reais e não por uma história transcendental, por isso é que a memória do passado projeta-se sobre o futuro, ela é viva e está a influir na historicidade do homem.

Em suma, os elementos acima arrolados objetivam dar uma amostra do processo de esvaziamento de qualquer tentativa à implementação da democracia, ${ }^{134}$ fazendo de vítima imediata os partidos políticos que em face da conjuntura modificam radicalmente sua atuação, passando de propositores de projetos políticos a verdadeiros "gestores e administradores" do

\footnotetext{
${ }^{133}$ Maman, Jeannette Antonios. Fenomenologia existencial do direito...Op. Cit.,p.54. No mesmo sentido, Marx afirma que a história do homem é transmitida pelo seu próprio passado e não é um ato de vontade. Marx, Karl. A revolução antes da revolução...Op Cit., p. 207.

${ }^{134}$ Rosenmann, Marcos Roitman. Os dilemas da democracia no Século XXI. Trad. José Argüello Franco. Rev. Universidade e Sociedade, Brasília, ano XII, no 28, nov/02, p. 19 e 25.

Leitura semelhante é realizada por Poulantzas que qualifica o quadro como "estatismo autoritário", distinto tanto do totalitarismo como das democracias do século XX, na medida em que a administração erige-se ao status de partido político num ambiente de hegemonia do capital monopolista. A operacionalização deste mecanismo é pela constituição de um "partido de estado dominante" que, ao mesmo tempo, tem a tarefa de controlar politicamente a administração pela sua unificação e homogeneização a partir de decisões tomadas pelo executivo, de servir de veiculo para a ideologia do estado e "apêndice de legitimação plebiscitária" da própria administração/executivo. Deixando, assim, margem de manobra reduzida aos partidos políticos, que para não serem extintos, findam por despersonalizem-se, ao se limitam ao debate em torno da política administrativa. Poulantzas, Nicos. O Estado, o poder, o socialismo...Op. Cit., p.269/279.
} 
Estado, visando à manutenção da ordem e da governabilidade, valores esses informados pelos critérios econômicos de eficiência e de racionalidade.

Todo o aparato montado tem por objetivo simplificar as complexidades sociais, exacerbar o individualismo e dissimular as contradições, de modo produzir um asceticismo na sociedade. Com isso, está-se a iludir a democracia pela construção de seu oposto - consenso político passivo - que se legitima em uma superfície de social, mas se que tem por trás de si a figura do Estado. ${ }^{135}$ A busca incessante para em um primeiro momento lograr o conformismo social e, posteriormente, o servilismo ao poder está em linha com a teorização da democracia moderna, ${ }^{136}$ enquanto procedimento eleitoral regulador da alternância de poder entre "partidos gestores" sob os auspícios da regra da maioria, abstraindo toda e qualquer perspectiva de futuro de mundo que a democracia poderia aspirar. Deste modo, a redução da democracia a seu básico - ao formal - permite ao econômico avançar sobre o político, transformando o Estado em uma empresa, tal como Weber já falara no começo do século XX.

\subsection{1) Weber - Um homem de nossos dias}

Com relação a Weber, o que nos interessa neste trabalho é o desenvolvimento de seu modelo teórico até o direito formal e, mais precisamente, ao sistema jurídico hodierno. Isso sem antes enunciar algumas das diferenças significativas para com Marx que, de plano, saltam aos olhos no que tangem à origem filosófica (neo-kantianismo e neo-hegelianismo) e as concepções políticas e de mundo (nacionalismo e socialismo, resignação e revolução). ${ }^{137}$ Tais diferenças fazem alusão aos influxos do método e do momento histórico, na medida que Weber se opõe à dialética (totalidade e identidade sujeito/objeto) pela especialização/racionalização das ciências, em razão da disposição a autonomização das

\footnotetext{
${ }^{135}$ Negri, Antonio; Hardt, Michael. O trabalho de Dioniso: para a crítica ao Estado pós-moderno. Trad. Marcello Lino. Juiz de Fora: Editora UFJF - Pazulin, 2004, p. 136.

${ }^{136}$ Rosenmann, Marcos Roitman. Os dilemas da democracia no século XXI...Op. Cit., p. 22, 23 e 26.

137Löwy, Michael. Figuras do marxismo weberiano. Disponível em: http://nplyriana.adv.br/artigos1/marxismo_weberiano.doc. Acessado em 29/12/07. Cabe aqui uma consideração para não desfigurar o texto de Lowy. O autor esboça um inventário de alguns importantes pensadores do século XX que buscam conjugar Marx e Weber, os assim chamados "weberos-marxismo", dentre os quais são citados Lucáks, a Escola de Frankfurt e Merleau-Ponty. Nesse mesmo texto, Lowy acena para um grupo de pensadores que acentuam as diferenças entre Marx e Weber dentre os quais menciona: Jean Marie Vincent, Lucien Goldman, Nicos Poulantzas, entre outros. Para os limites desta dissertação interessa justamente o contraponto entre Marx e Weber trazido pelo texto sem perquerir quanto à convergência entre tais pensadores dado que constituem um campo intelectual muito heterogêneo e, por conseguinte, tema para um estudo específico, o que na realidade essa dissertação não se propõe a fazê-lo.
} 
esferas culturais de valor, conduzindo a impossibilidade da restauração da razão objetiva pela dialética e que tem, por resultado, a não superação da reificação. ${ }^{138}$

Na obra Ética Protestante ${ }^{139}$, o contraponto weberiano ao materialismo histórico ${ }^{140}$, verifica-se com alguma ênfase, pois a relação entre economia e religião é causal, sendo esta informadora moral daquela. Assim, a conexão lógica inverte a posição materialista, na medida que a religião não poderia se situar mais na superestrutura. No fundo, o que Weber está fazendo é opor o espírito à relação antagônica entre capital e trabalho, visto que aquele é definido como a vinculação do indivíduo ao dever (trabalho), novo estilo de vida com base e consciência ética (valorização do trabalho), um fim absoluto em si mesmo, com o intuito de dar forma racional ao provimento de bens materiais necessários à humanidade.

A combinação sui generis entre positivismo e historicismo autoriza Weber a montar seu arcabouço assentado no imperativo categórico para o cientista - dicotomia entre fatos e valores e julgamentos e constatações, de modo que a tarefa das ciências ${ }^{141}$ limita-se a demonstrar "o modus operandi" do desenvolvimento dos fatores sociais em análise, escapando-lhe as respostas ao questionamento se elas devem ou não contribuir para este desenvolvimento. ${ }^{142}$

Nesse diapasão, Weber impinge limites ao racionalismo clássico ao afirmar que a ciência e a filosofia não são definidoras dos propósitos da sociedade humana, uma vez que a privatização da razão deixa a totalidade social e econômica à mercê de forças irracionais crises econômicas e líderes carismáticos. ${ }^{143}$ Por conseguinte, Weber constitui uma imagem contrastada da sociedade moderna dado que "os deuses antigos abandonam suas tumbas e, sob a forma de poderes impessoais, porque desencantados, esforçam-se por ganhar poder

\footnotetext{
${ }^{138}$ Nobre, Marcos. Lukács e os limites da reificação. Um estudo sobre história e consciência de classe. São Paulo: Editora 34, 2001, p.122/123.

${ }^{139}$ Weber, Max. A ética protestante e o espírito do capitalismo. Trad. Jose Marcos Mariani de Macedo. São Paulo: Companhia das Letras, 2004, p.59/61.

${ }^{140} \mathrm{O}$ núcleo do socialismo científico na medida em que os projetos de lutas sociais são concebidas a partir do sentido da ação no devir histórico tendo em vista a emancipação humana. Ou seja, a existência social do homem é determinante para sua consciência, e não por formulações de mundo criadas a base de instituições ou da moral que repousam sobre princípios absolutos. Introdução de Gorender, Jacob. (In) Marx, Karl; Engels, Friedrich. A ideologia alemã. Trad. Luis Cláudio de Castro e Costa. $3^{a}$ ed. São Paulo: Martins Fontes, 2007, p.xxv/xxviii.

${ }^{141}$ Weber engendra a cisão total entre política e ciência ao rejeitar soluções cientificas para questões das ciências políticas, economia política, sociologia e história, dado que "a ciência não é produto da revelação, não é parte integrante da mente de sábios e filósofos que se dedicam a refletir sobre o sentido do mundo. Tal é o dado inelutável de nossa situação histórica...que se caracteriza pela racionalização, pela intelectualização e, sobretudo, pelo desencantamento do mundo levou os homens a banirem da vida pública os valores supremos e sublimes." Weber, Max. Ciência e política. Duas vocações. Trad. Leônidas Hegenberg e Octany Silveira da Mota. $3^{\text {a }}$ ed. São Paulo: Cultrix, 1967, p.38/47 e 51.

${ }^{142}$ Löwy, Michael. As aventuras de Karl Marx contra o Barão de Munchhausen...Op.Cit., p.39.

${ }^{143}$ Löwy, Michael. Figuras do marxismo weberiano...Op. Cit.
} 
sobre nossas vidas, reiniciando suas lutas eternas. Daí, os tormentos do homem moderno...". 144

Em Weber, um tema essencial é a ruptura da unidade da razão ${ }^{145}$ (substancial orientada a valores e funcional - orientada a fins), que isola a lógica econômica da vida social e política, pela criação de um espaço autônomo de ação para os agentes do desenvolvimento econômico. ${ }^{146}$ Sua análise volta-se à descrição do processo histórico de evolução do conhecimento científico com redução da esfera de influência das culturas que deságua em uma visão de mundo informada pela racionalidade instrumental, alijada de qualquer ideia de desenvolvimento, de sentido de mundo o que irá redundar no individualismo metodológico. Weber é um critico da modernidade iluminista, na medida que ela lançou o homem no vácuo, afastando-o de Deus e dos preceitos morais, deixando-lhe apenas a noção de utilidade social.

Toda a trajetória da modernidade é ilustrada por Weber na passagem do ascetismo fora do mundo por um ascetismo dentro do mundo - separação do mundo do fenômeno do mundo do ser, substituição dos profetas por juristas e administradores que levam a modificação com relação ao sentido do mundo e a ação no mundo, via eliminação do finalismo das religiões, da revelação e da ideia de sujeito e a substituição pelo desencantamento, secularização, racionalização, autoridade racional legal e ética da responsabilidade. ${ }^{147}$

Passados por alguns dos pressupostos do pensamento weberiano, faz-se mister estudar a questão do Estado moderno e, mais especificamente, o direito formal. Nessa lógica, um texto chave a respeito do Estado é a Política como Vocação, onde Weber delineia o funcionamento do Estado a partir de seu conceito - "o monopólio do instrumento da violência legitima de que dispõem os agrupamentos humanos para a realização da dominação do homem sobre o homem". 148

No fundo, o que Weber está a fazer é aproximar a definição de Estado a de política pelo poder, escorado em tipos diversos de autoridade/dominação, cuja legitimidade no âmbito do Estado moderno reside no direito, ou melhor, na "crença na validade de um estatuto legal

\footnotetext{
${ }^{144}$ Weber, Max. Ciência e Política...Op. Cit., p.42/43.

145 Tal assunto é ilustrado na relação entre espírito do capitalismo e o próprio capitalismo, se num primeiro momento o espírito prevalece como ordem informadora da visão de mundo avalizada pela religião, logo em seguida, o sistema capitalista se desprende do espírito, tornando-se uma mera vocação para ganhar dinheiro, independente dos fins, e formulando uma nova visão de mundo centrada agora em interesses (político, econômico e social). Weber, Max. A ética protestante e o espírito do capitalismo...Op.Cit., p.62 e 83.

146 Touraine, Alain. A Crítica da modernidade...Op.Cit.,p.35.

${ }^{147}$ Touraine, Alain. Ibid, p.38.

${ }^{148}$ Weber, Max. Ciência e política...Op. Cit., p.56.
} 
e de uma competência positiva fundada em regras racionalmente estabelecidas". ${ }^{149}$ Ou seja, Weber refuta as concepções normativas em prol de uma leitura fenomenológica da sociedade ao definir o Estado pelo meio e não pelo fim de modo que o elemento presente em todo tipo de Estado é a coerção como última ratio da estabilidade e da conservação do poder político. ${ }^{150}$

A particularidade do Estado moderno/burocrático encontra-se na lógica racional fomentada pela diferenciação funcional e especialização das organizações administrativas, de modo a autorizar e a manter a segmentação entre a administração e a política ${ }^{151}$. A primeira governada por critérios técnicos, por princípios da divisão do trabalho e pela existência de funcionários de carreira para execução de ordens; a segunda dirigida pela luta, paixão, combate e vinculada à ética, porquanto a política influencia a vida das pessoas, afastando-se da realidade quotidiana.

Weber afirma que a conexão entre ética e política é anterior à modernidade, na medida que as religiões depararam-se com tais questões que se atrelam a modelos de Estado e ao fenômeno histórico da passagem da revolução à tradição. ${ }^{152}$ Assim, tal como fizera com a economia (espírito), Weber estabelece a relação entre religião e vocação política, com a peculiaridade de que cada uma é movida por leis especificas - a economia para o fornecimento de bens materiais e a política para o poder. Destarte, a vocação política abarca tanto a ética da convicção (ação) como a da responsabilidade (resultado) que, no fundo refletem a tensão entre meios e fins. Aqui, Weber ampara-se em Maquiavel, um dos primeiros a trabalhar a passagem do divino para a política, como expressão do sagrado na vida social, expondo o conflito na célebre citação - "eles preferiram a grandeza da cidade à salvação de suas almas". 153

O processo de secularização do direito segue em linha com a sociologia weberiana (tipos - dominação), partindo do direito religioso, passando pelo direito natural e chegando ao positivismo jurídico ${ }^{154}$. Weber trabalha o direito como categoria básica do acontecer social pela simbiose das forças racionais (política e economia), cuja centralidade reside naquela,

\footnotetext{
${ }^{149}$ Weber, Max. Ciência e política...Op. Cit., p.57.

150 Diniz, Antônio Carlos de Almeida. Teoria da legitimidade do direito e do Estado: uma abordagem moderna e pós-moderna. São Paulo: Landy editora, 2006, p.115 e 118.

${ }^{151}$ Prefácio de Berlinck, Manoel. T. (In) Weber, Max. Ciência e política...Op. Cit., p.12.

152 Protestantismo valeu-se da violência como instituição divina. Para Calvino, a força é o meio legitimo para a defesa da fé, assim, se legitima as guerras de religião. Weber, Max. Ciência e política...Op. Cit., p.118.

${ }^{153}$ Weber, Max. Ibid, p.121.

154 Direito natural foi o instrumento de eleição das classes revolucionaria enquanto forma legitimadora das revoluções dos séculos XVIII e XIX, caracterizado pela ausência de elementos religiosos e da arbitrariedade da promulgação, fundando no caráter compromissário de numerosas disposições de cunho axiomático, independente de qualquer direito positivo. Weber, Max. Economia e sociedade: fundamentos da sociologia compreensiva. V. II. Trad. Regis Barbosa e Karen Elsabe Barbosa. São Paulo: imprensa oficial do Estado de São Paulo, 2004, p.134.
} 
porquanto a política representa o monopólio oficial da criação do direito por parte de associações políticas modernas (instituições) e indiretamente condicionadas pela economia e por fatores técnico-juridicos. ${ }^{155}$

A economia informa o direito pela ideia de calculabilidade e segurança e, ao mesmo tempo, é fonte de novas situações que serão engendradas pelas invenções técnico-juridicas e, posteriormente, postas a serviço dos interesses econômicos. Os fatores técnico-juridicos e, mais precisamente, a atuação dos intelectuais conduzem a tarefa de sistematização e interpretação lógico-racional das normas jurídicas, cuja vigência é reconhecida em um sistema internamente consistente de disposições jurídicas abstratas que resultam na racionalidade formal. Esta racionalidade possibilita ao sistema jurídico atuar como uma máquina $^{156}$ estabelecendo as regras do jogo a fim de informar o estado ótimo de calculabilidade aos interessados no que confere as ações referentes aos fins. No fundo, a justiça formal é um excelente negócio para a burguesia na medida que mitiga os efeitos do arbítrio e da subjetividade dos agentes.

Por fim, os profissionais assumem um papel relevante na superação do direito natural pelo positivismo, conjugando ideias a interesses. Eles dissociam o jurídico de qualquer outro fenômeno social pela construção de um ponto de vista particular e irracional a qualquer outro sistema, estabelecendo a legalidade como critério de pertinência e de validade do sistema cujos limites são informados pelo mínimo ético (justiça e dignidade humana) retirado do direito natural. ${ }^{157} \mathrm{O}$ positivismo, ${ }^{158}$ para além da superação dos princípios da filosofia do jusnaturalismo, permite ao Estado pelas mãos da burguesia, estatuir o direito em consonância com "a dinâmica de auto-reprodução do capitalismo" equiparando, economia e direito alheio a qualquer conotação política, porquanto esta cedeu espaço à razão-técnica. Ou melhor, a "autonomia técnica do Estado" associada à "neutralização da política" legitima o "domínio econômico".

\subsection{2) Aspectos de três momentos relevantes do século XX}

\subsubsection{1) Weimar}

\footnotetext{
${ }^{155}$ Weber, Max. Economia e sociedade. V.II....Op. Cit., p. 11.

${ }^{156}$ Weber, Max. Ibid, p.103.

${ }^{157} \mathrm{O}$ direito natural material é destruído pelo positivismo relativista - evolucionista dos intelectuais socialistas (marxistas) e pelo positivismo comteano. Então, os axiomas do direito natural perdem a força para servir do fundamento ao direito (dignidade meta-jurídica, supra-empírica) em vez disso tem-se o positivismo jurídico (concepção ideológica). Positivismo jurídico é fruto, também, do papel dos juristas e advogados, pois escolheram o lado da ordem (dominantes - legítimos e autoritários). Weber, Max. Ibid, p.140.

${ }^{158}$ Mascaro, Alysson Leandro. Para uma crítica da legalidade no Brasil contemporâneo...Op. Cit., p.24 e 112.
} 
Este tópico não tem com intuito retomar a complexidade da Alemanha do entre guerras nem descrever a Constituição de Weimar que, em conjunto com a Constituição mexicana de 1917, simbolizam o constitucionalismo social, cuja marca mais visível são os direitos sociais, direitos esses de prestação intimamente ligados à presença do Estado na ordem econômica e social. O que, na verdade, interessa extrair de Weimar para os limites desta dissertação é sua atualidade tão bem descrita por Bercovici, apoiada em duas concepções diametralmente opostas - a de Schmitt e a de Heller, visões essas que ecoam nos dias atuais, sobretudo, quando se pensa na realidade dos Estados periféricos do capitalismo.

Bercovici $^{159}$ apregoa a atualidade do pensamento de Schmitt nos domínios do neoliberalismo e, em especial, nos Estados periféricos que vivem sob "a exceção econômica permanente" em oposição à normalidade do centro, na medida que há uma subordinação quase absoluta desses Estados ao mercado, ensejando o "decisionismo de emergência", a fim de privilegiar os interesses do capital em detrimento do povo. Esse mecanismo é perpetrado com a liberalização radical da economia e com a não liberalização política, ou melhor, ele combina "despolitização radical das relações econômicas" e "redução da vida democrática ao mínimo necessário" ao ponto da democracia política nos países da América Latina poder se tornar um "simulacro eleitoral", o que, em alguma medida, remonta as teses de Schmitt.

O conteúdo do parágrafo anterior será trabalhado com maior detalhes nos dois próximos tópicos, bem como no capítulo III desta dissertação. Por ora, cabem algumas considerações quanto ao que seria o Estado total de Schmitt e seu contraponto o Estado Social de Heller e, para tanto há de se voltar para o interior de Weimar, ${ }^{160}$ cujo debate é pautado, dentre as inúmeras propostas que ali floresceram, por estas duas concepções antagônicas, que põem frente a frente socialismo e liberalismo enquanto maneiras de suplantar o Estado liberal do século XIX. A primeira, na perspectiva dita reformista, tendo como mentor Hermann Heller e que tem no Estado social de direito a via de passagem sem rupturas a nova ordem socialista -, bem como sua posterior manutenção, de forma que a constituição seria o instrumento para a promoção da justiça social; a segunda, no viés dito conservador, cujo artífice é Carl Schmitt e que se fundamenta em torno do Estado total com o fim da celeuma divisória entre Estado e sociedade e, por conseguinte, entre Estado e economia, uma vez que o Estado perde o monopólio político e associa-se à economia (livre).

\footnotetext{
${ }^{159}$ Bercovici, Gilberto. Constituição e estado de exceção permanente. Rio de Janeiro: Azougue Editorial, 2004, p. 171/180.

${ }^{160}$ Bercovici, Gilberto. Ibid, p.21/23.
} 
Em linhas gerais, o primeiro modelo ${ }^{161}$ - Estado Social de Direito - tem sua marca no primado do político frente ao econômico, de modo que o Estado deva ser compreendido com base na realidade social, dentro da qual o econômico é apenas um momento, diga-se de passagem, relevante. O Estado, segundo Heller, seria a alavanca para o socialismo, depositando esperanças na democracia política, ação consciente dos atores orientada para um fim determinado, como meio para se chegar à democracia econômica, caracterizada pela distribuição de poder e de riqueza, visto vez que os interesses privados estariam submetidos aos interesses sociais. O socialismo, para o autor, a despeito da concepção de Marx e Engels, significaria não mais a destruição e sim a transformação, o refinamento do Estado, na medida que apregoava a passagem da justiça jurídico-formal, democracia burguesa, à justiça econômico-material - democracia socialista - bem como a impossibilidade da manutenção da estrutura de classes.

Heller atribuía ao Estado Liberal o advento da democracia formal como forma de combate aos estamentos políticos; democracia essa que cindia os poderes econômico e político e possibilitava que os trabalhadores, pela via democrática, assegurassem o predomínio da vontade popular em face do econômico privado no interior do Estado. Isso se daria por meio de um Estado forte que se valesse de uma sólida base econômica, a fim de se contrapor ao poder econômico privado e derrogar, desse modo, as classes econômicas. Nessa trajetória de aprimoramento da democracia - formal para substancial - Heller via na Constituição de Weimar um excelente instrumento para modificação do status, pois seu grande mérito é ter deixado "aberta às forças sociais vivas as válvulas jurídicas que permitem a supressão, pela democracia, das contradições sociais." 162

Uma leitura distinta da de Heller é aquela de Schmitt ${ }^{163}$ que via a crise do Estado burguês do século XIX como sendo um eco da falência da estrutura do liberalismo clássico na medida que esse liberalismo não conseguia integrar as massas na unidade política (nesse Estado liberal de direito) o que facilitava, em última análise, a perda do monopólio do político (política essa entendida pelo autor como a capacidade que um Estado tem de fazer a distinção entre amigo e inimigo com vista a manter a pacificação completa dentro de um território). $\mathrm{O}$ avanço e a consolidação da democracia liberal levavam a transformação do parlamento em um local de não mais de decisão política e sim de disputa pelo poder do Estado o que, em última análise, era deletéria para a própria unidade política. Assim, "quando o Estado se

\footnotetext{
${ }^{161}$ Bercovici, Gilberto. Constituição e estado de exceção...Op. Cit., p.109/138.

${ }^{162}$ Bercovici, Gilberto. Ibid, p.136.

${ }^{163}$ Bercovici, Gilberto. Ibid, p. 77/107.
} 
transforma em estrutura pluralista não há mais fidelidade ao Estado ou à Constituição, mas fidelidade a organização social, colocando em risco a formação da unidade política". ${ }^{164}$

Para Schmitt, o advento do Estado total representava a evolução do próprio Estado no ínterim da ordem capitalista a partir das distintas unificações: a religiosa, a nacional e a econômica. Esse Estado total significava a "politização de tudo" e tinha como caráter distintivo o fim da separação entre Estado e sociedade, a partir daí todos os problemas econômicos e sociais passariam a ser estatais. Schmitt ainda afirmava que a Constituição de Weimar mostrava-se como uma não solução para o advento do Estado Total, conforme ali se estatuía um Estado total do "tipo quantitativo" no sentido de ser um Estado Social pautado no pluralismo partidário o que derrogava, em última instância, o monopólio do político do Estado.

A solução para o impasse alemão do entre guerras, segundo o autor, estava no advento do Estado total de outro tipo - o qualitativo - o que impunha a revogação de Weimar. As vicissitudes do Estado legislativo somente seriam aplacadas por um Estado forte e neutro. Forte no sentido de ser capaz de impor sua vontade política na base relacional do amigo/inimigo e neutro no sentido de ser o garante de uma economia liberal. Sendo assim, o Estado total de Schmitt dirige-se contra o Estado de partidos políticos, objetivando não só a remoção de qualquer conotação política (de cunho partidário) da esfera econômica, arrefecendo, assim, qualquer conflito existente nessa seara, como também a superação da democracia parlamentar por outra - a plebiscitária, outorgando um poder descomunal e uma independência que o presidente necessitava em face dos partidos.

A conjugação de liberalismo econômico e não liberalismo político é capital para Schmitt na medida em que "só um Estado forte pode se retirar das esferas não estatais. $O$ Estado neutro é um Estado forte, pois separa o Estado da economia e da sociedade civil. A neutralização e a despolitização da economia (que são processos políticos, pois só podem se originar da decisão política do Estado) necessitam de um Estado com liderança política, que só é capaz de existir se possuir fundamentos plebicitários. Schmitt não se opõe ao livre mercado, mas entende que este só pode sobreviver sob a égide deste Estado forte". ${ }^{165}$ As teses de Schmitt, conforme veremos a seguir, são muito atuais para o contexto presente e vêm em linha com a ideia central do capítulo que é mostrar a incompatibilidade entre democracia e liberalismo nos domínios dos direitos sociais.

\footnotetext{
${ }^{164}$ Bercovici, Gilberto. Constituição e estado de exceção...Op. Cit., p.82.

165 Bercovici, Gilberto. Ibid, p.101/102.
} 


\subsubsection{2) Pós-Guerra - Welfare State}

Pode-se dizer que este foi um ponto fora da curva na história do capitalismo, na qual a democracia atingiu seu ápice pela via do reconhecimento objetivo dos direitos sociais expressos nas Constituições à época e que pela ampliação de sua esfera material consagrou o Estado social e a vitória efêmera da soberania popular. Todavia, a formalização da democracia substancial não é sinônimo de sua concretização e, na prática, o que se verificou foi "a suspensão do seu núcleo emancipatório". ${ }^{166}$ Tal é a amostra do padrão da disputa entre classes sociais, pois se, nesse momento histórico, a burguesia, para salvar o sistema capitalista, empenhou os anéis que aqui atendem pelo nome de direitos sociais; no momento subsequente, da reconquista da hegemonia, a burguesia os quer de volta, voltando-se, virulentamente, aos ganhos sociais.

Basicamente, o modelo do Welfare State encerra em si a dialética do Estado quando de sua legitimação na relação Capital e Trabalho, pois se de um lado o setor público arca com os custos da produção para atender aos anseios do Capital; de outro lado, esse mesmo setor concede benefícios sociais para a classe trabalhadora. Desse modo, o Estado nutre o circulo vicioso dos grupos de interesse pautados no binômio (necessidade e pressão), cujas consequências dessa presença são percebidas nos recorrentes déficits fiscais do Estado para manutenção do pacto Keynesiano, mas essa contradição recrudesceu a partir da década de $1970^{167}$, rompendo com o circulo virtuoso de crescimento do pós 1945.

Nesse contexto, verifica-se que a crise do Welfare State tem origem na sua própria estrutura, pondo em cheque o padrão de desenvolvimento capitalista, em virtude do esgotamento dos mecanismos de expansão do crescimento econômico, da ampliação da capacidade ociosa do setor produtivo e, por conseguinte, do redirecionamento do investimento produtivo para o capital financeiro associado, ainda, ao déficit das finanças públicas e a aceleração da inflação.

Nessa linha, Belluzzo e Coutinho, discorrendo sobre as causas imediatas e as raízes estruturais dessa crise, afirmam que sua especificidade transcende as soluções baseadas nas clássicas políticas fiscais e monetárias, pois ela é o resultado da conjugação de dois fatores, a

\footnotetext{
${ }^{166}$ Bercovici, Gilberto. Soberania e Constituição...Op.Cit., p.321.

${ }^{167}$ Outros dois fatos devem ser considerados para traçar o panorama à época, são eles: o fim da conversibilidade dólar-ouro estabelecida nos Acordos de Bretton - Woods que conduziram a expansão dos limites monetários e, por conseguinte, do credito e a crise do petróleo de 1973 que alterou a estrutura de custos das empresas. Prado, Antonio. A controvérsia da crise do fordismo e a transição pós-fordista: algumas reflexões sobre o caso brasileiro. In: Paulo: Dieese, $\overline{1999, \text { p.20. }}$

Emprego e desenvolvimento tecnológico: processos de integração regional. São
} 
saber: de um lado, tem-se um processo de superacumulação com esgotamento de um determinado padrão tecnológico; de outro, verifica-se a exaustão da forma de ampliação e de crescimento desse padrão produtivo, operado pela grande empresa via internacionalização do capital industrial em escala global. "Como fenômeno colateral importante, devemos assinalar a gestação progressiva, durante este ciclo de internacionalização, de um circuito financeiro internacional alimentado por excedentes de capital não imediatamente utilizáveis na esfera produtiva. Este fenômeno vai-se tornando cada vez mais importante à medida que o ciclo de internacionalização das empresas começa a atingir seu ponto de saturação em vários setores. O surgimento desse circuito financeiro, de caráter inequivocamente transnacional, pode ser detectado pela intensa internacionalização do grande capital bancário, notadamente do norte-americano". 168

O quadro acima representa o impasse a que foi levado o Estado de Bem Estar Social $^{169}$, e uma das possíveis soluções, acatada, em geral, pela comunidade internacional propugnava pelo retorno aos ideários liberais com a introdução da disciplina orçamentária, com o controle de gastos sociais, desregulamentação dos mercados domésticos, submissão das empresas à concorrência global, eliminação das barreiras alfandegárias, flexibilização dos mercados de trabalho para superar os regimes inflacionários e a revigorar o curso normal da acumulação no sistema capitalista ${ }^{170}$. Ou melhor, todo o problema foi posto sob o argumento

168 Belluzo, Luiz Gonzaga de Mello; Coutinho, Luciano. O desenvolvimento do capitalismo avançado e a reorganização da economia mundial no pós- guerra. IN: Estudos Cebrap, $\mathbf{n}^{\circ}$ 23, São Paulo, 1981.Disponívelem:http://www.cebrap.org.br/imagens/Arquivos/o_desenvolvimento_do_capitalismo_avancado. pdf. Acessado em 05/07/07.

${ }^{169}$ Nos países em desenvolvimento que jamais lograram o Estado de Bem Estar, a magnitude dos efeitos do processo da globalização podem, assim, serem descritos: "Os processos vinculados a mundialização do capital em um quadro de integração subalterna, podem ter fortes conseqüências econômico-sociais no Brasil, dado o grau de internacionalização da economia nacional e de vulnerabilidade a fatores desestabilizadores externos (Gonçalves, 1994). A vulnerabilidade externa tem se manifestado de forma marcante no crescimento do endividamento e nos elevados déficits nas transações correntes do balanço de pagamentos. Há uma deterioração da estrutura do comércio exterior, com aumento do peso das exportações de bens baseados em recursos naturais e energia abundante e ampliação das importações de maior conteúdo tecnológico. Além do mais, ocorreu um intenso processo de desnacionalização da economia brasileira ao longo da segunda metade dos anos 90, de sorte que o capital estrangeiro passou a exercer um controle direto de pelo menos $15 \%$ da economia. $O$ poder estratégico das empresas estrangeiras manifesta-se no predomínio em importantes segmentos que são intensivos em tecnologia e possuem estruturas oligopólicas. Parcelas crescentes da produção e da renda interna são controladas por não-residentes (Gonçalves, 1999). O investimento direto de capital estrangeiro tem se dirigido nos últimos anos sobretudo à compra de empresas públicas (privatização) e privadas (baixo valor). O processo de privatização dos serviços públicos contribuiu para que o setor de serviços passasse a concentrar $80 \%$ do estoque de capital externo investido no país (Mattoso, 1999:26-28)."”

Santos, José Alcides Figueiredo. Mudanças na estrutura de posições e segmentos de classe no Brasil. Dados, Rio de Janeiro, v.44, n.1, 2001. Disponível em: http://www.scielo.br/scielo.php?script=sci_arttext\&pid=S001152582001000100005\&lng=pt\&nrm=iso. Acessado em 04/07/07.

${ }^{170}$ Grau, Eros Roberto. A ordem econômica na Constituição de 1988...Op. Cit., p.49.

Os remédios empregados seguem três grandes linhas: todas elas buscando a retomada do desenvolvimento econômico pela via da abertura do comércio, da estabilização da moeda e da eliminação dos déficits do estado i) desestatização - a empresa publica não mais como instrumento de desenvolvimento econômico de um pais; ii) 
de que o Estado fora responsável pelo arrefecimento da atividade econômica, dada sua inabilidade ao tratar com a nova conjuntura, decorrente do desenvolvimento tecnológico e industrial, bem como da consequente, expansão do desemprego; dando, assim, guarida a soluções de cunho liberal-mercantil.

Aqui reside o cerne da questão que contrapõe de um lado mercado e de outro os trabalhadores em um ambiente de alteração da correlação das forças institucionais do capitalismo - Estado, empresas e mercado, sob o primado, agora, do último ${ }^{171}$. Esse movimento de centralização do capital em escala mundial trouxe como consequências a reorganização estrutural da empresa capitalista com redução de custos e dos níveis de emprego, com o alargamento das fusões e aquisições em todos os setores e uma mobilidade inimaginável de capitais entre as praças financeiras mundiais, com prejuízos significativos aos direitos sociais angariados pelos trabalhadores nas últimas décadas.

A globalização ${ }^{172}$ modificou em grande medida o padrão de acumulação capitalista, dada a proeminência do setor financeiro na direção dos mecanismos de regulação e de reprodução da riqueza social, por intermédio da taxas de juros e dos lucros não financeiros. Este intróito se faz necessário para pontuar o quanto o processo de globalização vem alterando a estrutura capitalista na medida que hoje se verifica a lógica capitalista centrada na concentração do capital financeiro em escala global, na dominação dos fluxos de informação e na rentabilidade dos ativos ${ }^{173}$.

desregulamentação que opõe eficiência do mercado versus o burocratismo do estado; iii) desuniversalização reversão de padrões universais de proteção social. Fernandes, Luis. Neoliberalismo e reestruturação capitalista. In: Sader, Emir; Gentili, Pablo (org). Pós-Neoliberalismo...Op. Cit., p.55/56.

${ }^{171} \mathrm{Na}$ segunda metade do século XX, assistiu-se a transformações estruturais do capitalismo que conjugou três fatores: a chegada do processo de industrialização na esfera dos serviços (primeiro o privado, depois o público); produção flexível - responsável em grande parte pela modificação das relações de força e de poder entre empresas individuais e o mercado; expansão dos mercados financeiros internacionais. Fatores esses que alteraram o arcabouço institucional do capitalismo pela passagem do primado do Estado para o mercado. Therborn, Goran. A crise e o futuro do capitalismo. (In) Sader, Emir; Gentili, Pablo (org). PósNeoliberalismo...Op. Cit., p.40/46.

172 "Este sistema doutrinário é também conhecido como Consenso de Washington, que é um conjunto de princípios de reordenamento dos mercados desenhado pelo governo americano e pelas instituições financeiras multilaterais as quais controla, como o Fundo Monetário Internacional (FMI) e o Banco Mundial. Druck (1999) argumenta que o Consenso de Washington ganhou este nome a partir de expressão cunhada pelo economista John Williamson do Institute for International Economics e ...pode ser resumido em três objetivos principais: a) estabilização da economia (corte no déficit público, combate à inflação), em geral, tendo por elemento central um processo, explícito ou não, de dolarização da economia e sobrevalorização das moedas nacionais; b) reformas estruturais com redução do Estado, através de um programa de privatizações, desregulação dos mercados e liberalização financeira e comercial; $c$ ) abertura da economia para atrair investimentos internacionais e retomada do crescimento econômico". Siqueira, Carlos Eduardo; Castro, Hermano; Araújo, Tânia Maria de; A globalização dos movimentos sociais: resposta social à globalização corporativa neoliberal. Ciência \& Saúde Coletiva, Rio de Janeiro, v.8, n.4, 2003. Disponível em: http://www.scielo.br/scielo.php?script=sci_arttext\&pid=S1413-81232003000400002\&lng=pt\&nrm=iso. Acessado em 03/07/07.

${ }^{173}$ Grau, Eros Roberto. A ordem econômica na Constituição de 1988...Op. Cit., p.52. 
Para os limites deste trabalho, a globalização traz duas questões relevantes, uma versa sobre a relação entre Estado e capital financeiro; a outra diz respeito à mudança do ciclo produtivo. A questão da financeirização e do Estado por fins didáticos será tratada em outro capítulo; por ora, o trabalho dirige-se ao tema atinente à reestruturação do ciclo do capital produtivo que culminou com a substituição, em grande parte, do Fordismo pelo Toyotismo. O modelo assenta-se em larga medida na utilização da tecnologia de informação, no estabelecimento de novos sistemas de gestão empresarial (metas de desempenho, ganhos de produtividade, estoques mínimos, dentre outros), no processo de terceirização e, por conseguinte, no achatamento vertical das empresas.

O Toyotismo acarreta a redução quantitativa do emprego (desemprego estrutural) e a alteração qualitativa do trabalho (modo de ser do trabalho) com a tendência para maior qualificação de alguns ramos produtivos e desqualificação de outros setores. No que confere a intelectualização do trabalho, denota-se que a tecnologia e o conhecimento científico empregados na atividade produtiva modificam aquilo que ficou designado como um dos fatores da produção - o tempo de trabalho, reduzindo-o na forma necessária para ampliá-lo na forma excedente. Logo, o tempo de trabalho como valor de troca deixa de ser a medida do valor de uso na cadeia produtiva, ou seja, a criação de riqueza busca se desvencilhar do tempo de trabalho nela empregado. ${ }^{174}$

Com relação à desqualificação do trabalho, esta se revela na desespecialização de segmentos do operariado fordista em decorrência do surgimento de "trabalhadores multifuncionais", o que os direcionou ao processo de precarização do emprego (subcontratação, terceirização, dentre outras), bem como na entrada da economia informal Ricardo Antunes ${ }^{175}$ é lapidar para caracterizar esse segmento de trabalho: "A periferia da força de trabalho compreende dois subgrupos diferenciados: o primeiro consiste em empregados em tempo integral com habilidades facilmente disponíveis no mercado de trabalho (...) Esse subgrupo tende a se caracterizar por uma alta rotatividade no trabalho. $O$ segundo grupo situado na periferia oferece uma flexibilidade numérica ainda maior e inclui empregados em tempo parcial, empregados causais, pessoal com contrato por tempo determinado, tendo ainda menos segurança de emprego do que o primeiro grupo periférico."

Deste modo, a alteração do padrão de produção repercute sobre o mercado de trabalho e, em especial, em suas formas tradicionais de contratação, uso, remuneração e

\footnotetext{
${ }^{174}$ Antunes, Ricardo. Adeus ao trabalho? Ensaios sobre as metamorfoses e a centralidade do mundo do trabalho. $2^{a}$ ed. Campinas: Cortez, 1995, p.47/49.

${ }^{175}$ Ibid, p.53.
} 
dispensa da força de trabalho em virtude da: i) expansão do desemprego, ii) subutilização da força de trabalho, iii)aumento do autoemprego, como alternativa ou necessidade ao contingente de desempregados ${ }^{176}$.

A estrutura toyotista exacerba o valor do indivíduo em detrimento da noção do coletivo no trabalho, uma vez que a realidade contraditória e ambivalente do desemprego estrutural se faz sentir presente nas órbitas social e psicológica e têm como implicação direta o desenvolvimento de reações de reserva e de insensibilidade quanto ao semelhante, bem como no abrandamento das reações de solidariedade de mobilização coletiva ${ }^{177}$. Em outros termos, a lógica do individualismo da ação inerente ao toyotismo predomina sobre a lógica da ação coletiva inerente ao fordismo e, por conseguinte, ao sindicalismo, obstando de forma irretorquível a ação coletiva.

A crise objetiva e subjetiva do mundo do emprego trouxe reflexos profundos na estrutura do sindicalismo. Os sindicatos como resposta ao novo regime de acumulação flexível $^{178}$ assumiram posturas defensivas, distanciando-se da ideia de centro de organização de classe $^{179}$ pelas seguintes ações perpetradas: i) o sindicalismo buscou se fechar sobre si, a fim de se preservar como corporação burocrática, acentuando o viés corporativo (instinto de autopreservação); ii) adoção de sindicalismo de empresa (redução da abrangência e conteúdo das convenções coletivas e descentralização das negociações coletivas) e da cultura de consertação social na seara da cooperação e da participação com o próprio capital. Logo, a nova práxis sindical ${ }^{180}$ vai ao encontro da lógica do mercado, inaugurada pelas novas disposições do toyotismo.

\footnotetext{
176“'Ao longo do tempo, vem se agravando a heterogeneidade e a fragmentação da estrutura ocupacional brasileira. Impera no país uma elevada flexibilidade salarial, entendida como a flutuação dos salários em função da variação do nível de atividade econômica (Barros e Mendonça, 1996). Longe de funcionar como esfera excessivamente regulada, o mercado de trabalho brasileiro apresenta igualmente uma flexibilidade alocativa - capacidade de ajustar-se aos choques mediante a realocação da mão-de-obra - superior à encontrada nos países industrializados (Barros et alii, 1999)." Santos, José Alcides Figueiredo. Mudanças na estrutura de posições e segmentos de classe no Brasil...Op. Cit.

177 Dejours, Christophe. A banalização da injustiça social. Trad. Luiz Alberto Monjardim.Rio de Janeiro: Fundação Getúlio Vargas, 1999, p.23 e 24.

178 Alves, Giovanni. Trabalho e sindicalismo no Brasil dos anos 2000. Dilemas da era liberal. In: Antunes, Ricardo (org). Riqueza e miséria do trabalho no Brasil. São Paulo: Boitempo, 2006, p.468.

179 Alves, Giovanni. Trabalho e sindicalismo no Brasil dos anos 2000. Dilemas da era liberal. In: Antunes, Ricardo (org). Riqueza e miséria do trabalho no Brasil...Op. Cit. p.464.

${ }^{180} \mathrm{Na}$ mesma linha do diagnóstico traçado acima, Elísio Estanque assevera que "Uma tendência alarmante que, por isso mesmo, desencadeou na última década novas políticas de alianças por parte do sindicato, levando-o a reorientar a sua intervenção para o plano transnacional, procurando contrapor ao localismo de exclusão o sentido globalista, inclusivo e cosmopolita, que tenta combater as opressões locais a partir das solidariedades globais." A reinvenção do sindicalismo e os novos desafios emancipatórios: Do despotismo local à mobilização global. In: Santos, Boaventura de Sousa (org.). Trabalhar o mundo: os caminhos do novo internacionalismo operário. Rio de Janeiro: Civilização Brasileira, 2005, p.396.
} 
As implicações da nova cultura capitalista sobre o quadro sindical são descritas de forma singular por Giovanni Alves ${ }^{181}$ : "O impacto sobre a subjetividade da força de trabalho é perverso, pois caminha no sentido de suprimir a idealização de classes e as bases subjetivas de uma identificação com um projeto antagônico para além da lógica e dos ideais do capital. O que é perceptível é que um largo espectro do sindicalismo brasileiro abandonou a representação do sindicato como escola da luta de classe (...). O ideal de classe, sob a pressão contingente da defensividade instrumental, transformou-se num ideal corporativo, restrito ao âmbito da empresa, cuja projeção e idealização, no plano da subjetividade de classe, é totalmente capturada pelos ideais do capital."

A reestruturação do sistema produtivo acima narrado traduz-se em modificações na divisão social do trabalho, via transformações estruturais, cujos reflexos verificam-se nos diferentes perfis das posições e segmentos de classe na sociedade ${ }^{182}$. O novo modelo de produção impinge à sociedade a sua marca, levando ao crescimento das formas degradadas de emprego e à expansão da população trabalhadora excedente, de forma a expor a debilidade da classe trabalhadora como um todo. As dimensões sociais, do sistema de produção e do mundo do trabalho, relacionam-se diretamente com a estrutura de classes sociais. Esta estrutura é traduzida em esquemas de direitos formalizados via mecanismo da propriedade dos recursos sociais produzidos e das consequências resultantes sobre a vida das pessoas.

A correlação lógica e sistemática entre sistema produtivo e classes sociais é exemplificada nas palavras de José Alcides Figueiredo Santos ${ }^{183}$ : “A condição de classe afeta os interesses materiais, as experiências de vida e as capacidades para ação coletiva dos indivíduos. O poder causal da posição de classe é exercido ao se condicionar o acesso aos recursos produtivos e ao se moldar as experiências de vida nas esferas do trabalho e do consumo. O que a pessoa tem (ativos produtivos) determina o que ela obtém (bem-estar material) e o que deve fazer para conseguir o que obtém (oportunidades, dilemas e opções). Ao moldarem as experiências no âmbito do trabalho e do consumo e as oportunidades de

\footnotetext{
181 Trabalho e sindicalismo no Brasil dos anos 2000. Dilemas da era liberal. In: Antunes, Ricardo (org). Riqueza e miséria do trabalho no Brasil...Op. Cit., p.469.

182،Tendo em vista o critério teórico de relação das pessoas com o sistema de produção e as marcas que essa relação deixa na estrutura do emprego, as distinções primárias realizadas, em termos de status do emprego, delimitam as categorias de empregador, auto-empregado, empregado, empregado doméstico e trabalhador excluído da produção. (...) A extensão e as implicações das tendências excludentes contemporâneas do papel da força de trabalho no sistema de produção fundamentam a consideração da posição de trabalhador excluído ou excedente." Santos, José Alcides Figueiredo. Uma classificação socioeconômica para o Brasil. Rev. Brasileira de Ciências Sociais. São Paulo, Jun/2005, vol.20, no. 58. Disponível em:
} http://www.scielo.br/scielo.php?script=sci_arttext\&pid=S0102-69092005000200002\&lng=pt\&nrm=iso. Acessado em 04/07/07.

${ }^{183}$ Uma classificação socioeconômica para o Brasil...Op. Cit.p.28. 
vida, esses dois processos primários geram efeitos de segunda ordem (padrões de saúde, atitudes etc.)."

As demandas colocadas pela lógica do capital global sobre a classe trabalhadora são fundamentais, não apenas para entender sua despolitização no interior do sistema produtivo, expressada em parte pelo arrefecimento da ação sindical, mas também para compreender, em certa medida a dificuldade dos mecanismos coletivos de ação social, assunto esse a ser ventilado no item subsequente, sobretudo, no Estado Neoliberal.

Os pilares sobre o qual se assentava o operariado foram ruídos pelo advento do toyotismo que tem por fulcro blindar a relação capital e trabalho pela ausência de questionamento de modo a formatar esse sistema como um conjunto determinado de relações sociais compatíveis com a exploração. Nesse sentido, Ruy Braga ${ }^{184}$ definiu bem a conjuntura: "Trata-se de uma ruptura importante na história das relações de classe. Ela significa que os diques construídos ao longo do tempo pelo movimento operário para se opor à exploração, dotar o grupo de uma consciência de classe e melhor resistir à dominação simbólica cederam amplamente. Resultado: a soberba, a arrogância e as diversas formas de desprezo dos "dominantes", por muito tempo bloqueadas pela existência de uma cultura política operária (institucionalizada), foram liberadas e puderam emergir sem complexos”.

Até aqui se limitou ao aspecto da flexibilização do trabalho no contexto de modificações tecnológicas e reestruturação da organização do trabalho, sendo preciso avançar e abordar um tópico atinente à relação entre financeirização, renda e flexibilização do trabalho ${ }^{185}$. Salama debruçou-se sobre o tema, analisando as economias da America Latina nos anos de 1980 e 1990; mas, essas análises, segundo o autor, são extensíveis e pertinentes, em grande medida, aos países desenvolvidos.

O ponto central do estudo é distinguir a finança entre as modalidades "virtuosa" e "perversa" - criação do capital fictício -, hoje, sem sombra de dúvida, impera a segunda. Quanto às finanças ditas "virtuosas", são imbricadas ao capital produtivo, permitindo o desenvolvimento deste ao financiar os investimentos em uma produção extremamente sofisticada e complexa, permite, também, a proteção do capital produtivo contra riscos advindos de variações cambiais e da taxa de juros, tem até uma veia de fonte de lucro para o capital produtivo.

\footnotetext{
${ }^{184}$ Uma sociologia da condição proletária contemporânea. Tempo Social, São Paulo, v.18, n.1, junho/06. Disponívelem:http://www.scielo.br/scielo.php?script=sci_arttext\&pid=S010320702006000100008\&lng=pt\&nrm =iso. Acessado em 04/07/07.

${ }^{185}$ Salama, Pierre. Pobreza e exploração do trabalho na América Latina. Trad. Emir Sader. São Paulo: Boitempo Editorial, 1999, p. 102/124.
} 
No entanto, a questão ganha novos contornos quando a financeirização é ligada à liberalização dos mercados financeiros, deslocando a mais valia obtida na esfera da produção do investimento produtivo para o mercado especulativo. As nuanças dessa movimentação são melhores analisadas no capítulo III que trabalha em um de seus itens a mundialização da finança, na qual, em apertada síntese, o Estado objetiva financiar seus déficits via emissão de bônus que passam a concorrer com o investimento produtivo e isso só para ficar em um dos ferramentais possíveis da financerização.

O que de fato interessa, nesse momento, é justamente trazer os efeitos do desenvolvimento da financeirização sobre a forma do investimento, o que reverbera sobre a taxa de investimento (setor produtivo que hoje é inferior ao nível dos anos de 1970) e, por conseguinte, sobre o nível de emprego, bem como em sua precarização, cujo resultado final é o incremento da desproporção da elevação da renda do capital quando comparada à do trabalho. Isso porque a financeirização introduz uma pressão adicional sobre o processo de valorização do capital dado que, se tudo o mais continuar constante, o processo produtivo não é mais de per si suficiente para gerar uma taxa de mais valia condizente, de forma que a financeirização, para além da evolução tecnológica, apresenta impactos significativos na flexibilização dos empregos em quaisquer de suas modalidades (seja sobre a extensão da jornada ou sobre a diminuição do tempo de trabalho morto).

Correlacionando o impacto dessa mesma financeirização sob a ótica da análise da atuação dos fundos de pensão e dos fundos mútuos sobre o poder acionário das empresas e suas repercussões na organização do trabalho, Sauviat deixa transparecer, claramente, que se os administradores encontraram meios de contornar a nova realidade, o mesmo não aconteceu com o conjunto da classe trabalhadora.

Os administradores em linha com o imperativo da rentabilidade e de liquidez dos fundos de investimento - novos acionistas das empresas em substituição às tradicionais famílias e que, por isso, passam a reivindicar a primazia de seu interesse em detrimento do da empresa, com base na exigência de um maior retorno sobre suas aplicações - começam a falar a língua da finança "com políticas de crescimento externo capazes de oferecer excedentes financeiros compatíveis com os objetivos expressos pelos mercados e apresentando resultados financeiros igualmente favoráveis e possíveis aos olhos dos analistas financeiros, mesmo ao preço de acrobacias contábeis" ${ }^{186}$.

\footnotetext{
${ }^{186}$ Sauviat, Catherine. Os fundos de pensão e os fundos mútuos: principais atores da finança mundializada e do novo poder acionário. (In) Chesnais François (org.). A finança mundializada. Raízes sociais e políticas,
} 
Isso permitiu não só libertá-los, em parte, do julgo desse novo poder acionário, na medida em que passam a influenciar decisivamente tanto os mercados como aqueles que teriam o dever de controlá-los no interior das empresas (conselho de administração, por exemplo) como ainda ampliaram sua remuneração com base no engenhoso mecanismo de opções de ação (stock-options). Em sentido contrário, situou-se a classe trabalhadora que passou a sofrer os efeitos da maximização do valor acionário, pois "a satisfação das normas de rentabilidade financeira imposta pelos mercados e a mudança induzida na empresa acompanharam a degradação das condições de trabalho dos assalariados e o crescimento das desigualdades de renda. Essa situação se concretizou por uma instabilidade e uma crescente insegurança no emprego, sob a constante ameaça de deslocalização e da subcontratação, e também acarretou forma de controle e de intensificação do trabalho que tiveram como contraponto a precariedade, os baixos salários (exclusão), aumento dos acidentes de trabalho e de doenças profissionais para a grande massa de assalariados. Ao mesmo tempo, esse novo modelo permitiu um importante enriquecimento de uma pequena parcela de assalariados privilegiados, formada de quadros dirigentes ou de alto potencial." 187

\subsubsection{3) Estado Neoliberal}

Antes de falar do Estado neoliberal há de se fazer menção sobre a expressão cunhada de pós-modernidade ${ }^{188}$. Para tanto, Agnes Heller conceitua-a como um viver no presente,

configuração, conseqüências. Trad. Rosa Marques e Paulo Nakatani. São Paulo: Boitempo Editorial, 2005 , p. 124.

${ }^{187}$ Sauviat, Catherine. Os fundos de pensão e os fundos mútuos...Op. Cit., p. 127.

${ }^{188}$ Discorrendo sobre o árduo tema vez que, segundo Eduardo Bittar, não há consenso nem uniformidade quanto à expressão pós-modernidade, o mesmo autor vai tratar de balizá-la como sendo "o estado reflexivo da sociedade ante as suas próprias mazelas, capaz de gerar um revisionismo completo de seu modus actuandi et faciendi, especialmente considerada a condição de superação do modelo moderno de organização da vida e da sociedade. (...) ela é uma condição processante de um amadurecimento social, político, econômico e cultural, que haverá de alargar-se por muitas décadas até a sua consolidação. Ela não encerra a modernidade, pois, em verdade, inaugura sua mescla com os restos da modernidade." Na esteira dessa quadratura, Bittar faz uma incursão no discurso filosófico moderno, com intuito de colher em alguns de seus pensadores preocupações com a nova era que se avizinha (pós-moderna), vindo a situar em Lyotard seu referencial primeiro. Lyotard, segundo Bittar, denuncia a fragilidade do projeto moderno e apõe as reflexões em torno de elementos outros, senão ausentes pelo menos periféricos para a modernidade, de modo que preocupações agora com o fragmentário, o regionalismo e a identidade enquanto elementos de uma nova cultura dissociada do mito moderno do consenso. A partir desse referencial, que foi Lyotard, é possível estabelecer três tendências de pensamento, a seguir delineadas: i) a que rompe radicalmente com a modernidade de onde se elevam Foucault, Derrida e Lacan; ii) a que reafirma a modernidade pelos seus valores iluministas na esteira do pensamento de Habermas; iii) a estratégica que busca a conciliação entre as duas pretéritas. Feitas essas considerações de ordem filosóficas, vê se que Bittar se encontra apto a discorrer sobre o pano de fundo da pós-modernidade a qual traz mudanças histórico-axiológicas decisivas quando se comparadas à modernidade, dentre elas, podem-se fazer referência: a 
estando depois (temporal e espacialmente) no sentido de haver espaços e tempos heterogêneos em contraposição ao projeto Europa de modernidade. ${ }^{189}$

A pós-modernidade tem, segundo a autora ${ }^{190}$, as seguintes características: a) decretação da morte das grandes narrativas (ideia hegeliana do transcendentalismo filosófico e político informado por um narrador onisciente que conta a história, estando em uma posição de superioridade para com ela) situar-se no presente e, ao mesmo tempo, depois dele; b) reciclagem das teorias políticas - pluralismo (várias pequenas narrativas) como instrumento de enfrentamento das generalizações e tendências universalizantes, tendo como extremos: i) negação absoluta do universalismo - renascimento da teoria política de Carl Schmitt e ii) relativização do universalismo - teoria habermasiana do discurso sem dominação formando universalizações relativas posteriores; c) aversão a políticas redentoras - presente como eternidade única e exclusão de qualquer forma de transcendência; d) pós- estruturalismo predomínio do funcional sobre o estrutural que enfraquece os conflitos de classe e que objetiva pelo individualismo pôr um ponto final aos roteiros de classe.

Aqui é perceptível a passagem dos partidos políticos para os movimentos sociais, bem como da racionalidade para a irracionalidade política alimentada pelos interesses egoísticos. Sob o caldo de predomínio do funcionalismo, ${ }^{191}$ Estado é reconceituado, passa ele

alteração da ideologia do desenvolvimento a qualquer custo para o desenvolvimento sustentável e responsável; da razão instrumental para a ética do consenso e da deliberação na seara das decisões corporativas e participativas; do abalo da razão pela crença na perspectiva dos processos de decisão dos problemas sociais e individuais; a substituição da justiça do mercado pela justiça social em matéria de atuação dos atores sociais quando da busca da demonstração do valor pessoal nesse mesmo mercado; na passagem da sociedade industrial para a sociedade de serviços e no ingresso do terceiro setor na antes dicotomia moderna entre Estado e sociedade enquanto demonstração da expansão do poder social nos seus mais diversos níveis. O ambiente antes sumarizado dá o tom do "estado transitivo em que se vive", e autoriza, em seguida, Bittar a avançar para o âmago, ou melhor, para o sentido da pós-modernidade, apondo-a como um período que "tem uma elasticidade heterodoxa, e incomum, capaz de re-criar a partir do velho, e de recuperar a partir do novo. Aliás, um dos traços da pósmodernidade reside exatamente na re-valorização de certas práticas, de certas identidades, de certos modos, de certos valores, de certos dados do passado, que são revisitados, re-valorizados, re-modelados, re-pensados, remaquiados, para servirem como nunca ao presente e ao futuro." Dessa aguda percepção, é plausível extrair o norte da pós-modernidade que, basicamente, é um jogo de incerteza onde passado, presente e futuro se misturam como se fosse à feliz ilustração do expectador no interior de uma sala de espelhos, não se podendo afirmar categoricamente a existência de uma ontologia, uma bandeira ou uma identidade pós-moderna, na medida em que esse estado de coisas avança e colapsa os paradigmas e arquétipos modernos (dentre eles o fordismokeynesianismo). Assiste-se, assim, a troca do padrão - eterno, imutável, absoluto, racional etc... - a metanarrativa da modernidade pelo acaso da pós-modernidade - transitório, relativo, provável etc... - sendo ela "uma vivência sobre os escombros restantes da modernidade em transformação". Bittar, Eduardo Carlos Bianca. O direito na pós-modernidade. Rio de Janeiro: Forense Universitária, 2005, p. 107, 123/125, 139/141, 153, 154, 160, 168, 170 .

${ }^{189}$ Heller, Agnes; Feher, Ferenc. Condição política pós-moderna...Op. Cit., p. 11.

${ }^{190}$ Heller, Agnes; Feher, Ferenc. Ibid, p.12/23.

191 Essa concepção deita-se na incerteza, fruto do incremento da complexidade, da indeterminação e da contingência da sociedade atual, na qual a racionalidade iluminista não consegue mais dar conta. Essa nova realidade impinge uma releitura da sociedade nas quais as categorias de sujeito, objeto e de relação de causalidade dão lugar a uma "racionalidade sistêmica", cujos parâmetros remontam a: i) não aceitação de valores enquanto verdades absolutas, ii) justificação auto-referencial dos sistemas, iii) legitimação pelo procedimento, 
de agora em diante a ser tratado como "uma máquina enxuta, mas funcional, desprovida de qualquer conteúdo material, e, portanto, ulteriormente capaz de estabelecer simulacros de equilíbrio e ordem. Assim, reduz-se o problema do poder do Estado liberal à instrumentalização puramente mecânica, necessária para se governar um conjunto de forças abstratas. No sistema, no mecanismo de equilíbrio, a figura do Estado como agente social desaparece. O Estado é, em última análise, um sujeito fraco e um guardião neutro da ordem." 192

$\mathrm{Na}$ esteira destas observações, cabe aqui desenvolver outro aspecto do processo de globalização, para além da alteração das relações de produção acima tratadas, qual seja: a redução do espaço político pelo econômico, com o apogeu da técnica, cujo mote é blindar as decisões econômicas do debate político vez que os liberais advogam a tese da incompatibilidade entre excesso de democracia e governabilidade. ${ }^{193}$

A concepção liberal deita-se na lógica da subsunção real do trabalho ao "capital autômato" em virtude do deslocamento da esfera da produção para a da circulação, como momento fundamental para a reprodução do sistema informado por inovações tecnológicas. A subsunção do formal no real tem como consequências: i) autorizar ao capital a dissimular o papel do trabalho; ii) permitir a mudança do padrão social - de disciplinar para de controle; iii) expandir a lógica capitalista para todas as formas de produção social e, em especial, no campo dos direitos sociais, haja vista a negação da sociedade civil pela negação da atividade da força de trabalho como fonte de riqueza social. ${ }^{194}$

Para ilustrar uma parte dos dizeres acima, basta ver o trabalho de Wacquant ${ }^{195}$, que em larga medida opõe-se ao funcionalismo, sobre a gestão da miséria nos Estados Unidos no final do século XX. Este trabalho, desenvolvido a partir das peculiaridades desse Estado centralidade da ideia do individualismo mais a divisão estanque do Estado entre de um lado o "social insurance" atrelado ao trabalho e de outro, o "welfare" voltado ao tratamento da miséria -, discorre sobre a passagem do Estado caritativo para o Estado penal. O mecanismo, para além da simplista política de encarceramento, vale-se da assistência social que passa a ter

iv) centralidade de critérios empírico-faticos de legitimidade a fim de capacitar os sistemas sociais a lidarem com níveis atuais de incerteza e complexidade. A título de exemplo, tome o direito onde sua validade não tem qualquer relação com critério exterior (seja ele de valores - jusnaturalistas ou de vontade - positivista), mas única e exclusivamente na sua "lógica de reprodução circular". Diniz, Antonio Carlos de Almeida. Teoria da legitimidade do direito...Op. Cit., p. 220/224 e 229.

${ }_{192}$ Negri, Antonio; Hardt, Michael. O trabalho de Dioniso...Op.Cit., p.81.

${ }^{193}$ Bercovici, Gilberto. Soberania e Constituição...Op.Cit.,p.334.

${ }^{194}$ Negri, Antonio; Hardt, Michael. O trabalho de Dioniso...Op. Cit., p.55/59 e 180/181.

195 Wacquant, Loïc. Punir os pobres. A nova gestão da miséria nos Estados Unidos. Rio de Janeiro: Instituto Carioca de Criminologia. F. Bastos, 2001, p. 21/23, 27/28. 
um papel relevante no campo da vigilância e do controle das "classes desfavorecidas", tanto na base do "workfare" (obrigatoriedade do beneficiário aceitar qualquer emprego sob pena de vir a ser excluído do programa assistencial) como no do "learnfare" (atrelar o benefício à assiduidade escolar do filho). Essa movimentação vem em linha com os preceitos da nova ordem econômica que prima pela responsabilidade pessoal/individual, pelo fracasso e, por conseguinte, pela pobreza, outorgando à miséria um novo tratamento, agora não mais na base do arrefecimento de suas consequências, mas sim na "guerra contra os pobres". No fundo, o primado do Estado policialesco no âmbito da legislação social, na qual o simples fato de alguém ser possuidor de um emprego lhe outorga um privilégio que, em última analise, na seara social, abranda as disposições do trabalho em face do capital.

Em síntese, essa nova concepção de Estado ${ }^{196}$ objetiva marcar o fim da dialética entre capital e trabalho na constituição do Estado, seja pela autonomia da produção social ou da centralização do momento da circulação em detrimento do instante da produção. Instância essa que informou os modelos de Estado - moderno e keynesiano; o primeiro, na singela relação entre capital e trabalho; o segundo, nessa mesma relação, só que mediada pelo Estado, via planificação e regulação econômica, e agora sai de cena na medida que a clássica fórmula (D-M-D) transforma-se em (D-D).

Estas alterações advindas da nova ordem internacional reverberam, segundo Losurdo $^{197}$, em uma tendência de redução do próprio conceito de democracia vez que ela "não consegue realizar suas promessas nem quanto aos direitos materiais nem quanto à participação dos cidadãos nas escolhas políticas" e estabelecem a marca da sociedade hodierna, qual seja: abismo entre as democracias política e social, o que permite trazer à baila o assunto da abertura dos serviços públicos à lógica do mercado, bem como do desmantelamento do Estado social, pela via das reformas constitucionais, cuja significação deita-se, em última instância, na lógica da privatização do público.

A passagem da supremacia do político (poder legislativo e partidos políticos) para o executivo (gestão administrativa da sociedade) carreia consigo a produção legislativa, saindo da esfera do social - capital e trabalho - dentro da lógica da soberania popular para a esfera administrativa, que se baliza constantemente das decisões de mercado, e de normas técnicas. ${ }^{198}$

\footnotetext{
${ }^{196}$ Negri, Antonio; Hardt, Michael. O trabalho de Dioniso...Op. Cit., p.173/175.

${ }^{197}$ Losurdo, Domenico. Democracia ou Bonapartismo...Op. Cit., p. 279.

${ }^{198}$ Negri, Antonio; Hardt, Michael. O trabalho de Dioniso...Op. Cit., p. 178/180.
} 
Aqui é relevante fazer um parênteses e relembrar o escopo precípuo do Estado de direito, qual seja: o controle da burocracia estatal na medida que opõe ao Estado às liberdades individuais consubstanciadas nos direitos civis e políticos, sendo este o pano de fundo de toda a teoria política clássica. Weber mostrou o quão importante é a burocracia para o funcionamento e organização do Estado burguês, assinalando a derrocada da razão iluminista - "racionalidade substancial" ínsita ao parlamento pela "racionalidade instrumental" da administração. Isso porque o Estado capitalista não deita sua legitimidade no ato de fundação, mas sim na sua atuação perpetrada por um corpo de intelectuais orgânicos, senhor de um saber científico angariado pelo Estado e distinto das classes dominantes.

Esta associação entre ciência e poder é essencial para a mudança da ideologia reinante - da jurídica-politica para a tecnocrática ${ }^{199}$. Acrescente-se, ainda, que ao longo do século XX, pelos motivos declinados, o Estado foi convocado a participar mais acentuadamente na vida econômica da sociedade, redundando no fortalecimento do executivo e na mutação do marco legal, pois as "leis não se inscrevem mais na lógica formal do sistema jurídico, fundamentada na universalidade da norma e na racionalidade da vontade geral representada por seu editor, mas num registro diferente, o da política econômica concreta $e$ rotineira, encarnada pelo aparelho administrativo. "200

O deslocamento do centro decisório do parlamento para o executivo torna, imediatamente, a administração "o elo central da elaboração do instável equilíbrio de compromissos no seio do bloco do poder, entre este e as massas populares" mediatamente, rompe com a falácia da separação de poderes e provoca uma redução das liberdades políticas. Redução essa que deságua em um Estado de exceção, no qual se cancela a própria república democrática burguesa, ensejando um "estatismo totalitário", enquanto mecanismo de reação à crise produzida pelo Estado-providência, mais especificamente, pelo esgotamento desse modelo, na medida que "as contra-tendências para a baixa tendêncial da

\footnotetext{
${ }^{199}$ Essa separação entre trabalho manual e trabalho intelectual é decisiva no caso do Estado. "E é no Estado capitalista que a relação orgânica entre trabalho intelectual e dominação política, entre saber e poder, se efetua de maneira mais acabada. Esse Estado, afastado das relações de produção, situa-se precisamente ao lado do trabalho intelectual ele mesmo separado do trabalho manual: ele é o corolário e o produto desta divisão ao deter um papel próprio em sua constituição e sua reprodução. (...) É principalmente por uma cristalização do trabalho intelectual que esses aparelhos, em sua forma capitalista (exército, justiça, administração, policia, etc.), para não citar os aparelhos ideológicos, implicam exatamente a efetivação e o domínio de um saber e de um discurso (...) em que as massas populares estão excluídas. (...) É a monopolização permanente do saber por parte do Estado-sábio-interlocutor, por parte de seus aparelhos e de seus agentes, que determina igualmente as funções de organização e de direção do Estado, funções centralizadas em sua separação especifica das massas (...) É igualmente evidente que uma série de instituições da democracia representativa, dita indireta(partidos políticos, parlamento, etc.) dependem do mesmo mecanismo". Poulantzas, Nicos. O Estado, o poder e o socialismo...Op. Cit., p.62/65 e 69.

${ }^{200}$ Poulantzas, Nicos. Ibid, p.253.

${ }^{201}$ Poulantzas, Nicos. Ibid, p.256.
} 
taxa de lucro, colocadas em ação pelo Estado para evitar as crises, tornam-se fatores de uma crise que, mediante isso, ultrapassa a simples crise econômica", 202

O tema do esgotamento do padrão fordista e do seu consectário Estado providência, nos idos dos anos de 1970, será detalhado no capítulo III deste trabalho. O que interessa, nesse instante, é a repercussão de toda essa movimentação oriunda da globalização que impingiu não só um "novo conceito" de Estado com reflexos ao "conceito de democracia", esta última objeto extensa análise por parte dos teóricos liberais, o que finda por ecoar na legislação estatal como um todo, seja a constitucional e, sobretudo, a social de modo que " $d o$ ponto de vista jurídico, a lei capitalista tornou-se natural, mesmo nos seus aspectos mais abstratos. O dinheiro substituiu a norma jurídica. A sociedade civil foi reduzida a um mecanismo administrativo, a um sistema de mecanismos de compensação de uma cooperação que é pura e exclusiva técnica, dedicada à reprodução das atuais relações sociais. A lei, mais especificadamente, é representada de duas maneiras: como uma série de normas processuais que regulam a normalidade dos processos de reprodução ou como uma série de regras excecionais que restabelecem a normalidade do processo de produção. Entre automatismo processual e estado de exceção, a existência da própria sociedade civil e a sua participação nos mecanismos jurídicos como meio de formação de uma autoridade legitima são negadas. No Estado pós- moderno, a separação dos termos constitutivos da sociedade entre quem obedece e quem comanda se torna total, como prescreviam as definições antigas $e$ tradicionais da autoridade (e, sob esse aspecto, o pós-moderno parece surpreendentemente pré-moderno)." 203

Os dizeres de Negri e Hardt acima reproduzidos são uma mostra do "esvaziamento da legalidade" 204 sob a qual o capitalismo industrial outrora se arquitetou (universalidade formal), aprofundando, assim, seu arquétipo (da "ordem" para a “impossibilidade"), na medida que o capital financeiro logrou a máxima autonomia e dominação diante do social.

Nesse sentido, sua autorreprodução pode prescindir do regramento jurídico local, pois, imediatamente, identifica-o à esfera do contrato e da propriedade e, mediatamente, o capital se escorra na ausência de alternativas possíveis, em virtude da "impossibilidade econômica em sentido contrário". O capital financeiro, no entanto, não pode abdicar de um ferramental como é o Estado, pois, em última instância, é ele quem mantém a ordem social e garante um ambiente propício à acumulação. Basicamente, o que se performou pela

\footnotetext{
202 Poulantzas, Nicos. O Estado, o poder, o socialismo...Op. Cit., p.245.

${ }^{203}$ Negri, Antonio; Hardt, Michael. O trabalho de Dioniso...Op. Cit., p.181/182.

${ }^{204}$ Mascaro, Alysson Leandro. Para uma crítica da legalidade no Brasil contemporâneo...Op. Cit., p.123/132.
} 
globalização foi a homogeneização do mundo pelo modelo único de economia (de escala e de utilidade individual), a qual simboliza não apenas o paradigma de progresso, como também a realização do projeto de modernidade. ${ }^{205}$ Eis aí, na verdade, a força e a fraqueza do Estado, pois a construção de um "Estado fraco" necessariamente passa por decisões oriundas de um "Estado forte".

Indo em direção ao fim do tópico, falta falar do judiciário que não sai incólume da passagem do Estado legislativo para o Estado burocrático. Sem trabalhar na linha do tradicional "ativismo judiciário" ou da "jurisdicialização da política" sob o fundamento do judiciário ser o garante dos direitos e liberdades fundamentais, bem como do controle da atividade do executivo ou, ainda, do poder do capital, via demandas de massa.

Bercovici $^{206}$ apresenta uma leitura bem peculiar e deveras interessante na medida que associa a crise do Welfare à crise da política e, em particular, do legislativo e dos partidos políticos em que saem da cena constitucional, deixando campo livre para a emergência dos tribunais em uma das duas vias, a saber: i) a da "constituição dirigente" - onde predomina a ideia de futuro em razão do aspecto diretivo que, no fundo, distancia-se dos objetivos pela sua não realização; ii) a da mitigação do "conteúdo político da constituição", erigindo-a a "norma suprema", tal como fora teorizado pelas teorias normativas do direito. Esse ambiente é propulsor da substituição da política democrática pela interpretação constitucional dos tribunais que se legitima na esteira da descrença da democracia representativa e irá extrapolar suas funções - de guardião do poder constituinte a poder constituinte propriamente dito. E isso em um breve espaço de dois séculos o que perverte toda a lógica da democracia, com a inversão dos problemas, pois se, no século XIX, a questão remonta ao tratamento do "o princípio majoritário"; hoje, ela ganha contornos de "o princípio contra-majoritário".

Por trás do enfraquecimento do político, seja pela via do executivo ou do judiciário, reside o real interesse das classes dominantes, qual seja: realizar a idéia do contratualismo moderno quanto à separação Estado e sociedade e, assim, "isolar, por exemplo, as instituições econômicas da política democrática, ou em garantir determinada concepção políticoideológica apesar das maiorias democráticas, preservando-se interesses hegemônicos que podem não ter mais sustentação popular.” E a emergência dos tribunais, na realidade, é um sintoma do fato de que a constituição e a política apartaram-se, e a constituição hoje é um "mero limite formal à ação dos atores políticos".

\footnotetext{
${ }^{205}$ Muzio, Gabriele. A globalização como estágio de perfeição do paradigma moderno: uma estratégia possível para sobreviver à coerência do processo. In: Oliveira, Francisco de; Paoli, Maria Célia (org). Os sentidos da democracia. Políticas do dissenso e hegemonia global. 2a ed. Petrópolis: Vozes, 2000, p. 138/139.

${ }^{206}$ Bercovici, Gilberto. Soberania e Constituição...Op.Cit., p.321/326 e 335.
} 
O mecanismo de neutralização da política seguido da blindagem do econômico tem no Brasil, em especial, um fenômeno batizado de "constituição dirigente invertida", expressão da superioridade da "constituição financeira" sobre a "constituição econômica", espaço no qual o ativismo judicial prospera muito mais em prol da " ordem de mercado e limitar o poder de atuação do Estado do que para garantir ou ampliar direitos fundamentais". E mais, esse contexto de deslegitimação da constituição ${ }^{207}$ pode ser mensurado pela adoção, basicamente, de dois mecanismos: i) tecnicização dos direitos, a fim de descolá-los do político e, por conseguinte, das contradições sociais; tecnicização essa desenvolvida pelas reformas infraconstitucionais, em especial, da legislação processual e pelo "novo pathos" assumido pelo judiciário - operador do direito - informado pela ótica de Capelletti ${ }^{208}$ que remonta à questão do acesso à justiça pelo econômico e não pelo social e, desta forma, inverte a relação de causa e efeito; ii) emendas constitucionais que, na prática, foram mecanismos de "naturalização da ilegalidade" por reiterados golpes de estado institucionalizados, pois o "direito, antes a máscara universal a beneficio do capitalismo, agora é a afirmação arrogante do velho direito do mais forte, que é a negação de qualquer noção moderna de direito, mas esta arrogância é, na verdade, a face explicita de uma nova lógica políticoeconômica imperial do próprio capitalismo, e não apenas de sua política, ${ }^{209}$.

\footnotetext{
${ }^{207}$ Mascaro, Alysson Leandro. Para uma crítica da legalidade no Brasil contemporâneo...Op. Cit., p.178, 215, $226 / 235$

${ }^{208}$ Em dois trabalhos, Cappelletti é enfático na questão da acessibilidade ao sistema judiciário. Num, ele trata da questão do acesso dentro da moderna processualística, porquanto a questão da justiça social passa, necessariamente, pela questão do acesso enquanto direito fundamental dentro da lógica da passagem do Estado liberal para o social. O exame das barreiras ao acesso é feito, no mais das vezes, em torno da questão financeira, seja das custas processuais, dos juizados de pequenas causas, da análise da capacidade financeira das partes, etc. No outro, o autor defende a premência do acesso conjugando as teses de Martin Shapiro (o qual vê no acesso ao judiciário uma forma de grupos alijados do processo político fazem valer seus direitos) e de Shirley Hufstedler (a qual assevera que as portas dos tribunais são as mais democráticas, cujo ingresso se dá pela via da petição/ação e cujo procedimento por ser público é democrático diferentemente das decisões do legislativo e do executivo. Cappelletti, Mauro; Garth, Bryant. Acesso à justiça. Trad. Ellen Gracie Northfleet. Porto Alegre: Sergio Antonio Fabris Editor, 2002, p.7/13 e 28/29.

Cappelletti, Mauro. Juízes legisladores? Trad. Carlos Alberto A. de Oliveira. Porto Alegre: Sergio Antonio Fabris Editor, 1993, p.99/100 e 105/106.

${ }^{209}$ Mascaro, Alysson Leandro. Para uma crítica da legalidade no Brasil contemporâneo...Op. Cit., p.178.
} 


\section{Capítulo II) A indissociabilidade entre capitalismo e direito}

Para os objetivos do capítulo ora proposto há de se ter como horizonte a feliz constatação de Alain Touraine ${ }^{210}$ quanto à singularidade e à contemporaneidade do pensamento de Marx, na medida que ele "é moderno no mais alto grau, porque ele definiu a sociedade como um produto histórico da atividade humana, e não como um sistema organizado ao redor de valores culturais ou mesmo de hierarquia social. Mas ele não identifica a visão modernista com o individualismo; ao contrário, o homem do qual ele fala é em primeiro lugar o homem social, definido por seu lugar no mundo da produção em um universo técnico e em relações de propriedade, um homem definido mais por relações sociais do que pela busca racional do interesse".

Este pensamento espraia-se para o direito por meio do ensaio produzido por Pasukanis - Teoria Geral do Direito e Marxismo - que, de pronto, expõe as insuficiências da Teoria Geral do Direito ao se deparar com a realidade objetiva, pois esta para ser compreendida, em sua totalidade, deve-se valer da sociologia, em virtude da dissonância entre a verdade jurídica e a verdade sociológica; a primeira regida pelo princípio da validade, a segunda, pelo princípio da eficácia.

Corrobora com a incapacidade primeira do direito a sua precária teorização, na medida que a dogmática jurídica procura assentar as ambigüidades sociais no racionalismo universal e abstrato das relações humanas, esquecendo-se, por completo, de que a sociedade funda-se, em última instância, na desigualdade e na divisão social em classes. O corte metodológico produzido pela Teoria Geral do Direito lhe autoriza a ficar restrita aos limites das definições formais, cujo preço a ser pago é auferido, imediatamente, pela vedação de todo e qualquer potencial crítico presente, de início, nas ciências de modo geral e, mediatamente, na redução do direito à técnica, equalização essa de importância ímpar para a reprodução do sistema capitalista.

Em um primeiro instante, tal redução remonta à cisão promovida por Kant entre direito e política, seguida pelo avanço da legalidade que culminou na "plena impessoalidade da técnica jurídica contemporânea" que não só consolida as categorias elementares do direito na neutralidade de cunho formal e universal, mas que também "opera nos limites da institucionalização legalista” de modo a promover a legitimação do capital. ${ }^{211}$

\footnotetext{
${ }^{210}$ Crítica da modernidade...Op. Cit.,p.89/90.

${ }^{211}$ Mascaro, Alysson Leandro. Para uma crítica da legalidade no Brasil contemporâneo...Op. Cit., p.45, 47, 49, 54.
} 
O tema da técnica jurídica ${ }^{212}$ é tão relevante que ela não apenas embasa a ideologia jurídica, podendo-se, assim, qualificar como sua função secundária, mas também, e sobretudo, instrumentaliza a atividade capitalista em sua integralidade seja ela em seus momentos estático ou dinâmico. É ela quem chancela a todos, como sujeito de direito, quem os trata como livres - capazes de manifestar vontade - quem possibilita a celebração de todo e qualquer tipo de contrato, quem se faz presente quando do inadimplemento, quem respalda a propriedade privada. Em resumo, é ela quem garante a exploração do trabalho pelo capital, na medida que considera todos - empregador e empregado - como iguais perante a lei, tornandose o baluarte para a desigualdade real.

Outro ponto de relevo, refere-se à singularidade da abordagem de Pasukanis, destoando das análises marxistas tradicionais que veem a ideologia como traço distintivo do direito. $\mathrm{O}$ autor coloca a questão do direito em outro patamar, qual seja: apreensão do direito como "categoria histórica de um regime social", traçando sua démarche à semelhança de Marx nos estudo de economia política, cujo método ${ }^{213}$ vai do "abstrato ao concreto" e do "simples ao complexo", a fim de apreender o objeto, qual seja: as relações de economia mercantil, em franca oposição aos clássicos Smith e Ricardo que se debruçaram sobre a economia de "forma geral". Deste modo, Pasukanis propugna pelo estudo do direito de maneira que "as abstrações jurídicas fundamentais que engendram a evolução do pensamento jurídico, as quais representam as definições mais próximas da forma jurídica como tal, refletem relações sociais bastante precisas e complexas. "214

Silvio Luiz de Almeida ${ }^{215}$ bem estabelece esse contraponto no âmbito do marxismo ao comparar as concepções de Lucáks, extensíveis a Reisner e de Pasukanis que outorgam dimensões e resultados distintos ao direito. Para Lucáks, o determinante está nas forças de

\footnotetext{
${ }^{212}$ Mascaro, Alysson Leandro. Introdução ao estudo do direito. São Paulo: Quartier Latin, 2007, p. 43/45.

${ }^{213}$ Resultado do acerto de contas com a Economia Política, cujo método (analítico) parte do todo/concreto ao simples/abstrato, que, no limite, depara-se com a volatilização daquele neste. Marx produz uma dupla inversão no método da economia política. Primeiro, ao valer-se de Hegel, que vê o concreto como o resultado e não o ponto de partida do pensamento, pois o concreto é "a síntese de muitas determinações - unidade do diverso". Assim, deve-se proceder do abstrato ao concreto, a fim de reproduzir a realidade pela consciência. Todavia, apresenta um diferencial para com Hegel, porquanto este identificava o pensar como "processo de gênese do próprio concreto" e em Marx, o pensar é a "representação em conceitos do concreto". Depois, a fim de não se desfazer do processo histórico, Marx vale-se das "leis do pensamento abstrato que vai do simples ao complexo" de modo que apreender a economia burguesa enquanto organização social "mais desenvolvida e mais diferenciada" carreando consigo todas as formas anteriores de sociedade. Marx, Karl. Contribuição a crítica da economia política. $2^{\mathrm{a}}$ ed. Trad. Florestan Fernandes. São Paulo: Expressão Popular, 2007, p. 255/266.

${ }^{214}$ Pasukanis, E.B. Teoria geral do direito e o marxismo...Op. Cit., p.22.

${ }^{215}$ O direito no jovem Lukács: a filosofia do direito em História e Consciência de Classe. São Paulo: AlfaOmega, 2006, p. 116/122.
} 
produção, na ideologia e na dialética do tipo hegeliana ${ }^{216}$, cujo desenvolvimento dá-se pela "teoria da constituição do poder, teoria dos modos de dominação inerentes ao Estado" - que, no limite, deságua na discussão trazida no capítulo pretérito, quando dos desdobramentos da obra Crítica da Filosofia do Direito de Hegel. Dissentindo está Pasukanis, para quem o determinante encontra-se nas relações de produção e no fetichismo, cuja derivação escora-se na "teoria da sujeição" - que conduz à crítica da economia política no tocante à correlação entre produção e circulação propiciada pela equivalência, a fim de desenvolver "o mundo econômico-jurídico expresso no valor das mercadorias e na igualdade dos sujeitos de direito".

O terceiro ponto significativo do título Teoria Geral do Direito e o Marxismo está no estudo das dicotomias centrais da TGD (direito objetivo e subjetivo; direito público e privado), dualidade esta que é fruto da separação entre Estado e Sociedade Civil, viés decisivo para o desenrolar do ensaio aqui proposto. Para Pasukanis, essas dicotomias não são simples artificialidades produto das idéias dos teóricos do direito; elas, na verdade, refletem a relações sociais que radicam na realidade das relações de produção e de troca ínsitas ao sistema capitalista.

Saliente-se que, de forma alguma, o autor desdenha as dicotomias apresentadas, pelo contrário, ele as tem como ponto de partida, fazendo da dualidade - subjetivo (jus agendi) e objetivo (norma agendi) - o imperativo lógico a sua própria teorização, tal como Marx fizera com a economia política, no tocante à divisão da mercadoria em valor - de troca e de uso. ${ }^{217}$ Esta abordagem permite-lhe uma visão singular do direito, pois a par de suas determinações gerais, "ele tem uma história real paralela, que se desenvolve não como um sistema de idéias, mas como um sistema específico de relações no qual os homens entram em conseqüência não de uma escolha consciente, mas porque a isso lhes obrigam as condições de produção. (...). Assim, a relação jurídica pode ser entendida como uma relação abstrata unilateral, mas cujo

\footnotetext{
216 No prefácio de 1967, Lukács deu seu testemunho quanto a sua ligação de sua obra com a herança hegeliana e com o desvio do marxismo ortodoxo. Quanto a este, Lukács tomou a ideologia pela economia e não pela categoria trabalho, isso lhe traz um custo que é a perda da "objetividade revolucionária" deslocando-se para um "subjetivismo dominante", na medida em que não logra atingir a "relação entre teoria e prática ou sujeito e objeto". Depois, ele afirmou haver um segundo problema que é o enfrentamento com o método hegeliano e, mais especificamente, quanto à categoria alienação. Aqui, Lukács afirma que a obra padece de um "hegelianismo exacerbado", porquanto o seu trabalho dá a impressão de que "Hegel estava caminhando com as próprias pernas" ao trocar o tratamento do sujeito/objeto lógico-filosófico pelo sujeito/objeto histórico-social que redundaria na consciência de classe enquanto justificativa filosófica à revolução, mas que, na verdade, subliminarmente, voltou-se ao idealismo, em prejuízo do materialismo. Lukács, Georg. História e Consciência de Classe. Estudos sobre a dialética marxista. Trad. Rodnei Nascimento. São Paulo: Martins Fontes, 2003, p.15/27.

${ }^{217}$ Pasukanis, E.B. Teoria geral do direito e o marxismo...Op. Cit., p. 22.
} 
caráter unilateral não é o produto de uma elaboração conceitual, mas sim o resultado do desenvolvimento social. ",18

Logo, o âmago para a compreensão da evolução histórica da sociedade burguesa, bem como de seus limites está na "dialeticidade dos conceitos jurídicos" sistematizados pela TGD. Esta linha autoriza Pasukanis a valer-se da universalidade das categorias jurídicas que exprimem, simultaneamente, "as condicionantes de um sujeito histórico determinado" e os estágios antecedentes da própria sociedade, uma vez que a evolução histórica tem a virtude de desnudar as vicissitudes do passado. ${ }^{219}$

Pasukanis elabora o eixo de sua teoria jurídica em torno da forma jurídica que o conduz do abstrato à concretização histórica, pois "a evolução histórica acarreta não apenas uma modificação no conteúdo das normas jurídicas e uma modificação das instituições jurídicas, mas também o desenvolvimento da forma jurídica como tal (...). Esta última surge em determinada etapa da civilização e permanece por muito tempo em estado embrionário, (...). Desenvolvendo-se gradualmente, ela alcança depois o seu máximo florescimento e sua máxima diferenciação e determinação". 220

Somente o último estágio de evolução social logra edificar um sistema de conceitos gerais acerca do sistema jurídico como totalidade de maneira que as "categorias jurídicas burguesas" são construções conscientes, posteriores e necessárias às práticas do sistema capitalista a fim de subjugar suas dificuldades inerentes, devendo elas ser tomadas com o intuito de descobrir o verdadeiro significado, qual seja: expor "os condicionamentos históricos da forma jurídica" 221.

Depreende-se daí que a forma jurídica ${ }^{222}$ é o elemento nuclear para a compreensão das relações sociais capitalistas, pois fornece a linha histórica evolutiva do direito, a especificidade em uma determinada forma de sociedade, bem como põe às claras o modo pelo qual ela realiza a equiparação entre "legalidade e capitalismo" 223 para além da perspectiva da associação capitalismo/legalidade que surge na circulação e consolida-se na produção capitalista.

Feitas as considerações preliminares, o trabalho dirige-se, agora, à aproximação entre direito e economia política que, no limite, conduz à indissociação entre as formas

\footnotetext{
${ }^{218}$ Naves, Márcio Bilharinho. Marxismo e direito. Um estudo sobre Pachukanis. São Paulo: Boitempo, 2008, p.42.

${ }_{219}$ Pasukanis, E.B. Teoria geral do direito e o marxismo...Op. Cit., p.38.

${ }^{220}$ Naves, Márcio Bilharinho. Marxismo e direito...Op.Cit., p.47.

${ }^{221}$ Pasukanis, E.B. Teoria geral do direito e o marxismo...Op. Cit., p.29.

${ }^{222}$ Naves, Márcio Bilharinho. Marxismo e direito...Op.Cit., p.47/48.

${ }^{223}$ Mascaro, Alysson Leandro. Para uma crítica da legalidade no Brasil contemporâneo...Op. Cit., p.73.
} 
jurídica e mercantil, informadas pelo princípio da troca de equivalentes, seja no momento da produção (trabalho e remuneração) ou no momento da circulação (troca de valores/mercadorias). Este duplo instante além de elementar autoriza a compreensão das outras relações sociais, todas elas jurídicas, pois "somente a sociedade burguesa capitalista cria todas as condições necessárias para que o momento jurídico alcance a sua plena determinação nas relações sociais". ${ }^{224}$ Assim, passando em revista por Pasukanis somado com a contribuição de Edelman, pode-se o expor o núcleo estrutural do direito e, por conseguinte, dos direitos sociais ${ }^{225}$ com vistas a municiar o capítulo subsequente desta dissertação.

\section{1) O direito privado em sua essência}

\section{1) Momento produção $-1^{a}$ troca}

A Economia Política pauta-se pelo primado do processo social na circulação informada pela liberdade e igualdade jurídicas, estendendo essa estrutura para o conjunto da sociedade que passa a ser concebido, como "verdadeiro paraíso dos direitos do homem", onde reina o contrato celebrado entre "trocadores de mercadorias" que se movem, conforme seus interesses pessoais, cujo somatório resulta no interesse social. Esta perspectiva permite não só desviar o foco do cerne do capitalismo - processo produtivo - apagando a contradição inicial e elementar da sociedade, como também aceita que ela se organize sobre si mesma, de forma natural e a-social, traduzindo a linearidade da passagem da sociedade pré-capitalista para a capitalista $^{226}$.

Marx opõe-se a essa visão pelo materialismo, pautado no binômio - historicidade e especificidade, cuja origem remonta as lutas e contradições das relações sociais; refutando, desta maneira, os pressupostos da economia política, bem como suas ideias de progresso

\footnotetext{
${ }^{224}$ Naves, Márcio Bilharinho. Marxismo e direito...Op.Cit., p. 50/51.

${ }^{225}$ O termo - direitos sociais -, nesse capítulo, será, basicamente, tratado em seu sentido estrito: direito do trabalho, justamente para marcar a diferença entre os momentos produção e circulação. Quando houver necessidade de se mencionar o termo - direitos sociais em sentido amplo -, ele o será feito expressamente. Todavia, para que fique desde já balizado, o conceito de direitos sociais utilizado por esta dissertação é do capitulo seguinte, mais abrangente envolvendo outros direitos. Correlação semelhante pode ser verificada na topografia do texto Constitucional que arrola no Titulo II - Dos Direitos e Garantias Fundamentais - e no Capitulo II - Dos Direitos Sociais - versando basicamente sobre o direito do trabalho nos art. 7 a 11; tratando os demais direitos sociais, arrolados no art. 6, no Titulo VIII referente à Ordem Social.

${ }^{226}$ Sader, Emir. Estado e política em Marx: para uma critica da filosofia política. São Paulo: Cortez, 1993, p. $35 / 38$.
} 
linear advindo das leis da história universal ou da natureza humana ${ }^{227}$. Esta abordagem lhe autoriza a investigar a "relação existente entre produção e história", pela especificidade do capitalismo e do direito que aí emana, possibilitando apreender a economia, como uma unidade, um todo orgânico informado, simultaneamente, por todos os seus momentos (produção, distribuição, troca e consumo), com a centralidade na esfera da produção, que determina, em último grau, as demais instâncias.

Se os economistas definem o Capital "como meio de produção, como trabalho acumulado que se presta a uma nova produção", 228 Marx vai dissentir desse conceito ao afirmar que tal equiparação não é correta, uma vez que "os meios de produção existem em todas as sociedades, mas nem por isso elas conhecem o capital. O que é um escravo negro? Um homem da raça negra. Tanto faz uma resposta como a outra. Um negro é um negro. Em determinadas circunstancias, se converte em escravo. Uma máquina de fiar algodão é uma máquina de fiar algodão. Só em determinadas circunstâncias se converte em capital. Separado do contexto, não é capital, tal como o ouro não é de per si dinheiro, nem açúcar é o preço do açúcar. Nessa passagem, Marx mostra claramente que os meios de produção não são capital por sua natureza, que é necessário que determinadas condições ocorram para que os meios de produção tornem-se capital" ${ }^{\text {229 }}$.

Caso assim não o fosse, haveria de se concluir que o capital teria uma natureza eterna, presente invariavelmente em toda a história da humanidade, ou seja, isso seria o mesmo que afirmar que o capitalismo existiu desde sempre e existirá para todo o sempre, deixando de lado sua especificidade e historicidade. Esta divergência de Marx com os autores da Economia Política transmuta a noção de capital ${ }^{230}$ como coisa (de soma em dinheiro, de riqueza acumulada) e apõe-lhe a noção de relação social (relação de produção da sociedade burguesa) entre duas classes, a burguesia e o operariado, cuja compleição decorre da junção das "condições materiais de produção" de uma com a "força de trabalho" de outra, com a singularidade de que esta última se esvai no processo de produção, tendo em vista a realização da passagem do consumo feudal à circulação capitalista.

Extrai-se daí, o momento nuclear dado pelo encontro entre as duas classes sociais na esfera da circulação, pois o surgimento histórico do capitalismo é indissociável da forma trabalho assalariado - momento em que a força de trabalho assume a forma de mercadoria

\footnotetext{
${ }^{227}$ Wood, Ellen Meiksins. Democracia contra capitalismo. A renovação do materialismo histórico. Trad. Paulo Cezar Castanheira. São Paulo: Boitempo, 2003, p. 16/17.

${ }^{228}$ Naves, Márcio Bilharinho. Marx. Ciência e revolução. São Paulo: Moderna; Campinas: Editora da Unicamp, 2000, p. 60.

${ }^{229}$ Naves, Márcio Bilharinho. Marx. Ciência e revolução...Op. Cit., p. 60/61.

${ }^{230}$ Naves, Márcio Bilharinho. Marx. Ibid, p.61/64.
} 
("trabalho vivo indiferenciado"), permitindo, assim, a realização da teoria do valor. Vê-se, portanto, que o fundamental reside na determinação formal, pois além de corporificar o modo de produção capitalista como "uma etapa histórica da produção humana", a forma (mercadoria) autoriza: i) a produção para a circulação; ii) a aquisição de valor pela própria coisa, independente de sua origem que, no fundo, traduz-se no "fetichismo da mercadoria"231, que nada mais é do que a troca entre coisas, visando a realização de seu "caráter social".

Aqui é preciso fazer breve parênteses a fim de buscar as origens do capitalismo ou, se quiser, a indagação pode ser formulada nos seguintes termos: de que maneira o capitalismo cindiu os instantes econômico e político, fazendo deste mecanismo uma importante baliza de defesa. Primeiro, as análises voltam-se ao capitalismo comercial enquanto momento ex ante para o capitalismo industrial, dado que estabelece as condições necessárias para o apogeu deste ao criar os mecanismos de realização da mercadoria. Esse desenvolvimento não pode ser pensado na lógica da linearidade histórica enquanto instância necessária e suficiente para o advento da seguinte, mas ele há de ser pensado, tendo em mente o alerta de Emir Sader ${ }^{232}$, assentado em Marx, pois, "mesmo quando a circulação parece impor-se ao processo

\footnotetext{
${ }^{231}$ Esse conceito é ilustrado na seguinte passagem do Capital: "Se as mercadorias pudessem falar, diriam: Nosso valor de uso pode interessar aos homens. Não é nosso atributo material. O que nos pertence como nosso atributo material é nosso valor. Isto é o que demonstra nosso intercambio como coisas mercantis. Só como valores de troca estabelecemos relações umas com as outras." Dessa fala, tendo em mente o horizonte da sociedade burguesa, na qual se produz para troca, permitindo, assim, o pleno desenvolvimento da forma mercadoria, é mister, na esteira dos ensinamentos de Marx, extrair duas considerações relevante ao tema do fetichismo: uma versa sobre o "caráter misterioso da mercadoria"; a outra, sobre a necessidade social. Quanto ao caráter misterioso da mercadoria, ele não tem nada a ver com o seu valor de uso nem com o fator determinante da magnitude do valor (quantidade de trabalho), de modo que esse qualificativo só pode vir da própria forma mercadoria, pois é ela quem oculta "as características sociais do próprio trabalho dos homens, apresentado-as como características materiais e propriedades sociais inerentes aos produtos dos trabalhos; por ocultar, portanto, a relação social entre os trabalhos individuais dos produtores e o trabalho social, ao refleti-la como relação social existente, à margem delas, entre os produtos do trabalho se tornam mercadorias, coisas sociais, com propriedades perceptíveis e imperceptíveis aos sentidos". Faz com que, desse modo, a realidade seja captada pelo seu reverso, na qual os trabalhos isolados dos homens apareçam como relações entre coisas, ou melhor, como relação de valor entre elas. Quanto à segunda consideração - a necessidade social - os diferentes produtos dos trabalhos humanos são igualados, como valores, na troca de acordo com a qualidade comum de trabalho humano. Essa conversão de coisa útil em valor é uma criação social necessária que passa despercebida pelos homens, isso porque numa sociedade pautada na produção voltada para troca, na qual cada trabalho privado é parte componente do trabalho social, é irrelevante saber que os produtos trocados são, na verdade, relações entre homens, pois esse saber em nada modifica o seu funcionamento. Assim, ter consciência da realidade - "produtos do trabalho como valores serem meras expressões materiais do trabalho humano despendido" - não afasta a "fantasmagoria" que apresenta o caráter social do trabalho. "O que é verdadeiro apenas para essa determinada forma de produção, a produção de mercadorias - a saber, que o caráter social especifico dos trabalhos particulares, independentes entre si, consiste na identidade deles como trabalho humano e assume nos produtos a forma de valor -, parece aos produtores de mercadorias tão natural $e$ definitivo, apesar daquela descoberta, quanto o ar, que continuou a existir tal como era antes, após a ciência têlo decomposto em seus elementos. O que, na prática, interessa aos que trocam os produtos é saber quanto de outras mercadorias podem receber pela sua; em que proporções, portanto, os produtos se trocam”. Marx, Karl. O capital: crítica da economia política. Livro I. Trad. Reginaldo Sant Anna. 26 ${ }^{\mathrm{a}}$ Ed. Rio de Janeiro: Civilização Brasileira, 2008, p. 92/105 ver principalmente p. 94,96 e 104.

${ }^{232}$ Estado e política em Marx...Op. Cit., p.27 e 29.
} 
produtivo, seu papel de veículo, de instrumento desse processo permanece porque é o caráter da produção, voltada para valores de uso, que lhe possibilita essa substantivação e lhe determina essa tarefa. E, ao mesmo tempo, a primeira troca existente já desvia o rumo da produção, fazendo do comércio seu servidor".

Nas sociedades pré-capitalistas, a sociabilidade realiza-se pela incindibilidade dos instantes econômico (precipuamente o comércio) e político, como mecanismo de conversão do produto excedente em mercadoria, determinando a relação entre os interesses individuais e gerais distinta daquela presente no capitalismo, na medida que não se aventa para as condições privadas dos indivíduos. Isso porque, o móbil das sociedades pré-capitalistas lucro comercial, ou melhor, a produção em função do uso - difere do móbil da sociedade capitalista, porquanto seu mecanismo de reprodução não se encontra na produção guiada pelo valor de troca, mas sim do mecanismo D-M-D'.

Este sistema, em razão da sua impossibilidade autopoietica, só se sustenta na presença de um elemento externo reservado à política, seja ela posta nas relações coloniais entre países ou então nas relações de servidão, de escravidão ou, ainda, de violência contra os pequenos proprietários rurais, vide o exemplo do cercamento inglês (enclosures) dos séculos XVI e XVII, ilustrado na frase "os carneiros estão comendo homens". Por essa razão, é mais do que oportuna a constatação de Emir $\operatorname{Sader}^{233}$ que "quanto mais vigoram formas políticas de apropriação, menos presente está o capitalismo, porque ele substitui essas formas pela troca de equivalente no mercado, onde um mecanismo propriamente econômico - mais valia - se encarrega de alimentar o sistema: as mercadorias se trocam pelo seu valor, e a força de trabalho é trocada - pretensamente sob a forma de equivalente também - pelo salário."

Agora, nas sociedades capitalistas, a vida econômica cinde-se à vida política. Isso se dá, pois o capitalismo tem como fator distintivo com relação aos outros modos de produção a separação entre os meios de produção e força de trabalho, derivando daí o trabalho assalariado que autoriza o não pagamento do trabalho excedente. "Tanto o trabalho pago como o nãoretribuído aparecem como pagos, exatamente ao contrário do trabalho escravo. A introdução das relações capitalistas de trabalho representa, pois, o fim das formas palpáveis de apropriação política, fornecendo a base material que sustenta a ideologia da liberdade e da igualdade; tudo o que contribui para a instauração dessas relações colabora para o enfraquecimento das relações políticas." 234

\footnotetext{
${ }^{233}$ Estado e política em Marx...Op. Cit., p.29.

${ }^{234}$ Sader, Emir. Ibid, p.43.
} 
Estas mesmas relações políticas, que eram outrora o centro do mecanismo de apropriação do excedente econômico, passam nas sociedades capitalistas a exercer outra função (a ideológica) em outro local (afastado das relações econômicas de produção). Sob a figura do cidadão erigido na base da liberdade e da igualdade de uns para com os outros, a política toma agora os indivíduos uniforme e isoladamente considerados, "privando-os de captar as determinações que os produzem enquanto membros das classes sociais ",235.

Cabe de plano uma observação, o fenômeno acima descrito, em apertada síntese, não significa dizer que a política e, em especial, o Estado passam a ser dispensáveis; ao contrário, esta assertiva é demovida por observações de três ordens: a primeira remete ao capitulo I desta dissertação, no item pertinente ao Desenvolvimento do Estado no século XIX, de onde se depreende a fundamentalidade deste para a consolidação do sistema capitalista. As outras duas serão abordadas no Capitulo III, mas, desde já, podem ser elencadas: o papel decisivo do Estado seja para a revolução burguesa nos países subdesenvolvidos ou então o seu papel nos momentos de crise do sistema. Esses singelos apontamentos, na verdade, são representativos dos limites do sistema capitalista, de modo que se pode vislumbrar o Capital ${ }^{236}$ para além de uma relação econômica pensada linearmente na base de um economicismo qualquer, e vê-lo como uma organização social histórica da atividade produtiva estabelecida a partir de uma organização de poder, adstrita a uma organização política, cuja expressão se dá em torno dos direitos de propriedade que quantificam as relações de dominação. Colhe-se, desta maneira, o âmago do sistema capitalista enquanto "configuração política da sociedade" na qual é factível "a expropriação do produtor direito, a manutenção da propriedade privada e o controle sobre a produção e a apropriação".

Feitas estas primeiras considerações, pode-se dirigir ao primeiro momento da troca realizado na esfera da produção que é informada por uma condição prévia e primordial, a saber: a liberdade da força de trabalho separada dos meios de produção, possibilitando não só o primado do objeto sobre o sujeito e, por conseguinte, a alienação deste, como também a elevação da esfera econômica a elemento “dominante e determinante”, uma vez que a autopoiese das relações sociais se perfaz no interior do processo de produção e também possibilita ao homem "dispor de si mesmo" como uma mercadoria. Por mais paradoxal que possa parecer, no entanto, não se pode perder de vista que a esfera da produção se nutre de uma "dupla troca" realizada em suas extremidades: a ponta final tem como objetivo último a realização da mais valia pela circulação; troca esta somente possível se houver uma troca

\footnotetext{
${ }^{235}$ Sader, Emir. Estado e política em Marx...Op. Cit., p.46.

${ }^{236}$ Wood, Ellen Meiksins. Democracia contra capitalismo...Op.Cit., p. 31 e 33.
} 
precedente, inicial: a da força de trabalho por salário, autorizando a separação entre trabalho necessário e trabalho excedente, propiciando o não pagamento do último. $\mathrm{O}$ instante primeiro da dupla troca é fulcral para o sistema e engendra uma dupla passagem: seja da força de trabalho em mercadoria ou do excesso de trabalho em mais valia, a serem vislumbradas a seguir.

Se o primeiro aspecto da liberdade, oriundo da cisão entre os meios de produção e a força de trabalho, eiva o homem de opções, visto que não lhe é dado à alternativa de produzir e de vender sua própria mercadoria, esta mesma liberdade o dirige para a segunda liberdade, a única possível, qual seja: a de se oferecer no mercado em igualdade de condições com o comprador de sua capacidade de trabalho. Sendo assim, a esfera da produção "empurra" o trabalhador à esfera da circulação, informada por relações de troca entre "possuidores de mercadorias" mas que, na verdade, abriga o momento antecedente: o processo de produção e as relações de classe, permitindo, desse modo, que a esfera da circulação possa "aparecer como um verdadeiro éden dos direitos naturais do homem, no qual as determinações jurídicas da liberdade e da igualdade permitem que essa relação de capital apareça como um resultado de um livre acordo de vontades celebrado sob a base da troca de equivalente. "237

Deitando-se, mais detalhadamente, sobre a relação de troca, de acordo com Balibar $^{238}$, ela exibe numa ponta o econômico (objeto - mercadoria) e na outra, o jurídico (sujeito - sujeito), que se aproximam "na equivalência generalizada que submete os indivíduos à forma de uma circulação - seja de valores ou de obrigações"e que se destacam, na medida que o econômico, sob a forma de objeto ou valor, carreia uma "individualidade exteriorizada"; e o jurídico, na figura do sujeito, mais especificamente, de sua vontade, remete a uma "individualidade interiorizada".

Essa diferença não repele o instante econômico do jurídico, pelo contrário, ela é justamente o complemento de que precisa a relação para lograr sua unidade. Se para a economia, assentada no primado da coisa, o relevante é a possibilidade de circulação do objeto para a realização de seu valor de troca, a pergunta elementar é saber como isso se processa, a partir da noção de que as coisas, ontologicamente, são diversas. A resposta para se perfazer a universalidade da troca é a busca e obtenção de uma medida comum, um parâmetro capaz de estabelecer uma proporção para a troca, logrado pela passagem do concreto da coisa a seu abstrato - forma mercadoria - pois é ela "um objeto no qual a diversidade concreta das

\footnotetext{
${ }^{237}$ Naves, Márcio Bilharinho. Marx. Ciência e revolução...Op. Cit., p. 64.

${ }^{238}$ Balibar, Étienne. A filosofia de Marx, 1995, p. 89 apud ALMEIDA, Silvio Luiz de. O direito no jovem Lukács...Op. Cit., p.118/119.
} 
propriedades úteis torna-se, simplesmente, o invólucro coisificado da propriedade abstrata do valor, que se exprime como capacidade de ser trocada em uma proporção determinada em relação a outras mercadorias ". 239

Na outra ponta da troca, o direito "se opõe" à economia pela submissão da coisa a vontade humana. Ele logra, no entanto, a obtenção de sua medida comum pelo mesmo modus operandi da economia, qual seja: a passagem do concreto ao abstrato só que agora a pessoa concreta é substituída pela forma sujeito de direito. De fato, o sujeito é o reflexo da mercadoria - seu igual oposto, pois “assim como a diversidade natural das propriedades úteis de um produto só aparece na mercadoria sob a forma de simples invólucro de seu valor e como as variedades concretas do trabalho humano se dissolvem no trabalho humano abstrato, como criador de valor, igualmente a diversidade concreta da relação homem com a coisa aparece como vontade abstrata do proprietário e todas as particularidades concretas, que distinguem um representante da espécie Homo Sapiens de outro, se dissolvem na abstração do homem em geral, do homem como sujeito de direito.",240

Ou seja, a aparente contradição entre economia e direito é resolvida na própria relação de troca pela dupla abstração - do objeto em mercadoria e da pessoa em sujeito. A abstração jurídica permite o surgimento da igualdade ao nivelar todos - no sentido de que se reconhecem como semelhantes e como não dependentes entre si na base comum do capitalismo, qual seja: na capacidade de todos serem portadores do direito de propriedade, pois "é apenas como proprietário que ele se torna igual, porque entre as formas de proprietários abstratos não há qualquer diferença. E é apenas como proprietário que ele se torna livre, porque cada um é proprietário da sua coisa e não depende de mais ninguém.", 241

A equiparação do homem ao sujeito de direito traz consigo sua essencialidade - a de ser portador de mercadorias - e, no limite, investe-o na qualidade de proprietário de si mesmo e, em particular, do único bem que lhe é outorgado pela realidade objetiva - a de ser proprietário de sua força de trabalho. "Assim, ao mesmo tempo em que, do ponto de vista econômico, o trabalho se torna mercadoria ao ser reduzido a uma forma abstrata, do ponto de vista do direito, o homem é reduzido à forma do sujeito de direito e se torna proprietário de uma mercadoria que é ele mesmo. A constituição do homem como sujeito de direito é, portanto, ao mesmo tempo, a sua constituição como objeto de direito." 242

\footnotetext{
${ }^{239}$ Pasukanis, E.B. Teoria Geral do Direito e Marxismo...Op. Cit., p.84.

${ }^{240}$ Pasukanis, E.B. Ibid, p.86.

${ }^{241}$ Kashiura Júnior, Celso Naoto. Crítica da igualdade jurídica - Contribuição ao pensamento jurídico marxista. São Paulo: Quartier Latin, 2009, p. 63.

${ }^{242}$ Kashiura Júnior, Celso Naoto. Ibid, p. 64.
} 
Opera-se, nesses termos, a passagem da força de trabalho em mercadoria por intermédio da forma jurídica - sujeito de direito - que é capaz de per si, espontânea e voluntariamente, dirigir-se ao mercado a fim de encontrar o seu igual - outro sujeito, com intuito de trocar as mercadorias. Esse é o limite da esfera da circulação e, por consequência, da economia política que não deixa antever, pela estreiteza de seu método, a passagem do excesso de trabalho em mais valia - exploração do trabalhador no processo de produção capitalista instrumentalizado com base em uma forma jurídica ímpar, de natureza subjetiva e privada.

Nesse instante, a figura do contrato apresenta se vivamente, pois se o sujeito de direito informa o conceito de proprietário da mercadoria, é pela via do contrato que esse mesmo sujeito acessa o mercado para se pôr em circulação, de modo que o direito age sob o momento mais delicado do capitalismo - na troca dos equivalentes: força de trabalho e salário. Assim, é pelo contrato enquanto pacto que se erige pelas equivalências em ambas as pontas, econômica ou jurídica, que a separação originária entre a força de trabalho e os meios de produção se reconcilia, só que agora em um patamar diferenciado - o da igualdade, a despeito da diferença entre as mercadorias de cada um.

A pergunta imediata que se põe é qual o denominador comum a fim de tornar factível essa equivalência? Aqui há de se remontar aos ensinamentos de $\operatorname{Marx}^{243}$ e, em especial, ao tratamento da mercadoria na base do valor de uso e do valor de troca e de sua derivação para a compra e venda da força de trabalho. Pois bem, dentre as mercadorias, o valor de uso expressa grandezas qualitativamente diversas, pois nada mais é do que a utilidade de um bem advindo de sua própria natureza; o valor de troca exprime grandezas quantitativamente diferentes, na medida em que é a abstração do valor de uso da mercadoria.

Essa última aproximação não dá ainda o elemento comum dentre todas as mercadorias, pois não se pode explicar a igualdade estabelecida na troca entre x quantidades do produto A por y quantidades do produto B. A grandeza a autorizar a troca há de ser necessariamente uma terceira que, simultaneamente, esteja presente nas duas coisas e que delas seja diferente. $\mathrm{O}$ traço comum a todas as mercadorias está no fato de serem todas elas trabalho humano abstrato, pois se é factível prescindir do valor de uso da mercadoria para as relações de troca é plausível do mesmo modo desvencilhar-se das diferentes formas de trabalho concreto presentes nesses produtos. Sendo assim, a troca se engendra realmente pelo

${ }^{243}$ Marx, Karl. O capital...Op. Cit., p.57/63. 
que tem de comum, ou seja, pelo valor das mercadorias, valor esse mensurado pela quantidade de trabalho dado em função do tempo.

Até aqui se limitou ao âmbito da circulação, cuja troca há de necessariamente pautar-se pela equivalência entre as mercadorias, equivalência esta obtida pelo trabalho nela contido. Agora, há de se verificar se na compra e venda na esfera da produção, fundamental do sistema capitalista, a equivalência entre salário e força de trabalho opera-se da mesma forma.

Formalmente, o princípio da equivalência é respeitado nesse contrato específico, pois o valor da força de trabalho ${ }^{244}$, como qualquer mercadoria, é dado em função do tempo de trabalho necessário à sua produção e, por conseguinte, à sua reprodução - extensão das necessidades consideradas indispensáveis por uma sociedade dada na razão das condições históricas de um determinado país que remetem ao seu grau de desenvolvimento, bem como da sua classe trabalhadora. Isto, de per si, é um indício relevante para explicitar as diferenças dos valores da força de trabalho nas diversas partes do globo e nos diferentes momentos da humanidade, considerando os países individualmente, diferenças essas que se materialização, também, no quantum de direitos sociais ali presentes.

Para além dos aspectos espacial e temporal, existem pelo menos duas características particulares da mercadoria força de trabalho, a saber: uma delas reside na especificidade do contrato $^{245}$, no qual existe uma dissonância, normalmente, de 30 dias, entre os tempos da alienação da força de trabalho e de seu uso pelo comprador, ou seja, o trabalhador invariavelmente é credor de seu empregador ao adiantar-lhe o valor de uso da força de trabalho, permitindo, assim, seu consumo. A outra, essencial, reside na discrepância entre o valor da força de trabalho e sua colocação em valor no processo produtivo, isto advém do fato de que a força de trabalho é uma mercadoria sui gênesis na medida que, quando incorporada em um produto tem a singularidade de ser "criadora de valor", fonte da "mais valia".

Na verdade, o vendedor da força de trabalho na troca com o detentor dos meios de produção, como em toda e qualquer compra e venda, aliena seu valor de uso e realiza seu valor de troca; a particularidade está no fato de que essa mercadoria é adquirida pelo dia todo e paga por meio dia; a diferença - trabalho humano não pago - não infere a relação de equivalência, mostrando-se apenas como uma vantagem ao comprador, sem representar uma desvantagem ao vendedor. ${ }^{246}$

\footnotetext{
${ }^{244}$ Marx, Karl. O capital...Op. Cit., p.200/201.

${ }^{245}$ Marx, Karl. Ibid, p. 204/206.

${ }^{246}$ Marx, Karl. Ibid, p. 226/227
} 
Então, o momento nuclear do sistema reside justamente no "processo de valorização do capital" que se opera pela dissonância entre os valores - "da força de trabalho e sua valorização", pois o basilar localiza-se no valor de uso peculiar dessa mercadoria que é ser "fonte de valor e de mais valor do que ela mesma tem". Na prática, tudo se perpassa sob os auspícios do princípio da troca de equivalentes que informa o instante da compra e venda desta mercadoria única, velando, desse modo, o "sobre-produto" - mais valia. ${ }^{247}$

Denota-se, desse modo, a "transformação do dinheiro em capital", realizada tanto na esfera da circulação "via condicionamentos da compra da força de trabalho no mercado" como fora dela, na medida que essa transformação introduz "o processo de valorização que ocorre na esfera da produção". Ao incorporar essa força de trabalho viva à materialidade morta dos meios e do objeto de trabalho, "transforma-se valor, trabalho pretérito materializado, morto em capital, em valor que se amplia, um monstro animado que começa a trabalhar, como se tivesse o diabo no corpo". ${ }^{248}$

Dirigindo-se ao fim do tópico, cabe marcar duas considerações: a primeira é bem singela e retirada de pronto do exposto acima. A diferença entre produzir valor e mais valia é apenas gravada pela temporalidade, pois ultrapassado determinado marco, por exemplo, meiodia, valor e mais valia se confundem. A segunda requer tal como se processou com a mercadoria vislumbrar o trabalho na dicotomia valor de uso e valor.

Aquele é apenas o trabalho útil considerado qualitativamente, segundo seu objetivo e conteúdo a produzir valores de uso. Este é o mesmo trabalho só que considerado quantitativamente importando apenas o tempo gasto para realizar uma determinada tarefa. Essa diferença é relevante para assinalar o processo de produção em dois de seus aspectos: “o processo de produção, quando unidade do processo de trabalho e do processo de produzir valor, é processo de produção mercadorias; quando unidade do processo de trabalho e do processo de produzir mais valia, é processo capitalista de produção, forma capitalista da produção de mercadorias". ${ }^{249}$

O intuito do item, para além do seu modus operandi, foi o de sinalizar a "pureza" e o "asseio" da trajetória narrada, porquanto a apropriação da mais valia por outrem é uma condição interna ao processo produtivo, tornando prescindível qualquer modalidade de coação externa ou explícita, na medida que a necessidade obriga o trabalhador a relacionar-se com o

\footnotetext{
${ }^{247}$ Naves, Márcio Bilharinho. Marx. Ciência e revolução...Op. Cit., p. 65/66.

${ }^{248}$ Marx, Karl. O capital...Op.Cit., p. 228.

${ }^{249}$ Marx, Karl. Ibid, p.230.
} 
capitalista, a fim de acessar os meios de produção, via mecanismo de intercâmbio de mercadorias instrumentalizado pelo contrato entre sujeitos livres. ${ }^{250}$

Este aspecto do sistema capitalista, ${ }^{251}$ pautado pela diferenciação das esferas econômica e política, redunda em duas ordens distintas de poder - o de classes e o do Estado. Isso se dá, pois os momentos de produção e apropriação (do excedente) concentram-se no âmbito privado, caracterizando-se, assim, a retirada do elemento político e sua remessa ao Estado. E este, agora, passa a intervir no conflito de forma mediata de modo que a questão central - apropriação do excedente - deixa de ser um fator de coação política imediata. E mais, essa dicotomia traz duas consequiências, abordadas mais à frente: i) retira do âmbito privado qualquer responsabilidade no tocante ao tratamento da questão social e ii) remete o foco da disputa de classes para questões em torno da organização da produção, mais especificamente, das condições de trabalho.

De fato, o que o processo todo está a indicar é a cisão da própria função política em dois instantes autônomos - um para a esfera econômica privada e o outro para a esfera pública do Estado, com o distintivo de que esta última a todos pertence, desde que respeitada outra esfera - local onde reside o poder de exploração pela integração total entre a organização da produção e da expropriação. Em suma, "as funções sociais de produção e distribuição, extração, apropriação de excedentes, e a alocação do trabalho social são, de certa forma, privatizados e obtidos por meios não autoritários e não políticos. (...) e é isso exatamente o que significa dizer que o capitalista tem poderes econômicos, e não extra-econômicos, de exploração." 252

O espelho do lado dito "produção social" é o da "renda social" que mostra as funções da moeda ${ }^{253}$, ressaltando sua instrumentalidade ao permitir o acesso ao mercado. Isto ocorre, pois há uma migração da "forma inferior" à "forma superior" de troca, ao cindir o ato de troca em dois atos de compra e venda: em um primeiro momento apenas uma das partes apenas tem por satisfeita sua necessidade, enquanto a outra parte é delegada uma satisfação futura em virtude da posse da moeda.

\footnotetext{
${ }^{250}$ Wood, Ellen Meiksins. Democracia contra capitalismo... Op.Cit., p. 34/35.

${ }^{251}$ Wood, Ellen Meiksins. Ibid, p.38, 46, 47.

${ }^{252}$ Wood, Ellen Meiksins. Ibid, p.35 e 43.

${ }^{253}$ Conceito de moeda - produto da ordem jurídica, cuja unidade de valor que permite quantificar pagamentos, atribuindo validade a essa utilização. Procura efetiva - procura instrumentalizada por moeda. Liquidez - posse de disponibilidades monetárias com vistas a autorizar o seu titular a adquirir bens e serviços no mercado. Poder de compra - Expressão do valor real da moeda qualificado pelo atributo de reserva de valor e de parcela de poder. Chiara, José Tadeu de. A moeda e a ordem jurídica. 1986. 217 f. Tese (Doutorado em Direito Econômico) - Faculdade de Direito, Universidade de São Paulo, São Paulo, 1986, p. 24, 28, 30, 57, 59/61, $73 / 79$.
} 
Daí se extrai a "multilateralidade da relação", para além das partes envolvidas, constituindo-se em um a "bilateralidade interna" somada a "multilateralidade externa" que se traduz em "procura efetiva e liquidez". De modo que os "titulares de maior ou menor disponibilidade monetária" agem influenciando a dinâmica dos mercados, afetando as "situações de liquidez e de procura efetiva".

Aqui reside o traço distintivo do sistema capitalista ao investir o proprietário da moeda em uma situação de liquidez, outorgando-lhe, ao mesmo tempo, uma vantagem e um privilégio que o autoriza a atuar nas relações de troca/jurídicas, de onde se retira a dominação que é, simultaneamente, poder e influência dirigidos à ação, inerentes à ordem jurídica qualificada pelo poder de compra (liquidez e procura efetiva).

\section{2) Momento circulação $-2^{\mathrm{a}}$ troca}

O momento produção, didaticamente separado da circulação, teve por objetivo preparar o terreno para análise da relação Capital e Trabalho e de suas decorrências que se processarão no item 3 deste capítulo, bem como no capítulo seguinte, procurando não deixar dúvidas de que a equivalência ali realizada é, na verdade, uma não equivalência e que essa mesma não equivalência de modo algum será captada no instante seguinte - o da circulação. O último ponto, ora examinado, ficará claro ao abordar os limites dos direitos sociais e dos direitos do consumidor e para tal empreitada é importante fixar, a partir de Pasukanis, os conceitos de sujeito de direito e de relação jurídica.

Primeiramente, cabe esclarecer que remontar a Pasukanis, no item intitulado de circulação, poderia dar a impressão de que o autor é um "circulacionista" a objetar tudo o antes dito neste capítulo. Com vista a evitar tal interpretação, algumas elucidações a partir do próprio Pasukanis são pertinentes e relevantes para o tema. $\mathrm{O}$ autor estabelece não apenas o primado da relação jurídica frente à norma, acompanhado mediatamente no item precedente, como também ele avança para escrutiná-la, na medida que afirma que a relação jurídica nada mais é do que uma relação entre sujeitos, onde estes são "o átomo da teoria jurídica, seu elemento mais simples indecomponível". ${ }^{254}$ A perspectiva, de início, inverte a relação direito objetivo/subjetivo, tornando este o instante anterior àquele, na medida que o direito subjetivo $^{255}$ tem por base os "interesses materiais independentes de toda e qualquer regulamentação externa da vida social", dado que "todo proprietário compreende bem o

\footnotetext{
${ }^{254}$ Pasukanis, E.B. Teoria geral do direito e o marxismo...Op. Cit., p.81

${ }^{255}$ Pasukanis, E.B. Ibid, p.69/71.
} 
direito que lhe assiste enquanto proprietário", distanciando-se da ideia de obrigação (direito objetivo). Referência, a contrário sensu, pode-se extrair ao fazer uma incursão em Kant quando ele teoriza as posses natural e jurídica.

Esta dupla inversão, perpetrada por Pasukanis, no direito, remete às condições reais de produção $^{256}$ presentes na sociedade capitalista em seus dois momentos históricos relevantes, a saber: i) ampliação dos "vínculos sociais" que leva a transformação do valor de troca em categoria econômica; ii) a "organização social em torno das classes", cuja expressão máxima reside no Estado de Direito, de forma que o direito espelha o instante da troca, uma vez que tem a matriz de seu movimento na economia mercantil. Pois, se na esfera da circulação, o direito apresenta-se como elemento possibilitador da igualdade frente à realidade do feudalismo; é, na esfera da produção, que esse mesmo direito ratifica sua condução de indutor da igualdade, agora em uma acumulação exponencial da propriedade privada ${ }^{257}$.

Esses apontamentos são indiciários por si só de que a determinação do direito em Pasukanis transcende a tese da circulação, indo para uma determinação complexa que compreende o direito pelas relações de produção como um de seus momentos constitutivos. Esta celeuma é arrematada por Bilharinho ${ }^{258}$ quando afirma que o ponto relevante para a concepção do direito em Pasukanis reside no fato de que a esfera da circulação determina a forma jurídica, mas a relação não se limita a este extrato, pois há uma determinação, de segundo grau, na qual a forma jurídica decorre da instauração das relações de produção.

Finda a curta digressão em torno do assunto Pasukanis e circulação, é factível, agora, retomar a convergência entre economia e direito, na qual se verifica que as relações sociais de produção e a continua e sistemática circulação de mercadorias propiciam as condições necessárias ao surgimento do conceito sujeito de direito e contribuem, decisivamente, para a passagem do homem concreto ao abstrato e impessoal, adquirindo, assim, a "significação de um ponto matemático, de um núcleo no qual se concentra certo número de direitos". 259

O duplo desenvolvimento - seja da propriedade jurídica, mas sobretudo do sujeito significa, em última instância, que a forma jurídica em seu estágio desenvolvido, tem sua correspondência nessas relações sociais capitalistas, pois nela amalgamam-se a propriedade como bem de livre disposição no mercado e o sujeito enquanto elemento reprodutor da ideia da liberdade, de modo a equiparar "os proprietários de mercadorias a sujeitos livres e iguais entre si”. Tal é o distintivo da modernidade para com a vida pregressa onde "o escravo é

\footnotetext{
${ }^{256}$ Pasukanis, E.B. Teoria geral do direito e o marxismo...Op. Cit., p. 87/88.

${ }^{257}$ Mascaro, Alysson Leandro. Para uma crítica da legalidade no Brasil contemporâneo...Op. Cit., p.25 e 27.

${ }^{258}$ Marxismo e direito...Op. Cit., p. 72/73.

${ }^{259}$ Pasukanis, E.B. Teoria geral do direito e o marxismo...Op. Cit., p. 88.
} 
totalmente subordinado ao seu senhor e é precisamente por esta razão que esta relação de exploração não necessita de nenhuma elaboração jurídica particular. O trabalhador assalariado, ao contrário, surge no mercado como livre vendedor de sua força de trabalho e é por isso que a relação e exploração capitalista se mediatiza sob a forma jurídica de contrato". 260

A sociedade capitalista se apresenta, nesse sentido, como "sociedade de proprietários de mercadoria", ${ }^{261}$ cujas relações sociais no processo de produção apresentam-se nos seus produtos de trabalho reificados e valorados uns em relação aos outros, a fim de facilitar sua circulação no mercado. O valor dessa mercadoria tem dois aspectos relevantes, a saber: i) independe da vontade do sujeito que a produz; ii) pressupõe um ato voluntário por parte de seu proprietário no processo de troca. Eis aí a importância dos possuidores, pois "não é com seus pés que as mercadorias vão ao mercado, nem se trocam por decisão própria. Temos, portanto, de procurar seus responsáveis, seus donos. As mercadorias são coisas; portanto, inermes diante do homem. Se não é dócil, pode o homem empregar força, em outras palavras, apoderar-se dela". ${ }^{262}$

O último tópico é o elemento decisivo da categoria de sujeito de direito, sob a qual se engendram os atributos liberdade e igualdade, características fundamentais à esfera da circulação mercantil. Portanto, "é na esfera da circulação das mercadorias, como um elemento dela derivado que opera para tornar possível a troca mercantil, que nasce a forma jurídica do sujeito" 263 e, sob a forma de sujeito, o homem faz circular a si mesmo, como objeto de troca, e esta condição é aquela em que ele realiza a liberdade.

Assim, o vínculo social entre homens no processo de produção para se perfazer necessita de uma relação entre eles seja enquanto "indivíduos que dispõem de produtos", seja "enquanto sujeitos cuja vontade habita nas próprias coisas" de forma que essa dualidade reflete-se nos bens produzidos em dois instantes distintos: i) no trabalho; ii) na troca. "Eis por que, ao mesmo tempo em que o produto do trabalho reveste as propriedades da mercadoria e torna-se portador de valor, o homem torna-se sujeito de direito e portador de direitos". ${ }^{264}$

Essa relação tem por forma justamente o contrato $^{265}$, que "é uma relação de vontade em que se reflete a relação econômica", na medida em que possibilita o reconhecimento das pessoas enquanto "possuidores de mercadorias". Sua singularidade está na equiparação entre

\footnotetext{
${ }^{260}$ Pasukanis, E.B. Teoria geral do direito e o marxismo...Op. Cit .,p. 82.

${ }^{261}$ Pasukanis, E.B. Ibid, p. 84.

${ }^{262}$ Marx, Karl. O capital...Op. Cit.,p.109.

${ }^{263}$ Naves, Márcio Bilharinho. Marxismo e direito...Op. Cit., p. 65.

${ }^{264}$ Pasukanis, E.B. Teoria geral do direito e o marxismo...Op. Cit., p. 84/85.

${ }^{265}$ Naves, Márcio Bilharinho. Marxismo e direito...Op. Cit., p. 66/67.
} 
as "equivalências subjetiva e objetiva", permitindo "a troca de mercadorias na base da lei do valor", ao autorizar o grau máximo de liberdade, que é o homem como mercadoria, aproximando-se, assim, o sujeito do objeto. Se quiser, em outros termos, a vida social $^{266}$ é construída, simultaneamente, pela "totalidade de relações reificadas", nas quais os homens são as próprias coisas dotadas de valor mercantil e pela "totalidade de relações existentes" entre o homem e a coisa, nas quais os homens são sujeitos de direito. Portanto, as relações entre os homens no processo de produção são, simultaneamente, relações entre coisas (mercadorias) e relações de vontade informadas pelo sujeitos de direito.

Aliás, a relação do mercado ${ }^{267}$ transforma a "oposição sujeito/objeto em sua significação jurídica" na medida em que "o fetichismo da mercadoria é completado pelo fetichismo jurídico". Tal processo se perfaz da seguinte forma: o objeto é a mercadoria, o sujeito é o proprietário dessa mercadoria, que se manifesta no ato de troca "a plenitude de suas determinações". Logo, o conceito de sujeito de direito finda-se por se resumir à capacidade jurídica pautada na vontade em torno do direito subjetivo, pois este é um "fenômeno social que é atribuído ao indivíduo da mesma forma que o valor, outro fenômeno social, é atribuído à coisa enquanto produto do trabalho".

Uma vez que o direito subjetivo fora mencionado, não se pode olvidar que ele, como direito da pessoa, amalgama a relação "vontade-liberdade" pela redução desta àquela na via consentimento no instante da formação contratual - "eu devo as minhas relações com o outro aparecer como proprietário de mim mesmo porque sou livre de mim mesmo." ${ }^{268} \mathrm{Na}$ linha do texto - da equiparação pessoa à propriedade - a estrutura do sujeito de direito reproduz a "dialética da vontade - produção - propriedade” cuja tradução final é a "comercialização do próprio homem".

Esse basicamente o fenômeno é verificável na completude do desenvolvimento das relações burguesas, em que "cada homem torna-se um homem em geral, cada trabalho tornase trabalho social útil em geral, cada individuo torna-se um sujeito de direito abstrato. Ao mesmo tempo a norma assume, igualmente, a forma lógica acabada de lei geral abstrata”. ${ }^{269}$ Assim, o sujeito de direito é um proprietário abstrato, cuja vontade é materializada no instante da troca pela figura do contrato, cuja função precípua é potencializar o ato de alienação, seja ele do sujeito ou do objeto, a partir da noção de propriedade. O "reconhecimento recíproco"270

\footnotetext{
${ }^{266}$ Pasukanis, E.B. Teoria geral do direito e o marxismo...Op. Cit., p. 85/86.

${ }^{267}$ Pasukanis, E.B. Ibid, p. 90

${ }^{268}$ Naves, Márcio Bilharinho. Marxismo e direito...Op. Cit., p. 67.

${ }^{269}$ Pasukanis, E.B. Teoria geral do direito e o marxismo...Op. Cit., p. 94.

${ }^{270}$ Pasukanis, E.B. Ibid, p. 95.
} 
nada mais é do que uma tentativa de explicar, por abstrações, as formas orgânicas da sociedade, pois "a relação entre o homem e a coisa é, em si, destituída de qualquer significação jurídica”. O fato é observável quando da construção teórica do conceito de propriedade pela negação, uma vez que ela é elevada à categoria de relação entre sujeitos, "perdendo toda a significação concreta ao se separar de sua própria historia - pré-jurídica" e, para tanto, as justificativas apresentadas por Kant soam de per si suficientes para (não) explicar esse trajeto.

A passagem da relação orgânica para a jurídica entre o homem e a coisa ${ }^{271}$ é fruto do imperativo de se regulamentar a venda e compra em um ambiente de estabilidade e de regularidade, cujo princípio fundante assenta-se na "igual oportunidade de acesso à desigualdade". Assim, apenas o mercado cria a possibilidade de transformação do homem em proprietário jurídico, de modo que o natural transmuta-se ao jurídico à semelhança do "roubo a mão armada ao comércio".

Em um primeiro momento - como condição de uso pessoal e livre - a relação do homem com a coisa representa a forma originária e inicial da realidade humana, rompendo com a origem orgânica da propriedade (família e comunidade) pelo aparecimento da forma universal, como circulo exterior de liberdade, liberdade esta pautada na capacidade abstrata de ser sujeito de direito. Em um segundo momento - como condição de alienação no ato de troca - a simbiose entre o econômico e o jurídico é engendrada pelo fenômeno da troca que consubstancia a circulação de mercadorias. O fato ocorre, pois o econômico tem de valer-se do jurídico para lograr êxito em sua função, ou seja, este existe na medida em que aquele se faz atuante - "O poder ilimitado de dispor da coisa nada mais é do que o reflexo da circulação ilimitada das mercadorias". ${ }^{272}$ Estes dois instantes contribuem para o desenvolvimento da propriedade privada, cujo apogeu tem-se sob a égide do capitalismo.

A propriedade é, então, por excelência, " a liberdade de transformação do capital de uma forma à outra, a liberdade de transferência do capital de um círculo ao outro", ${ }^{273}$ tendo por objetivo obter o maior lucro possível com o mínimo de dispêndio de trabalho. Tal atributo tem por base a distribuição desigual da riqueza social, distribuição esta ratificada pelo direito e, em especial, na forma jurídica da propriedade onde se outorga a todos a condição formal de serem proprietários, "não obstante, não os tornando proprietários."

\footnotetext{
${ }^{271}$ Pasukanis, E.B. Teoria geral do direito e o marxismo...Op. Cit., p. 96/98 e 100.

${ }^{272}$ Pasukanis, E.B. Ibid, p. 98.

${ }^{273}$ Pasukanis, E.B. Ibid, p. 101.
} 
Tecidas as considerações quanto às estruturas básicas do direito - sujeito de direito e o contrato - voltadas para ambos os instantes produção e circulação, sem perder de vista que a mais valia se produz no primeiro, mas que sua realização ocorre apenas no segundo, pode-se ilustrar, agora, o momento da circulação a partir do direito do consumidor $^{274}$, o qual é extensível aos "direitos sociais privatizados" - saúde e previdência, por exemplo. Esse prolongamento se dá na lógica da relação gênero e espécie, seja ela na base da similitude da forma, das condições e dos limites e até mesmo das origens. Os contratos de saúde e de previdência privada nem ao menos são vistos como um "direito social fundamental" mas sim operacionalizados enquanto mais uma relação de consumo. A jurisprudência pátria é farta em exemplos dessa equiparação - para a saúde vide os seguintes julgados a título de ilustração (REsp 251024, Min. Sálvio de Figueiredo Teixeira, DJe 04/02/02; REsp 311509, Min. Sálvio de Figueiredo Teixeira, DJe 25/06/01; REsp 214237, Min. Ruy Rosado de Aguiar, DJe 27/08/01; REsp 171373, Min. Barros Monteiro, DJe 02/08/04; AgRg no Ag 627014, Min. Aldir Passarinho Júnior, DJe 18/04/05; AgRg no REsp 609372, Min. Nancy Andrighi, DJe 01/02/06; REsp 735168, Min. Nancy Andrighi, DJe 26/03/08; REsp 1011331, Min. Nancy Andrighi, DJe 30/04/08; REsp 418572, Min. Luis Felipe Salomão, DJe 30/03/09; AgRg no Ag 1131324, Min. Sidnei Beneti, DJe 03/06/09); para a previdência é suficiente a súmula 321 do STJ - O Código de Defesa do Consumidor é aplicável à relação jurídica entre entidade de previdência privada e seus participantes.

Quanto à forma ${ }^{275}$, ambos se valem da mesma: do contrato, aliás, essa é a maior lição de Pasukanis que estabeleceu o vínculo indissociável entre a forma jurídica e a forma mercantil, que, no limite, equipara a estrutura do direito moderno à do capitalismo, pois com base na forma jurídica é possível a estruturação das relações econômicas capitalistas a despeito do seu conteúdo.

Quanto às condições, elas remontam à noção de hipossuficiência, pois nada mais são do que o reconhecimento jurídico da insuficiência da igualdade formal absoluta, a qual não é rechaçada e sim reafirmada por uma segunda espécie de igualdade formal - a relativa na base da equidade aristotélica - tratar os iguais igualmente e os desiguais desigualmente na medida que se desigualam - "a pretensa nova forma da igualdade jurídica seria não mais a da universalidade da ignorância, mas a da composição da diversidade. (...) A partir da igualdade indeterminada deveria ser elaborada um rol de igualdades determinadas, ou seja,

\footnotetext{
${ }^{274}$ Kashiura Júnior, Celso Naoto. Crítica da igualdade jurídica...Op.Cit., p. 151/176. Ver principalmente pg. 160, 170,171 e 173.

${ }^{275}$ Mascaro, Alysson Leandro. Introdução ao estudo do direito...Op.Cit., p.14/16.
} 
o reconhecimento de certas diferenças e peculiaridades sociais dos homens que, uma vez devidamente medidas e balanceadas juridicamente, permitiriam a efetivação da igualdade em maior grau do que o atingido pelo mero principio da igualdade." 276

Quanto às origens, tal qual Marx fez a transposição do capitalismo comercial para o industrial a partir da produção, aqui não é diferente, ou seja, não é o consumismo e muito menos a visível discrepância entre consumidor e fornecedor desenvolvida ao longo do curso dos vários momentos do capitalismo, desde o concorrencial até o imperialista que ensejaram o direito do consumidor, mas sua origem há de ser buscada sim na alteração estrutural da esfera produtiva $^{277}$ - fordismo para o toyotismo - bem como de suas derivações, dentre elas: o fomento do consumo na base da publicidade e da venda do desejo, do desemprego estrutural, desmonte do Welfare State e o aparecimento e o apogeu do judiciário como ator relevante, residindo aí a causa última da prevalência do direito do consumidor hoje na sociedade. Isso porque os ganhos de produtividade, concebidos em redução de custos e em avanço da tecnologia, angariados na esfera da produção, que nada mais são do que a tradução do incremento da mais valia e que não podem ser obstaculizados, de forma alguma, por uma dificuldade ínsita à esfera da circulação.

Quanto aos limites, na verdade, não há limites, e o estado atual da realidade neoliberal é profícuo em referendar tal assertiva, haja vista a amplitude e o domínio angariado pelo direito do consumidor, sabedor de sua tarefa, expressa-a como princípio do CDC no seu artigo 04, inciso III, in verbis: "harmonização dos interesses dos participantes das relações de consumo e compatibilização da proteção do consumidor com a necessidade de desenvolvimento econômico e tecnológico, de modo a viabilizar os princípios nos quais se funda a ordem econômica (art. 170 da Constituição Federal) sempre com base na boa-fé e equilíbrio nas relações entre consumidores e fornecedores".

O princípio do CDC está, em outras palavras, a dizer que consumidor e fornecedor devem, pela alteridade, reconhecer-se mutuamente, em prol de ambos e, sobretudo, do último para o bom funcionamento do sistema. Esse recado do CDC vai ao encontro do apregoado pelo capítulo, pois a esfera da circulação e, em especial, o direito do consumidor ${ }^{278}$ tem, por fim último, ser instrumento facilitador da circulação do capital pelo estabelecimento de um fluxo, sem sobressaltos, das relações de consumo e com a vantagem, ainda, de sequer por, sob judice, a lógica igualitária da forma jurídica, ou então, de transcender da superficialidade do

\footnotetext{
${ }^{276}$ Kashiura Júnior, Celso Naoto. Crítica da igualdade jurídica...Op.Cit., p. 170.

${ }^{277}$ Detalhes maiores podem ser obtidos consultando o item Pós Guerra - Welfare State do capitulo anterior. Ver, ainda, Kashiura Júnior, Celso Naoto. Ibid, p. 160.

${ }^{278}$ Kashiura Júnior, Celso Naoto. Ibid, p. 171.
} 
sistema, pois aqui a questão não é captar a mais valia e sim apenas de realizar a sua potencialidade e como se trata de uma esfera até certo ponto distante do núcleo do sistema, tudo a de ser feito, todos os paradigmas clássicos do liberalismo hão de ser rompidos, para que o capital continue sua "eterna vida" de se auto-reproduzir, desvencilhando-se de eventuais empecilhos que possam aparecer em seu curso.

Raciocínio semelhante, quem diria, pode ser feito até mesmo com o código civil de 2002 que tornou o direito contratual um "direito principiológico" na esteira do dirigismo contratual e da consequente mitigação da autonomia da vontade no âmbito da relação privada engendradas a partir da função social e da boa fé objetiva.

Ambos os princípios, em apertada síntese, deslocam a perspectiva de uma relação contratual do plano interno para o externo, e a alongam para além da mera celebração, atingindo as fases pré e pós-contratuais. Na verdade, esses princípios propugnam por traduzir a antiga igualdade formal absoluta em uma outra igualdade formal, na medida que a primeira provou ser deletéria ao sistema como um todo, porquanto se limitava a uma relação isolada, na qual a exacerbação do egoísmo não tinha limites. Já a segunda por ter um "caráter ético" a contrabalançar o egoísmo individual ela pode ir de encontro a uma relação contratual singular, mas, no fundo, ela funciona como uma proteção e garantia ao funcionamento do sistema como um todo.

Assim, o sistema encontrou um novo patamar de atuação no qual os riscos são diminuídos e a reprodução do capital, como um todo é garantida em detrimento dos capitalistas individualmente pensados. Esta é a engrenagem do direito burguês que, ao apor o primado na forma a despeito de seu conteúdo logra em jurisdicizar, ou seja, em traduzir na linguagem do capital toda e qualquer necessidade deste e em superar todo e qualquer obstáculo que ele venha a se deparar com o seu oposto. Isso vem a referendar a velha ideia de Marx quando analisou a Revoluções em França - "para não perder os dedos, há sempre de se entregar os anéis" - que em linguagem jurídica - "para não abrir mão da forma, há de se estender o conteúdo". 279

Em suma, o que se objetivou mostrar nesse item em associação com o pretérito é a correlação lógica, indissociável e em graus entre o direito, a troca e a produção performada em planos: i) direito e troca de mercadoria propriamente dita; ii) direito e relações de produção, engendrada em uma noção prévia de liberdade, potencializada pela igualdade. A igualdade é ínsita à relação contratual entre "sujeitos de troca" que se "reconhecem

\footnotetext{
${ }^{279}$ Kashiura Júnior, Celso Naoto. Crítica da igualdade jurídica...Op.Cit., p. 173.
} 
mutuamente" sob pena de impossibilitar sua realização. Ocorre que essa relação tem como consectário anterior a liberdade que não é nada mais do que a premente necessidade de se obter mercadoria, fazendo com que a noção de vontade, elementar ao sujeito, desloque-se ao objeto e, assim, assentando, tanto a igualdade como a liberdade na "troca de valores de troca" $^{, 280}$ cujas realizações são, ao fim e ao cabo de tudo, a subjugação dos trabalhadores.

Por último, as elucubrações acima podem ser robustecidas pela mensagem de $\operatorname{Marx}^{281}$ a respeito do real funcionamento e dos limites do direito, porquanto ele trabalha sob a base de uma medida de igualdade - um critério de equivalência (seja ela uma mercadoria ou o tempo de trabalho), a despeito de qualquer verificação das diferenças de capacidades e de necessidades entre os homens, e, assim, ao buscar a sua igualdade resultará, invariavelmente, em uma desigualdade real.

\section{2) Relação entre direitos privado e público}

As observações anteriores de Pasukanis quanto à oposição norma e relação jurídica captaram a primeira dicotomia do direito - direito objetivo e direito subjetivo, apondo o primado neste em detrimento daquele, em franca oposição à teorização jurídica convencional. Essa mesma linha de raciocínio colhe, a seguir, a segunda dicotomia do direito, entre público e privado; no entanto, tal como fizera antes, Pasukanis inverte a concepção tradicional primado do público sobre o privado - ao afirmar que "o direito público só pode existir enquanto refletir a forma jurídica privada na esfera da organização política, ou então, ele deixa de ser direito. (...) O conceito de direito público somente pode ser compreendido em seu desenvolvimento: pelo qual ele é continuamente repelido pelo direito privado, na medida que tende a determinar-se como oposto daquele e pelo qual a ele regressa como seu centro de gravidade". ${ }^{282}$

Isso porque, o direito é indissociável da lógica da liberdade, da igualdade e da propriedade individual, traduzidos pelo exercício do direito subjetivo, deixando para o Estado o papel de "organizar um sistema jurídico abrangente, único, universal, suficientemente abstrato para que pudesse alcançar todas as situações". E o Estado, em observância da lógica na qual é inserido, estabelece uma organização jurídica construída na oposição entre:

\footnotetext{
${ }^{280}$ Naves, Márcio Bilharinho. Marxismo e direito...Op. Cit., p. 69/71

${ }^{281}$ Marx, Karl. Crítica ao Programa de Gotha. Disponível em: http://virtualbooks.terra.com.br/freebook/colecaoridendo/critica_ao_programa_de_gotha.htm_. Acessado em 02/07/08.

${ }^{282}$ Pasukanis, E.B. Teoria geral do direito e o marxismo...Op. Cit., p. 74, 75 e 78.
} 
de um lado, os direitos individuais; de outro, "os direitos de todos", chamando aquele de direito privado e este de direito público ${ }^{283}$.

É importante para balizar o item em tela ter em mente duas ordens de considerações: a origem do Estado capitalista e, de novo, a forma jurídica. A respeito da origem, como antes dito, depreende-se a vinculação do Estado com as relações sociais de produção e da acumulação de capital, enquanto instituição garantidora e validadora, ou melhor, "justo árbitro" da relação fundamental do capitalismo - entre proprietários de mercadorias juridicamente iguais que se apresentam no mercado, trocando força de trabalho por salário. Esta posição de terceiro desinteressado diante de uma relação particular possibilita ao Estado, simultaneamente, tomar para si o monopólio do exercício legítimo da força e apresentar-se como um ente político representante do bem comum, cindindo, desta maneira, o público e o privado ou, se quiser, Estado e sociedade, tendo por critério o tipo de interesse envolvido - o do todo ou o do individuo.

Quanto ao segundo ponto, a apresentação deste poder político - legitimo monopólio da força - se faz não mais no viés religioso e sim como forma jurídica, ou seja, a questão agora passa a traduzir o fato em direito, segundo a linguagem palatável ao capitalismo, eis aí, então, o direito público. Um obstáculo aparente que se coloca é como conciliar poder e direito, dado que operam por matizes diversas - um na base da força e o outro na da equivalência; todavia, basta voltar os olhos para a relação de troca para se verificar que a equivalência é referendada se preciso for pela força, a confirmar, em última instância, que o Estado abriga a dominação burguesa e a hierarquização social. Em outras palavras, " $a$ dominação de fato ganha um caráter pronunciado de direito publico assim que nascem a seu lado, e independentes de si, relações vinculadas ao ato de troca, relações privadas por excelência. Na medida em que a autoridade se mostra como garante destas relações, ela

\footnotetext{
${ }^{283}$ Souza Filho, Carlos Frederico Mares de. Os direitos invisíveis. In: Oliveira, Francisco de; Paoli, Maria Célia (Org). Os sentidos da democracia...Op. Cit., p.308.

Bobbio analisando o texto de Engels - As origens da família, da propriedade privada e do estado - afirma que o direito não recebeu por parte do materialismo histórico um tratamento dissociado do estado, tornando insuficiente sua teorização. Diz ele, no entanto, ser possível extrair da teoria marxiana do sistema social - base e superestrutura - a posição do direito. Se de um lado, o direito é vinculado à definição de estado como uma superestrutura política e jurídica; de outro lado, esse mesmo direito ao informar a estrutura econômica, ele se desprende do estado, na medida em que é um dos elementos a caracterizar a forma de produção em consonância com as forças produtivas. Ele conclui afirmando que essa ambigüidade do direito confirma a dicotomia entre direito privado e publico. Essas considerações de Bobbio, acerca do direito no interior da dualidade público e privado, têm por pano de fundo um tema caro ao autor - a questão do contrato social, assunto esse ausente em Pasukanis. Nem com Marx...Op. Cit., p.209/210.
} 
transforma-se numa autoridade social, em poder publico, que representa o interesse impessoal da ordem". ${ }^{284}$

A assimilação da forma jurídica ao poder público, além de outorgar ao Estado os qualificativos de imparcialidade, de neutralidade e de impessoalidade, acobertando sua razão de ser, mostra ainda que, apenas em condições específicas, vista apenas no sistema capitalista, que "a própria forma jurídica, como forma das relações de troca, já atingiu desenvolvimento suficiente para despreender-se da troca mesma, isto é, quando a forma jurídica já está apta a afirmar-se de maneira relativamente independente do conteúdo que abriga e pode então estender-se para relações alheias à circulação mercantil.", 285

Esse entrever o Estado enquanto fenômeno histórico objetivo e, por conseguinte, organizado sob a forma político-jurídica, possibilita erigi-lo à categoria de aparelho impessoal, satisfazendo, desse modo, "a necessidade objetiva do capitalismo" ${ }^{286}$. Permite-se, vislumbrar, ainda, a ordem burguesa na sua dupla dominação, expressada pela relação de dependência, seja ela: i) entre Estado e burguesia; ii) entre trabalhador e burguesia, na qual " $o$ assalariado não é coagido política e juridicamente a trabalhar para um empresário determinado, mas vende-lhe a força de trabalho mediante um livre contrato. Na medida em que a relação de exploração se realiza formalmente como relação entre dois proprietários de mercadorias independentes e iguais, (...), então o poder político de classe pode assumir a forma de um poder público". ${ }^{287}$

Ao lado dessa dominação imediata propalada nos itens anteriores; há, também, uma dominação mediata feita sob a forma de poder estatal como "poder destacado da sociedade" e controlado pela classe dominante, arcabouço esse possível, ao se apresentar delineado em um esquema formal e impessoal de exercício do poder. Tal forma de dominação não se cinge à mera explicação ideológica, pois a ideologia tem por base as relações reais, das quais ela é sua expressão mais bem acabada, uma vez que "o Estado não é apenas uma forma ideológica, mas também, e simultaneamente, uma forma de ser social. A natureza ideológica de um conceito não suprime a realidade e a materialidade das relações das quais ele é expressão", 288

\footnotetext{
${ }^{284}$ Pasukanis, E.B. Teoria geral do direito e o marxismo...Op. Cit., p.112.

${ }^{285}$ Kashiura Júnior, Celso Naoto. Critica da igualdade jurídica...Op.Cit., p. 100.

${ }^{286}$ Caldas, Camilo Onoda. Perspectivas para o direito e a cidadania. O pensamento jurídico de Cerroni e o marxismo. São Paulo: Alfa-Omega , 2006, p. 43/51 e 59.

${ }^{287}$ Pasukanis, E.B. Teoria geral do direito e o marxismo...Op. Cit., p.113 e 116.

${ }^{288}$ Pasukanis, E.B. Ibid, p. 44.
} 
O mecanismo acima tem por fundamento a cisão dos poderes político e econômico que, no limite, enseja a democracia burguesa ${ }^{289}$ enquanto "administração política" que toma para si os princípios da sociedade privada, servindo de sustentáculo à autorreprodução do capital. Nessa linha, evidencia-se a diferença entre as dinâmicas da sociedade e do Estado ${ }^{290}$; aquela pauta as relações entre proprietários de mercadorias sob as categorias de sujeito de direito, de valor e de valor de troca, no esteio de atos privados alheios a qualquer hipótese "formal" de subordinação e de arbítrio; este desobedece a tal lógica, posto que é o detentor legitimo da violência exercida no "interesse geral" (dos partícipes das relações de troca). Em outras palavras, "o poder de um homem sobre outro homem é transposto para a realidade como poder de uma maneira objetiva, imparcial." Em suma, os agentes e as relações de troca perpetradas no mercado como "fator primário", essencial não são reguladas por quaisquer das partes ali envolvidas, exige-se uma ordem estatal, por definição "secundária", como externalidade da relação privada, como garantidora e reguladora dessa última.

Nessa ótica, a coerção ${ }^{291}$ não pode situar-se no interior da relação jurídica, sob pena de ir de encontro à sua própria premissa fundamental; por isso, a coerção deve provir de uma pessoa abstrata e geral, exercida no interesse de todos os participantes das relações jurídicas, no qual o poder de um homem sobre o outro é exercido como o poder do próprio direito (norma objetiva e imparcial).

A contraposição entre público e privado permite "excluir da órbita estatal toda a representação de classe", já que, por definição, por ser público, o Estado não pode ser a "expressão de vontades e interesses privados", dando a impressão de que este é um ambiente asséptico. Ora é justamente pela liberdade e igualdade jurídicas das trocas econômicas entre os agentes que se traça o correlato entre as duas esferas, na qual a econômica vale-se da política; porquanto, o Estado é um sustentáculo do capitalismo. Isso porque dois dos instantes fundamentais - o da apropriação e o da coação - encontram-se divididos: de um lado, o Estado, relativamente autônomo, detém o monopólio da coação; de outro, o poder da classe dominante é o baluarte da apropriação organizada em torno da propriedade privada dos meios de produção, como "autoridade sem precedentes no grau de controle sobre a atividade produtiva e os seres humanos nela engajados." 292

Só para ilustrar uma das modalidades de coerção e, também, o próprio espraiar-se da forma jurídica para as relações sociais como um todo, basta voltar os olhos a Pasukanis

\footnotetext{
${ }^{289}$ Mascaro, Alysson Leandro. Para uma crítica da legalidade no Brasil contemporâneo...Op. Cit., p.30/31.

${ }^{290}$ Pasukanis, E.B. Teoria geral do direito e o marxismo...Op. Cit., p.117/119

${ }^{291}$ Naves, Márcio Bilharinho. Marxismo e direito...Op. Cit., 80/82.

${ }^{292}$ Wood, Ellen Meiksins. Democracia contra capitalismo... Op.Cit., p. 35/36.
} 
quando este teoriza o direito penal, cujo diferencial encontra-se na regulação dos limites do sistema, haja vista a necessidade de atingir, direta e imediatamente, o valor mais caro ao capitalismo - liberdade do indivíduo. Em tese, o direito penal seria o ponto de dissensão máximo do sistema na medida em que a violação do direito representasse uma ameaça ao próprio Estado, porquanto haveria o questionamento de seu fundamento. Todavia, assim não se passa, uma vez que "o transgressor sabe que violou normas válidas". ${ }^{293}$

O direito penal ${ }^{294}$ como integrante da superestrutura jurídica encarna a forma de troca de equivalentes em todas suas consequências, assumindo contornos contratuais. A realização dessas trocas no direito penal é um aspecto da realização do Estado de Direito, como forma ideal das relações entre produtores de mercadorias que atuam no mercado. Deste modo, a relação entre o infrator e o Estado se perfaz como relação jurídica com a peculiaridade de ser de ordem processual, mas que não deixa de reproduzir a lógica da equivalência, ínsita ao direito privado. A diferença encontra-se no modo pelo qual o equivalente se realiza, não mais como manifestação de vontade e sim como arbítrio de uma das partes, uma vez que a "gradação da responsabilidade" é o fundamento nuclear da determinação proporcional da pena.

Destarte, "a pena proporcional à culpa" tem a mesma significação que "a reparação proporcional ao dano", ou seja, a privação da liberdade é uma forma pela qual o direito aplica o princípio do equivalente à relação jurídica (penal). Tal correlação entre pena e reparação surge da medida de valor, que se pode mensurar em tempo o trabalho humano realizado.

Em outros termos, adota-se uma medida relacional da esfera privada (relações de produção e de circulação) para a esfera penal. “Aliás, a justiça burguesa zela cuidadosamente para que o contrato com o delinqüente seja concluído dentro de todas as regras da arte, de forma que cada um possa convencer-se de que o pagamento é igualmente determinado (publicidade do processo judicial), e de que o delinqüente pode negociar livremente sua liberdade (processo contraditório), e que pode utilizar-se de um profissional tecnicamente preparado (admissão de advogados de defesa), bem como que cada um possa controlar a aplicação da lei. Em uma palavra, as relações entre o Estado e o delinqüente situam-se nos quadros de um negócio comercial legalmente estabelecido. É nisto que constituem as garantias do processo penal." 295

\footnotetext{
${ }^{293}$ Almeida, Silvio Luiz de. O direito no jovem Lukács...Op. Cit., p. 96.

${ }^{294}$ Pasukanis, E.B. Teoria geral do direito e o marxismo...Op. Cit., p. 151, 156/161.

${ }^{295}$ Pasukanis, E.B. Ibid, p. 161.
} 
Retomando a separação entre política e economia, verifica-se aí sua consequência imediata, qual seja: a naturalização da exploração econômica bem como a limitação da política, como encarnação do interesse geral, alheia, assim, a qualquer demanda pertinente à estrutura produtiva ${ }^{296}$. Seguindo nessa lógica, o acesso ao Estado há de ser mediado pela figura do cidadão ${ }^{297}$ que é nada mais do que o próprio sujeito de direito que se presta a desvencilhar o indivíduo de sua "condição de classe". Esse tipo de ingresso na esfera pública permite que se constitua uma solução de continuidade da sociedade civil ao Estado na base do sujeito de direito, de modo que o direito e sua própria ideologia vão neutralizar a contradição da sociedade civil pela figura do "bem comum" que refuta a própria sociedade civil. Sendo assim, as figuras do homem e do cidadão são representativas, respectivamente, da sociedade civil e do Estado, cuja reconciliação é intermediada no conceito de sujeito de direito que transita em ambos os campos ${ }^{298}$.

O conceito de cidadania ${ }^{299}$ é informado pela igualdade política e jurídica na esfera pública que no fundo reproduz a mesma igualdade econômica e jurídica, com finalidade aparentemente diversa: qual seja - realização do "bem comum". Se para os liberais, a dicotomia (Estado e sociedade) significa o pressuposto para a manutenção da democracia e da liberdade; na verdade, essa dicotomia não apenas limita o conceito de democracia como também exerce uma função ideológica importante na medida que vela a realidade social na esfera estatal.

O liame que instrumentaliza essa passagem (sociedade civil para o Estado) é a eleição $^{300}$, por meio da qual se reproduz a "atomização do indivíduo", agora na esfera da política. Assim, a figura do cidadão por ser informada pela figura do sujeito de direito que simplesmente reproduz o mecanismo de circulação, só que agora não mais de mercadoria mas sim das "vontades políticas". Desse modo, percebe-se que o fundamento de um como de outro repousa no sujeito que nos remete, no limite, ao "processo do valor de troca - base real da liberdade e da igualdade".

O fenômeno da cidadania ${ }^{301}$ cuja origem remonta à Grécia tem ínsita a ideia de indivíduo como membro de uma comunidade voltada ao interesse comum, sem perder de vista que esse interesse comum é limitado, pois se está a falar de uma sociedade escravocrata. Todavia, ela não se dissocia da realidade do indivíduo membro de uma sociedade de classes,

\footnotetext{
${ }^{296}$ Caldas, Camilo Onoda. Perspectivas para o direito e a cidadania...Op. Cit., p. 96/99 e 101.

${ }^{297}$ Naves, Márcio Bilharinho. Marxismo e direito...Op. Cit., 83.

${ }^{298}$ Caldas, Camilo Onoda. Perspectivas para o direito e a cidadania...Op. Cit., 110.

${ }^{299}$ Caldas, Camilo Onoda. Ibid, p. 93/95 e 103.

${ }^{300}$ Naves, Márcio Bilharinho. Marxismo e direito...Op. Cit.,84.

${ }^{301}$ Caldas, Camilo Onoda. Perspectivas para o direito e a cidadania...Op. Cit., 106, 108 e 110
} 
pois a universalização da política atende a "necessidade objetiva do capitalismo" reconhecimento de todos os indivíduos como sujeito de direito - pressuposto de funcionamento da sociedade capitalista e do Estado de direito - que atende por uma equiparação - a da forma jurídica à forma mercantil.

Em síntese, essa aproximação permitiu ver o direito em suas categorias elementares, que transitam imediatamente pelas esferas do privado e do público, impingindo-lhes a mesma estrutura sob o manto da pretensa dicotomia entre interesses egoísticos e interesse comum. Ocorre que essa intermediação mediatamente informa os ambientes econômico e político, outorgando àquele um instrumental poderoso para o controle deste, haja vista tratar-se de um Estado de direito construído com base nas necessidades econômicas.

Este (Estado de direito) é a pedra de toque do desenvolvimento do sistema capitalista pautado no principio da legalidade que erige o individuo à categoria de sujeito, pressuposto essencial da relação jurídica contratual, relação essa que se espraia por toda a sociedade na medida que o mundo todo é “jurisdicizado". Capta-se, desse modo, a própria razão de ser do direito ${ }^{302}$ que nada mais é do que a forma da relação de troca de mercadorias só que vista pelo lado subjetivo - o lado das pessoas, dos proprietários - a forma da relação entre sujeitos abstratamente idênticos, livres um perante o outro que estabelecem um vínculo voluntário, no qual suas vontades são equivalentes, independente do conteúdo ou das disposições desta relação, ou seja, independe de qualquer exterioridade. E mais, essa matriz forma jurídica da relação entre sujeitos - pode-se espraiar para relações outras que não a econômica - intercâmbio de mercadorias - vide, por exemplo, o direito de família e, em particular, o casamento.

No entanto, essa universalização vela um privilegio de origem chancelado pela lei que se confunde com poder exercido pela classe dominante. Grupo esse que tem sua hegemonia tanto na ordem econômica como na política e que busca solapar a todo instante qualquer contestação, sob os auspícios da democracia, dos direitos humanos, mas que está a velar todo um passado, presente e futuro de arbitrariedades. E mais, essa trajetória exibe o elemento distintivo do capitalismo - "a capacidade de fazer uma distribuição universal de bens políticos sem colocar em risco suas relações constitutivas, suas coerções $e$ desiguladades", 303

\section{3) Relação entre direitos privado e social}

\footnotetext{
${ }^{302}$ Kashiura Júnior, Celso Naoto. Crítica da igualdade jurídica...Op.Cit., p. 71/73.

${ }^{303}$ Wood, Ellen Meiksins. Democracia contra capitalismo... Op.Cit., p. 23.
} 
As estruturas do capitalismo e do direito caminham lado a lado como instantes necessários e correlatos, cuja pedra de toque encontra-se na forma do direito e não no conteúdo das normas em si, forjando, assim, as categorias sujeito, relação e direito subjetivo, constituindo um sinergismo em que o primeiro dá existência ao segundo, e este escora as atividades mercantis daquele. A depender da necessidade do sistema capitalista amparado pelo todo das relações sociais e não só pelas relações econômicas, o direito dirige-se aos mais diversos fatos sociais, outorgando-lhes a linguagem do capitalismo, em razão de sua facilidade com que tem de jurisdicizar tudo, dado que a forma comporta qualquer conteúdo.

Assim, os conceitos de direito passam a informar os mais variados âmbitos sociais, desde seu coração - esferas da produção e da circulação - passando pelo Estado e chegando as relações menores, tais como as hipóteses previstas no art. 275 do CPC, extensíveis ao Juizado Civil, todas elas observando uma lógica única, pois o direito é erigido em cima da lógica mercantil e dela é inseparável. "Assim sendo, não é pela quantidade nem pelo assunto que se há de identificar o direito moderno, e sim pela qualidade, correlata da forma mercantil que o é. A depender das relações sociais de exploração, de certas estruturas, necessidades, interesses e vontades da sociedade, tudo poderá ser chamado por jurídico. Pode-se dizer, então, que é vasto e largo o limite de incidência das técnicas jurídicas modernas nos fenômenos sociais humanos. E é bem nesse limite que se situam as fronteiras quantitativas da questão jurídica. Quantos assuntos são jurídicos e sobre quantas coisas se esparrama o direito? A princípio tudo." 304

Estas considerações têm sua razão de ser para afastar uma concepção arraigada em um pensamento bondoso em ver nos direitos sociais e aqui está a se falar, basicamente, do direito do trabalho, um direito que observa uma lógica diversa da mercantil ou, se quiser, a humanização do capital, como se fosse solução para a reificação do homem, se é que isso é possível dentro do sistema capitalista. É indiscutível que o direito do trabalho tem o mérito de ir além dos direitos civil e do consumidor no que tange à ideia de igualdade, mas daí a concebê-lo como contrário ao capitalismo vai um longo percurso.

Este é um dos pontos para reflexão do item em tela, se não há questionamentos quanto ao fato dos direitos civis e políticos, analisados por Marx, na questão judaica, serem direitos eminentemente burgueses do homem egoísta, traçando a separação entre sujeito econômico e sujeito político, referendando a cisão entre Estado e sociedade, a fim de estabelecer o apogeu do indivíduo frente ao coletivo, ou seja, de dissociar o homem individual

\footnotetext{
${ }^{304}$ Mascaro, Alysson Leandro. Introdução ao estudo do direito...Op. Cit., p.21.
} 
da classe a qual pertence que, ao fim e cabo de tudo, funciona como álibi para a exploração de classe, o problema ganha outros contornos com os direitos sociais.

De plano, destaca-se o rompimento dos direitos sociais com a igualdade formal absoluta dos códigos civis do Estado liberal migrando para a igualdade aristotélica em moldes semelhantes àquela do direito do consumidor. Aqui há de se atentar para dois detalhes: um de cunho cronológico na esteira da evolução do sistema capitalista, na passagem do fordismo ao toyotismo, onde o direito do trabalho antecede ao do consumidor. Aquele situado no final do século XIX, início do século XX; este, no final do século XX e inicio do século XXI. Outro detalhe é com relação aos limites, se para os direitos do consumidor, situado na esfera da circulação, o reconhecimento da desigualdade fomenta direta e imediatamente o fluxo das trocas, na medida que apenas referenda em outro patamar a forma jurídica contratual, forma essa primordial à circulação, com custos mínimos ao capital - basta rearranjar a igualdade formal pela proteção jurídica à parte mais fraca - porquanto, mantém intocada a joia da coroa - mais valia. Percurso semelhante, do reconhecimento da desigualdade que, em última instância, põe a salvo a igualdade jurídica formal, se dá no âmbito do direito do trabalho, só que operando com mais qualidade e profundidade. Aliás, aqui o processo é mais tenso e de limites mais estreitos, porquanto muito próximo do coração do sistema, esfera da produção. A igualação promovida, nesta seara, é superior à anterior, dirige-se à igualdade material, avança e encontra limites nos domínios da mais valia, de modo seus contornos hão de ser, necessariamente, muito mais parciais, sob pena de avançar, em demasia, sobre a lógica contratual mercantil da troca entre força de trabalho por salário e, assim, ao invés de referendá-la, pô-la em cheque. Não se está aqui a dizer que é possível destruir o sistema capitalista pela via dos direitos sociais mas sim alertar para o horizonte de que os direitos sociais que, pela sua singularidade, promoção de uma relativa igualdade material, incomodam o capital, haja vista terem eles sido eleitos como o causador e sua flexibilização ou, até mesmo, sua retirada como solução para a crise do Estado Social.

Se o conteúdo das normas de direito do trabalho, engendrado na luta de classes resultando em conquistas de direitos (férias, $13^{\circ}$ salário, pagamento diferenciado de horas extras, dentre outros) e em proteção contra os excessos dos capitalistas (higiene, segurança, trabalho infantil e da mulher, jornada, etc...). Em suma, todo o rol do artigo 7 da CRFB/88, pode ir de encontro aos anseios dos capitalistas em particular, pois operam uma nova divisão na mais valia. Esse mesmo direito do trabalho, em última instância, age em prol do funcionamento do sistema capitalista como um todo, permitindo sua reprodução e mantendo possível a exploração só que agora em outro patamar. A razão para tal constatação reflete a 
lógica na qual ele é forjado, ou seja, o respeito incondicional à forma jurídica do sujeito de direito, da relação e do direito subjetivo e que, ao fim e ao cabo de tudo, alimenta o individualismo, configurando, no limite, aquilo que Edelman chamou de processo de integração da classe trabalhadora ao capital - “du poison dans ses cadeaux",305. Este parágrafo pela sua relevância merece maior detalhamento sob três perspectivas: natureza do direito do trabalho e de suas derivações - os direitos individuais e coletivos.

Quanto ao direito individual do trabalho e, mais precisamente, quanto ao contrato de trabalho maiores esclarecimentos do que aqueles já prestados não são necessários, de modo que esse ponto pode ser arrematado com as considerações de Edelman no tocante ao poder jurídico do capital ${ }^{306}$. Afirma ele que esse poder assume uma "dupla forma": do ponto de vista do trabalhador, o capital toma a forma de contrato de trabalho como "técnica de venda do trabalho" que tem como contrapartida o direito a um salário. E, do ponto de vista do empregador, o capital assume a forma de direito de propriedade, propriedade essa - dos meios de produção - que compra a força de trabalho sobre a forma de salário e a incorpora juridicamente a sua propriedade. Esta dupla forma do capital, no entanto, espelha sua unidade, qual seja: o capital sob a forma do direito de propriedade.

Quanto aos domínios do direito coletivo, os assombros ganham em dimensão quando se comparados àqueles do direito individual, pois como pensar, por exemplo, dois importantes direitos coletivos como são a greve e os sindicatos, espaços, por excelência, dos trabalhadores, como direitos burgueses, ou seja, como direitos que não negam o direito de propriedade e, no limite, reproduzem-na.

De pronto, haveria duas ordens de grandeza a serem superadas pelo direito: a primeira delas, refere-se ao direito de greve como ato coletivo, direito esse que não se encaixa nos domínios do direito do homem - direitos individuais e inatos à pessoa humana; a segunda, os direitos individuais encontram seus limites naturais no direito do outro, e a greve pela sua própria natureza não tem essa conotação. Ela justamente objetiva "prejudica o outro", no caso o empregador. Como equacionar, então, estas duas questões, a resposta para ambas é una e passa pela sua submissão ao regime da legalidade ${ }^{307}$, na qual é possível não só atribuir a titularidade a um sujeito, no caso a uma coletividade e não aos indivíduos em particular como também constituir a greve como um direito.

\footnotetext{
${ }^{305}$ Edelman, Bernard. La légalization de la classe ouvrière. L`entreprise. Paris: Christian Bourgois Editeur, 1978, p. 11.

${ }^{306}$ Edelman, Bernard. Ibid, p.28/29.

${ }^{307}$ Edelman, Bernard. Ibid, p.70.
} 
Nesse sentido, Edelman monta todo seu raciocínio e argumentação em torno da idéia da circunscrição do fato ao direito, ou seja, "na outorga da linguagem da legalidade burguesa à classe operária”. Esse tema não é novo para a presente dissertação, ele fora aventado em outro contexto, no capítulo anterior, quanto às considerações de Bercovicci em torno da relação entre poder constituinte e poder construído, no qual se verifica claramente a função do direito como limite à política, isso porque para o direito, o conflito há de residir em seu interior, ou melhor, na oposição entre dois direitos, cabendo ao juiz escolher um deles pelas técnicas disponíveis, hoje, muito em voga a ponderação e a razoabilidade. E mais, o direito ao se deparar com um "fato não jurídico", ele invariavelmente procura reafirmar-se, porquanto não reconhece o fato, dado que trabalha na dicotomia ser e dever ser.

Nessa esteira de pensamento, a greve deixa de ser um fato para tornar-se uma categoria jurídica - direito de greve - pagando o preço de sua existência dentro do direito, qual seja: a submissão ao poder jurídico do capital quer seja no âmbito da sociedade civil ou do Estado. Fenômeno semelhante ocorre com os sindicatos, pois que ao se deparar com o fato em si, no caso, as "organizações de massa", a burguesia se vale de seu arsenal para transformá-los em "aparelho ideológico do Estado", seja pela outorga de um poder burguês e, portanto, de direito, trazendo os sindicatos para o interior da legalidade ou, ainda, um poder de fato na medida que, por presunção, representam as massas. ${ }^{308}$

No que tange à greve, Edelman faz um inventário da sua "contratualização"309, desde sua circunscrição aos limites do direito penal, passando pelo seu tratamento no direito civil como greve-rompimento do contrato de trabalho, liberando ambas as partes (patrão e empregado) para celebrarem novos contratos, ou seja, permite a substituição imediata dos grevistas por outros trabalhadores e possibilitando, ainda, a responsabilização pelos prejuízos decorrentes da greve.

Depois a chegada da greve à seara do direito do trabalho, passa a ter um tratamento diverso do anterior, tem-se a greve-suspensão do contrato de trabalho, o que permite sua modulação dentro dos limites legais: de um lado, autoriza a reivindicação e a defesa de

\footnotetext{
308 "Car, on le verra, la greve est devenu un droit à la seule condition de se soumettre au povoir juridique du Capital, dans la société civile comme dans l'Etat. Elle est devenue um droit à la condition d`être mesurée à l'aune du droit dês obligations (contrat de travail) et du droit de propriété (propriété dês moyens de production). (...) Mais em réglementant la grève, la bourgeoisie n'en est pas quitte pour autant: il lui reste à circonvenir les organisations de masse, les syndicats, et là nous assistons à une stratégie très fine. Affrontée au fait syndical, la bourgeoisie utilize toutes les armes pour le transformer en appareil ideólogique d’Etat. Em lui octroyant um pouvoir qui reproduise son propre pouvoir; um pouvoir de droit, bien sûr, mais em tant seulement que les syndicats existente dans la légalité; mais um pouvoir de fait surtout,em tant, que cês mêmes syndicats seront présumés représenter les masses." Edelman, Bernard. La légalization de la classe ouvrière...Op. Cit.,p.17/18.

${ }^{309}$ Edelman, Bernard. Ibid, p.31/46.
} 
direitos e interesses profissionais, ou seja, exigências em torno do conteúdo das cláusulas contratuais; de outro lado, limita-a aos domínios da relação Capital-Trabalho, mais especificamente da sua reprodução, caso ultrapasse essa linha, pode vir a ser considerada ilícita pelos tribunais. Essa circunscrição do fato (greve) ao direito (direito de greve) é feita em três linhas, ${ }^{310}$ todas elas na base comum da "representação sindical" de onde se logra: i) transformar os grevistas em um "grupo pacífico" e de considerar os "líderes grevistas", como dirigentes sindicais, ii) tratar a greve uma "modalidade de discussão" e iii) ver no sindicato um "aparelho de discussão".

A concepção da greve-suspensão do contrato de trabalho traz um problema teórico aos juristas, pois já não mais se pode afirmar que de um lado a greve suspende o contrato e de outro subsiste um liame contratual entre trabalhador e empregador e aí vem a pergunta como superar o impasse? A resposta encontrada pelos juristas apela para o reconhecimento de uma ligação de fato e não de direito que une os empregados à empresa, de modo que esse liame não pode ser outra coisa, senão um vínculo econômico, que nada mais é do que a relação capital e trabalho e que, portanto, nada tem de jurídico. No entanto, essa relação é, também, outra coisa - ideologia jurídica, mais precisamente a ideologia jurídica do trabalho reproduzida nessas palavras: "dentro dos domínios sociais mais do que qualquer um outro, ele se importa de evitar a discordância entre direito e fato, pois se as leis não estão adaptadas à realidade, as ligações do trabalho se desenvolvem fora do direito sob a dependência do jogo de forças presentes, há de se esforçar para aproximar o direito social da realidade dos fatos,contribuindo assim para o progresso desse direito"311.

Por último, nessa trajetória dentro do plano contratual, a greve é erigida ao patamar constitucional, alçando uma proteção maior a depender do tipo de constituição a que se está considerando - rígida, flexível, semirrígida - quando se comparada à legislação ordinária, mas em que nada altera sua estrutura.

De fato, o que é relevante para os domínios desta dissertação, com relação ao processo de contratualização da greve é poder mostrá-lo como um exemplo vivo da cunha engendrada pelo capitalismo entre política e economia, pois que a limitação da greve a legalidade burguesa, ratifica o trabalho como atividade eminentemente privada e retira da

\footnotetext{
${ }^{310}$ Edelman, Bernard. La légalization de la classe ouvrière...Op. Cit.,p.144, 158, 159, 162, 168 e 169.

311 "Dans Le domaine social plus qu'en tout autre, Il importe d'eviter les discordances entre le droit et le fait, car si les cadres juridiques ne sont pas adaptés à la realité, síls n'évoluent pas avec elle, les rapports du travail se developperont en-dehors du droit, sous la seule dependence du jeu des forces en presence. C'est pourquoi nous croyons à l'utilité, à la nécessité de l'effort que nous vous demandons aujourd'hui, car em éliminant du régime du travail dês éléments fictifs, il rapprochera le droit social de la réalité dês faits et contribuera par là même au progrés de ce droit”. Edelman, Bernard. Ibid, p.43.
} 
greve qualquer conotação política. E mais, esta concepção, arraigada na separação Estado e sociedade civil, põe a questão da definição jurídica da política ${ }^{312}$, nos seguintes termos: a política para o direito é o funcionamento das instituições constitucionais que excluem a classe operária enquanto classe e transforma-a em uma soma de cidadãos. A razão de ser desta separação entre as esferas profissional e política remonta a interdição legal de fazer dos trabalhadores de ver a luta econômica como uma luta política.

Após ver a greve como um instituto jurídico, pode-se passar para o campo sindical, sem esquecer que, no capitulo anterior, Milliband discorreu sobre o Estado na Sociedade Capitalista de onde se depreende não só a invasão como também a incorporação do ethos burguês à classe trabalhadora, faltando, agora, a burguesia apropriar-se da classe trabalhadora enquanto classe, ou seja, de sua organização - dos sindicatos.

O processo segue a lógica acima, ou seja, outorgar as massas uma fala e uma estrutura dentro da lei, investindo o sindicato de um poder de representação da classe operária, restringindo-o dentro dessa legalidade e, no limite, tornando-o mais um dos "aparelhos ideológicos do Estado". Esta dinâmica tem algumas peculiaridades ${ }^{313}$, pois diferentemente de abstrações como povo e nação ou, então, de um "corpo" como é o eleitoral, a classe operária, além de ser bem concreta, sua existência é "extralegal" no sentido de que não pertence a ninguém senão a ela mesma; então, vem a pergunta como torná-la palatável ao direito?

Há alguns obstáculos a serem transpostos. O primeiro deles, é quanto à representação que, necessariamente, há de passar pelo sindicato, mas que não se pode conceber a representação sindical da totalidade dos grevistas sob pena de afrontar a liberdade individual do trabalho, estabelecendo aí um instante delicado na medida que o coletivo é posto questionando o indivíduo. Qual é a solução, então, reafirmar o individualismo, seja pelo princípio da liberdade sindical (poder ou não se sindicalizar como também poder se retirar a qualquer tempo) ou pelo direito individual a dissidência, como entrave à liberdade de ação do grupo que finda por fomentar sua própria divisão na medida que a maioria não pode constranger a minoria a aderir à greve, por exemplo. No entanto, essa resposta eiva o

\footnotetext{
312 "On a bien compris: la politique, pour le droit, c'est le fonctionnement des institutions constitutionnelles, qui exclut la classe ouvrière en tant que classe, et la transforme en une somme de citoyens. Et on a bien compris ce que cachait la distinction professionnel/politique: l'interdiction légale faite aux travailleurs d'envisage la lute économique comme une lutte politique". Edelman, Bernard. La légalization de la classe ouvrière...Op. Cit.,p. 68.

${ }^{313}$ Edelman, Bernard. Ibid, p.142.
} 
sindicato da possibilidade de ser o representante jurídico da greve e obriga ao direito, no caso aos tribunais, a reconhecerem um poder de fato - "liberdade das massas". 314

Como é possível para o direito reconhecer algo fora de seus domínios, há de se retornar à ideia do contrato social - dois mundos: o da natureza e o do direito - mas como aplicar essa teoria para além de seus domínios - formação do Estado moderno? Estas indagações são tratadas pelo direito do único modo possível, qual seja: pelo corte ou, se quiser, pela sua ficção ou presunção, de modo que se a greve for tratada como uma suspensão do contrato de trabalho e, por conseguinte, como uma modalidade de discussão deste mesmo contrato, os grevistas em relação à empresa permanecem na qualidade de empregados, com a peculiaridade de não mais estarem submetidos ao poder disciplinar do patrão e sim a autoridade de seus representantes. Ou seja, o trabalhador, quer seja na qualidade de empregado ou de grevista, está sempre subordinado a uma organização, seja ela a empresa ou o sindicato. ${ }^{315}$ E mais esta concepção de greve consertação tem reflexos sobre o sindicato que, com o passar do tempo, torna-se um "colaborador do capital".

Daí se depreende a natureza do poder sindical ${ }^{316}$ que é um "poder de discussão", no qual prevalece o horizonte da negociação sem a ideia de confronto/antagonismo capital e trabalho com respeito à propriedade, a liberdade individual do trabalho, trazendo a classe operária para a linguagem do direito, ou melhor, de sua ordem e passividade. Pois, ao final das contas, a burguesia imprime ao sindicato a sua marca e o faz funcionar sobre seu modelo de gestão e de burocracia, na base da representação, da hierarquia e da disciplina, em suma, "em colaboração".

O testemunho de José Ricardo Ramalho ${ }^{317}$ sobre o caso brasileiro não se afasta dessa linha com uma peculiaridade de peso, o advento do neoliberalismo na América Latina. Ele não só traça um comparativo entre a atuação sindical, nos anos de 1970 e de 1980, com relação aos anos de 1990, como também entre CUT e Força Sindical ou mesmo no interior da própria CUT quanto ao tema da concertação. O debate, envolto pela reestruturação da organização produtiva, colhe em cheio a organização sindical, pois como conciliar a prática

\footnotetext{
${ }^{314}$ Edelman, Bernard. La légalization de la classe ouvrière...Op. Cit.,p.150/151.

315 "Reste alors la question de leur representation. (...) Em temps normal, le personnel est soumis à l'autorité du chef d'entreprise;em temps de grève, il est soumis à l'autorité de sés propres représentants. (...) On voit tout l'avantage d'une telle analyse. D'une part, la greve est envisagée comme une simple modalité de discussion, d'autre part les grévistes sont assimilés tout naturellment à une communauté de travail ou d'entreprise, enfin, et tout aussi naturellement, ils se trouvent de ce fait représentés par les délégués. Ainsi, au double visage du travailleur - salarié ou gréviste - correspond une double organization - celle de l'entreprise et celle des syndicats, et une subordination alternative". Edelman, Bernard. Ibid, p.166/167.

${ }^{316}$ Edelman, Bernard. Ibid, p.182/183.

${ }^{317}$ Movimento sindical e política neoliberal. In: Sader, Emir; Gentili, Pablo (org.). Pós-Neoliberalismo...Op. Cit., p. $125 / 133$.
} 
da parceria capital e trabalho com o ideário socialista e, mais, nesse ambiente de regresso, no qual a própria organização sindical luta pela sua sobrevivência, a política (defensiva) de participação aos moldes da social democracia não é simultaneamente uma política ofensiva, caso se considerar a especificidade do caso brasileiro que apenas formalmente atingiu a social democracia em 1988.

E aí vem a pergunta: "Como é possível, hoje, articular valores inspirados num projeto que olha para a sociedade para além do capital, mas que tem que dar respostas imediatas para a barbárie que assola o cotidiano do ser que vive do trabalho? [...] Como superar um caminho meramente doutrinário e buscar a difícil e imprescindível articulação entre os interesses imediatos e uma ação estratégica, de longo prazo, de clara conformação anticapitalista?" 318

Um indicativo de resposta é aquele bem sintetizada por Grana da Federação dos Metalúrgicos de São Paulo que dá pistas da dimensão dos direitos sociais: "nós não somos daqueles que acreditam que quanto pior melhor. Que com a gente empobrecendo, o povo sendo cada vez mais massacrado, nós vamos conseguir atingir um grau de socialismo. Achamos que quanto mais informações a classe trabalhadora, o operariado, os setores progressistas vão obtendo, mais influência social se consegue, podendo assim intervir na decisão e mudança social. Isso porque o sujeito consciente das condições que tem para intervir na sociedade, ele reivindica, vai buscar mudanças". 319

Quanto ao conteúdo da fala aqui reproduzida, no limite, ela pode ser estendida a discussão a respeito da possibilidade de um socialismo democrático, tema de per si complexo e que demandaria uma investigação própria, que não é objeto desta dissertação que se limita aos domínios dos direitos sociais em sua amplitude máxima dentro do capitalismo, qual seja: Welfare State. Nesse momento, sem querer abrir frente sobre o tema do socialismo democrático, é preciso aproveitar a oportunidade para ratificar, uma vez mais os limites do direito. Tal empreitada há de ser feita relembrando o alerta de Bilharinho ${ }^{320}$ sobre a denominada "A ilusão da jurisprudência" - redução da luta social a querela jurídica: "a democracia como forma e a distribuição da riqueza como seu substrato material" - que finda por equiparar o socialismo à Declaração Universal dos Direitos pela categoria da cidadania. Isso porque traçar um projeto de emancipação da humanidade tendo em sua base esperanças

\footnotetext{
${ }^{318}$ Ramalho, José Ricardo. Movimento sindical e política neoliberal. In: Sader, Emir; Gentili, Pablo (org.). PósNeoliberalismo...Op. Cit.,131.

${ }^{319}$ Ramalho, José Ricardo. Ibid, p.131.

${ }^{320}$ Naves, Márcio Bilharinho. A “ilusão da jurisprudência”. Disponível em: http://www.pucsp.br/neils/downloads/v7_artigo_marcio_naves.pdf . Acessado em 11/08/09.
} 
iluministas no direito, esquecendo-se de sua origem, acaba por relegar a própria obra de Marx que em inúmeras passagens apontou os "estreitos limites do direito burguês", limites esses já experimentados por parte da humanidade - Welfare State.

Feita esta sumária digressão em um tema externo à presente dissertação, o intuito do presente item é mostrar com base em duas ordens de considerações, na esteira do pensamento de Edelman, como o conflito capital e trabalho é colhido pelo direito propriamente dito, bem como pelos aparelhos ideológicos do Estado (escola, imprensa, sindicato etc...) de modo a fazer com que, na base dessa dupla consideração, possa-se vislumbrar a luta do movimento operário, resultando em conquistas que se faz circunscrita a legalidade burguesa e que, no limite, finda por reproduzir o próprio ethos burguês, na medida que sua historia é um ajuste permanente da relação capital e trabalho dentro da estrutura da lei como uma ligação jurídica entre sujeitos.

Mostrada esta perspectiva, pode-se claramente fazer a distinção entre autonomia e natureza do direito do trabalho ${ }^{321}$. A autonomia é o reconhecimento de sua especificidade e, por conseguinte, de seus resultados traduzidos em uma relativa igualdade material, frutos esses não vistos em qualquer outro ramo do direito. Mas, daí a situá-lo em oposição ao direito burguês e, especificamente, ao direito de propriedade, é negar sua própria natureza. Primeiro, porque se o direito do trabalho é uma conquista, reflexo de um poder, da classe operária dentro do quadro da legalidade burguesa, como pode esse poder ser de outra natureza que não o burguês, como pode ser ele um novo direito. Isso não contraria uma das máximas do nosso ordenamento da qual ninguém pode transferir mais direitos do que tem?

Depois, não se pode esquecer a dimensão do todo, do orgânico do direito, pois as movimentações do coletivo, da massa são invariavelmente circunscritas diante dos grandes princípios do direito - liberdade, igualdade, do homem em abstrato, ou seja, em última instância, a propriedade privada. Esses sim são as verdadeiras áreas de conforto do direito, pois ali toda e qualquer diferença de fato é reduzida a uma igualdade jurídica. É pelo entendimento do direito, como um todo uno e indivisível que se compreende como a divisão jurídica do trabalho reproduz a sua maneira a divisão do trabalho, no qual o direito do trabalho é a expressão jurídica do segredo do capital - extração da mais valia pela venda da mercadoria.

\footnotetext{
${ }^{321}$ Edelman, Bernard. La légalization de la classe ouvrière...Op. Cit.,p.12/13.
} 
Por fim, o que se objetiva depreender deste capítulo e, ao mesmo tempo, servir de base/limites para as reflexões do capitulo seguinte é de que o direito ${ }^{322}$ organiza o conjunto da sociedade na esfera privada, colocando o homem no lugar da classe, o trabalho no lugar da força de trabalho, o empregado no lugar da mais valia, o exercício da liberdade instrumentalizada pelo contrato de trabalho no lugar da exploração do homem pelo homem e mais esse mesmo direito é ainda capaz de organizar essa mesma sociedade na esfera pública colocando a vontade geral no lugar do Estado de classe.

Essa leitura peculiar do direito - indissociado do capitalismo - torna palatável a compreensão do porquê de outros direitos sociais, tais como: a previdência, a assistência, a saúde e a educação só para citar os mais comuns, terem sua tradução e expressão na base do indivíduo. No entanto, essa leitura não é elucidativa do caso brasileiro, onde há um déficit de concretização desses mesmos direitos, e isso sem olvidar que se está falando de sua versão mais basilar, qual seja: do indivíduo, tema nuclear a partir das declarações de direito dos séculos XVIII em diante. O nó górdio não foi desvendado, esse capítulo apenas procurou afastar do tratamento da questão do plano eminentemente jurídico, convergindo, em parte, para as considerações sobre o Estado e, mais especificamente, da política, arroladas no capitulo I, faltando agora unir esses dois nortes - política e os limites do direito - em torno do tema do subdesenvolvimento e aí sim trazer mais luzes à questão dos direitos sociais dentro de seu habitat - mundo capitalista.

\footnotetext{
322 "Nous n'avons cessé de le rencontrer sur notre rute: seul l'ordre juridique met, concrètment, l'homme à la place des classe, le travail à la place de la force de travail, le salarie à la place de la plus-value; seul l'ordre juridique envisage l'exploitation de l'homme par l'homme comme le produit d'um libre contrat, comme l'exercice de la liberté; et lui seul, encore, envisage l'Etat de classe comme l'expression de la volonté générale". Edelman, Bernard. La légalization de la classe ouvrière...Op. Cit.,p.108.
} 


\section{CAPÍTULO III) Direitos Sociais - Origens, limites e desconstrução}

O norte do capítulo pauta-se no até aqui desenvolvido em que se verificou a trajetória dos direitos, desde os civis e políticos, passando pelos direitos sociais até seu refluxo num ambiente de alterações de modelo de Estado. Restou claro que a consolidação dos primeiros tem, por consequência, a democracia formal que carrega o germe da formulação dos direitos sociais que galgou patamares constitucionais e, até mesmo, internacionais, mas cuja implementação não encontrou ressonância nesta mesma democracia. O percurso todo é pautado pela dialeticidade das relações sociais da qual emanam as alternativas do possível em um tênue e complexo equilíbrio de compromissos e interesses, que redundam em estruturas, instituições e políticas que marcam a vida social, bem como suas potenciais modificações.

No que tange aos limites do direito, Pasukanis foi preciso, ao estabelecer a conexão entre economia e direito (privado) pela relação jurídica entre sujeitos informada pelo principio da equivalência. A mesma lógica foi transmitida ao Estado e, em particular, ao direito público na medida que a pretensa separação entre Estado e sociedade é relativa, de modo que a própria intervenção do Estado na economia, visível no século $\mathrm{XX}$, desenvolveu-se sob o ferramental jurídico disponível a fim de instrumentalizar sua atuação.

Márcio Bilharinho deu um passo à frente ao apreender que a equação de ambos os direitos contaminou os direitos políticos e, em especial, a democracia política trabalhada em função da individualização. E, mais ainda, Correia $^{323}$ percebeu que os direitos sociais transitam pelas duas esferas - pública e privada - originando-se na primeira e fruindo-se na segunda, de modo que a lógica da relação jurídica assentada no principio da equivalência é ratificada mesmo em uma perspectiva de proteção social, local de atuação por excelência dessa modalidade de direito. Dentro ainda dos direitos sociais, Edelman fez considerações pertinentes ao direito do trabalho, alertando para o fato de que esse direito, em que pese represente em grande parte o esforço empreendido pela classe trabalhadora, ele, na verdade, não foge da perspectiva burguesa, na medida que é o responsável por amalgamar dentro de

\footnotetext{
323 Discorrendo sobre a funcionalidade dos direitos sociais: “Assim, estes não se caracterizam, no nosso entender, como uma categoria distinta dos direitos público e privado, mas permeiam ambos nos instantes em que ocorressem traços comuns distintivos e que necessitassem de ser tratados sob a perspectiva da proteção social maximizada. (...) Portanto, os princípios e postulados dos direitos sociais podem nortear tanto relações de direito privado, quanto de direito publico, havendo apenas que se dimensionar, no âmbito destes, quando aquele se encontre presente”. Maior, Jorge Luiz Souto; Correia, Marcus Orione Gonçalves. O que é direito social? In: Correia, Marcus Orione Gonçalves (org). Curso de direito do trabalho. Vol. 1. São Paulo: LTr, 2007, p. 24.
} 
uma estrutura jurídica a relação capital e trabalho, fazendo do direito do trabalho a expressão jurídica do segredo do capital.

Os capítulos anteriores são pressupostos para entender não apenas o porquê dos direitos sociais enquanto inflexão do projeto burguês, mas também para indicar o porquê da não ruptura dos direitos sociais com o ideário liberal. Para tanto, basta ver sua captura pela lógica do capital no contexto da globalização. Apreensão essa que se produziu de plano pelo direito processual, seguido de sua não materialização, seja pela via da norma programática ou pela interpretação judicial e que teve a pedra de toque nas emendas constitucionais que trouxeram mudanças significativas nas ordens social e econômico-financeira de onde se denota a simbiose entre público e privado, de acordo com as necessidades do último.

Após uma aproximação político-econômica da sociedade corroborada com o estudo dos conceitos fundamentais do direito é que se pode vislumbrar o estágio atual de nossa Constituição quanto à perspectiva dos direitos sociais. Aqui, o trabalho encontra-se apto a dirigir-se para analisar a estrutura da seguridade social e os desafios de seu funcionamento na ótica da efetividade e eficácia em um ambiente público vazado pelo privado e pela presença de uma incipiente democracia participativa.

Dada a amplitude do que se entende, classifica ou imputa como direitos sociais, conforme abaixo será conceituado, é impossível para os limites deste trabalho, analisá-los em sua totalidade. Sendo assim, incursões dar-se-ão no horizonte de uma tentativa de teoria geral para os direitos sociais, tendo em vista a realidade que o cerca, qual seja: a expansão dos espaços do capital para toda a vida social de onde se ter como exemplos imediatos, a previdência e a saúde privadas e, como exemplo mediato, os programas assistenciais como é o caso do programa bolsa família.

Quanto à cooptação da previdência e da saúde pelo privado aqui não requer maiores esclarecimentos, porquanto o próprio texto constitucional denuncia a inter-relação do público com o privado. Para tanto, basta ver a permissividade ao privado do texto constitucional e suas receptivas legislações que acabam situando a relação entre público e privado da seguinte forma: aquele fica adstrito a estatuir a regulação do sistema, enquanto este faz, às vezes, do Estado na execução de alguns serviços propriamente ditos. Maiores surpresas advêm da assistência - local, por excelência, da institucionalização e da jurisdicialização do princípio da solidariedade em detrimento do antigo dever moral de auxílio - que passa com o programa bolsa escola, seguido pelo sucedâneo bolsa família ${ }^{324}$, na esteira da política neoliberal de

\footnotetext{
${ }^{324}$ Por bolsa família entende-se "um programa de transferência de renda com condicionalidades, que beneficia famílias em situação de pobreza (com renda mensal por pessoa de $\mathrm{R} \$ 70,00$ à $\mathrm{R} \$ 140,00$ ) e extrema pobreza
} 
tratamento à pobreza implementada ao sabor dos ditames do Banco Mundial e dos organismos internacionais congêneres, a receber uma atenção maior dos governos locais.

Este é o basicamente o tom das políticas de Estado no curso da passagem do Estado Social para o Estado neoliberal, movimento esse caracterizado pela retração das políticas de Welfare State e pelo fomento das políticas assistenciais.

\section{1) Primeira aproximação - enfoque político}

Primeiro, há de se retomar alguns pontos a fim de adentrar na especificidade dos direitos sociais. "Aparentemente", a legitimação do Estado migrou da repressão ao consenso, na medida que consagra a figura do individuo como sujeito de direito (público) e avoca para si a unidade social pela via da ocultação das diferenças, porquanto "o capitalismo manda a política e o direito falarem a linguagem da igualdade" ${ }^{325}$.

Essa marcha diz respeito à própria natureza do Estado enquanto representante do bem comum e do interesse geral que se constrói pela cisão entre os poderes político e

(com renda mensal por pessoa de até $\mathrm{R} \$ 70,00$ ), de acordo com a lei 10.836, de 09 de janeiro de 2004 e o Decreto $\mathrm{n}^{\circ} 5.209$, de 17 de setembro de 2004". O programa tem por meta num primeiro instante aliviar e, em seguida, erradicar a extrema pobreza, possibilitando o desenvolvimento das famílias mais vulneráveis à fome a fim de que conquistem patamares mínimos de cidadania. Com vistas a atingir seus propósitos, o programa tem cunho seletivo e focalizado, desenvolvido a partir da conjugação dos critérios renda e exigência de algumas condicionalidades na área da saúde e da educação. Quanto ao primeiro critério - renda - ela é dividida em 02 grupos: i) famílias com renda mensal de até $\mathrm{R} \$ 70,00$ (setenta reais) por pessoa independente da idade dos membros da família; ii) famílias com renda mensal entre $\mathrm{R} \$ 70,01$ (setenta reais e um centavo) e $\mathrm{R} \$ 140,00$ (cento e quarenta reais) desde que tenham filhos em idade entre 0 e 17 anos. Por renda per capta da família entende-se: o resultado da divisão do total de recursos angariado num mês por todos os integrantes de uma família (por exemplo, salários e aposentadorias) pelo $\mathrm{n}^{\circ}$ de pessoas que habitam uma determinada residência. Quanto ao segundo critério - condicionalidades - elas são relacionadas à freqüência escolar das crianças e adolescente e mais o cumprimento de cuidados essenciais na área da saúde, tais como acompanhar o calendário de vacinação para crianças entre 0 e 6 anos, bem com seguir a agenda pré e pós natal para gestantes e mães em fase de amamentação. Com relação aos valores pagos pelo programa bolsa família, eles variam de $\mathrm{R} \$ 22,00$ (vinte e dois reais) a $\mathrm{R} \$ 220,00$ (duzentos e vinte reais) de acordo com a renda mensal por pessoa da família e com o número de crianças e adolescentes de até 15 anos e de jovens de 16 e 17 anos. Há três tipos de benefícios: i) básico, no valor de $\mathrm{R} \$ 68,00$ (sessenta e oito reais) destinado a famílias extremamente pobres (aquelas com renda mensal de até $R \$ 70,00$ - setenta reais - por pessoa); ii) variável de $R$ \$ 22,00 (vinte e dois reais) até $R \$$ 66,00 (sessenta e seis reais), ou seja, no mínimo de 1 (um) e no máximo de 3 (três) benefícios pagos a famílias pobres (aquelas com renda mensal de até $\mathrm{R} \$ 140,00$ - cento e quarenta reais - por pessoa), desde que tenham crianças e adolescentes de até 15 anos; iii) variável de $\mathrm{R} \$ 33,00$ (trinta e três reais) até $\mathrm{R} \$ 66,00$ (sessenta e seis reais), ou seja, no mínimo de 1 (um) e no máximo de 2 (dois) benefícios pagos a família, desde que tenha adolescente de 16 e 17 anos freqüentado a escola. Informações retiradas do sítio do Ministério do Desenvolvimento Social e Combate à fome. Disponível em: http://www.mds.gov.br/bolsafamilia. Acessado em 03/12/09.

${ }^{325}$ Mascaro, Alysson Leandro. Para uma crítica da legalidade no Brasil contemporâneo...Op. Cit., p. 16. 
econômico, o que o capacita a atuar a posteriori sobre a questão social, seja na modalidade repressão ou institucionalização do conflito pela via das políticas públicas ${ }^{326}$.

Essa ideia de árbitro neutro ${ }^{327}$ permite ao Estado intervir dentro da moldura predeterminada pelo sistema capitalista a fim de (re)estabelecer um equilíbrio econômico e social, permitindo a todos, em certos patamares, a possibilidade de fruir vantagens pelo acesso a um "mínimo de proteção material dos indivíduos". Além do que essa intervenção em um sistema capitalista é essencial para a redistribuição ao menos parcial da renda sob a forma de direitos sociais - bens e serviços, esses inalcançáveis às classes populares, caso o acesso fosse propiciado exclusivamente pela via do mercado ${ }^{328}$.

O elemento - autonomia ${ }^{329}$ - do Estado diz respeito, na verdade, a uma relação de "determinação" e de "determinante" dele (Estado) para com a economia em razão da qual o Estado reproduz em si a lógica social - da dialética do conflito; dando, assim, guarida a demandas das classes subalternas relativas à realização de seus interesses, mesmo que estes possam ir de encontro, em um primeiro instante, aos interesses econômicos das classes dominantes. De um lado, a autonomia relativa do Estado autoriza políticas sociais contrárias, por vezes, ao poder econômico das classes dominantes; de outro, essa mesma autonomia, ao permitir complexas consertações envolvendo os interesses das classes sociais, obsta que seja posto em xeque o poder político das classes dominantes e, nessa linha, o Welfare State é exemplo histórico mais bem acabado da operabilidade dessa característica.

Apresenta-se aqui a razão de ser do $E \operatorname{stado}^{330}$ no ínterim do modo de produção capitalista, enquanto fator de ordem - política - nos conflitos de classes, bem como fator de ordem global - coesão da unidade. Pois se o fator "ordem política" significa a garantia da existência e da continuidade de uma formação social dividida em classes; o fator "ordem global” representa a própria organização voltada à manutenção das condições de produção e de reprodução do sistema.

\footnotetext{
${ }^{326}$ Para um conceito de Políticas Públicas pode valer daquele desenvolvido por Maria Paula Dallari, cujo foco é ação-coordenação, processo e programa de onde se depreende que "Política Pública é o programa de ação governamental que resulta de um processo ou conjunto de processos juridicamente regulados - processo eleitoral, processo de planejamento, processo de governo, processo orçamentário, processo legislativo, processo administrativo, processo judicial - visando coordenar os meios à disposição do Estado e as atividades privadas, para a realização de objetivos socialmente relevantes e politicamente determinados. Como tipo ideal, a política pública deve visar à realização de objetivos definidos, expressando a seleção de prioridades, a reserva de meios necessários à sua consecução e o intervalo de tempo em que se espera o atingimento dos resultados." Bucci, Maria Paula Dallari. O Conceito de política pública em direito. In: . Políticas

Públicas. Reflexões sobre o conceito jurídico. São Paulo: Saraiva, 2006, p.39.

${ }^{327}$ Faleiros, Vicente de Paula. A política social do Estado capitalista. $11^{\mathrm{a}}$ ed. São Paulo: Cortez, 2008, p. 48/49.

${ }^{328}$ Borón, Atilio. A sociedade civil depois do dilúvio neoliberal. In: Sader, Emir; Gentili, Pablo (org). PósNeoliberalismo...Op.Cit., p. 81.

${ }^{329}$ Poulantzas, Nicos. Poder político e classes sociais...Op. Cit., p. 186/188.

${ }^{330}$ Poulantzas, Nicos. Ibid, p. 47/54.
} 
Esses fatores se apresentam sobre três modalidades basicamente: i) econômica, ii) ideológica, iii) política propriamente dita, de modo que as duas primeiras são sobredeterminadas pela última "a que diz respeito à luta política de classes -, na medida em que constituem modalidades do papel global do Estado - fator de coesão da unidade de uma formação: este papel global do Estado é um papel político. (...)Estas diversas funções particulares do Estado, mesmo as que não concernem diretamente ao nível político em sentido estrito - o conflito de classes - não podem ser teoricamente apreendidas senão na sua relação, quer dizer, inseridas no papel político global do Estado. Com efeito, este papel reveste de um caráter político, no sentido de que mantém a unidade de uma formação no interior da qual as contradições entre os diversos níveis se condensam em uma dominação política de classe. "331

As funções (econômica, justiça, por exemplo) “constituem funções políticas, na medida em que visam, em primeiro lugar, a manutenção da unidade de uma formação social,

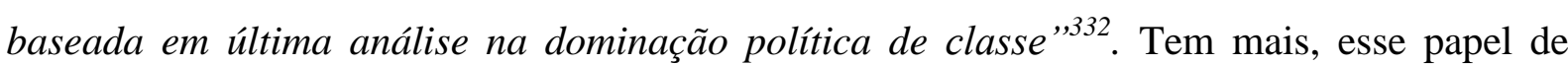
"sobredeterminação" da política quando comparada às demais funções estatais é indicativo de que a econômica por si só é insuficiente para angariar a consertação social de modo que esta é tarefa precípua do Estado enquanto fator de coesão de uma sociedade dividida em classes. Nesta linha, cabe um aviso, não se pode confundir o Estado, fator de coesão, com suas funções. Tal distinção é relativamente tranquila quando se compara o Estado Liberal e o Welfare State, pois aquele, apesar de ter uma função econômica (basta ver os escritos de Marx sobre a legislação no tocante às manufaturas), ela não é preponderante, o que impera, de fato, é a sua função política - "Estado Polícia”.

Voltando ao fenômeno da ampliação do Estado Capitalista propriamente dito ${ }^{333}$, denota-se que sua legitimação se valida pelo mecanismo de concessões e mais do que isso ela

\footnotetext{
${ }^{331}$ Poulantzas, Nicos. Poder político e classes sociais...Op. Cit., p. 48 e 51.

${ }^{332}$ Poulantzas, Nicos. Ibid, p. 52.

${ }^{333}$ Coutinho, Carlos Nelson. Contra a corrente. Ensaios sobre democracia e socialismo. $2^{\text {a }}$ ed. São Paulo: Cortez, 2008, p. 40/47.

Antes de penetrar nos domínios dos direitos sociais, cabem algumas considerações quanto ao Estado, sobretudo na passagem do Estado liberal ao social. Para compreender os direitos sociais, no fundo, há de se avançar no conceito de Estado, ao longo da história, que foi trabalhado no capítulo I, mas que é bom retomar alguns de seus pontos. Foi dito que há três concepções de Estado dentro do marxismo e cada qual colhe um aspecto do estado distinto dos demais, mas que nenhuma delas é exaustiva quanto à relação entre Estado e economia em face da sua mutabilidade ao longo do processo histórico. A concepção de Pasukanis, adotada no capítulo II, volta-se, precipuamente, para a gênese lógico-histórica da separação entre Estado e sociedade civil, a qual se amolda aos limites do Estado liberal, cujo escopo é de não criar obstáculos ao liberalismo econômico e ao individualismo, tem como legado maior a dissociação da forma jurídica de seu conteúdo originário, vindo a informar a quase totalidade das relações sociais - econômica, política, afetiva, etc.

Do capítulo I, extraem-se os limites do Estado liberal os quais se mostraram insuficientes para a compreensão dos direitos sociais, de forma que até o conceito de Estado teve de ser estendido, dando ensejo ao Estado social e
} 
espelha a correlação de forças existentes na sociedade, de modo a atender ou não as reivindicações das classes subalternas, pois "o avanço da democratização política é, ao
mesmo tempo, condição e resultado de um processo de transformação também nas esferas
econômica e social". Contudo, não se pode olvidar que as conquistas de direitos sociais no

é justamente aqui entram as considerações de Poulantzas. De plano, cabe um parêntese: este trabalho não objetiva traçar um comparativo entre Pasukanis e Poulantzas e muito menos conciliá-los, que, dentre as diferenças, pode-se ressaltar: i) o escopo de cada autor: o primeiro, em TGDM, fez uma analise sociológica do direito e mostrou que esse mesmo direito se exaure na sociedade capitalista; o outro aprofundou os estudos da superestrutura jurídica e estatal tendo em vista a passagem ao socialismo nas sociedades capitalistas avançadas; ii) tratamento que cada autor outorga ao direito: Se para Pasukanis, a chave para a compreensão do direito está na analise da sua forma mais desenvolvida, da qual se é possível compreender seus estágios anteriores, na esteira da metáfora do estudo da anatomia do homem se entende a anatomia do macaco; para Poulantzas, ao reverso, trata-se de construir conceitos de direitos cada qual relacionado a um determinado modo de produção, sendo que a chave para a investigação do direito moderno reside no estabelecimento de sua localização no conjunto complexo das estruturas de um modo de produção e de sua formação. Para ilustrar a polêmica sem, no entanto, enveredar por esse caminho, pode-se citar o próprio Poulantzas que discorrendo sobre o direito capitalista, afirmou: "Também um certo marxismo fundamentou essa especificidade do sistema jurídico capitalista na esfera de circulação do capital e das trocas mercantis: sujeitos jurídicos abstratos quando livre trocadores de mercadorias, indivíduos formalmente livres e iguais, troca equivalente e valor de troca abstrato etc. Ora não é no interior dessa esfera que se pode apreender a especificidade da lei e do direito capitalistas. A especificidade (...) deve ser procurada na divisão social do trabalho e nas relações de produção. São elas que dão a violência o lugar e o papel que desempenham no capitalismo (...). Esse sistema jurídico axiomatizado constitui o quadro de coesão formal de agentes totalmente despojados de seus meios de produção, desenhando assim os contornos de um espaço estatal relativamente separado das relações de produção. A formalidade e a abstração da lei estão em relação primeira com os fracionamentos reais do corpo social na divisão social do trabalho, com a individualização dos agentes em andamento no processo de trabalho capitalista".

Feita essa marcação de ordem conceitual, pode-se colher de Poultantzas o seu conceito de Estado que se forja a partir das relações de classe é também por ela influenciado, de forma que o Estado não é um autômato, cindido em absoluto da sociedade civil nem um simples instrumento de classe, ele é, na verdade, uma via de mão dupla a condensar materialmente as relações de força. Isso se faz visível na obra O Estado, O Poder e o Socialismo quando o autor trata da questão da lei/direito enquanto um dos elementos constituidores da materialidade institucional do Estado. Poulantzas, na esteira de Weber, afirma que "a violência física monopolizada pelo estado sustenta permanentemente as técnicas de poder e os mecanismos do consentimento, está inscrita na trama dos dispositivos disciplinares e ideológicos, e molda a materialidade do corpo social sobre o qual age o domínio, mesmo quando essa violência não se exerce diretamente".

Para o autor, em franca dissonância com os estudos de Foucault e Bourdieu que deslocam o tema da repressão, respectivamente, para a disciplina e para o simbólico, a lei exerce dois papéis: i) o de organização da repressão tanto nos sentido negativo como positivo, ii) a criação do consenso. Quanto ao primeiro, a violência legal, presente deste a origem do sistema capitalista, é determinante para a análise do autor e não se limita a última ratio, visível apenas quando da falha dos outros aparelhos ideológicos. A violência é onipresente atuando como condição de existência e de garantia do sistema capitalista. O segundo elemento, este decisivo para o caminhar do trabalho, está imbricado com muitas das ações do Estado - intervenções econômicas - que transcendem o âmbito repressivo e ideológico vindo a incorporar, sobretudo, os ganhos políticos da luta de classes, pois "as classes dominadas encontram na lei uma barreira de exclusão e igualmente a designação do lugar que devem ocupar. Lugar que é também lugar de inserção na rede político-social, criadora de deveres -obrigações e também de direitos, lugar cuja posse imaginaria tem conseqüências reais sobre os agentes." Eis aqui os domínios dos direitos sociais que "face à luta da classe operaria no plano político, esse direito organiza o quadro de um equilíbrio permanente de compromisso imposto às classes dominantes pelas classes dominadas". (...) Esse papel da lei depende da relação de força entre as classes (...) A axiomática jurídica permite a previsão política das classes dominantes (...) ela constitui igualmente o suporte de um cálculo estratégico pois inclui, nas variáveis de seu sistema, o fator de resistência e luta das classes dominadas." Poulantzas, Nicos. O Estado, o poder, o socialismo...Op. Cit., p. 91, 94, 97/98 e 104.

Para a demarcação da distinção entre Poulantzas e Pasukanis, vide: Motta, Luiz Eduardo. Direito, Estado e Poder: Poulantzas e o seu confronto com Kelsen. 2008, Caxambu. Marxismo e Ciências Sociais. São Paulo: Anpocs, 2008. Disponível

em:

http://200.152.208.135/anpocs/trab/adm/impressao_gt.php?id_grupo=7\&publico=S\&PHPSESSID=52867e2ae18 fb529c70b893e940c8263. Acessado em 07/06/09. 
interior da ordem capitalista estão imbricadas com dois fatores centrais: i) concretização da ordem político-democrática, ii) alteração da dinâmica de acumulação capitalista, em que se observa à mutação do padrão de acumulação - da mais valia absoluta para a relativa, que permitiu "harmonizar" lucros e salários.

No campo econômico, a ser detalhado no item subsequente, desde já é plausível colocar a seguinte assertiva: os direitos sociais e a lógica capitalista são elementos inconciliáveis a longo prazo, pois o salário é fruto da correlação de forças entre as classes, cujo quantum é estabelecido no interior de pontos extremos - reprodução do trabalhador e lucro/investimento. Ademais, tais limites são significativos, porquanto denotam não apenas a impossibilidade do desmonte completo do Welfare State, como também na superação da ordem capitalista vigente.

$\mathrm{Na}$ seara política, os direitos sociais clamam por decisões de políticas públicas, decisões essas assentadas em dois elementos: i) seleção de demandas sociais; ii) conciliação destas com as demandas de outros setores, cujo resultado final leva à conjugação dos direitos sociais com os interesses da reprodução do capital.

Frise-se uma vez mais que o fim último do Estado remete ao bom funcionamento do sistema capitalista, haja vista que concessões de curto prazo servem de substrato à estratégia de longo prazo voltada à sustentação da acumulação sob a hegemonia da burguesia monopolista. ${ }^{334}$ Desse modo, as funções econômicas enquanto carro-chefe de sua atuação corroboram para ampliar a contradição inicial do próprio Estado. Este movimento é perceptível quando se voltam os olhos aos limites da ação estatal ${ }^{335}$, qual seja: "a não intervenção específica no sólido núcleo das relações de produção capitalistas”, núcleo esse complementado por áreas outras afins tais como a circulação, a repartição, o consumo e a gestão da moeda, e esses limites estruturais do sistema capitalista dão o tom das intervenções do Estado que são, em sua maioria, intervenções a posteriori, visando a contornar os efeitos contraditórios do processo de valorização do capital.

Assim, dentro da ordem capitalista consolidada, o Estado como resultante do “movimento das classes sociais e suas projeções" tem aí um papel fundamental, pois tem a incumbência de "assegurar as condições da reprodução social no âmbito da lógica monopólica ao mesmo tempo em que deve legitimar-se para além desta fronteira - donde

\footnotetext{
${ }^{334}$ “O Estado é hegemonia e dominação. A hegemonia representa sua capacidade de orientar o conjunto da sociedade, de arbitrar os conflitos entre as classes e os conflitos de classe, de estabelecer uma certa coesão social. Pela dominação, o Estado impõe a repressão, a força e manu militari, destrói as oposições e resolve os conflitos". Faleiros, Vicente de Paula. A política social do Estado capitalista...Op. Cit., p. 52.

${ }_{335}$ Poulantzas, Nicos. O Estado, o poder, o socialismo...Op. Cit., p. 220/222.
} 
ressalta o seu traço intervencionista e a sua relativa permeabilidade a demandas extramonopolistas incorporadas seletivamente com a tendência a neutralizá-la. Este núcleo elementar de tensões e conflitos aparece organizado na sua modalidade típica de intervenção sobre a questão social, conformada nas políticas sociais - intervenção que a fragmenta $e$ problemas autonomizados, mas que se realiza sistemática, continua e estrategicamente, em respostas que transcendem largamente os limites da coerção sempre presente. "336

Ou seja, em uma ponta, objetiva-se a garantia do sistema (de acumulação baseada na força da propriedade privada); na outra, a garantia do clima social como imperativo essencial à acumulação.

Esta concatenação, basicamente, é processada sob a forma de dois tipos de despesas $^{337}$, a saber: i) as de capital social que são constituídas por "investimentos sociais" e por "consumo social", tais como os seguros sociais, ambos dirigidos à produtividade e à diminuição do custo de reprodução da força de trabalho, cujo mote final é o incremento da acumulação privada; ii) as sociais que têm por função a manutenção da harmonia social, na figura do Estado legitimado, como é exemplo da assistência social. Frise-se que essa separação das despesas públicas, conforme as funções do Estado, é apenas para fins didáticos, dado que, na realidade, muitas delas se prestam a ambas as funções, sendo o exemplo mais emblemático o da própria assistência social de importância significativa para as economias de diversos municípios brasileiros.

Estabelecidas estas premissas correlacionando o Estado e a questão social, pode-se avançar agora pela "democracia burguesa", pelos seus limites e possibilidades com base na análise da atuação estatal, como engrenagem de mediação do conflito capital e trabalho e que atende pelo nome de direitos sociais, funcionalizados por meio de políticas públicas. Isso porque as demandas sociais ${ }^{338}$ formuladas por classes ou grupos sociais percorrem os caminhos da positivação jurídica e de sua efetivação, na medida em que são colhidos pelo Estado e pelas instituições paraestatais. Tal percurso é indiciário da correlação entre direitos e história da humanidade e não de uma ordem natural preestabelecida, tal qual aquela propugnada na origem pelo jusnaturalismo que findou em um rol limitado de direitos que gravitava em torno do direito de propriedade, tendo por consequência a (re)criação de uma nova desigualdade - material e não mais a do tipo hierárquica/estamental feudal.

\footnotetext{
${ }^{336}$ Netto, José Paulo. Capitalismo monopolista e serviço social. $6^{\text {a }}$ ed. São Paulo: Cortez, p.80.

${ }^{337}$ Faleiros, Vicente de Paula. A política social do Estado capitalista...Op. Cit., p.78.

${ }^{338}$ Coutinho, Carlos Nelson. Contra a corrente...Op. Cit., p. 53/54.
} 
O ponto de partida é, sem dúvida, a democracia política que, simultaneamente, legitima o sistema capitalista (do tipo monopolista) e vulnerabiliza o Estado aos diversos pleitos das demais classes sociais, de modo que o conflito capital/trabalho incorpora-se ao âmbito estatal sob o mecanismo de formulação e implementação de políticas públicas. ${ }^{339}$

Em linhas gerais, as demandas sociais emergem via mobilizações e pressões que redundam em conquistas e em reconhecimentos de direitos pelo Estado de modo a tornar a lei ${ }^{340}$ o "centro nervoso" desse mecanismo, não só porque ela é o núcleo regulador das transformações, na qual a Constituição é o exemplo mais vistoso, como também é ela quem regula "o exercício do poder político pelos aparelhos do Estado e do acesso a esses aparelhos". Esta centralidade da lei enquanto instrumento necessário e imprescindível ao Estado na sua função de canalizar e amortizar as disputas políticas tem por pano de fundo a separação entre Estado e sociedade que, no limite, serve para ocultar a essência de classe do Estado a ponto dos "agentes da classe economicamente dominante (burguesia) não se confundirem com os mantenedores e agentes do Estado."

Mesmo assim, não se pode perder de vista o fato de que todas as modalidades de luta (institucionalizadas - sindicato e partidos ou não) têm como consequência significativas vitórias que são, na verdade, "inflexões no projeto burguês de dominação"341. Estas conquistas materializam-se em políticas públicas, para além da mera coerção de forma a amoldar democracia formal com demandas sociais que, no limite, resulta na estabilização da sociedade. Isso se deu pelo "redimensionamento histórico da questão social", pois a burguesia teve de articular um projeto político social que, ao mesmo tempo, fizesse frente ao de seu oponente e que atendesse "às exigências da nova dinâmica econômica" a fim de poder instrumentalizar-se nas disputas políticas em torno do controle da sociedade.

De um lado, seu projeto combinou "conservadorismo e reformismo integrador" em uma "incorporação seletiva" de cunho pragmático com vista à mudança de foco da questão social, neutralizando seu potencial político pela técnica e pela ética, posto que elidem "a questão da historicidade da organização social" e viabilizam a legitimidade de seu projeto, de modo a consolidar seus objetivos - "de reprodução enquanto classe dominante". Nesse caldo, a questão social $^{342}$, objeto de intervenção estatal, volta-se ao ocultamento da condição de classe no interior do Estado pela incorporação de demandas, ao estabelecimento do consenso, e a maximização, direta ou indireta, dos lucros. Isso se dá, pois a intervenção estatal realiza-se

\footnotetext{
${ }^{339}$ Netto, José Paulo. Capitalismo monopolista e serviço social...Op.Cit.,p. 29.

${ }^{340}$ Poulantzas, Nicos. O Estado, o poder, o socialismo...Op. Cit., p. 103.

${ }^{341}$ Netto, José Paulo. Capitalismo monopolista e serviço social...Op.Cit., p. 58/62.

${ }^{342}$ Netto, José Paulo. Ibid, p.30/32.
} 
de forma "fragmentária, parcial e categorizada", sob o nome de "políticas sociais", atacando as consequências da questão social na medida que os efeitos são imputados ao indivíduo, desviando, assim, da lógica que a enseja.

Tratando, dessa maneira, a questão social - pela ratificação seja do individualismo ou de um corporativismo setorial de interesses limitados e em articulação com a burocracia estatal -, o projeto da burguesia propugna pela neutralização do potencial político democrático de modo que até mesmo um aviso dado por Rousseau permanece mais atual do que nunca, qual seja: a democracia pode ser obstada pelo pluralismo na ausência do predomínio da vontade geral e do interesse público ${ }^{343}$.

Desse alerta, cabe uma derivação ${ }^{344}$ importante: o interesse público não é sinônimo de Estado, essa equiparação foi útil ao modus operandi do capitalismo, dado que o primado do mercado não permitiu desenvolver formas de sociabilidade e, por conseguinte, de fortalecimento do espaço público. Isso porque o sistema capitalista é sabedor de sua limitação, qual seja: a de que somente é capaz de conviver com democracias políticas, em virtude da sua natureza contraditória edificada na extração da mais valia e na expropriação do produto do trabalho. Nessa linha, é correta a percepção de $\operatorname{Wood}^{345}$ - a de que o "capitalismo humanista" é deveras dificultoso, dado seus imperativos de racionalidade econômica, gravitando em torno do lucro, da acumulação e da competição, e estaria a exigir uma intervenção do Estado que suplantaria o mecanismo do Welfare e transcenderia os limites das fronteiras nacionais.

As ordens de constatações acima exacerbam a premente tarefa ${ }^{346}$ da humanidade: tentativa de conciliar Estado e sociedade fortes, para que o interesse público seja o carro-chefe desse sinergismo. Para isso, de plano, há de se redefinir a própria noção do público por meio de uma proposta democrática tendente a lograr um conceito de espaço público pela via de aumento dos mecanismos de participação democrática, socialização da política, a fim de que o interesse público seja prevalente nas esferas da vida social e política. Assim, quiçá, ao menos, os direitos sociais possam lograr um patamar de fruição semelhante ao dos direitos civis e políticos.

Cabem aqui um esclarecimento e uma reiteração, quando se fala de direitos sociais, nos limites dessa dissertação, há de se pensar sempre dentro do sistema capitalista, jamais se pretende identificá-los a qualquer modalidade de aspiração emancipatória da humanidade

\footnotetext{
${ }^{343}$ Coutinho, Carlos Nelson. Contra a corrente...Op. Cit., p.31.

${ }^{344}$ Borón, Atilio. O Pós-Neoliberalismo é uma etapa em construção. (In) Sader, Emir; Gentili, Pablo (org). PósNeoliberalismo...Op.Cit., p.193/194.

${ }^{345}$ Wood, Ellen Meiksins. Democracia contra capitalismo...Op.Cit., p. 246.

${ }^{346}$ Coutinho, Carlos Nelson. Contra a corrente...Op. Cit., p.145/146.
} 
tendo nos direitos sociais um fim último; a maior extensão possível de pensá-los seria numa espécie de "cidadania social" que não é sinônimo de revolução, nem de socialismo, etc...

Feita esta intervenção, luzes sobre algumas das considerações postas acima foram lançadas por Van Parijs, cujo pensamento tenciona para um ideal de "democracia radical" e que vê no desenvolvimento do capitalismo uma oportunidade de introduzir critérios de justiça social a fim de garantir a todos uma "liberdade real", ou seja, propugna o autor para uma alternativa ao sistema capitalista. Seu pensamento gestado em mais de 25 anos de estudos e de pesquisa culmina na ideia e no desenvolvimento do programa chamado de renda básica e que tem por eixo, duas fontes de inspiração ${ }^{347}$. A primeira delas - a curto prazo - voltava-se para o equacionamento da política econômica e social no contexto europeu da década de 1980, baseado no crescimento econômico constante e acelerado com altas taxas de desemprego; a outra fonte - a longo prazo - dirige-se a um projeto de sociedade pensado a partir da realidade histórica atual para além dos esquemas neoliberal e social-democrata.

O que interessa para os limites deste trabalho é justamente a segunda reflexão de Van Parijs, reflexão essa de cunho teórico e de importância singular quando se pensa em uma alternativa para o que hoje está posto. A partir dos anos de 1980, segundo o autor, a tradição marxista-socialista havia, em linhas gerais, perdido as ilusões quanto a possibilidade do socialismo opor-se ao capitalismo em matéria de eficiência, pensada no sentido de desenvolvimento efetivo e rápido das forças produtivas ${ }^{348}$.

Dentro deste contexto, Van Parijs desenvolveu o projeto da renda básica, valendo-se do dinamismo ínsito ao sistema capitalista. A ideia é basicamente a seguinte: “Com o progresso da produtividade, graças ao dinamismo do capitalismo, com o desenvolvimento das forças produtivas, esta renda básica poderia aumentar gradualmente em termos absolutos e em termos proporcionais ao produto total, até que, no limite, constituiria a parte maior do rendimento disponível para a população do país, com salários e benefícios reduzidos ao papel de dinheiro para pequenos gastos, um pequeno rendimento adicional marginal". 349

Assim, o programa renda básica (composto em parte sob a forma de serviços gratuitos de saúde e de educação e, em parte, em espécie - sob a forma de uma renda

\footnotetext{
347 Van Parijs, Philippe. A renda básica: Por que, como e quando nos países dos hemisférios norte e sul? Econômica, Rio de Janeiro, v.4, n.1, jun/02, p.76/78.

348 A base dessa constatação vem da tradição marxista ortodoxa de que o socialismo se justificaria pela sua maior eficiência quando se comparado ao capitalismo, "porque permitiria um desenvolvimento mais rápido das forças produtivas e assim proporcionaria mais rapidamente as condições que possibilitariam o comunismo, isto é, de uma sociedade na qual todos os bens são distribuídos em função das necessidades, e assim cada um fica liberado da compulsão de trabalhar." Van Parijs, Philippe. Ibid, p. 77.

${ }^{349}$ Van Parijs, Philippe. Ibid, p.78.
} 
monetária) aparta-se dos programas sociais tradicionais, na medida que, por ser incondicionado, tem o mérito de romper tanto com a focalização quanto com a armadilha da dependência do sistema (clientelismo) para aquelas pessoas com pouca ou nenhuma qualificação. Pois, se de um lado, o rompimento com a focalização dos programas tradicionais - são, em regra, restritos a uma condicionalidade: o fato de a pessoa estar excluída do mercado - viabiliza a não estigmatização dos beneficiários com a transferência de renda, dado se tratar de um direito de todos e não mais uma forma de assistência dentro de uma rede de seguridade social.

De outro lado, o programa renda básica não se depara com a questão da exclusão ínsita aos programas tradicionais, no qual o (re)ingresso ao mercado de trabalho, no mais das vezes, significa a perda do benefício e isso, na verdade, se torna uma armadilha para aquelas pessoas com baixa ou nenhuma qualificação, dado que não conseguem se desvencilhar do programa. Tal armadilha não ocorre com a renda básica, na medida que por ser um benefício não atrelado ao trabalho, o trabalho funciona como uma forma de crescimento e de desenvolvimento pessoal e não mais como "um castigo" ou uma penalização representada pela saída do indivíduo do programa social.

O parágrafo anterior não só introduz um conceito de renda básica como também esboça seus pilares e põe a questão do por que da necessidade de uma renda básica. A partir da definição de renda básica, qual seja: "renda paga por uma comunidade política a todos os seus membros individualmente, independentemente de sua situação financeira ou exigência de trabalho" ${ }^{350}$, Van Parijs desenvolve no texto intitulado - Renda básica: renda mínima garantida para o século XXI? - toda uma argumentação de cunho econômico, voltada precipuamente para introduzir o programa renda básica na sociedade. Para os limites desta dissertação, o relevante é justamente o contraponto traçado pelo autor entre o programa renda básica e os programas sociais de matizes liberais e social-democratas.

Van Parjis afirma que a força de sua proposta reside na solidariedade de dois fatores (da incondicionalidade tanto da situação financeira como da situação laboral) enquanto forma de tratar a pobreza e o desemprego. Para o autor, a independência da situação da renda do beneficiário desmonta com a armadilha do desemprego de duas maneiras. A primeira delas reside no fato de que o benefício advindo do sistema de renda básica não cessa quando um de seus beneficiários aceita um determinado emprego, tal como se daria em um sistema

\footnotetext{
${ }^{350}$ Van Parijs, Philippe. Renda básica: renda mínima garantida para o século XXI? Estud. av, São Paulo, vol.14, $\mathrm{n}^{\circ} 40$, sept/dec 2000. Disponível em: http://www.scielo.br/scielo.php?script=sci_arttext\&ped=S010340142000000300017. Acessado em 02/12/09.
} 
tradicional atrelado à renda. "Comparado a sistemas condicionados à verificação da situação financeira dos beneficiários que garantem o mesmo nível de renda mínima, este abre perspectivas reais para pessoas pobres que têm bons motivos para não assumir riscos. Isso significa remover um aspecto da armadilha do desemprego comumente associado a sistemas convencionais de benefícios, um aspecto ao qual os assistentes sociais geralmente são muito mais sensiveis do que os economistas." 351

A segunda armadilha do desemprego associada aos sistemas tradicionais encontra-se justamente no fato de que no ponto mais baixo da pirâmide social os benefícios podem compensar em muito o rendimento advindo de um emprego mal remunerado, essa lógica não colhe o sistema de renda básica, justamente porque "uma pessoa pode manter o valor integral de sua renda básica, quer esteja trabalhando ou não, quer seja rica ou pobre, ela com certeza estará numa situação melhor quando estiver trabalhando do que quando estiver desempregada" ${ }^{, 352}$. E mais, esse duplo rompimento com a armadilha do desemprego dota o indivíduo de um poder de barganha inexistente nos modelos tradicionais, o que acaba refletindo no tipo de trabalho a ser ofertado no mercado, haja vista que "empregos desagradáveis" não mais seriam oferecidos, dando ao trabalho um contorno, assentado agora na perspectiva de enriquecimento e de fomento ao progresso do indivíduo.

Com relação à segunda não condicionalidade - sem exigência ao trabalho - Parijs afirma que ela só tem relevância e densidade se estiver associada com a primeira não condicionalidade - sem exigência de renda -, pois esta conjugação evita tanto a exploração como a exclusão inaceitáveis. "Assim, como a não-condicionalidade ao trabalho evita que a não-condicionalidade à situação financeira sustente de maneira inaceitável a exploração (o que a segunda faria ao subsidiar empregos indignos e mal remunerados, aceitos sob a ameaça da perda do benefício), de modo semelhante a não-condicionalidade à situação financeira evita que a não-condicionalidade ao trabalho fomente de maneira inaceitável a exclusão (o que a segunda faria ao nos incitar a não mais considerar como problemático um sistema que exclui firmemente o menos produtivo de qualquer participação no trabalho, eliminado de maneira efetiva empregos de baixa produtividade)". 353

O que se depreende da correlação acima, é o próprio núcleo do programa renda básica como mecanismo que atinge os domínios do trabalho mal remunerado, porquanto sua preocupação basilar é a de proporcionar acesso a uma atividade remunerada que faça sentido,

\footnotetext{
${ }^{351}$ Van Parijs, Philippe. Renda básica: renda mínima garantida para o século XXI?...Op.Cit.

${ }^{352}$ Van Parijs, Philippe. Ibid.

${ }^{353}$ Van Parijs, Philippe. Ibid.
} 
impondo ao trabalho uma conotação diversa dos esquemas tradicionais, outorgando-lhe a importância que ele merece, tendo em vista lograr uma concepção de justiça social que transcende o direito a uma renda e direciona-se à questão do acesso a uma atividade que enriqueça e fomente o progresso do indivíduo. E mais, do excerto acima, extrai-se que o programa renda básica ${ }^{354}$ tem o mérito de suplantar os esquemas assistencialistas de matiz liberal (como é o caso, por exemplo, do bolsa-escola bem como de sua derivação e ampliação, bolsa-família com a imposição de condicionantes que levam à focalização do programa e de questionáveis resultados quando se pensa no rompimento do ciclo da pobreza e na integração dos beneficiários no mercado de trabalho) na medida que propugna assegurar um nível mínimo de renda, apto a cobrir as necessidades elementares do ser humano voltadas à sua sobrevivência, servindo de instrumento de combate à miséria e de expressão latente de um direito à cidadania - direito de participar da renda da nação, distinta de qualquer correlação imediata com o mundo do trabalho/emprego.

A questão que fica em aberto para o caso brasileiro remonta justamente, tal como notou Parijs, a patente impossibilidade de se introduzir aqui um programa de renda universal em face da situação de subdesenvolvimento e das mazelas aí resultantes, devendo, então, a curto prazo, iniciar com programas de cunho seletivo que podem, no limite, não suplantar as

\footnotetext{
${ }^{354}$ Suplicy, Eduardo. Da renda mínima a renda básica no Brasil. (In) Correia, Marcus Orione Gonçalves; Correia, Érica Paula Bacha (coord). Direito previdenciário e Constituição. São Paulo: LTr, 2004, p. 80/81. Interessante trazer aqui algumas das reflexões de Bauman, que ao tudo indica partidário do programa renda básica, ao adentrar na especificidade da forma como o debate acerca do assunto fora conduzido. Afirma o autor que os argumentos favoráveis ao programa gravitam em torno de considerações afetas aos direitos humanos sob a ótica de que o direito à vida é um bem inalienável e antecede qualquer outro direito, ou sob o enfoque do dever do Estado (Social) como forma de política social de combate a crise do emprego, ou seja, de matiz mais econômica. Ambas as linhas de argumentação são legítimas, válidas e superam qualquer quadratura assistencial liberal hoje vigente; todavia, segundo Bauman, o ponto mais relevante não recebeu a devida atenção, reside ele na sua importância política pelo fato do programa renda básica ter um "papel crucial na restauração do espaço público/privado perdido. Em outras palavras, no fato de ser uma condição sine qua non do renascimento e da república plenas, ambas concebiveis apenas na companhia de pessoas confiantes, pessoas livres de medo existencial-pessoas seguras."

Essa ótica de ponto de partida vê o programa renda básica como instrumento apto senão erradicar, pelo menos a mitigar, parte substancial da insegurança existencial do cotidiano humano tendo, assim, uma utilidade à construção da república: "pela remoção da horripilante mosca da insegurança do doce ungüento da liberdade. Se algo deve ser limitado, são os riscos envolvidos na pratica da liberdade. Mas essa limitação de riscos e prejuízos é precisamente o objetivo mais crucial de uma renda básica. Quando (se) esse objetivo for alcançado, homens e mulheres não mais temerosos de usar sua liberdade poderão encontrar tempo, vontade e coragem para construir sentidos cada vez mais humanos da sua humanidade, para examinar e selecionar formas de vida que sejam ao mesmo tempo satisfatórias e racionais."

O interessante dessa perspectiva é inverter a lógica prevalente e apor o direito ou, pelo menos parcela dele, a serviço da política, pois esta é a única capaz de ampliar os contornos da liberdade. No mais, fica o alerta recorrente desta dissertação: uma sociedade temerosa da política finda por reduzi-la a lei e esta já deu mostras mais do que suficientes, ao longo da história, do que é capaz de fazer com a democracia, ou melhor, com seu germe e possibilidades eventuais. Bauman, Zygmunt. Em busca da política. Trad. Marcus Penchel. Rio de Janeiro: Jorge Zahar, 2000, p.183/192. Ver principalmente p. 185 e 191.
} 
armadilhas do desemprego e da dependência que eles mesmos dão origem e fomentam. E isso, aliado ao movimento da seguridade social na década de 1990 e de 2000, conforme veremos abaixo, cria-se um tremendo obstáculo a ser removido, caso o propósito seja mesmo o de suplantar os programas convencionais de transferência de renda.

\section{2) Segunda aproximação - enfoque econômico}

Neste tópico ${ }^{355}$, para os objetivos do trabalho, serão ventilados alguns aspectos da economia, dentre os quais, a contradição inerente ao sistema capitalista expressa pela lei da baixa tendencial da taxa de lucro que explica, em grande medida, o móbil da ação estatal enquanto instrumento para se contrapor a essa tendência, bem como as modificações estruturais do modelo de acumulação e sua primeira grande crise - final da década de 2000 . Não se irá remontar todo o exposto no capitulo I quanto à passagem do Welfare para o Estado Liberal e sim fazer uma incursão na crise no que tange aos domínios dos direitos sociais e, para tanto, é necessário primeiro avivar a contradição elementar do sistema.

2.1) Remontando a contradição elementar do sistema

A literatura marxista ${ }^{356}$ aponta como um dado comum o fato das crises serem intrínsecas ao sistema capitalista, haja vista que o processo de valorização, como traço característico da acumulação, realiza-se sob constantes desequilíbrios e tensões. Esta mesma literatura diverge quanto a seu elemento desencadeador, para uns impera a tese do subconsumo, para outros a da superprodução. Nesta discussão, interessa verificar a estrutura

\footnotetext{
355 Alguns conceitos importantes para o presente item, extraídos de Mandel, Ernest. Tratado de economia marxista.Tomo I. Mexico: Ediciones Era, 1969, p. 122/124 e 142/143.

Capital constante - parte do capital que conserva seu valor no processo produtivo pela sua incorporação em valor nos produtos terminados, vide como exemplo, matéria prima, maquinas, etc..

Capital variável - parte do capital empregada na compra da força de trabalho, capital esse que será acrescido com a mais valia dos trabalhadores.

Composição orgânica do capital - relação entre capital constante e capital variável.

Taxa de mais valia - indicador que revela o grau de exploração da classe trabalhadora, sendo ela uma relação entre mais valia e salários. A mais valia representa a diferença entre o valor criado pela força de trabalho e o valor dessa própria força, ela se realiza de duas formas básicas, a saber: i) absoluta que é obtida pelo prolongamento da jornada de trabalho, ii) relativa que se vale do aumento da produtividade do trabalho, via emprego de máquinas novas, novos métodos de trabalho, etc, reduzindo, assim, o tempo de trabalho necessário para produzir o equivale ao salário do trabalhador.

Taxa de lucro - relação entre mais valia e o conjunto dos capitais investidos (constante e o variável).

${ }^{356}$ Fernandes, Ana Elizabete Simões da Mota. Cultura da crise e seguridade social: um estudo sobre as tendências da previdência e da assistência social brasileira nos anos 80 e 90. São Paulo: Cortez, 1995, p.33/34.
} 
elementar do sistema capitalista, cujas origens estão relacionadas à separação do produtor dos meios de produção, à concentração destes (dos meios de produção) nas mãos de uma só classe social, bem como pela sua contrapartida, a aparição de uma classe social que é detentora apenas de sua força de trabalho; cujo desenvolvimento é marcado pela concorrência e pela tendência a acumulação por meio da reutilização da mais valia na própria produção (via aquisição de máquinas ou aumento do $\mathrm{n}^{\mathrm{o}}$ de empregos), com a condição de que haja não apenas um mercado para absorver essa produção, como também uma taxa de lucro "razoável" e atrativa.

Em linhas gerais ${ }^{357}$, a base sob a qual se edifica o sistema é constituída pela produção, pela presença de um mercado livre e ilimitado, seja geográfica ou economicamente, pela existência de inúmeros centros decisórios em matéria de produção e de investimento e pela competição. A acumulação de capital passa necessariamente pelo angariamento de mercados e, para tanto, o capitalista se vale de uma ferramenta que lhe é essencial: a diminuição do preço das mercadorias. Redução esta conseguida pelo aumento da produtividade que deriva do desenvolvimento das forças produtivas, da racionalização do processo de produção, da melhora da divisão do trabalho, etc.

Em outras palavras, a essencialidade do capitalismo pode ser retirada do "aumento ilimitado da produção, a acumulação constante do capital pela capitalização da mais valia produzida durante o processo produtivo" ${ }^{\text {358 }}$. Conjuntamente com o movimento de acumulação vem à monopolização como parte indissociável da lógica do sistema, pois " $a$ incerteza do ganho capitalista implica numa necessidade de uma constante expansão dos negócios, que a seu turno depende de uma acumulação máxima de capital ${ }^{\text {359 }}$.

A partir desses apontamentos, pode-se debruçar sob um esquema bem simplificado da dinâmica do sistema sem perquerir, nesse instante, sobre outras variáveis importantes para a compreensão da complexidade do capitalismo na atualidade, tais como inflação, atuação do Estado na economia, crédito, serviços e monopólios, dentre outros, o que se propugna é reter aqui a contradição essencial do sistema.

\footnotetext{
${ }^{357}$ Mandel, Ernest. Tratado de economia marxista...Op. Cit., p. 119/121.

358 "Bajo el aguijón de la competência, el modo de producción capitalista se convierte así em el primer modo de producción em la historia de la humanidad cuya finalidad essencial es, evidentemente, el aumento ilimitado de la producción, la acumulación constante del capital, por la capitalización de la plusvalia producida durante el proprio proceso de la producción". Mandel, Ernest. Ibid, p.120.

359"La incertidumbre de la ganancia capitalista implica, por el contrario, la necesidad de uma constante expansión de los negocioss, que a su vez depende de uma acumulación máxima de capital, de uma realización máxima de benefícios". Mandel, Ernest. Ibid, p.121.
} 
A dinâmica do capitalismo ${ }^{360}$ é "eternamente" cíclica, ora desponta a fase de prosperidade, ora a de crise. Quanto à prosperidade em larga medida, verificam-se: aumento da composição orgânica do capital relacionado com a criação e a utilização de novos equipamentos, a queda da taxa de mais valia em face dos aumentos salariais e da impossibilidade de ampliar, tanto a duração como a intensidade do trabalho para além de certo limite. Pari passo ao desenvolvimento da capacidade produtiva, amplia-se a oferta no mercado de mercadorias até o ponto em que esta oferta suplanta a demanda e a magnitude desse desacoplamento mostra-se pela redução do preço das mercadorias e, por conseguinte, menor lucro.

Em outras palavras, a desarmonia entre oferta e procura faz com que parte das mercadorias torne-se invendável pelo seu valor, contendo elas tempo de trabalho desperdiçado em nível social. É importante desde já pôr em relevo que esse fenômeno é derivado, em última análise, das decisões individuais de cada capitalista que ao buscar incessantemente a acumulação, lança mercadorias em demasia no mercado e, então, surge a possibilidade da crise.

Crise essa marcada eminentemente pela "superprodução de valores de troca", na qual a totalidade das mercadorias não é vendida e não se realizando, assim, seu equivalente em dinheiro. Em face da impossibilidade da venda da mercadoria pelo seu valor ou feita ela apenas em parte, um novo ciclo produtivo em escala ampliada não pode ser iniciado, seja para um ou para o conjunto dos capitalistas e daí a interrupção do ciclo de acumulação. "Em suma, diremos que o valor deve ser não apenas produzido sob a forma mercadoria, mas também convertido à forma dinheiro" ${ }^{, 361}$, caso não se realize, tem-se a crise que, dentre seus reflexos mediatos, podem-se citar além do sobrestamento do processo produtivo, o desemprego e a não utilização dos instrumentos de produção disponível, como resultantes mais visíveis.

O dado interessante da crise, para além da queda da taxa de lucro, por paradoxal que possa parecer, é que ela permite "uma adaptação entre a quantidade de trabalho socialmente necessário e a quantidade de trabalho efetivamente despendido na produção" ${ }^{362}$. Esse ajuste, no entanto, é feito no próprio mercado, pós-produção de mercadorias, pois ao não aceitar o seu valor, pune-se o "tempo de trabalho desperdiçado". Ou seja, se por um lado, a crise representa uma forte e repentina queda da taxa de lucro; por outro, ela mesma estabelece as condições para um aumento da taxa média de lucro e para a retomada do crescimento,

\footnotetext{
${ }^{360}$ Salama, Pierre; Valier, Jacques. Uma introdução à economia política. Trad. Carlos Nelson Coutinho. Rio de Janeiro: Civilização Brasileira, 1975, p. 112/124.

${ }^{361}$ Salama, Pierre; Valier, Jacques. Ibid, p.115.

${ }^{362}$ Salama, Pierre; Valier, Jacques. Ibid, p.120.
} 
servindo, desta forma, como um "antídoto" do sistema contra a queda na taxa média de lucro. Isso porque o período de retomada é marcado, ao reverso do período de prosperidade, pela queda da composição orgânica do capital quando se retoma a atividade, seja pela contratação de mão de obra ou por colocar em funcionamento os equipamentos disponíveis; pelo aumento da taxa de mais valia, em face dos salários achatados pela crise e da possibilidade de ampliar tanto a duração como a intensidade do trabalho, e, sobretudo, porque a crise é sinônimo de "descapitalização, isto é, a destruição de uma massa de máquinas e de matérias-primas, assim como uma depreciação do capital, devida à queda de seu preço"363. Esta conjugação de descapitalização e depreciação expressa-se na queda, quer seja do volume ou no valor do capital constante e, desse modo, a crise é não só um alento para a questão da superacumulação pretérita, como também é uma nova oportunidade para o aumento da taxa media de lucro.

A descrição limpa e linear de um ciclo reprodutivo do sistema capitalista pode dar a falsa impressão de que a causa última da crise é apenas e tão somente a anarquia da produção quando, na verdade, não se pode negligenciar a contradição existente no interior da sociedade, na qual duas tendências opostas são colocadas lado a lado: a de ampliar a produção e a de restringir o consumo das massas, limitando seu poder de compra, como regra, pela limitação de renda e salários ${ }^{364}$. No interior dessa contradição é que se pode entender a crise como “impossibilidade de manter o antigo nível de valores, de preços e de taxa de lucro, com uma massa maior de capitais. É o conflito entre as condições de acumulação e de valorização do capital; esse conflito não é mais que a explicitação de todas as contradições inerentes ao capitalismo, que intervém em sua totalidade na explicação das crises: contradição entre o maior desenvolvimento da capacidade de produção e o desenvolvimento mais restrito da

\footnotetext{
${ }^{363}$ Salama, Pierre; Valier, Jacques. Uma introdução à economia política...Op.Cit., p.121.

${ }^{364}$ Mandel discorre sobre as formas e evoluções dos salários no modo de produção capitalista, correlacionandoos em função das leis de acumulação do capital nos seus ciclos de crescimento e de crises. Analisa a relação entre salários/aumento da produtividade do trabalho considerando as variações em torno do exército industrial de reserva, bem como da organização dos trabalhadores em sindicatos. Afirma autor que o aumento dos salários choca-se em determinado instante com as barreiras institucionais do sistema: readaptação de uma economia baseada no lucro, seja pela alta de preços, pelas tendências inflacionárias, pela queda dos investimentos, pela redução de empregos, pela substituição de empregados por máquinas, etc... reaparecendo, daí o desemprego o que inviabiliza um aumento real de salários, mostrando, desta forma, a impossibilidade do sistema de sobreviver com pleno emprego.

Dentro do tema produtividade do trabalho e salários, o autor ressalta o seu efeito contraditório, na medida em que: se ao olhar para os bens de subsistência, estes tendem a diminuir seu valor o que é acompanhada pela diminuição do salário relativo (relação entre jornada /produção do equivalente em salário pelo empregado), diminuindo também o valor da força de trabalho. Aos olhos dos produtos de luxo, ocorre o reverso, ou seja: há uma tendência a aumentar o valor da força de trabalho, pois novas séries de mercadorias são incorporadas ao mínimo vital. Colhe, também, um outro viés contraditório do sistema: relação entre a acumulação do capital e o volume de emprego e a tendência dos salários ao analisar a expansão do capital em busca de novas áreas a explorar. Conclui que no capitalismo há, na verdade, uma pauperização relativa, pois o aumento dos salários, no longo prazo, são, invariavelmente, inferior ao aumento da riqueza social e da produtividade média do trabalho. Mandel, Ernest. Tratado de economia marxista...Op.cit., p.130/141.
} 
capacidade de consumo das grandes massas; contradições decorrentes da anarquia da produção que resultam da concorrência, do aumento orgânico do capital e da queda da taxa de lucro" 365 .

Pela crise, mais especificamente, pelo seu significado, pode-se avançar para colher a contradição suprema do regime ${ }^{366}$ que, no fundo, é a contradição entre socialização da produção e privatização da apropriação. Pois, se, de um lado, a socialização da produção remete à universalização das relações humanas, na medida que se esvaneceu a produção para consumo próprio e a sobrevivência de cada um passa agora a depender do trabalho de todos na esteira da célebre frase "o trabalho individual é uma ínfima parcela do trabalho social".

Esta mesma socialização autoriza, ainda, o desenvolvimento sem precedentes das forças produtivas, cuja repercussão se verifica no "aumento da composição orgânica do capital, na concentração do capital, na extensão constante da base do modo de produção capitalista" 367 . De outro, as forças de mercado ditadas pela apropriação privada governam essa socialização da produção e que ao fazer do lucro seu objetivo, a apropriação privada finda por marcar o descompasso do desenvolvimento das forças produtivas, uma vez que " $a$ produção se desenvolve por saltos, não necessariamente nos setores nos quais subsistem as necessidades humanas, senão naqueles onde podem se realizar maiores taxas de ganhos",368. Esse traço leva a desproporção entre o que se produz e o que se consome e, invariavelmente, a uma crise do sistema que se faz presente justamente para recompor o equilíbrio agora num novo patamar.

E mais, essa contradição pode ser expressa em uma lei chamada de Lei da Queda Tendencial da Taxa de Lucro que singelamente é enunciada da seguinte forma: a acumulação do capital está relacionada diretamente à sua elevação da composição orgânica e em se aumentando esta, tende a reduzir a taxa de lucro, cuja significação maior é recolher em si "a contradição entre a tendência ao desenvolvimento ilimitado das forças produtivas e a conservação das relações de produção existentes". Todavia, existem fatores do próprio sistema $^{369}$ aptos a contrarrestar essa tendência, dentre eles, pode-se citar: i) aumento da taxa

\footnotetext{
365 Salama, Pierre; Valier, Jacques. Uma introdução à economia política...Op.Cit., p.123/124. Nesse trecho, Salama faz referência aos pensamentos de Mandel e de Lennart.

${ }_{366}$ Mandel, Ernest. Tratado de economia marxista...Op.cit., p.158/160.

367 'Este prodigioso desarrollo de las fuerzas productivas está implicitamente contenido en el aumento de la composición orgánica del capital, en la concentración del capital, em la extensión constante de la base del modo de producción capitalista que tiende a conquistar todo el mundo". Mandel, Ernest. Ibid, p.159.

368 "De ahí que el conjunto de la producción objetivamente socializada se desarrolle independentemente de las necesidades que ella misma ha suscitado, aguijoneada solamente por la sed de ganâncias de los capitalistas". Mandel, Ernest. Ibid, p.159.

${ }^{369}$ Mandel, Ernest. Ibid, p.155/158; ver, também, p.156. "El incremento de la composición orgánica del capital actúa igualmente em el sentido de um evilecimiento de los precios de las máquinas, y por tanto del valor del
} 
da mais valia (relativa), que pode estar relacionada com o aumento da composição orgânica do capital - aumento da produtividade. Todavia, elas não têm comportamentos idênticos a longo prazo, pois se de um lado é possível o aumento da composição orgânica do capital ao infinito; de outro lado, o aumento da taxa de mais valia encontra limites na impossibilidade de redução a zero do trabalho.

Não se pode esquecer ainda a atuação do movimento sindical a obstar o crescimento da taxa da mais valia; ii) redução do preço do capital constante, pois o incremento da produtividade se faz presente, também, nos setores de máquinas e equipamentos, o que redunda em diminuição do valor unitário e no aumento no número total de unidades. " $O$ incremento da composição orgânica do capital atua no sentido de uma redução dos preços das máquinas e, portanto, do valor do capital constante em relação ao capital variável contrarrestando, aí a queda tendencial da taxa de lucro"; iii) ampliação das fronteiras do modo de produção capitalista seja para outros países ou para outros setores dentro de um mesmo país, fazendo com que, em um primeiro momento, o comércio exterior fomente a troca entre nações desiguais no que tange ao nível de desenvolvimento capitalista, levando a diminuição do valor do capital constante e da própria força de trabalho e, por conseguinte, aumentando a da mais valia e do lucro. Esse movimento encontra limite quando o mundo todo estiver sob a égide do capitalismo; iv) aumento da massa de mais valia - o que significa dizer ganhar menos sobre um volume maior, fazendo com que este compense a diminuição daquele.

Esses fatores, no entanto, são insuficientes para se contrapor eternamente a essa lei, de forma que hão de ser empregues mecanismos outros, não para eliminá-la mas sim para mitigá-la, dentre eles, podem ser $\operatorname{citados}^{370}:$ i) crises de superprodução - como acima visto, elas criam condições favoráveis a um novo aumento da taxa media de lucro, ii) concorrência e centralização do capital, iii) desenvolvimento do capital improdutivo, iv) imperialismo, v) intervenções do Estado. De todos os fatores elencados, para os limites deste trabalho cabem duas derivações relevantes, uma delas diz respeito ao papel do Estado e a outra ao processo de "mundialização do capital".

Desde já é importante deixar claro que não se tratam de movimentos estanques ou independentes, conforme ficará evidente abaixo, mas, assim serão trabalhados apenas para fins didáticos e, também, não demais lembrar que essas medidas não significam a tábua de salvação para as eventuais crises do sistema, pois estas são ínsitas à equação capitalista de

capital constante en relación com el capital variable, contrarrestando así el descenso tendencial de la tasa de ganância”.

${ }^{370}$ Salama, Pierre; Valier, Jacques. Uma introdução à economia política...Op.Cit., p.110. 
produção e acumulação que leva ao desacoplamento entre produção e consumo, gerando o fenômeno da superprodução, seja ele de mercadorias ou de capitais. ${ }^{371}$

Antes mesmo de engendrar para as duas derivações propostas, cabe aqui um parêntese quanto à questão do desemprego intimamente relacionado à lógica até aqui descrita, cujos apontamentos servirão de base para as reflexões dos próximos itens. O desemprego ${ }^{372}$ é um elemento integrante do sistema que reflete a desarmonia entre a oferta e a demanda da força de trabalho, só que não no sentido keynesiano de disparate entre o gasto dos capitalistas e a geração de empregos ou no sentido liberal clássico da atuação da lei natural, tanto do crescimento da população como do desenvolvimento tecnológico.

Pelas duas pontas do desemprego, é possível verificar que: se do lado da oferta, não se pode fazer aqui um estudo aprofundado, razão pela qual suplantaria em muito os objetivos desta dissertação, mas é importante deixar consignada sua correlação a aspectos culturais e sociais e que conduzem, no limite, ao estado de derrelicção do homem no mundo. Pelo lado da demanda, foi exposto acima que a tendência imperativa do sistema é o aumento da produtividade do trabalho - mais valia absoluta para a mais valia relativa proporcionada pelo progresso técnico - como fator que altera a composição orgânica do capital, redundando na elevação de c (trabalho morto) em comparação ao v (trabalho vivo).

Não se pode creditar, no entanto, de per si ao progresso técnico a "causa natural" do desemprego mas sim deve vê-lo com relação ao imperativo da acumulação do capital. Isso porque a incorporação da tecnologia no processo produtivo por si só tem efeitos contraditórios: de um lado, gera emprego na medida que há um incremento do capital investido (aumento de $\mathrm{c}+\mathrm{v}$ ); de outro lado, ao ampliar a produtividade do trabalho - aumento da relação c/v - e, por conseguinte, reduz-se o número de empregos. "Sob um aspecto, a acumulação do capital, ao incorporar progresso técnico, destrói empregos; sob outro, cria$o s^{\text {”733 }}$, resultando dessa equação o número de empregos oferecidos. Mas, o que interessa ao desemprego é a correlação, ou melhor, o desacoplamento entre os crescimentos da produtividade e da acumulação, isso porque o aumento da produtividade conduz a uma diminuição do emprego, se e somente se a acumulação crescer de forma insuficiente. E, esta acumulação tem correlação direta com as ótimas condições capitalistas de produção mercados e lucros atrativos.

\footnotetext{
${ }^{371}$ Faleiros, Vicente de Paula. A política social do Estado capitalista...Op. Cit., p.66.

372 Salama, Pierre; Valier, Jacques. Uma introdução à economia política...Op.Cit., p.84/98.

${ }^{373}$ Salama, Pierre; Valier, Jacques. Ibid, p.87.
} 
Mais do que dissociar a ideia do desemprego de uma situação natural do sistema, não se pode deixar de consignar suas consequências sobre o conjunto da sociedade, pois o desemprego e sua imagem reflexa - insegurança no emprego - são também "formas de governar", seja na ponta dos capitalistas no que tange à formação e ou manutenção de um exército industrial de reserva; seja na ponta do operariado, a fomentar a divisão e a concorrência no interior da classe, arrefecendo, por exemplo, as políticas salariais, isso só para ficar em uma derivação imediata. Também aqui não se pode deixar de mencionar que o desemprego, sendo uma engrenagem do sistema tem limites delicados, pois seu excesso traduz-se em questões, tanto econômicas (consumo das mercadorias) como em questões políticas (a propalada questão social) a minar, eventualmente, a legitimidade do Estado.

\section{2) Intervenção do Estado na segunda metade do século $X X$}

Para a abordagem deste tópico não se pode esquecer que uma parte substancial do móbil da intervenção estatal tem a ver com a consolidação da burguesia como classe dominante e que a distinção entre os Estados liberal e social, tratada no capitulo I, é fundamentalmente uma diferença de sua atuação quantitativa e qualitativa do Estado. E mais, a base de sua intervenção está ligada, também, à disputa de classe que, ao ser incorporada pelo Estado em uma ambiência política favorável as classes trabalhadoras, redunda em leis sociais que, no limite, estão em linha com o regime capitalista de exploração e de acumulação. Essa é, em apertada síntese, a trajetória da social-democracia na segunda metade do século XX.

Não há espaço aqui para descrever todas as formas da intervenção estatal, de modo que serão arroladas algumas, sendo estas classificadas basicamente em duas categorias: direita e indireta ${ }^{374}$. Na primeira, o Estado transforma-se em verdadeiro empresário, toma par si os investimentos não rentáveis ao capital - aqueles não lucrativos, ou então, que exigem um

\footnotetext{
${ }^{374}$ Netto, José Paulo. Capitalismo monopolista e serviço social...Op.Cit., p.25/26.

Mandel discorrendo sobre a atuação do Estado na economia levanta dois pontos importantes, a saber: um deles é a chamada criação de "mercados adicionais", cujos exemplos históricos são o militar e o de obras públicas. E ao assumir as áreas de infra-estrutura e de serviços, o Estado passa a arcar com os custos indiretos da produção e da realização da mais valia, o que redunda na valorização do capital total, ou seja, o Estado passa a financiar a própria atividade privada. O outro diz respeito à subvenção que se dá, basicamente, de duas maneiras: a indireta por dois mecanismos: i) transferência da mais valia do setor público para o privado, cujos exemplos são os preços de energia, matéria-prima e de produtos semi-elaborados subvencionados pelo Estado; ii) tributação mais pesada sobre os salários, pois servem para compensar em parte a diminuição da lucratividade do setor público, ocorrida com a subvenção da cadeia produtiva. E a direta, via financiamentos direitos, investimento em pesquisa e tecnologia, etc... Mandel, Ernest. O capitalismo tardio. Trad. Carlos Eduardo S. Matos, Regis de Castro Andrade e Dinah de Abreu Azevedo. São Paulo: Abril Cultural, 1982, p. 386/389.
} 
dispêndio excessivo ou um tempo de maturação, para além das forças do capital - criando base para sua reprodução/acumulação, seja via grandes empreendimentos notadamente no setor de infraestrutura, gestão da moeda e do crédito ou ainda de benesses tributárias sob as mais diversas modalidades - subsídios, subvenções, isenções, etc.

Nessa linha, "o Estado cria as formas de tornar rentável os investimentos em políticas sociais - vide os exemplos da saúde e da previdência - seja pelo repasse à população desses investimentos ou pela consertação de formas de atendimento pelo setor privado. A intervenção não se limita à valorização de parcela do capital que não mais conseguiria se reproduzir na lógica de mercado, mas também na absorção do excedente por parte do Estado pela transferência de capacidade aquisitiva às pessoas ou pela compra de bens e serviços das empresas que leva a criação de procura efetiva." 375

Desse modo, a resultante final do processo é a expansão do capital para a esfera do público, o que leva à "transformação dos serviços sociais em mercadorias", após sua gestação no Estado, que amplia as áreas e as possibilidades de reprodução do capital e, por conseguinte, de lucro. Este último assunto dada sua relevância será retomado com maiores detalhes nos itens subseqüentes. Neste momento, objetiva-se apenas e tão somente pontuar a sua origem.

Quanto aos investimentos indiretos ${ }^{376}$, o Estado exerce um papel essencial na "formação - gestão - reprodução da força de trabalho", por toda uma série de tarefas básicas, como saúde, educação, transporte, ensino, moradia etc.. - que atendem pelo nome de "salário indireto" que enseja "a alta da produtividade da força de trabalho e o aumento da mais valia relativa". No que se refere a esta última, é um dos instrumentos pelo qual se vale o capital para se contrapor à "lei da baixa tendencial da taxa de lucro" em um duplo vetor: i) redução da utilização da mão de obra, ii) incremento de produção, bem como da produtividade. Operase pela ampliação da submissão da força de trabalho ao capital, seja pelos fatores de qualificação ou produtividade, pela nova forma da "divisão trabalho intelectual/trabalho manual", primado do "trabalho morto sobre o trabalho vivo", ou ainda, pelas inovações tecnológicas. Este conjunto de transformações tem por consequência a "submissão real do trabalho ao capital" englobando, desta forma, desde o instante da sua formação (âmbito escolar) até a rede de proteção social imbricada com o desemprego estrutural.

\footnotetext{
${ }^{375}$ Santos, Cleusa. A seguridade social e a esfera dos serviços. Universidade e Sociedade, Brasília, Ano XI, n'27, junho 02, p. 65.

${ }^{376}$ Poulantzas, Nicos. O Estado, o poder, o socialismo...Op. Cit., p.203/207.
} 
Em suma, o Estado atua "na redistribuição e na transferência da mais valia total entre as parcelas do capital, a contra-tendência principal e dominante à baixa tendencial da taxa de lucro reside, a longo-prazo, na alta, pelo Estado, da taxa da mais valia e da exploração". ${ }^{377}$ E a lógica da atuação do Estado como "contrarresultante da queda tendencial da taxa de lucro" informa, também, as políticas sociais voltadas à assunção dos "custos provocados pela desvalorização social do capital". ${ }^{378}$

O Estado enquanto instrumento a agir tanto na esfera social como na econômica assumiu um papel relevante para o desenvolvimento do capitalismo industrial, cujas consequências, além de não levar a superação da contradição essencial do sistema capitalista, ensejam outras variantes contraditórias, dentre as quais se destacam duas ${ }^{379}$ : a inflação e a crise do sistema monetário internacional, no final dos anos de 1960 e início dos anos de 1970, esta última a ser tratada no item subsequente dado que tem correlação com a "mundialização do capital".

No que tange à inflação, as despesas estatais caso fossem financiadas somente pela tributação concorreriam indiretamente com as vendas do setor privado, o que não levaria a um estímulo para a economia. A forma de estimulá-la é pelo aumento nominal do poder de compra - a ampliação dos meios de pagamento em circulação - o que gera uma tendência inflacionária, na medida que os investimentos estatais não ampliam a quantidade de mercadorias na mesma proporção em que aumentam os meios de pagamento. Ou seja, “ $a$ intervenção estatal feita para estimular uma expansão econômica (para superar ou limitar uma crise) tem levado metodicamente à inflação". ${ }^{380}$

Para além do déficit público, a inflação dita "permanente" deve ser entendida também como sendo a expressão na esfera da circulação das "duas contradições que, na esfera da produção, determinam a luta de classes e a concorrência intercapitalista no capitalismo contemporâneo" 381 e, por esse fato, é merecedor de uma análise mais detida.

A leitura corrente e tradicional do fenômeno inflacionário ${ }^{382}$ atrela-a aos custos salariais, pois a atuação sindical responsável em grande parte pelo aumento nominal dos salários acima da produtividade, ou seja, conclui-se que "a inflação rastejante é a manifestação de um poder excessivo dos trabalhadores".

\footnotetext{
${ }^{377}$ Poulantzas, Nicos. O Estado, o poder, o socialismo...Op. Cit., p.203.

${ }^{378}$ Santos, Cleusa. A seguridade social e a esfera dos serviços. Universidade e Sociedade...Op. Cit., p. 65.

${ }^{379}$ Salama, Pierre; Valier, Jacques. Uma introdução à economia política...Op.Cit., p.183.

${ }^{380}$ Mandel, Ernest. O capitalismo tardio...Op.Cit.,p.386.

${ }^{381}$ Salama, Pierre; Valier, Jacques. Uma introdução à economia política...Op.Cit., p.185.

${ }^{382}$ Salama, Pierre; Valier, Jacques. Ibid, p.183/193.
} 
Afirmam, também, que a política monetária é expansiva apenas para acompanhar as alterações de salário, de forma a permitir meios de liquidez necessários para financiar os aumentos de custo e preços, sendo ela uma consequência da inflação. A partir do diagnóstico das causas da inflação, a solução, apregoada e adotada posteriormente pelos diversos países para resolver esse problema, passa necessariamente por uma política dirigida contra os trabalhadores, quer seja restringindo os direitos sindicais como foi o caso dos EUA, ou então, sobre os próprios salários, como ocorrido na França.

No entanto, a chamada "inflação rastejante", caracterizada por um aumento permanente de preços, tem como fundamento as "novas formas assumidas no capitalismo contemporâneo tanto pela tendência a acumulação quanto pelas contradições que se verificam no processo desta acumulação" ${ }^{\text {,383 }}$. Nesse sentido, não se pode ignorar a atuação dos monopólios ${ }^{384}$ da formação de sua taxa de lucro, e a repercussão dessa ação na composição da inflação, pois aumentos nominais de salários são acompanhados por aumentos de preços com intuito de repor as margens de lucro sobretudo dos setores menos afetos à concorrência e, portanto, mais concentrados.

Para desenvolver melhor o argumento acima, é pertinente expor algumas características da dinâmica da formação de preços dos monopólios quando se compara com a uma economia de "livre concorrência". Dentre as especificidades dos monopólios, podem ser listadas: i) apropriação de superlucros, na medida que são capazes de obstar o ingresso de

\footnotetext{
${ }^{383}$ Salama, Pierre; Valier, Jacques. Uma introdução à economia política...Op.Cit., p.189.

384 Até aqui não foi feita qualquer menção acerca da formação dos monopólios, mas ela pode ser extraída do interior da lógica do capitalismo e também pelas políticas econômicas do Estado. Quanto à primeira, a evolução do sistema capitalista deixa transparecer que a própria concorrência leva a centralização e concentração dos capitais, haja vista que aquela fomenta a produtividade de trabalho as expensas da ampliação da composição orgânica do capital. Em apertada síntese, o que ocorre no âmbito da concorrência é o seguinte: Sem sair da clássica lei da oferta e da procura, numa dada situação em que a oferta de uma mercadoria suplanta a sua demanda, o seu preço de mercado cai. E ao cair, baixam os lucros de modo que os capitalistas tendem a se adaptar a nova realidade, via redução do preço de custo pela melhora da produtividade média do trabalho, fazendo com que empresas de baixa produtividade sejam expulsas do mercado, equilibrando novamente a oferta e a demanda. Esse movimento de redução de custos de produção acompanhado do aumento de produtividade conduz a uma elevação da composição orgânica do capital e faz com que o investimento e o progresso técnico sejam cada vez mais decisivos no âmbito da competição, traduzindo-se imediatamente numa elevação do tamanho médio da empresa, depois numa dificuldade cada vez maior de entrar nesse mercado novas empresas em virtude do tamanho de investimentos necessários para ali ingressar e, por fim, o processo de concentração continua agindo na medida em que agora as chamadas "pequenas empresas" não conseguem desovar suas mercadorias dado que seus custos de produção são mais elevados, o que finda com a sua retirada do mercado, fazendo com que cada vez mais algumas empresas que vão se agigantando nesse processo se apropriem de fatias cada vez maiores do mercado. Mandel, Ernest. Tratado de economia marxista...Op.cit.,p.149/151.

Quanto à atuação do Estado, seja pelo lado da política monetária como da sua atuação direta - investimentos e gastos públicos -, pelas reformas fiscais aliviando a tributação das empresas, estabelecimento de políticas de "grupo", fomentando a concentração do capital dando-lhe maior fôlego financeiro. Em suma, o Estado tem um papel significativo no que tange a fase de expansão e desenvolvimento do sistema, criando condições favoráveis à atuação dos monopólios quanto ao aumento de preços e dos lucros. Salama, Pierre; Valier, Jacques. Ibid, p. $181 / 182$ e $193 / 195$.
} 
novos concorrentes no setor, possibilitando a fixação de preços de modo mais duradouro, taxas de lucro superiores à média do mercado; ii) especificidade da concorrência entre os monopólios que levam a um aumento de custos específicos, seja pelas práticas de diferenciação dos produtos - leia-se publicidade, existência de capacidade produtiva ociosa, de uma taxa de acumulação elevada, redundando em encargos financeiros mais elevados e, em particular, dos custos de amortização; iii) a própria política de preços dos monopólios busca por aumento incessante na taxa de lucro - é um canal livre para a "transmissão da elevação de preços em todos os setores e em todas as empresas, provocando assim o aumento

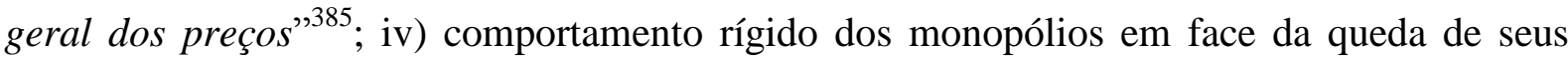
preços, dado que a concorrência nesse segmento é feita mais em torno da marca do que do preço em si; iv) os monopólios que em um primeiro momento parecem ir de encontro à lei do valor $^{386}$, acabam por referendá-la, na medida que "seus preços seguem os preços de produção, a uma velocidade que depende do caráter mais ou menos estável da posição que tem o

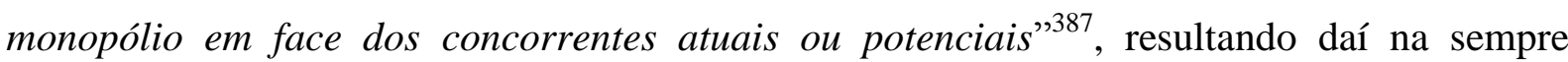
possível modificação dos grupos monopolísticos, alteração essa na dependência da correlação de forças presentes em um dado momento.

Os fatores acima arrolados contribuem para dar uma dimensão mais precisa do que realmente é constituído o mecanismo inflacionário e ajuda na compreensão da recente perplexidade quando o assunto é aumento de preços das commodities e inflação. Tanto na década de 1970 como agora nos anos $2000^{388}$, assistiu-se a um expressivo aumento de preços das matérias-primas; no entanto, o comportamento da inflação nos dois instantes foi diverso, qual a explicação para tal discrepância? Ao que tudo indica, a resposta para tal indagação passa pelo arrefecimento da luta de classes. Em 1970, a elevação dos preços das commodities e, do petróleo em particular, levou a uma espiral inflacionária nos países desenvolvidos, porquanto esse aumento reverberou nos seguidos reajustes dos salários nominais. Hoje, diante

\footnotetext{
${ }^{385}$ Salama, Pierre; Valier, Jacques. Uma introdução à economia política...Op.Cit., p.191.

${ }^{386}$ Mandel discorrendo acerca da economia do capitalismo tardio chega à conclusão que existem duas taxas de lucro - a dos setores monopolizados e a dos não monopolizados, e que ambas são governadas pela lei do valor, pois "o capital continua fluindo dos setores onde o lucro está abaixo da média para setores onde os lucros estão acima da média. O surgimento de duas taxas medias de lucro expressa ao mesmo tempo esse movimento único de equiparação e os obstáculos colocados à sua consumação pelas barreiras de entrada, que são sobretudo barreiras de escala (...) Na verdade, é exatamente a combinação do impulso permanente de equiparação da taxa de lucro com barreiras formidáveis colocadas pelos monopólios a essa equiparação que leva ao surgimento de duas taxas médias de lucro, uma ao lado da outra, durante um longo período de tempo, que só tendem a convergir a longo prazo." Mandel, Ernest. O capitalismo tardio...Op. Cit., p.383.

${ }^{387}$ Salama, Pierre; Valier, Jacques. Uma introdução à economia política...Op.Cit., p.192.

${ }^{388}$ Serrano, Franklin. A economia americana, o padrão dólar flexível e a expansão mundial nos anos 2000. In: Medeiros, Carlos Aguiar de; Da Costa, José Luís; Serrano, Franklin P. O mito do colapso do poder americano. Rio de Janeiro: Record, 2008, p. 145.
} 
da diminuição do poder de barganha dos trabalhadores, sobretudo dos países desenvolvidos, o que obsta reivindicações por aumento de salários nominais, a elevação dos preços das commodities não aponta para aumento vertiginoso dos números da inflação, tal como se deu no passado, "e nesse ambiente de baixa propensão à inflação, as empresas acabam percebendo corretamente a maior parte das grandes flutuações de curto prazo do preço das matérias-primas, alimentos e petróleo como temporárias, e rapidamente reversíveis. E mesmo os aumentos permanentes de custos têm sido facilmente absorvidos por perdas nos salários reais". ${ }^{389}$

\section{3) Crise de 2008 e seus antecedentes remotos}

Retomando o fio condutor da contradição do sistema capitalista, após um período de arrefecimento e de controle relativo sob a tutela da intervenção estatal, a conhecida e teorizada contradição se fez presente novamente com o chamado "fim dos anos dourados" ou da "crise do padrão fordista". Esse período foi marcado pela conjugação do fortalecimento dos capitais privados (industrial e bancário) ocorrido no período, dos crescentes impasses das políticas do Welfare, redundando em aumento de tributos, déficits e inflação, e no esgotamento do modelo fordista de reprodução de capitais, dando ensejo a que uma massa deles buscasse outras formas de valorização, e, sob esse quadro, a financeirização ${ }^{390}$ daria seus passos.

O relevante para compreendê-la como característica central do processo de mundialização do capital a marcar sua nova fase de acumulação, diferente de qualquer noção pretérita de internacionalização desse mesmo capital, reside na articulação de dois flancos fundamentais: econômico e político, uma vez que a acumulação rentista, ou melhor, o ciclo encurtado do capital dinheiro ou do capital fictício "reflete mudanças qualitativas nas relações de força política entre o capital e o trabalho, assim como entre o capital e o Estado, em sua forma de Estado de Bem-Estar, ${ }^{391}$.

Se, no lado da economia, o dado relevante foi o impasse do modelo fordista de acumulação e reprodução representado por uma crise de superprodução, ainda em meados da

\footnotetext{
389 Serrano, Franklin. A economia americana, o padrão dólar flexível e a expansão mundial nos anos 2000. In: Medeiros, Carlos Aguiar de; Da Costa, José Luís; Serrano, Franklin P. O mito do colapso...Op. Cit., p.134.

${ }^{390}$ Chesnais, François. Introdução geral. (In) Chesnais, François (org.). A mundialização financeira. Gênese, custos e riscos. Trad. Carmem C. Cacciacarro, Luis Leiria, Silvana Foá e Valéria C. da Paz. São Paulo: Xamã editora, 1998, p. 16.

${ }^{391}$ Alves, Giovanni. Trabalho e mundialização do capital. A nova degradação do trabalho na era da

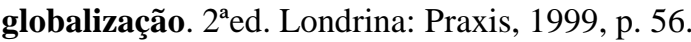


década de 1960, acompanhada da queda da taxa de lucro da indústria, da baixa rentabilidade dos investimentos industriais, levando esses ativos a procurarem novas vias de valorização, agora sob a forma financeira; o lado da política, nos anos de 1970 e 1980, fomentou de modo decisivo a mundialização do capital, via processos de liberalização e de desregulamentação financeira perpetrados pelos Estados, mais especificamente, Grã-Bretanha e EUA, sob a batuta de Thatcher e de Reagan na assim conhecida "revolução conservadora".

Essa revolução fora, em parte, antecipada pela política adotada pelo FED, no final dos anos de 1970, de juros altos e dólar valorizado a fim de possibilitar "a titularização ou mercadorização" da dívida pública, como forma de alento para o financiamento dos déficits sem excessivo sofrimento político, dando, ainda, seja por acaso ou coincidência, a oportunidade para que os fundos de pensão privados oriundos do sistema fordista encontrassem nesses títulos um meio de valorização. Assim, "a partir de meados da década de 1980 constata-se um processo de crescimento das instituições financeiras baseado na transferência para elas, de uma fração significativa da renda nacional de quase todos os países da OCDE (20-25\% dos gastos orçamentários e 3-5\% do PIB conforme os países)"392.

E mais, o avanço da revolução conservadora com sua política neoliberal de fé inabalável no mercado como forma de solucionar a crise do capitalismo nos anos de 1970 vai pôr na berlinda a Social-Democracia e sua quimera com relação à possibilidade de regular o capital nos estritos limites dos Estados Nacionais. É, também, a partir desse instante que as ideologias da globalização e do progresso técnico a informarem o processo de reestruturação produtiva, objetivando a valorização do capital iriam se contrapor às estruturas fordistas e, mais precisamente, aos sindicatos. Ou seja, "é na virada da década de 70 para 80, no bojo da ofensiva do capital na produção (a reestruturação produtiva) e da ofensiva do capital na política (o neoliberalismo) que se dá o ponto de partida para a mundialização do capital." 393

É imprescindível ressaltar, desde já, que essa mundialização, abaixo descrita em suas fases mais importantes, é processada na base da hipertrofia da esfera financeira engendrada em uma autonomia que é real e relativa, na medida que "a esfera financeira nutre-se da riqueza criada pelo investimento e mobilização de uma força de trabalho de múltiplas qualificações. Uma parte, hoje elevada, dessa riqueza é captada ou canalizada em proveito da esfera financeira, e transferida para esta. Somente depois de ocorrer essa transferência é que podem ter lugar, dentro do circuito fechado da esfera financeira, vários processos de

\footnotetext{
${ }^{392}$ Alves, Giovanni. Trabalho e mundialização do capital...Op. Cit.,p.72.

${ }^{393}$ Alves, Giovanni. Ibid, p.59.
} 
valorização, em boa parte fictícios, que inflam ainda mais o montante nominal dos ativos financeiros." 394

O dado distintivo desse novo período de acumulação capitalista quando comparado com os períodos pretéritos é, sem dúvida, a maximização dessa capacidade, pois "a retenção sobre a mais-valia tem a forma imediata de uma punção sobre os lucros industriais. Mas as empresas, principalmente as grandes, têm meios de transferir o peso de punção sobre os assalariados". ${ }^{395}$ Ou seja, não se pode perder a dimensão da esfera produtiva mesmo quando o primado é claramente da financeira, seja porque a origem desta é diretamente imbricada com aquela; ou, ainda, porque a própria acumulação fordista ratificou a tendência à saturação dos mercados criando um "estado endêmico de superprodução. Deste modo, a massa de capital-dinheiro valorizando-se dentro da esfera financeira provém dos sucessos (e insucessos) do capital produtivo". 396

Tecidas estas considerações, pode-se caminhar para a descrição linear do processo de mundialização das finanças, com base nas ideias Chesnais, em três instantes ${ }^{397}$, a saber: o regime de cambio flexível pós-derrocada do sistema de Bretton Woods; a securitização da divida pública dos países industrializados dos quais os Estados Unidos foram o exemplo mais vistoso; por fim, a interligação entre os mercados acionários e o ingresso dos emergentes. Esta descrição objetiva dar os elementos necessários, organizando-os a fim de adentrar na fase final do item em tela - o entendimento da crise, bem como das suas repercussões sobre os direitos sociais, haja vista que passado mais de ano do seu início, seus reflexos sobre o social mostram-se ainda muito contraditórios.

A respeito da primeira fase da mundialização - mercado de câmbio -, há de se destacar dois pontos: formação e desenvolvimento do mercado de eurodólares e o fim dos acordos de Bretton Woods. Ainda na década de 1960, verificou-se o surgimento do mercado de eurodólares que era um mercado interbancário, atuando em paralelo aos sistemas financeiros nacionais com a concordância dos próprios governos que se valiam desse mercado como fonte suplementar de liquidez. Ainda no final daquela década, assistiu-se ao ressurgimento das finanças especulativas em alguma medida em prol do mercado de eurodólares informado pelo retorno dos "ataques às moedas" - libra e dólar - que serviram de

\footnotetext{
${ }^{394}$ Chesnais, François. A mundialização do capital. Trad. Silvana F. Foá. São Paulo: Xamã editora, 1996, p. 246.

${ }^{395}$ Chesnais, François. Ibid, p.247.

396 Alves, Giovanni. Trabalho e mundialização do capital...Op. Cit.,p.73.

${ }^{397}$ Chesnais, François. Introdução geral. (In) A mundialização financeira...Op. Cit., p. 16.
} 
prenúncio do ocaso do câmbio fixo. Esses dados em seu conjunto significaram alguns dos sintomas do recrudescimento das contradições do sistema.

O passo determinante deste mercado privado de endividamento foi tomar como clientes os países do terceiro mundo e, em seguida, espraiar-se para o mundo como um todo. A partir da associação de capitais fordistas ávidos por lucros e de medidas de desregulamentação das políticas monetárias vigentes por parte de alguns Estados (preponderantemente EUA e Reino Unido), esse mercado interbancário pode consolidar-se na esteira da "milagrosa multiplicação de crédito". O mecanismo baseado na moeda escritural, sem mecanismos de controle ou de reserva obrigatória, foi à forma de empréstimo, por excelência, até 1982, dos bancos internacionais aos países do terceiro mundo.

O dado central desse mercado é a existência de um multiplicador de criação de crédito que obsta "transferência real" de poupança do credor para o devedor, ao reverso esse sistema, favorável ao credor, produziu "o reerguimento da economia dos países da OCDE, mediante as exportações ao terceiro mundo, os convidativos créditos oferecidos criaram investimento, emprego e renda" ${ }^{, 398}$.

Já para os países tomadores de empréstimo, esses créditos tinham natureza de capitais enquanto que para os bancos internacionais esses créditos tinham como resultante final o ingresso de lucros. Tanto isso é verdade que a crise da divida desses países nos anos de 1980 e sua consequente insolvência tiveram como resultado uma diminuição dos lucros bancários sem afetar a solvabilidade destes últimos. Assim, o reescalonamento dessas dívidas deu-se, posteriormente, com a dolarização das economias devedoras, "bem como a colocação à venda de setores inteiros da economia, como na Argentina, são conseqüências diretas do endividamento e dos meios empregados para garantir o pagamento dos juros"399.

No tocante ao sistema de Bretton Woods, findou, em agosto de 1971, em razão do duplo déficit americano - comercial e orçamentário, que impossibilitava a manutenção da paridade dólar-ouro em virtude das necessidades de criação de meios monetários por aquele país para financiar a emissão de títulos públicos. Esse sistema, em grandes linhas, surgiu como substituto do antigo padrão ouro como moeda internacional vigente até 1914. A experiência histórica posterior à $1^{\mathrm{a}} \mathrm{GG}$, seguida da crise do entre guerras até a $2^{\mathrm{a}} \mathrm{GG}$ mostrou na premência da necessidade de existir um equivalente geral como meio de referência e de pagamento internacional de modo que coube ao dólar ao lado do ouro conversível por uma taxa fixa fazer "às vezes" da moeda internacional.

\footnotetext{
${ }^{398}$ Chesnais, François. A mundialização do capital...Op. Cit., p.256.

${ }^{399}$ Chesnais, François. Ibid, p.257.
} 
A razão dessa posição de destaque do dólar deu-se em função da posição americana no cenário internacional. O sistema de cambio fixo (dólar atrelado ao ouro) permitia uma certa estabilidade do sistema financeiro e monetário internacional, bem como possibilitava um relativo controle do crédito, das instituições financeiras e do capital às necessidades da produção.

Sua revogação deu início ao chamado sistema de "taxas de cambio flexíveis", permitindo a financeirização do mercado de câmbio e servindo de via para que os ativos financeiros buscassem novas formas de valorização, só que agora com liquidez máxima.

A segunda fase pode ser datada a partir “das decisões tomadas em 1979-1981, após a nomeação de Paul Volker para o Federal Reserve e da ascensão de Margaret Thatcher ao poder." ${ }^{400}$ Duas medidas foram relevantes: a primeira diz respeito ao fim do mecanismo de controle de capitais com o exterior, liberalizando seu ingresso e saída; a outra, refere-se ao início do movimento de desregulamentação monetária e financeira, culminando nesse período com a expansão do mercado de bônus interligados internacionalmente.

O mercado de bônus do tesouro e outros títulos da divida vai ao encontro das necessidades tanto dos Estados Nacionais (países da OCDE) como dos grupos que centralizam fatias relevantes da poupança acumulada na esfera produtiva. Pelo mecanismo de taxa de juros reais positivas associada às elevações na taxa de câmbio (mais precisamente o dólar) conseguiu-se financiar o déficit orçamentário dos Estados e outorgar ao investidor/credor o poder de dispor sobre a remuneração desses títulos - taxas de juros a longo prazo.

Assim, o mecanismo de securitização da dívida pública "provocou a explosão da divida federal americana, cujo montante cresceu nos anos 80 de forma ainda mais rápida que nas décadas anteriores" ${ }^{401}$, fazendo desse mercado de títulos públicos a "espinha dorsal” do sistema financeiro internacional, "lugar onde foram parar cerca de $30 \%$ dos ativos financeiros mundiais em busca de rendimentos estáveis e líquidos"402.

Esse movimento de financiamento dos déficits públicos americano e britânico foi seguido por outros países desenvolvidos a ponto de haver ainda, na primeira metade da década de 1980, uma clara mudança da trajetória dos capitais que abandonaram a era dos empréstimos conjuntos voltados para os países do Terceiro Mundo e que se voltaram para o

\footnotetext{
${ }^{400}$ Chesnais, François. Introdução geral. (In) A mundialização financeira...Op. Cit., p. 25.

${ }^{401}$ Chesnais, François. Ibid, p. 26.

${ }^{402}$ Chesnais, François. Ibid, p. 27/28.
} 
processo de "mercadorização dos financiamentos", que sobressaem a aplicação de bônus do tesouro e outros ativos da divida nos mercados financeiros.

O novo regime de acumulação sob o primado da financeirização da dívida pública dos países desenvolvidos teve como consequência mais visível a aparição de atores novos no cenário internacional de modo que os fundos de pensão e as sociedades de investimento coletivo (mutual funds e organismos de aplicações coletivas em valores mobiliários), os maiores beneficiados, pudessem em curto espaço de tempo suplantar até mesmo os maiores bancos nesses mercados.

Ressalte-se que os fundos de pensão são gestados na esfera produtiva como forma de angariar poupança dos trabalhadores para que estes no futuro se beneficiassem por meio de pensões, ou seja, sua origem é salarial. No entanto, a busca pela máxima rentabilidade com preservação da liquidez proporcionada pelo processo de financeirização transformou esses fundos enquanto "expressões de poupanças modestas" em "instituições centrais do capital financeiro" e a ditar as finanças especulativas.

Nesse processo de mundialização do capital, há uma terceira fase bem demarcada, iniciada nos anos de 1990 com a interligação dos mercados acionários, estes se forem comparados com os dois anteriores (o de câmbio e o de bônus) são incipientes no que tange à sua integração, isto pode ser visto pelas oscilações dos índices de Nova York que se espraiam para outras praças mundiais, mas que não dizem respeito tanto à interligação direta desse mercado "e sim, mais, o mimetismo das relações dos investidores. Esse contágio de uma praça financeira a outra expressa a reposta extremamente nervosa dos detentores de títulos, pois são bem conhecidos, quando não o seu caráter fictício, pelo menos os níveis totalmente irreais de capitalização, anunciando crashes de maior ou menor gravidade". 403

Outro dado significativo dessa fase é a integração dos países emergentes (Ásia e America Latina) no processo de financeirização constituído, em grandes linhas, pela securitização das suas dívidas públicas e formação de mercado de bônus nacionais interligados aos mercados financeiros dos países desenvolvidos.

Observou-se, ainda, a consolidação do mercado de derivativos. Esse mercado, na origem, dizia respeito ao reaproveitamento de ativos duvidosos ofertados a taxas variáveis pelos bancos oriundos dos créditos concedidos aos países do terceiro mundo na década de 1970. Hoje, ele engloba todo e qualquer tipo de crédito a taxas diversas configurando assim as chamadas "operações de risco", dentre elas, incluem-se os derivativos - "créditos que já

${ }^{403}$ Chesnais, François. Introdução geral. (In) A mundialização financeira...Op. Cit., p. 30. 
encontraram comprador, mas que seus detentores vendem por antecipação (a chamada operação a termo) no mercado secundário, que hoje é o dobro do primeiro (o "verdadeiro") a quase todos os títulos e efeitos." ${ }^{404}$ Nesse instante, a menção aos derivativos objetiva apenas pontuá-los no bojo do processo, uma vez que suas consequências serão abaixo analisadas quando dos apontamentos sobre a crise de 2008.

O capital produtivo não ficou incólume às mudanças do padrão capitalista de acumulação de onde se depreende um imbricamento sem precedentes dos grandes grupos industriais com as operações financeiras. De um lado, verificaram-se alterações profundas e definitivas na forma organizacional das empresas - toyotismo - a partir da crescente importância dos investimentos externos diretos (IED) em detrimento da simples troca, no aumento dos fluxos de trocas intrafirmas, nas novas modalidades de acordo interempresas no tocante a transferência de tecnologia, bem como nas fusões e aquisições transnacionais.

Essas modificações na morfologia do capital industrial derem ensejo ao nascimento da holding, verdadeiro "sistema nervoso de um conjunto mais extenso de atividades, interdependentes porém administradas de maneira menos formal (...) cuja tarefa primeira consiste em possibilitar a progressão da estratégia concorrencial global e da posição da organização que está em seu núcleo" ${ }^{\text {"405. }}$.

De outro lado, o poder financeiro da holding, quer seja no viés de investidor, ou ainda, de colocação de suas obrigações sem intermediário financeiros nos mercados, é a expressão maior da importância da financeirização na seara produtiva de forma que hoje reina a "confusão das fronteiras entre o lucro e a renda na formação do lucro de exploração dos grupos" $" 406$.

Por fim, essa fase é marcada também por inúmeros choques e sobressaltos, cuja lista tem início no crash das bolsas em 1987, segue por uma primeira bolha especulativa nos EUA em 1991, passando por especulações sobre as moedas européias (SME), em 1992; crises do México, em 1995; Tigres Asiáticos, em 1997; Rússia, em 1998; Brasil, em 1999; Argentina, em 2001, a dar uma amostra "do modo de funcionamento do sistema mundializado de finanças diretas, em que as instituições principais são os mercados e as bolhas especulativas são parte integrante da vida econômica"407.

\section{4) Crise de 2008 propriamente dita}

\footnotetext{
${ }^{404}$ Chesnais, François. A mundialização do capital...Op. Cit., p.267.

405 Alves, Giovanni. Trabalho e mundialização do capital...Op. Cit.,p.74/75.

${ }^{406}$ Alves, Giovanni. Ibid, p.76.

${ }^{407}$ Chesnais, François. Introdução geral. (In) A mundialização financeira...Op. cit., p.31
} 
Após ter realizado o inventário das fases da mundialização, pode-se agora avançar sobre a crise iniciada, em 2008, tendo por pano de fundo o novo desenho assumido pela economia mundial, a partir da virada do século XXI, enquanto "totalidade diferenciada e hierarquizada, cujos pólos são os EUA e a China". Em torno desses dois países, pauta-se o artigo de Chesnais intitulado - Até onde irá à crise financeira ${ }^{408}$ - feita a partir do diálogo com os trabalhos de Jorion e Aglietta/Berrebi.

O primeiro voltado ao estudo do mercado hipotecário americano, o segundo dirigido à relação entre a fase atual de acumulação do capitalismo e as possibilidades de recorrência das crises financeiras, na medida que, excetuando as fases de difusão da tecnologia, o primado do capital rentista sobrecarrega o capital produtivo, dado que os interesses dos acionistas hoje ter mais poder de força do que os interesses próprios das empresas.

Nesse sentido, a leitura de Chesnais pauta-se pela interconexão entre as crises de superprodução e as crises financeiras. Segundo o autor, esse fenômeno já se fez presente na crise asiática do final dos anos de 1990, notadamente, uma crise de superprodução, cujos desdobramentos puderam ser sentidos no setor financeiro, mais especificamente com o estouro da bolha da Nasdaq, em 2001. Ali, o FED atuou em dois vieses: em um deles, dando liquidez ao mercado, visando salvaguardar os fundos; no outro, ampliando o crédito hipotecário. A crise atual segue a mesma lógica com uma peculiaridade, qual seja: inverte-se a origem - do financeiro para a produção, “cuja lenta gestação na Ásia aparece em muitos índices".

Com objetivo de melhor correlacionar as crises nas duas esferas, Chesnais parte para a análise do crédito imobiliário americano e do chamado "fator China" asseverando que a crise financeira contida com relativo sucesso em um curto espaço de tempo deve se desdobrar numa desaceleração da economia global, na medida que o arrefecimento da demanda americana fará sentir-se na China em virtude do imbricamento hoje existente entre as duas economias. Assim, a China ao sair à procura de mercados a fim de suprir o americano, poderá se deparar com os efeitos da superprodução e na sua bem conhecida conseqüência: crise do sistema capitalista.

No que tange ao crédito imobiliário, Chesnais parte da seguinte constatação: esse mercado foi o grande responsável por mitigar e, até mesmo, afastar a crise dos EUA. Em um ambiente em que o crescimento da massa salarial não é expressivo e os rendimentos dos capitais rentistas, limitado a alguns poucos, não conseguem manter a atividade econômica

\footnotetext{
${ }^{408}$ Disponível em: http://duplo.uol.com.br/2007-11a1993. Acessado em 29/08/09.
} 
aquecida por muito tempo e, também, os países emergentes não conseguem suprir essa deficiência em virtude de suas peculiaridades, tais como um insipiente mercado interno, uma desigualdade social tremenda, os excedentes comerciais voltados a financiar os déficits americanos; a pergunta imediata que se apresenta é como possibilitar o crescimento sustentável a demanda? A resposta para este paradoxo reside na "expansão do crédito. É aí que o capitalismo contemporâneo encontra a demanda que permite realizar as exigências do valor acionário. Esse mecanismo atinge seu paradoxo nos Estados Unidos (...) Empurrando para o alto os preços dos ativos patrimoniais, o crédito desconecta o consumo da renda disponível."

Nessa linha, Chesnais constata que a maior fonte de lucros nos EUA, representando $60 \%$, advém da compra e revenda de imóveis enquanto que a bolsa de valores, em segundo lugar, representa 20\%. Logo, é bem compreensível o porquê do FED, no inicio do século XXI, ter elegido o mercado de imóveis para contrarrestar a crise pelo aumento do consumo das famílias.

O crescimento do consumo financiado pelo crédito tem correlação direta com a evolução da taxa de juros e com as condições em que esse crédito é oferecido. "A parte da riqueza que tem importância na evolução do consumo e da demanda agregada em geral é a riqueza imobiliária, pois a valorização dos preços dos imóveis estimula tanto o crescimento especulativo do investimento residencial quanto permite, por meio do refinanciamento de hipotecas já existentes, a realização de ganhos de capital elou a obtenção de crédito para consumo, onde o colateral é o próprio imóvel hipotecado." ${ }^{409}$

Ao buscar a origem do mercado hipotecário americano, Chesnais apoiado nos estudos de Jorian que inventaria esse mercado, conclui que sua base fôra desde sempre (anos de 1910) o recurso à securitização, via mercado secundário, a fim de legitimar o capitalismo americano a partir da ideia de sociedade de proprietários (ownerships society). Esse recurso se fez presente em diversos momentos da história americana, para citar alguns - 1938, 1970 e 2001 -, só que o dado distintivo do último é uma desregulamentação financeira sem precedentes iniciada no final dos anos de 1970, somado a uma taxa de juros muito baixa.

A combinação desregulamentação e baixa taxa de juros deu ensejo à formação de uma bolha imobiliária pelo crescimento do mercado de subprime - "clientes de baixa renda, sem garantias e com históricos de créditos problemáticos. Evidentemente, este processo não iria muito longe se estes títulos não pudessem ser vendidos com facilidade e, para isto, estes

\footnotetext{
${ }^{409}$ Serrano, Franklin. A economia americana, o padrão dólar flexível e a expansão mundial nos anos 2000. In: Medeiros, Carlos Aguiar de; Da Costa, José Luís; Serrano, Franklin P. O mito do colapso...Op. Cit., p.102.
} 
foram empacotados em vários e complexos instrumentos financeiros, que combinavam frações de empréstimo imobiliários de alto risco com outros ativos melhores". E com a garantia informal e implícita de recompra pelos bancos originadores desses títulos em caso de dificuldade no mercado, garantiu-se, assim, uma demanda por esses títulos entre os mais variados atores - fundos de pensão, fundações, governos, outros bancos, etc...

Em um primeiro momento de valorização crescente dos imóveis, a bolha era alimentada não só porque a dívida era rolada na medida que os empréstimos eram refeitos em patamares de preço mais elevados para os imóveis adquiridos, como também o tomador do empréstimo valia-se desse aumento sob a forma de ganho de capital que financiava seu consumo.

Esta tendência começou a se inverter, a partir de 2004, quando o FED iniciou o aumento continuo das taxas básicas de juros, levando à desaceleração do mercado imobiliário com a queda dos preços dos imóveis e aumento da inadimplência sentida no final de 2006. Nos anos seguintes, dada a retração do mercado e, até mesmo, a desconfiança quanto à solidez das instituições financeiras, o FED viu-se obrigado a baixar rapidamente a taxa de juros e a prover liquidez ao mercado, como forma de evitar falências em massa e paralisação do sistema de crédito.

Para além de saber os motivos que levaram o FED a fazer sucessivos aumentos na taxa básica de juros americana ${ }^{410}$, ao que tudo indica foi de não acostumar o mercado com juros de curto e de longo prazo baixos. O essencial é extrair que o crescimento sustentado da economia americana não se coaduna com o regime de juros altos e alto grau de endividamento das famílias em um ambiente de crescimento pífio da massa salarial.

Questão adjacente ao mercado imobiliário americano na análise de Chesnais é o assim chamado "fator China". O ingresso definitivo da Ásia no capitalismo tem como consequência imediata o aumento da competição entre os trabalhadores "em razão da duplicidade da oferta de trabalho global, como o excesso estrutural de mão de obra que ela cria no seio de uma economia mundial liberalizada e desregulamentada”.

Essa competição é seguida do empobrecimento dos assalariados e acompanhada pelo regime de "inclinação deflacionista", pois "a transferência para os assalariados das pressões deflacionistas sofridas pelas empresas se fez acompanhar, na esfera financeira, de uma baixa das taxas de juros a longo prazo e de uma modificação do movimento de longa duração das

\footnotetext{
${ }^{410}$ Serrano, Franklin. A economia americana, o padrão dólar flexível e a expansão mundial nos anos 2000. In: Medeiros, Carlos Aguiar de; Da Costa, José Luís; Serrano, Franklin P. O mito do colapso...Op. Cit., p.106/110.
} 
ações" o que leva os fundos de investimento, invariavelmente, a buscarem aplicações cada vez mais arriscadas a fim de sorver sua necessidade por acumulação.

Em linha com o exposto até aqui, Serrano apresenta seu esquema de análise cujo fundamental está no fato de que "praticamente a totalidade dos passivos externos americanos é denominada em dólares e praticamente todas as importações de bens e serviços dos Estados Unidos são pagas exclusivamente em dólar. Só este fato gera uma enorme assimetria entre o ajuste externo dos Estados Unidos e dos demais países (...)"411.

A razão de ser desta assimetria reside, segundo o autor, no padrão dólar flexível que tem o condão não só de tornar os EUA no "mercado financeiro do mundo", como ainda o torna o "banco central do mundo", na medida que emitem a moeda internacional; e, mais, faz com que os passivos externos financeiros, todos nominados em dólar, acompanhem as taxas de juros determinadas pelo FED, "configurando um caso único em que um país devedor determina a taxa de juros de sua própria divida externa." Desse ponto central, o autor apresenta três derivações importantes ${ }^{412}$, a saber: i) a primeira é de que o crescimento das economias capitalistas bem como do investimento, diferentemente da tendência clássica da oferta de poupança, é pautada pela “expansão sustentada do mercado final - gastos e consumo, gastos públicos, exportações e investimento residencial”; ii) a questão da inflação, já abordada acima, tem haver com os custos de produção que, em última análise, derivam do desenvolvimento da tecnologia e das "variáveis distributivas (salários, impostos indiretos e rendas de diversos tipos)", apresentando as últimas um componente político e institucional muito significativo. Essa ótica afasta-se, novamente, da corrente dominante que analisa a inflação e variável preço relativo (nacional ou internacional) enquanto "índice de escassez", seja dos produtos ou dos fatores de produção; iii) por fim, o autor apõe o primado no Estado e não no mercado, pois é o Banco Central quem determina a taxa de juros de curto prazo e esta tem o condão de influenciar a de longo prazo. Muito embora a taxa de longo prazo é fixada pelo mercado, na verdade, ela tem por norte "o curso futuro das taxas curtas fixadas pela autoridade monetária, o que implica que o Banco Central tem o poder de influenciá-las decisivamente". Com base nesse arcabouço teórico apresentado em apertada síntese, Serrano conclui, em linha com esta dissertação, que a questão da crise não envolve tanto o padrão dólar flexível, ou seja, não se trata de uma crise monetária mas sim é uma crise financeira cuja

\footnotetext{
${ }^{411}$ Serrano, Franklin. A economia americana, o padrão dólar flexível e a expansão mundial nos anos 2000. In: Medeiros, Carlos Aguiar de; Da Costa, José Luís; Serrano, Franklin P. O mito do colapso...Op. Cit., p.76.

${ }^{412}$ Serrano, Franklin. Ibid, p.76/77.
} 
origem tem a ver com o excesso de desregulamentação e falta de controle dos mercados privados.

Por último, uma análise interessante da crise é aquela entabulada por José Luís Fiori $^{413}$ que merece por sua aguçada percepção ser aqui ser menciona. $\mathrm{O}$ autor mostra todo seu ceticismo quanto às eventuais perspectivas, mudanças de rumo, etc.. que pudessem advir dessa crise, uma vez que se assiste hoje "uma versão invertida da famosa frase de Thatcher: there is no alternative", com o agravante de que paira no ar e em todos os meios uma apatia política, diferente do ambiente em que se instalou a onda conservadora dos anos de 1980 e 1990.

Nesse contexto, o autor traça um panorama das diversas correntes desde os liberais até os marxistas que estudam a recente crise, afirmando que: os liberais retiraram-se do front, seu discurso limita-se à esfera moral (contra os "vicios privados e excessos públicos"), e refugiaram-se na retaguarda e ali defendem ferrenhamente seus propósitos antiestatizantes. Já os keynesianos, pautados nos ensinamentos de Minsky quanto à tendência endógena das economias monetárias à instabilidade financeira, explicam apenas a origem imediata da crise, mas suas análises são insuficientes para entender seus desdobramentos, na medida que ficam na superfície do "erro liberal invertido" - se os liberais têm uma fé inabalável no mercado; os keynesianos, a seu turno, são depositários da esperança do "Estado corretor".

As duas concepções, no entanto, vislumbram o "Estado homogêneo e externo ao mundo econômico", seja na versão de "guarda- florestal" dos liberais ou na versão "Papai Noel" dos keynesianos. Ambas as análises não colhem o fundamental: a centralidade do processo de desregulamentação dos mercados da qual se extrai não só a financeirização do sistema capitalista e o enriquecimento privado como também o fortalecimento do Estado norte-americano.

Quanto aos marxistas, José Luís Fiori afirma que não há uma tendência definida para interpretar a crise, variando dentro de um amplo espectro: uns na linha keynesiana; outros na linha clássica das crises (sobreprodução, subconsumo e da tendência ao declínio da taxa de lucro); outros em uma espécie de "esquerda pós-moderna", angariando as linhas anteriores e acrescendo fatores outros como questões ambientais, energéticas, alimentares, etc...; e, ainda, existem os neo-marxistas que, em linhas gerais, trabalham a história como sucessões de ciclos hegemônicos, nas quais as crises transcendem a esfera econômica e insurgem-se nas relações

\footnotetext{
${ }^{413}$ Os economistas e a crise. Disponívelem:http://www.ip.urfj.br/aparte/pdfs/os_economistas_e_a_crise_fiori.pdf. Acessado em 30/08/09.
} 
globais de poder e, desse modo, estar-se-ia hoje diante da crise hegemônica dos EUA, bem como sua migração para outro centro - China.

Dentro dessa miríade de possibilidades teóricas, José Luis Fiori apresenta sua leitura desenvolvida a partir da "teoria do universo em expansão e a tese da explosão expansiva" "414. Em apertada síntese, ele afirma que o sistema mundial é parte de um universo em expansão contínua desde "o longo século XIII", com quatro momentos importantes referentes às explosões expansivas no interior do próprio sistema. Esses momentos (1150/1350, 1450/1650, 1790/1914, 1970/___ são indicativos do alargamento e ampliação das fronteiras do universo preexistente ocorrida em virtude do aumento da "pressão competitiva", que reflete as disputas e os conflitos entre "potências" líderes.

Assim, o sistema mundial enquanto universo em expansão abriga todos os Estados a disputar o poder global, mais especificamente, sua hegemonia e liderança, instituindo sempre "ordem, desordem, expansão e crise, paz e guerra. Por isso, crises econômicas e guerras não são, necessariamente, um anúncio do fim ou do colapso dos Estados e das economias envolvidas. Pelo contrário, podem ser uma parte essencial e necessária da acumulação do poder e da riqueza desses Estados, e do próprio sistema mundial. E nessa conjuntura, em particular, as crises e as guerras que estão em curso fazem parte - do nosso ponto de vistade uma transformação estrutural, de longo prazo, que começou na década de 1970 e que aponta, neste momento, para um aumento da pressão competitiva mundial - geopolítica e econômica - e para o início de uma nova corrida imperialista entre as grandes potenciais, que já faz parte de mais uma explosão expansiva do sistema mundial, que se prolongará pelas próximas décadas e contará com uma participação decisiva do poder americano". ${ }^{415}$

É importante deixar consignado que o autor, diferente dos neo-marxistas, não trabalha com a ideia de sucessão entre nações mas sim de fusão de onde derivam blocos político-econômicos cada vez mais poderosos, citando como exemplo o "alargamento do poder anglo saxão”, originado na Holanda, passando pela Grã Bretanha e chegando aos EUA. Esse é, em apertada síntese, o pano de fundo do arcabouço teórico de Fiori da qual deriva sua visão bastante peculiar sobre a atual crise.

Hoje, a análise da crise tem de necessariamente partir da crise dos anos 1970, não como crise do poder americano ou fim do império americano. Ela precisa ser ponderada como uma resposta dos EUA àquela crise cujas consequências se fizeram sentir nas transformações

\footnotetext{
${ }^{414}$ Fiori, José Luís. O sistema interestatal capitalista no inicio do século XXI. In: Medeiros, Carlos Aguiar de; Da Costa, José Luís; Serrano, Franklin P. O mito do colapso...Op. Cit.,p.22/23 e 33/34.

${ }^{415}$ Fiori, José Luís. Ibid, p. 34.
} 
na economia e política mundiais em curso nos dias de hoje. Apoiando-se na trajetória de financeirização e de desregulamentação do capital ao longo desses anos, José Luis Fiori aponta que os EUA não só foram os lideres desse processo trazendo "de volta ao sistema mundial, depois de 1991, as duas velhas potenciais do século XIX, Alemanha e Rússia, além de incluir dentro do sistema, China, Índia, e quase todos os principais concorrentes dos Estados Unidos deste início de século" ${ }^{416}$, como também eles se transformaram no mercado financeiro mundial e no emissor de moeda de circulação internacional a ponto da atual crise expressar um paradoxo: mesmo os EUA estando no epicentro dela, os capitais do mundo todo e, sobretudo, dos Estados intitulados ameaçadores da hegemonia americana (China) buscam refúgio no dólar e nos títulos americanos (de baixa rentabilidade). Esta contradição, no entanto, dissolve-se facilmente se olhar para o poder político e econômico americano.

José Luis Fiori, assim, arremata dizendo que não haverá uma sucessão chinesa na liderança política e econômica do mundo, o que haverá provavelmente é uma fusão maior entre as duas economias; interpenetração essa, aliás, já propalada por um influente economista chinês Yuan Gangming quando se referiu ao provável destino dos excedentes comerciais chineses. Conclui, por fim, o autor afirmando que "a crise atual começou como um tufão, mas deverá se prolongar na forma de uma epidemia darwinista que irá liquidando os mais fracos, por níveis sucessivos, nacionais e internacionais, e aprofundará a corrida imperialista que começou nos anos de 90. Na hora da volta do sol poucos estarão na praia, mas com certeza os EUA ainda estarão na frente deste grupo seleto. E quase todos os países que estavam ascendendo nas duas últimas décadas e desafiando a ordem internacional estabelecida, serão recolocados no seu lugar. Neste período haverá resistência e haverá conflitos sociais agudos, e se a crise se prolongar, deverão se multiplicar as rebeliões sociais e as guerras civis nas zonas de fratura do sistema mundial, e é provável que algumas destas rebeliões voltem a se colocar objetivos socialistas. Mas do nosso ponto de vista, não haverá uma mudança de modo de produção em escala mundial, nem tampouco ocorrerá uma superação hegeliana, do sistema inter-estatal capitalista." ${ }^{417}$

Quanto aos domínios dos direitos sociais, a questão candente é: será que os esquemas de proteção social neoliberais darão um resultado satisfatório para arrefecer as conseqüências da crise econômica, e mais, será que os Estados apresentarão o mesmo grau de presteza e de agilidade em defesa do social tal como o ocorrido com o capital (financeiro)?

\footnotetext{
${ }^{416}$ Fiori, José Luís. Os economistas e a crise...Op.Cit.

${ }^{417}$ Fiori. José Luís. Ibid.
} 


\section{3) Terceira aproximação - A jurídica - especificidades do texto constitucional}

Feitas as considerações pretéritas, neste momento, pode-se adentrar em algumas especificidades do texto constitucional no que tange a não concretização dos direitos sociais. Tendo por pano de fundo a não realização dos preceitos da Constituição de 1988 é tarefa do presente extrato explorar a especificidade da interface entre seguridade e direito tributário e financeiro, deixando para o item subsequente, apenas para fins didáticos, a problemática quanto às possibilidades afetas à política para a consecução ou não da realidade normativa proposta pela Constituição de 1988.

A aproximação há de ser iniciada a partir do direito tributário inscrito na Constituição e mais especificadamente a questão da chamada "progressividade tributária, segurança e justiça fiscal" ${ }^{418}$. Os princípios constitucionais tributários gravitam em torno da certeza (segurança jurídica do contribuinte) instrumentalizada pelo princípio da legalidade e da "justiça" consubstanciada ao redor de princípios como isonomia, não confisco, capacidade contributiva, etc... cujo embate, na superfície, está em identificar a alíquota única à certeza e a alíquota progressiva à justiça, sem interrogar sobre o verdadeiro potencial da progressividade para ambas as searas.

Calciolari arrola os argumentos pró e contra uma eventual função redistributiva do tributo baseado no conceito de capacidade contributiva ("proporção entre quantum pago por cada cidadão e sua capacidade de pagar determinado tributo"), mostrando que hoje as críticas em torno da progressividade, como fator de redistribuição de renda social, transcendem a esfera tributária indo para a seara financeira e, mais especificamente, às decisões políticas de alocação do gasto público, pois "uma tributação equânime, em bases proporcionais, com gastos públicos distributivos já seria suficiente para garantir o fim de redução das desigualdades do nosso Estado Social" ${ }^{419}$. Este tema será trabalhado em seguida, mas, desde já, pode-se afirmar que este último ponto deverá ser aprofundado.

Para além da celeuma, Calciolari afirma que a progressividade se corretamente aplicada - em relação ao quanto e à forma de incidência - e se somada a outros elementos, tais como base de cálculo e deduções não só não afetam a igualdade na tributação, como também contribuem para uma efetiva redistribuição de renda, desde que tenham como contrapartida os gastos públicos aplicados no social.

\footnotetext{
${ }^{418}$ Calciolari, Ricardo Pires. Progressividade tributária, segurança e justiça fiscal. Revista Tributária e de Finanças Públicas, São Paulo, ano 15, n 76, set/out 07, p.198/225.

${ }^{419}$ Calciolari, Ricardo Pires. Ibid, p.212.
} 
Esta assertiva é retirada da análise da incidência da progressividade nos impostos sobre o patrimônio, renda e consumo de onde se depreende, em apertada síntese, que: i) a tributação progressiva aplicada apenas sobre o patrimônio imobiliário não apresenta viés distributivo, limitando-se como é o caso do IPTU ao fomento da função social da propriedade; ii) a tributação progressiva sobre o consumo em termos individuais é, por sua própria natureza, regressiva, "é fato notório que pessoas menos abastardas economicamente tendem a consumir grandes percentuais de sua renda (quando não a sua totalidade), ao passo que pessoas abastardas consomem percentuais menores de sua renda, sendo o restante acumulado (formando o patrimônio). Deste modo, um percentual aplicado ao consumo individualmente considerado afetará os menos abastados de forma mais gravosa (em termos percentuais)" ${ }^{420}$. E, o viés regressivo dessa modalidade de tributo enseja, ainda, outras duas características - seletividade e a essencialidade enquanto modos de mitigar os efeitos da tributação sobre o consumo final; iii) tributação progressiva sobre a renda justamente por ser a renda o elemento que melhor expressa a capacidade contributiva é aquele que melhor se adéqua à justiça distributiva quando comparado aos dois outros tributos.

Em que pese à perspicácia do autor na conjugação da técnica da progressividade com os gastos públicos voltados para o social, a realidade objetiva contradiz a ideia de justiça distributiva. Primeiro, porque a arrecadação do Estado é em grande medida pautada pelos tributos indiretos ${ }^{421}$ de onde se depreende o viés da regressividade e, por conseguinte, da injustiça social, dada a premência dos impostos indiretos, que gravam os trabalhadores como consumidores.

Depois porque se vislumbra uma estrutura liberalizante dos impostos diretos (aqueles que recaem sobre os lucros, sobre as manifestações de riqueza; em suma, sobre o capital), dando mostras não só da contraditoriedade, como também da permissividade da Constituição Federal, como fonte incapaz de organizar um sistema tributário "mais equitativo". Esse descompasso no perfil tributário das classes sociais se faz presente na chamada "crise fiscal do Estado" que ao invés de ser equalizada pelo ingresso de receitas advindas de uma tributação maior das classes dominantes, acentua a desigualdade quando realiza o ajuste das contas públicas pela redução do gasto público. Para um estudo mais coerente dos gastos públicos e, em especial, dos gastos sociais, é necessário passar em revista o orçamento da seguridade social em suas duas pontas: custeio e despesas.

\footnotetext{
${ }^{420}$ Calciolari, Ricardo Pires. Progressividade tributária, segurança e justiça fiscal. Revista Tributária e de Finanças Públicas...Op.Cit., p.219.

${ }^{421}$ Borón, Atilio. A sociedade civil depois do dilúvio neoliberal. In: Sader, Emir; Gentili, Pablo (org). PósNeoliberalismo...Op. Cit., p. 88/89.
} 
Primeiro, é preciso abordar com seriedade o tema da existência de um possível déficit na previdência (RGPS), bem como de sua não sustentabilidade ao longo dos anos, pois este é um dos argumentos a fundamentar as investidas reformistas contra os direitos sociais e a balizar a "cultura da crise" desenhada em torno do descompasso existente entre proteção social universalizada e globalização, responsabilizando aqueles pelos problemas econômicos do país. A proposta reformista tem por pano de fundo não apenas pavimentar o trajeto para o sistema de previdência complementar, ao conjugar um teto de benefícios para o RGPS com incentivos tributários para o regime privado, mas também apropriar-se do fundo público pela passagem do gasto social para o financeiro.

Já em 2007, a Anfip (Associação Nacional dos Auditores Fiscais da Receita Federal do Brasil) apresentou um estudo ${ }^{422}$ pertinente ao orçamento da seguridade social relativo ao ano de 2006, no qual descortina os mitos balizadores da pretensa nova reforma da previdência social, a saber: i) demográfico: premente necessidade de se estabelecer uma idade mínima para aposentadoria em virtude do aumento da expectativa de vida do brasileiro; ii) orçamentário: o desequilíbrio na previdência não pode ser eternamente sustentado pelo tesouro nacional; iii) a aposentadoria rural tem natureza assistencial, pois o trabalhador rural não fez aportes ao regime geral; iv) enfrentamento da pobreza, assentado na premissa de que, nesse escaninho, os benefícios assistenciais focalizados são mais eficazes que os previdenciários.

Os números desta associação mostraram que a seguridade social, cujas receitas são compostas basicamente com contribuições sociais (incidentes sobre: salários e rendimentos do trabalho, faturamento - Cofins, lucro das empresas - CSLL, PIS/PASEP, concurso de prognósticos, correção do FGTS), e as despesas envolvem gastos com previdência, saúde, assistência, mais subsídios e renúncias tributárias, apresenta resultado superavitário para não dizer desde sempre, mas muito acentuado a partir de 1999, ou seja, antes mesmo do crescimento econômico experimentado pelo país em meados da década de 2000.

Não é de se estranhar a data de 1999, pois foi a partir daí que o governo adotou a política de ajuste fiscal e superávit primário assentada na elevação das receitas das contribuições sociais e na DRU (mecanismo que autoriza a União desvincular $20 \%$ das receitas de impostos e contribuições para outras finalidades), originada nos idos de 1994 sob o nome de Fundo Social de Emergência (FSE), fazendo com que parte relevante do orçamento

\footnotetext{
${ }^{422}$ Anfip. Análise da seguridade social em 2006. Brasília: Anfip. Disponível em: http://www..anfip.org.br/publicações/livros/arqs-swfs/analise_2006swf. Acessado em 12/08/09.
} 
da seguridade social fosse vertido para a conta do tesouro a fim de compor o superávit primário do orçamento fiscal.

Em 2006, por exemplo, pagou-se em serviços da divida R\$ 600 bilhões (aproximadamente 26\% PIB nacional), o orçamento da seguridade social foi de $\mathrm{R} \$ 303$ bilhões (aproximadamente 13\% PIB nacional) e o superávit da seguridade foi da ordem de R\$ 48 bilhões (antes da DRU) e só a DRU retirou cerca de R $\$ 34$ bilhões de seu orçamento. Isso sem contar outros artifícios, tais como a retenção pelo tesouro e gastos em outros órgãos, todos eles imbuídos no intuito de desviar parcela do orçamento da seguridade para o tesouro. Em 2006, o total retido ou desviado via DRU do orçamento da seguridade foi de $\mathrm{R} \$ 52$ bilhões. Os dados da Anfip para os propósitos desta dissertação não são por ora conclusivos, mas são relevantes para marcar desde já a tendência da trilha do fundo público - do social para o financeiro e não o reverso como é ventilada pela grande mídia.

É importante ressaltar que não se objetiva aqui fazer uma análise econômica da seguridade social no Brasil mas sim mostrar como se deu e ainda se dá a passagem de um pretenso Estado social para um Estado liberal. Parte desta análise, foi desenvolvida no capítulo I, de onde se depreende a importância da financeirização e da alteração das forças produtivas (fordismo para o toyotismo), restando aqui trabalhar uma segunda linha de argumentação complementar àquela, qual seja: se no Welfare, os gastos sociais em sua maioria são financiados pelos trabalhadores. Em um Estado neoliberal, esses gastos sociais são remediados em prol do orçamento fiscal, mais especificamente, dos credores da dívida pública, fazendo ao final com que a exploração da classe trabalhadora ocorra para muito além da esfera da produção ou mesmo de um modelo de Welfare. Para tanto, cabe aqui passar para uma segunda etapa, qual seja: um breve Raio X da arrecadação da seguridade.

Os dados da Anfip ${ }^{423}$ relativos, a 2008, colhem o período de crescimento econômico e do mercado de trabalho dos 5 últimos anos, mais o aumento do salário mínimo acima da inflação do período (46\% em termos reais, ou seja, acima da inflação do período de 2003 2008), e a expansão dos gastos da seguridade com maior destaque para a assistência (acima dos $200 \%$ no período) seja em razão da ampliação da cobertura do LOAS, do Bolsa Família, bem como da política do salário mínimo, cujo resultado traduzido em números mostra uma redução de $60 \%$ nos níveis de pobreza e de $65 \%$ nos níveis de indigência nos últimos 4 anos, segundo PNAD/IBGE.

\footnotetext{
${ }^{423}$ Anfip. Análise da seguridade social em 2008. Brasília: Anfip, 2009. Disponível em: http://www.anfip.org.br/publicacoes/livros/arqs-pdfs/analise_2008.pdf. Acessado em: 12/08/09.
} 
A expansão das despesas sociais mais a perda de receitas (fim da CPMF) não alteraram o quadro-base, ou seja, a seguridade continuou superavitária (R\$ 52 bilhões), permitindo a desvinculação de suas receitas para o orçamento fiscal, via o mecanismo da DRU, na ordem de R\$ 39 bilhões. O fator mais importante para esse resultado foi, sem dúvida, o crescimento econômico acompanhado da maior formalização da economia, acarretando o incremento da arrecadação com maior aporte de recursos, tanto para os gastos sociais como aos financeiros (superávit e ajuste de contas públicas). E mais, os números mostram uma relativa "vitalidade" deste sistema de arrecadação plural provedor/mantenedor de um Estado social. Com a crise de 2008/ a tendência é de retração da arrecadação com pressão maior pelo aumento dos gastos públicos - investimento e social - o que terá reflexos na equação da seguridade, caso se mantenha a linha neoliberal de privilegiamento dos gastos financeiros.

Mais do que o estudo das despesas da seguridade que representam 10,8\% do PIB (a previdência responde por $\mathrm{R} \$ 200$ bilhões ou 6,9\% do PIB, suplantando em muito a assistência com R $\$ 26$ bilhões ou 0,5\% do PIB, a saúde R \$ 50,3 bilhões ou 1,8\%PIB e os benefícios do FAT - seguro desemprego e abono salarial - com R \$ 20,7 bilhões ou 0,7\% PIB), o relevante desse relatório é a análise que a associação faz das receitas da seguridade cujos números, para 2008, são os seguintes: R \$ 119,3 bilhões arrecadados com o COFINS, desvinculados R $\$ 23,8$ bilhões pela DRU; R \$ 42,4 bilhões de CSLL, desvinculados R \$ 8,4 bilhões; R \$ 30,8 bilhões com o PIS/PASEP, desvinculados R $\$$,1 bilhões e $\mathrm{R} \$ 163,4$ bilhões com contribuições previdenciárias, e desse montante $\mathrm{R} \$ 89,7$ bilhões (55\% desse total) são oriundos de contribuições patronais sobre a folha de salários e R \$ 35,2 bilhões (21,5\%), dos segurados, não havendo para essa espécie de contribuição a incidência da DRU. No entanto, isso não impede que eventuais retenções promovidas pelo tesouro possam atingir inclusive, as contribuições previdenciárias (em 2008, foi na ordem de $1 \%$ ou $\mathrm{R}$ \$ 1,6 bilhão).

Some-se, ainda, que tramita, no Congresso Nacional, uma PEC 233 que, em apertada síntese, objetiva acabar com o modelo de financiamento plural da seguridade, ficando ela somente com as contribuições previdenciárias, como fonte de custeio. Aliás, esse é o modus operandi do "cálculo do déficit da previdência" que prevê como receitas apenas essas contribuições e como despesas, os três níveis - previdência, assistência e saúde.

Por fim, não se pode esquecer que o perfil de financiamento da seguridade segue pari passo o do sistema tributário, em que se privilegia a tributação indireta - sobre o consumo - ao invés de tributar a renda e o patrimônio de forma que até a própria seguridade é eivada de distorção, fazendo com que, ao final das contas, o trabalhador seja seu maior 
contribuinte. Só a titulo de exemplo, sem adentrar em detalhes, basta olhar os números do COFINS e da CSLL que, respectivamente, aportam para a seguridade $\mathrm{R} \$ 95,5$ bilhões $(119,3$ - 23,8) e R\$ 34 bilhões $(42,4$ - 8,4). Estas singelas considerações sinalizam que os gastos sociais são financiados em grande parte pelos próprios trabalhadores, fazendo com que as eventuais redistribuições de renda se processem horizontal e não verticalmente, ao reverso do que é extraído do senso comum.

Esta ponderação abre flanco para robustecer a discussão sobre o próprio Estado social e funcionamento do sistema capitalista, discussão essa iniciada por Francisco de Oliveira no livro Os direitos do antivalor, no qual se retiram duas reflexões cruciais para a presente dissertação: o salário indireto e o fundo público.

$\mathrm{O}$ autor ${ }^{424}$, sem esquecer que o Estado capitalista é um estado de classes, constata que esse mesmo Estado de "comitê executivo da burguesia" torna-se o local, por excelência, da luta de classes quando o assunto é seu orçamento, e a razão para tanto é a potencialidade da democracia, no mínimo, a do tipo representativa, como sistema autorizador da edificação de um espaço público marcado pela alteridade. As relações sociais passam a ser concebidas e desenvolvidas na base do reconhecimento, quer seja da legitimidade ou da necessidade dos interesses do outro, para além da concentração e exclusão ínsita a lógica do mercado e do capital, de forma a lograr a reprodução social como um todo, preservando, assim, essa mesma alteridade que informou a relação.

A construção desta esfera pública indissociada da consolidação da própria democracia transcende a "valorização do valor de per si", de forma a dar guarida às necessidades outras - melhoria da condição de vida e criação de um estado de bem estar geral. Aqui reside a ontologia dos direitos sociais, sendo estes necessidades apriorísticas de per si, alheio a qualquer função instrumental.

Daí, pode-se depreender, na origem, o direito social como antimercadoria ${ }^{425}$ - pois sua finalidade imediata não é o lucro nem a mais-valia, posto que objetiva melhorar as condições de vida material, a ponto de Francisco de Oliveira afirmar que, pelos direitos sociais, existe uma tendência a "desmercantilização da força de trabalho". Isso ocorre, pois o salário indireto (gasto público com saúde, educação, transporte, dentre outros) é antimercadoria social, modificando, assim, a clássica equação do capitalismo: M-D-M' pela introdução do "anti-M" nas duas pontas.

\footnotetext{
${ }^{424}$ De Oliveira, Francisco. Os direitos do antivalor. A economia política da hegemonia imperfeita. Petropólis: Vozes, 1998, p. 37/43.

${ }^{425}$ De Oliveira, Francisco. Ibid, p.29/37.
} 
Esse ingresso tem por conseqüência tanto a redução da taxa da mais valia, como a autonomização do capital constante, apartando, assim, a inovação e o desenvolvimento tecnológico de sua amarra clássica - aumento de salário real direito. Essa linha de pensar conduz Francisco de Oliveira a conceituar o "fundo público" do Welfare como um "não capital", como um "antivalor" ("no sentido de que os pressupostos da reprodução do valor contêm, em si mesmos, os elementos mais fundamentais de sua negação"), porquanto ele não se limita a ser a contrarrestante da tendência da queda da taxa de lucro.

$\mathrm{Na}$ verdade, o fundo publico é o elemento viabilizador da "concretização das oportunidades de expansão, em face da insuficiência do lucro frente ao progresso técnico. (...) A consequiência teórica mais profunda é que a lei da tendência declinante da taxa de lucro se afirma pela retração da base social global da exploração."426 Essa desmercantilização - "anulação do fetiche da mercadoria" - dá-se, pois a remuneração da força de trabalho pelo salário ganha em transparência no sentido de que sua determinação passa a ser política. Trata-se da natureza dos gastos sociais - salário indireto - e "a luta política que se trava para fazer corresponder a cada item do consumo uma partida correspondente dos gastos sociais. (...) Ou, em outras palavras, a fração do trabalho não pago, fonte da mais valia, se reduz socialmente" ${ }^{\text {427. }}$.

Como ontologia, o pensamento de Francisco de Oliveira não é objeto de qualquer reparo, o problema reside justamente em sua concretização, seja pelo lado do financiamento, de sua implementação ou, ainda, da estrutura da qual se vale - direito subjetivo, elemento esse analisado no capítulo precedente.

No capitalismo, tratar os direitos sociais, para além do seu aspecto filosófico, como antimercadoria padece de uma dificuldade imediata, a saber: a questão da origem do recurso público que em grande monta advém de impostos sobre o consumo e trabalho e, assim, a desmercantilização não se realiza, ao reverso, ela pode ser "potencializada" por via oblíqua. Roseli Martins Coelho, na tese de doutoramento denominada Social Democracia: a chantagem do capitalismo, depois publicada com o nome de Social-Democracia Formas e Reformas $^{428}$, investe sobre o padrão de financiamento do fundo público, alertando não ser possível concluir, categoricamente, que no Estado social há, de fato, uma transferência de renda vertical entre as classes. Isso porque, em primeiro lugar, atrelar gasto público ao PIB invariavelmente escamoteia o quantum desse gasto público com a reprodução do capital,

\footnotetext{
${ }^{426}$ De Oliveira, Francisco. Os direitos do antivalor...Op.Cit.,p.34.

${ }^{427}$ De Oliveira, Francisco. Ibid, p.35.

${ }^{428}$ Coelho, Roseli Martins. Social-democracia: formas e reformas. São Paulo: Humanitas/FFLCH/USP e FESPSP, 2001, p. 77/85.
} 
“expressos na divida pública nos grandes países capitalistas, financiando as frentes de ponta da terceira revolução industrial." 429

Em seguida, Roseli Martins Coelho alinha-se com Francisco de Oliveira no que tange ao barateamento e autonomização da força de trabalho para o capital, na medida que é revelada a "tendência à socialização dos custos de reprodução da força de trabalho" "430 . No entanto, afasta-se e aí está a segunda objeção (participação do salário indireto no salário total), ao perquerir quanto a seu financiamento, na medida que a homogeneização na estrutura do próprio salário entre as parcelas salário direito e salário indireto não significa dizer que o salário indireto seja arcado pelo capital. Dados apresentados acima pela ANFIP e mais os números trazidos pela autora, quanto ao padrão alemão de financiamento nos anos de 1980431 referendam a tese de que os benefícios sociais em um Welfare são custeados em parcela muito significativa pela classe trabalhadora, desmistificando a ideia de que o Estado social seria um "Robin Hood", ou seja, de que seus custos seriam arcados preponderantemente pelo Capital.

Seguindo com o trabalho de Francisco de Oliveira, o autor afirma que a desmercantilização da força de trabalho se, de um lado, tem a virtude de mostrar a "finitude da forma mercadoria" pela incapacidade do lucro em continuar financiando o processo acumulativo no capitalismo avançado, devendo, agora, o capital (seu setor oligopolista), para continuar a reproduzir-se, apropriar-se da riqueza pública como condição sine qua non - o acesso e o manejo desse recurso informam a questão que está por de traz do neoliberalismo: reequacionar a utilização e a distribuição da riqueza pública, pela supressão da alteridade, pela dissolução da arena de confronto e de negociação, a fim de reduzir o Estado ao mínimo Estado caritativo ${ }^{432}$.

Do outro lado, tal concepção esbarra no núcleo elementar do capitalismo - força de trabalho como mercadoria singular, porquanto realizadora da mais valia - o que leva de imediato não só a questão da autonomização do capital constante como também a perda da centralidade do trabalho nas sociedades desenvolvidas ${ }^{433}$.

O parágrafo acima merece ser desdobrado em dois. A primeira parte, a passagem mais brilhante do trabalho - Os direitos do antivalor - colhe a internacionalização da economia

\footnotetext{
${ }^{429}$ Coelho, Roseli Martins. Social-democracia: formas e reformas...Op. Cit., p.79.

${ }^{430}$ Coelho, Roseli Martins. Ibid, p.79.

${ }^{431}$ Discorrendo sobre a social democracia alemã, a autora apresenta "as origens da arrecadação de impostos", pertinente ao ano de 1987, a qual releva que a classe trabalhadora alemã é responsável pela maior parte do bolo arrecadado das formas mais diversas, sejam elas: impostos sobre o consumo (perfazendo um terço do total), impostos sobre a renda tanto das empresas quanto dos trabalhadores (aproximadamente 36\% do total), impostos sobre óleo e gasolina (15\% do total) e sobre tabaco (9\% do total). Coelho, Roseli Martins. Ibid, p.57.

${ }^{432}$ De Oliveira, Francisco. Os direitos do antivalor...Op.Cit.,p.43/48.

${ }^{433}$ De Oliveira, Francisco. Ibid, p.57/58.
} 
e a segunda parte, remonta a "passagem da sociedade de trabalho para a de consumo", viés acompanhado de perto pelo direito e pelo discurso ideológico, assunto esse abordado e refutado no corpo desta dissertação, que, em apertada síntese, busca denunciar uma dentre tantas falácias desse discurso neoliberal quando propugna transformar o conflito interclasses uma modalidade de cooperação entre elas.

Quanto à primeira, residindo aí à aguda percepção de Francisco de Oliveira ao descrever a mudança de função do fundo público quando passa do Estado social para o neoliberal, nesses dizeres: "O rompimento do círculo perfeito do Estado-providência, em termos Keynesianos, é devido, em primeira instância, à internacionalização produtiva e financeira da economia capitalista. A regulação keynesiana funcionou enquanto a reprodução do capital, os aumentos de produtividade, a elevação do salário real, se circunscreveram aos limites - relativos, por certo -, da territorialidade nacional dos processos de interação daqueles componentes da renda e do produto. Deve-se assinalar, desde logo, que aquela circularidade foi possível graças ao padrão de financiamento público do Welfare State, um dos fatores, entre outros aliás, que levaram à crescente internacionalização. Ultrapassados certos limites, a internacionalização produtiva $e$ financeira dissolveu relativamente a circularidade nacional dos processos de retroalimentação. Pois des-territorializam-se o investimento, e a renda, mas o padrão de financiamento público do Welfare não pôde - nem pode, até agora - des-territorializar-se. Em outras palavras, a circularidade anterior pressupunha ganhos fiscais correspondentes ao investimento e à renda que o fundo público articulava e financiava; a crescente internacionalização retirou parte dos ganhos fiscais, mas deixou aos fundos públicos nacionais a tarefa de continuar articulando e financiando a reprodução do capital e da força de trabalho. Daí que, nos limites nacionais de cada uma das principais potências industriais desenvolvidas, a crise fiscal ou o que um ganha é o que o outro perde emergiu na deterioração das receitas fiscais e parafiscais (previdência social, por exemplo), levando ao déficit público." ${ }^{434}$

Esta trajetória baliza aquilo que Bercovici e Massonetto apregoam de "Constituição dirigente invertida: a blindagem da constituição financeira e a agonia da constituição econômica", podendo ao termo acrescer mais uma agonia: a da "constituição social", nas palavras de Calciolari.

\footnotetext{
${ }^{434}$ De Oliveira, Francisco. Os direitos do antivalor...Op.Cit.,p.26.
} 
A propalada conjugação de financeirização e desenvolvimento tecnológico ${ }^{435}$, a partir dos anos de 1970, repercutiu no processo de acumulação que dentre as inúmeras modificações já descritas nesse texto, avança ainda mais sobre o fundo público ao adotar como fio condutor a política monetária de juros altos que, no limite, desloca o gasto público do social para o capital.

Assim, em um país periférico, como é o Brasil, as dificuldades se potencializam, pois em face da insuficiência dos recursos públicos, a atração do capital há de ser pela estabilização do "valor real dos ativos das classes proprietárias. Ou seja, o orçamento público deve estar voltado para a garantia do investimento privado, para a garantia do capital privado em detrimento dos direitos sociais e serviços públicos voltados para a população mais desfavorecida." 436 Daí, então, a emergência do direito financeiro em seu novo papel - da tutela jurídica da acumulação capitalista, centrada agora na segunda fase da equação D-M-D', ou seja, na forma DD'.

O primado do orçamento monetário sobre o fiscal capitaneado pela política de estabilização monetária reflete, ou melhor, deforma a Constituição de 1988 em dois espectros: seja na "blindagem" da constituição financeira, cuja consequência é sentida na formação da "constituição dirigente invertida"437. A primeira é fruto do não diálogo entre a ordem financeira e a econômico-social, conforme aquela se dissocia desta quando se volta à ordem internacional, objetivando ser o arauto da confiança e da credibilidade do país, direcionando o orçamento estatal para os investimentos privados ou para a especulação financeira e remetendo à ordem econômica e social ao plano secundário.

Referendando esse novo desenho, chamado por Bercovici de "constituição econômica invertida", vem o tradicional discurso do déficit público e da ingovernabilidade causados pelos direitos sociais que dão o tom da "verdadeira constituição dirigente" - das políticas de ajuste fiscal - que vincula as políticas do Estado à acumulação privada.

Como mecanismo de exasperação do receituário liberal, o direito tributário ${ }^{438}$ é convocado para robustecer o superávit primário via aumento de carga tributária, sobretudo, nas contribuições sociais (de relativo equilíbrio entre os aportes advindos dos impostos e das

\footnotetext{
${ }^{435}$ Bercovici, Gilberto; Massonetto, Luís Fernando. A constituição dirigente invertida: a blindagem da constituição financeira e a agonia da constituição econômica. Coimbra: Boletim de Ciências Econômicas XLIX, 2006, p. 13/23.

${ }^{436}$ Bercovici, Gilberto; Massonetto, Luís Fernando. A constituição dirigente invertida...Op.Cit., p.15.

${ }^{437}$ Bercovici, Gilberto; Massonetto, Luís Fernando. Ibid, p.17.

${ }^{438}$ Calciolari, Ricardo Pires. A crise de efetividade dos direitos sociais e a desvinculação de receitas. In: Da Rocha, Daniel Machado; Savaris, José Antonio (coord). Curso de Especialização em Direito Previdenciário. Vol. 3, Custeio da Seguridade Social. Curitiba: Juruá Editora, 2008, p. 62/65.
} 
contribuições para o caixa do tesouro em 1994; o volume arrecadado pelas contribuições praticamente dobrou em comparação com o dos impostos no ano de 2007).

Apresentam aqui duas derivações importantes: a primeira retoma o dito nesse item quanto ao perfil de financiamento do Estado - associação entre tributos indiretos e não redistribuição vertical de renda. A segunda, essa sim é novidade, pois, na prática, põe em cheque a forma federativa do Estado, dada a diferença invencível entre as competências materiais dos entes federados e suas necessidades orçamentárias, deixando uma única válvula de escape - a da guerra fiscal, que nada mais é do que a disputa entre os entes da federação por investimentos privados, e, ainda, sabota a operacionalização descentralizada da seguridade social.

A deformação do arcabouço constitucional engendrada a partir do perfil tributário do Estado e, em particular, da seguridade social, somado aos desvios de toda forma (sejam eles legais ou contábeis para fins outros), redunda na agonia da ordem econômica e social. O pano de fundo da crise de efetividade dos direitos sociais tem a ver com o modelo de Estado, proposto ou imposto, modelo esse que jamais se dissocia do processo de acumulação capitalista.

Assim, pode-se dar por finalizados os aspectos econômico e jurídico, não porque a análise tenha sido exaustiva mas sim porque esses dois elementos isolados ou associados são insuficientes para a compreensão total dos direitos sociais, bem como de seu fluxo e refluxo, exceto se atentar para o aspecto político, ou melhor, para suas possibilidades ou impossibilidades de estabelecer, no Brasil, um Estado Social, objeto do próximo item.

\section{Esforço final, a Constituição de 1988}

4.1) Vicissitudes do caso brasileiro

"De modo geral, a social democracia teve o mérito histórico de apostar na possibilidade, já prevista por Marx, de conquistar reformas favoráveis aos trabalhadores ainda no interior da ordem capitalista. É inegável que o conjunto de reformas que se consolidou no Welfare State - o grande produto histórico da social-democracia e hoje o principal alvo da reação neoliberal - representou uma expressiva vitória dos trabalhadores. Mas também é inegável que o reformismo da social democracia (...) cedo se revelou um reformismo tímido e limitado: sempre que o movimento das reformas se chocou com a lógica 
do capital, a social- democracia tendeu a abandonar sua própria estratégia reformista (...) e a adotar políticas que, em última instância, favoreciam os mecanismos de acumulação capitalista (...) Se a experiência da social democracia nos ensina que é possível conquistar reformas substantivas ainda no interior do capitalismo, ensina-nos também que - se essas reformas não forem claramente dirigidas contra a lógica do capital - elas se tornam frágeis, instáveis e terminam por serem abandonadas." 439

Em que pese o Brasil não ter galgado o status de Estado de Bem Estar Social ${ }^{440}$, o alerta acima de Carlos Nelson Coutinho é o pano de fundo para a apreensão do momento nacional, cuja história, na origem, aparta-se da ocidental européia; mas que, hoje, diante do fenômeno da globalização, todos os países enfrentam dificuldades, em maior ou menor grau, no que tange aos domínios dos direitos sociais.

A singularidade do caso brasileiro é aquilo que Octavio Ianni $^{441}$ batizou de "contrarrevolução burguesa permanente" caracterizada pelo autoritarismo das soluções "conciliação pelo alto" - cuja expressão maior era os dizeres - "Ordem e Progresso" dos modelos oligárquico e populista e, depois "Segurança e Desenvolvimento" do Estado militar. Estas alusões são significativas como representações de um modelo burguês pautado, em síntese, pela presença de um Estado forte e organizado com vistas a manter a sociedade débil, seja pelo descaso e desprezo no tratamento das conquistas democráticas elementares obtidas ao longo da história ou pela marginalização e repressão das classes subalternas, com o fim último de impedir que estas classes fizessem política e pudessem, ao menos, consolidar uma ordem democrática burguesa para o país e acrescente ao quadro a inserção e o papel (periférico) do país no âmbito das relações capitalistas internacionais, elemento esse a pautar a história brasileira no século XX.

Em uma linha semelhante, Florestan Fernandes deitou-se sobre o processo da revolução burguesa no Brasil, atribuindo-lhe a alcunha de "associação racional entre

\footnotetext{
${ }^{439}$ Coutinho, Carlos Nelson. Contra a corrente...Op. Cit., p.78 e 88.

${ }^{440} \mathrm{O}$ tratamento que os autores suecos dão ao tema da social democracia, via de regra, junge-se a idéia de um Estado anti-capitalista, no sentido de desmercantilização da força de trabalho, premissa essa que aqui não está em discussão, mas é passível de contestação conforme se verificou, principalmente, no item anterior. O que de fato é relevante nesse instante para a questão brasileira remete a classificação de Esping-Andersen quanto aos assim chamados regimes de Welfare State (liberal de países anglo-saxões; o corporativismo estatal de países europeus continentais; social-democrata dos escandinavos) os quais têm a sua razão de ser assentadas em três fatores: mobilização de classe, estruturas de coalizão política das classes, legado histórico da institucionalização do regime - sendo eles fundamentais não só para explicar o passado, como também para refletir nas suas perspectivas futuras diante do avanço neoliberal. Essa classificação é importante para situar o debate em torno dos direitos sociais no Brasil pós 1988 na medida em que serve de régua para estabelecer qual o modelo atingido efetivamente por um país de industrialização tardia. Esping-Andersen, Gosta. As três economias políticas do Welfare State. Lua Nova, Cedec, n²4, Set/91, p. 108/116.

${ }^{441}$ Ianni, Octavio. O ciclo da revolução burguesa. Petrópolis: Vozes, 1984, p. 20/24 e 38.
} 
desenvolvimento e autocracia" pautada na maximização do elemento político, a fim de possibilitar a "apropriação dual" do excedente econômico pelas burguesias local e internacional.

Mais uma vez, tal como trazido no capítulo anterior, denota-se a essencialidade do elemento político para o sistema capitalismo, na medida que "a revolução burguesa na periferia é, por excelência, um fenômeno essencialmente político (...) Tanto as burguesias nacionais da periferia quanto as burguesias das nações capitalistas centrais e hegemônicas (...) Elas querem: manter a ordem, salvar e fortalecer o capitalismo, impedir que a dominação e controle burguês sobre o Estado nacional se deteriorem" valerão de "formas abertas e sistemáticas de ditadura de classe."

E mais, é sempre nos limites extremos, ${ }^{443}$ sejam eles do processo inicial de acumulação ou das crises econômicas advindas do desencaixe entre produção e apropriação, que o elemento político se faz necessário para corrigir as insuficiências do econômico, vindo a referendar o sinergismo existente entre as relações econômicas e políticas como processo único de produção e reprodução do sistema capitalista.

O diferencial com relação às revoluções burguesas retardatárias ${ }^{444}$ remete à questão da "apropriação dual", a qual se deita de plano na insuficiência ou na inexistência de uma base material sólida, incapacitando a burguesia local a realizar seu papel histórico, o que, por consequência, deriva não só na impossibilidade de se pensar um projeto de país, como também de limitar o horizonte de inclusão do país na comunidade internacional, posicionando-se secundária ou perifericamente. Desse modo, o papel dessas burguesias fica restrito: no plano interno, a consolidar e a garantir seus privilégios de classe; no plano externo, a aderir ao sistema vigente e, mais especificamente, sua manutenção, porquanto o capitalismo opera e desenvolve-se pela "parceria" entre nações postas na relação centro/periferia. A tarefa desse tipo é factível para a burguesia por uma única via, a saber: a conversão do Estado em "ditadura de classe preventiva".

Este foi, em síntese, o percurso histórico do Brasil que, ao cabo desse ciclo eivado de contradições, sejam elas no interior da classe dominante, ou dela, com a classe dominada, ou, ainda, no interior desta última, deságua em um "novo pacto social”, que atende pelo nome

\footnotetext{
${ }^{442}$ Fernandes, Florestan. A revolução burguesa no Brasil: ensaio de interpretação sociológica. 5 ed. São Paulo: Globo, 2006, p. 343.

${ }^{443}$ Sader, Emir. Estado e política em Marx...Op.Cit.,p.51.

${ }^{444}$ Fernandes, Florestan. A revolução burguesa no Brasil...Op.Cit.,p.344/346.
} 
de Constituição Federal 1988, cujo distintivo com relação aos diplomas anteriores ${ }^{445}$, é ser informador de uma ordem democrática assentada nos direitos sociais e que irá se deparar, de plano, com dois legados imediatos da ditadura - a crise econômica e a desigualdade social gritante - e uma nova ordem internacional, responsáveis por extremar os desafios constitucionais na busca do Estado Social.

\section{2) Pano de fundo dos direitos sociais no Brasil}

Para se pensar a revolução e a dominação burguesas engendradas no país há de ter sempre em mente a questão do subdesenvolvimento ${ }^{446}$ que nada mais é do que um capitalismo dependente, articulado na dominação externa e no desenvolvimento desigual interno associação singular entre riqueza e pobreza - bem como das oscilações daí resultantes.

A correlação entre capitalismo monopolista e burguesia periférica estabelece uma "revolução" singular no contexto histórico do capitalismo, confinada aos interesses e aos valores de classe, marcados profundamente por um duplo movimento: de um lado, a exacerbação dos impulsos burgueses ${ }^{447}$ - "racionalismo acumulador e expropriativo, egoísmo e o despotismo de classe"; de outro lado, a "neutralização dos impulsos sociais", com vistas a situar e a consolidar o papel pertencente ao país em uma ordem econômica mundial previamente dada. Os extremos, sejam eles do individualismo ou da violência racional, têm uma razão de ser, na medida que o desafio dessa burguesia é posto sob a seguinte alternativa $^{448}$ : ou se realiza o crescimento econômico via modernização ou sua própria dominação é trazida à baila em face dos acontecimentos do século XX, marcados pelas crises cíclicas do capitalismo e pelo avanço do socialismo real.

Ao lado do subdesenvolvimento, caminha a "dupla articulação" entre os poderes externo e interno, que é a responsável por estabelecer, em última análise, um padrão de modernização econômica que mescla o velho - estruturas coloniais - e o novo - capitalismo e que inibe o desenvolvimento social, tendo como contrapartida a liberdade quase que infinita ao mercado. Nessa órbita, talvez, o elemento mais importante deste modelo de dominação, por mais paradoxal que possa parecer, seja justamente o arrefecimento das funções burguesas

\footnotetext{
${ }^{445} \mathrm{~A}$ fim de estabelecer um qualitativo entre os padrões de direitos sociais previstos nas diversas constituições brasileiras, vide CRUZ, Paulo Marcio. Fundamentos históricos, políticos e jurídicos da seguridade social. In: ROCHA, Daniel Machado da; SAVARIS, José Antônio (coord). Curso de Especialização em Direito Previdenciário. V. I. Curitiba: Juruá Editora, 2006, p. 70/83.

${ }^{446}$ Fernandes, Florestan. A revolução burguesa no Brasil...Op.Cit., p.349.

${ }^{447}$ Fernandes, Florestan. Ibid, p.359/360.

${ }^{448}$ Fernandes, Florestan. Ibid, p.421.
} 
clássicas, bloqueando o advento da dinamização ínsita ao regime capitalista e, por conseguinte, de um projeto de país. Isso explica, em grande monta, a exacerbação da associação entre burguesia e Estado com o primado deste sobre a sociedade civil, pois o Estado forte é a via eleita para a realização da revolução nacional em um ambiente de capitalismo tardio, surgindo, assim, como o "dínamo do poder burguês". Isso porque, nas palavras de Florestan Fernandes, a burguesia "não pode, sob o capitalismo dependente e subdesenvolvido, sustentar-se, impor-se coativamente e suplantar os conflitos de classe apoiando-se exclusivamente nos meios privados de dominação de classe e nas funções convencionais do Estado democrático burguês. (...) Na medida em que puderam tolher e unificar suas próprias reivindicações, congregando-se em torno de interesses capitalistas internos e externos comuns e articuláveis, elas puderam silenciar e excluir as outras classes da luta pelo poder estatal, conseguindo condições ideais para amolgar o Estado a seus próprios fins coletivos particularistas. (...) uma ditadura de classe explicita e institucionalizada uma eficácia que ela jamais alcançaria sob o Estado democrático- burguês convencional. " 449 Em síntese, a trajetória do país no século XX, a ser descrita abaixo, objetiva mostrar o modo pelo qual esse modelo político fora imposto visando à modernização da economia nacional, do qual, marginalmente, retiram-se resultados, senão significativos, ao menos favoráveis às demais classes sociais.

\subsection{1) O Estado novo e a democracia liberal}

De plano, é mister fazer uma breve incursão na história do Brasil no século XX até a chegada à Constituição de 1988. O ponto de partida é a revolução de 1930 que representou um ponto de descontinuidade com a lógica agrária tanto da aristocrática imperial como da república velha e alçou o país de vez à ordem capitalista internacional. Frise-se que o marco $1930^{450}$ não é representativo de uma ruptura revolucionária tal como se deu no percurso histórico tradicional da dominação burguesa. No entanto, ele teve o mérito de introduzir um incipiente embate entre as políticas de classe - de um lado a "policial" e de outro a do "dissenso". Isso porque o aparecimento e a formação da burguesia nacional como classe social aparta-se do modelo clássico, na medida que, aqui se verificou uma absorção das

\footnotetext{
${ }^{449}$ Fernandes, Florestan. A revolução burguesa no Brasil...Op.Cit., p. 358/359.

${ }^{450}$ Oliveira, Francisco de. Privatização do público, destruição, da fala e anulação da política: o totalitarismo neoliberal. In: Oliveira, Francisco de; Paoli, Maria Celia (org). Os Sentidos da democracia...Op.Cit., p. 60.
} 
oligarquias tradicionais ao "ethos burguês" em um ambiente de acelerado crescimento urbano e comercial seguido de uma industrialização incipiente.

A não ruptura é definitivamente o fato decisivo do período, a ponto da própria revolução de 1930 sinalizar, segundo a percepção de Florestan Fernandes ${ }^{451}$ que, muito embora os interesses agrário-comerciais contrapunham-se aos interesses burgueses, bem como a seu modo de ser, o processo burguês de adensamento ganhou em corpo muito antes que os interesses industriais e financeiros presentes, tanto no Estado novo como no Estado democrático liberal dos anos de 1950, viessem, de fato, a ser o interesse prevalente.

Então, se a classe dominante de outrora - oligarquia - em si não representava um problema à revolução burguesa nacional, esta se deparava com empecilhos de outra magnitude jamais vistos do ponto de vista histórico, a saber: primeiro deles, é fruto das amarras do passado - escravista e capitalismo comercial - de onde sobressai a ausência de uma verdadeira solidariedade de classe (burguesa), seja porque havia uma fragmentação local e regional muito expressiva, ou então, porque não se fazia presente, ainda, o verdadeiro empresário, industrial e financeiro. Adicione-se ao quadro um incipiente desenvolvimento urbano, uma fraqueza, qualitativa e quantitativa, da classe média e de um "baixo índice de universalidade dos processos de secularização da cultura e de racionalização do modo de compreender o mundo".

Os pontos acima listados dão a dimensão do ambiente, ${ }^{452}$ no qual se fez possível o desenvolvimento nacional, feito, basicamente, pela industrialização a partir do Estado, mais especificamente, o setor de indústria de base - energia e siderurgia.

Assim, o Estado-empresário tomou para si a responsabilidade pelo desenvolvimento de áreas que demandam altos investimentos, longo prazo de maturação, mas, que é basilar ao desenvolvimento de outros ramos industriais. Esse movimento é relevante na medida que autoriza não apenas o desenvolvimento do capital em seu todo, como também permite a transferência de parte da mais valia, aí gerada para o setor privado. Outra marca do período é o corporativismo de Estado, na qual a articulação das forças sociais se processa no interior da ordem estatal que incorpora, pela via da representação, interesses de ambas as classes. Desta forma, conjuga-se um modelo de desenvolvimento onde o Estado é o ator central, seja no campo econômico ou social.

Essa inversão da lógica clássica, com o primado do Estado sobre a sociedade, é resultado da própria debilidade da classe burguesa que se mostrou ineficaz para primeiro

\footnotetext{
${ }^{451}$ Fernandes, Florestan. A revolução burguesa no Brasil...Op.Cit.,p. 361/363.

${ }^{452}$ Coutinho, Carlos Nelson. Contra a corrente...Op. Cit., p.112/117.
} 
construir e, em seguida, alargar o consenso burguês democrático, o que impediu, assim, a absorção pelo sistema de toda série de pressões, sejam elas oriundas, tanto do interior como da oposição à ordem vigente. E mais, a única ordem possível de imperar haveria de neutralizar ou excluir as demais classes pela via da tutela ou da inércia que, no fundo, remete à lógica da ligação entre "senhor e escravo", na qual o destino daquele se realiza dentro deste. Eis aí o fundamento do populismo ${ }^{453}$ e da essência do regime republicano com o seu "presidencialismo autoritário", pautado pela cidadania excludente, cujo móbil vem das "pressões de cima para baixo", relegando as "pressões de baixo para cima" a opressão e a repressão e construindo, desta forma, um pobre consenso social, que é reproduzido nos diplomas constitucionais e legais de então.

$\mathrm{Na}$ esteira desse processo de reorganização da acumulação capitalista no Brasil implementado pelo Estado Novo, a seguridade social ${ }^{454}$ deu seus primeiros passos sob a forma de IAP (Institutos de Aposentadorias e Pensões). Estes institutos eram modalidades de entidades autárquicas vinculadas ao Estado, pelo Ministério do Trabalho, atuando sob o regime de capitalização (correspondência entre benefícios e contribuições - empregadores e empregados) e de segmentação corporativa (filiando compulsoriamente todos os membros de uma dada categoria ocupacional), recolhendo fundos e provendo determinados benefícios. Conjugava-se, assim, uma relação imediata e não simétrica entre Estado e extratos ocupacionais, na qual cada categoria depois de chancelada legalmente e, portanto, organizada em sindicato, formulava seu IAP, com regras, administração e recursos próprios.

Esse desenho de seguridade foi se expandindo fragmentariamente no período 1930/1945, incorporando novas categorias, findando por estabelecer uma dupla clivagem: a primeira - fruto do discrímen estatal, pelo critério de profissões regulamentadas, entre quem era e quem não era cidadão, na lógica da vinculação cidadania/trabalho; a segunda competição, fomentada pelo Estado (ente provedor de benefícios singulares), entre os cidadãos, ou melhor, entre as categoriais profissionais, para ver quem obtinha mais privilégios (esquema de proteção social). O quantum de benefícios atendidos estava na dependência da capacidade de reivindicação da categoria, bem como no acesso às decisões. No interior dessa última clivagem, "o resultado foi duplo: um conjunto confuso de normas operando padrões desiguais de proteção e uma clientela hierarquizada, prisioneira das mediações corporativas

\footnotetext{
${ }^{453}$ Fernandes, Florestan. A revolução burguesa no Brasil...Op.Cit.,p. 385.

${ }^{454}$ Vianna, Maria Lucia Teixeira Werneck. A americanização (perversa) da seguridade social no Brasil. Estratégias de bem-estar e políticas públicas. $2^{a}$ Ed. Rio de Janeiro: Revan: UCAM, IUPERJ, 2000, p.139/142.
} 
interpostas à barganha política e incapaz de uma atuação reivindicatória mais consistente com o objetivo de alcançar melhorias no sistema." 455

Em síntese, a história nacional, ${ }^{456}$ até esse instante, cambiou do sistema oligárquico, cuja base era eminentemente a do controle social pelo uso da força (violência privada repressiva) para a industrialização, na qual se amalgamava o crescimento econômico com repressão política sem lograr um controle social do tipo universalista, dado "o caráter excludente e discriminatório da ordem social", configurando-se, assim, uma ideologia singular - pautada pela seletividade e progressividade.

Esse padrão foi alterado, em parte, no período pós $2^{\mathrm{a}} \mathrm{GG}$ até a ditadura militar, no qual se verifica uma pueril democracia liberal ceifada em menos de duas décadas, pois a "revolução burguesa" engendrada até então no país era insuficiente frente às condições do desenvolvimento capitalista, mais particularmente, a dinamicidade social que ele produz e que leva, invariavelmente, ao desenvolvimento e a exacerbação dos antagonismos de classe, seja ela no interior da classe dominante ou desta com as classes dominadas.

Os diversos interesses em conflito ganham um contorno particular em razão da defasagem de sua institucionalização política ${ }^{457}$, o que redundava na insuficiência da própria política como caixa de ressonância das potencialidades sociais de todo tipo e que, no limite, desgastava e enfraquecia o próprio poder político burguês. No interior desse quadro de incipiente democracia, esta reverberou, de alguma forma, sobre a questão da previdência social $^{458}$, tema este que angariou relativa importância seja quando das negociações sindicais ou mesmo nas disputas político-partidárias, repercutindo no modelo de IAPs, herdado do Estado Novo que se mostrava à época insuficiente aos anseios dos desenvolvimentos econômico e político. Agora, no entanto, não se pode aqui afirmar que esse "sopro democrático" fora o responsável pelo novo esboço da seguridade social no país, há de se ter em conta, primordialmente, os "intentos modernizantes colocados em prática pelo governo desenvolvimentista de Kubitschek" ${ }^{459}$ para modificação na previdência social que se avizinhava.

No período, mais precisamente em 1960, foi aprovado após 14 anos de tramitação no Congresso Nacional a LOPS (Lei orgânica da Previdência Social) que muito embora tenha avançado na ampliação e uniformização dos benefícios concedidos, direcionando-se para uma

\footnotetext{
${ }^{455}$ Vianna, Maria Lucia Teixeira Werneck. A americanização (perversa)...Op.Cit., p. 141.

${ }^{456}$ Machado, Luis Antonio. A sociabilidade excludente. In: Sader, Emir; Gentili, Pablo (org). PósNeoliberalismo...Op.Cit.,p.135/136.

${ }^{457}$ Fernandes, Florestan. A revolução burguesa no Brasil...Op.Cit.,p.375.

458 Vianna, Maria Lucia Teixeira Werneck. A americanização (perversa)...Op.Cit., p.142.

${ }^{459}$ Vianna, Maria Lucia Teixeira Werneck. Ibid, p.159.
} 
pseudouniversalização (os trabalhadores rurais permaneciam excluídos do sistema, na medida que seu ingresso formal fora franqueado só que, no entanto, não houve qualquer menção à fonte de custeio para prover esse ingresso), na troca do regime de capitalização pelo regime financeiro de repartição simples (no qual os aportes feitos ao sistema pelos trabalhadores da ativa passam a financiar os benefícios dos inativos). Ela não foi capaz de se desvencilhar por completo do modelo populista, mais precisamente dos esquemas de pressões e acordos políticos particularizados pelo corporativismo, o que, em última análise, corroborou para acentuar e consolidar a divisão entre incluídos e excluídos, na medida que a evolução do sistema da previdência deu-se pela incorporação seletiva dos segmentos sociais no compasso da modernização econômica vivida pelo país.

Essa seletividade pode ser extraída dos dizeres de Werneck Vianna ao mencionar os "anos de grande movimentação social e emergência de novos atores no cenário político, os que findam a década de 50 e iniciam a seguinte não assistiram a nenhuma modificação efetiva no sentido de um alargamento do locus decisório na área previdenciária nem presenciaram decisões substantivas capazes de afetar as condições de vida da população como um todo através de mecanismos de proteção social. A esfera da assistência médica é emblemática. No rastro da LOPS foi criado, em 1961, o Conselho de Medicina da Previdência Social, com uma composição que revela a natureza técnica das funções que lhe eram atribuídas: os diretores dos departamentos de assistência médica dos seis IAPs, o superintendente do SAMDU e representantes do Ministério da Saúde, do Conselho Federal de Medicina e dos sindicatos médicos. Este Conselho teve um papel decisivo na forma de organização da prática médica brasileira, normatizando a estrutura hospitalar e alicerçando as relações entre os setores público e privado. Não produziu, todavia, nenhuma reorientação do atendimento médico que favorecesse à população mais pobre, que, fora da Previdência, continuou a contar apenas com o "serviço para indigentes" proporcionado por prefeituras, governos estaduais e entidades filantrópicas (com nítido caráter assistencialista, estes serviços endereçavam-se aos destituídos de qualquer direito, configurando-se como mais um instrumento da política clientelista local - norteada pelas práticas da troca de favores, da monopolização de currais eleitorais, da barganha de cargos, da mercantilização das lealdades, etc.)." 460

$\mathrm{Na}$ verdade, o desenvolvimento econômico e social do período prestou-se muito mais à afirmação da solidariedade de classe burguesa do que a qualquer noção de democracia

\footnotetext{
${ }^{460}$ Vianna, Maria Lucia Teixeira Werneck. A americanização (perversa)...Op.Cit., p.160.
} 
burguesa se consideradas três ordens de pressões políticas ${ }^{461}$, a saber: a primeira delas, da própria estrutura social do país - concentração descomunal de riqueza e poder - que engessava qualquer tipo de diálogo entre burguesia e o restante da sociedade, sem que isso colocasse na berlinda o espaço destinado a essa burguesia em um capitalismo dependente e subdesenvolvido. A segunda, a forte presença do Estado intervencionista dentro dessa sociedade que, em razão de sua força e potencial socioeconômico, mostrava-se como uma ferramenta imprescindível para a consecução dos objetivos da revolução burguesa em andamento. No entanto, esse mesmo Estado, para fins do ideário burguês, traduzia-se em verdadeira ojeriza a seus anseios de liberdade e de igualdade, caso ele desviasse sua rota para um projeto de país de verdade, vide, por exemplo, o projeto da Cepal - Celso Furtado -, escapando, assim, aos domínios de um poder burguês patrimonialista e conservador. E, a terceira forma de pressão, decorre da ordem internacional previamente dada que autoriza o desenvolvimento interno tão somente na base do estreitamento dos laços de dependência entre as economias centrais e periféricas. Entretanto, essa associação (de capitais externos e internos com o primado daquela) haveria de ter limites, sob pena de a burguesia nacional vir a ficar alijada de seu poder político e, por conseguinte, do monopólio do poder estatal, perdendo, assim, sua "base material de autoproteção, autodefesa e autoafirmação no plano das relações internacionais do sistema capitalista", transformando-se em "burguesia tampão" de cunho neocolonial.

Os três fatores acima arrolados deixam duas alternativas ao tratamento do subdesenvolvimento: ou rompe-se ou adere-se a ele definitivamente, o que põe na ordem do dia as saídas políticas, tanto da democracia como da autocracia. O caminho democrático era deveras tortuoso e dificultoso; primeiro, porque o desenvolvimento econômico cumulado com a falta de amarras políticas - instituições - sabotava a construção da solidariedade de classe burguesa e conduzia invariavelmente ao engalfinhamento pela "regra de ouro" - "aquilo que é bom para o agente individual e bom para a burguesia como um todo" ${ }^{~} 462$. Depois, porque a burguesia nacional padecia dos "dilemas da juventude", no qual os "processos naturais de diferenciação vertical e de integração horizontal da classe burguesa" estavam aquém do necessário para qualquer espécie de consertação com as demais classes sociais. Sendo assim, restava-lhe, como elemento aglutinador apenas seu "status de ser classe possuidora" o que era insuficiente de per si para capacitá-la como agente coletivo a atuar, tanto na esfera de classe como na de país. Ou seja, a alternativa democrática além de praticamente "irrealizável” fora

\footnotetext{
${ }^{461}$ Fernandes, Florestan. A revolução burguesa no Brasil...Op.Cit.,p. 376/380.

${ }^{462}$ Fernandes, Florestan. Ibid, p.389.
} 
descartada rapidamente, pois "a democracia não só é dissociada da auto-afirmação burguesa, como ela seria um tremendo obstáculo ao tipo de autoprivilegiamento que as classes burguesas se reservaram, para poder enfrentar a industrialização intensiva e a transição para o capitalismo monopolista". 463

Desse modo, sobrou para a burguesia a via da autocracia que ganhou força e intensidade quando ela finalizou seu processo de tomada de consciência (de classe) de seu espaço reservado na história pelo capitalismo desenvolvido. Esta trajetória deu-se em etapas, ${ }^{464}$ das quais podem ser elencadas: i) o desprendimento da "literatura clássica" que apregoava a possibilidade de se repetir a história, ii) o esgotamento do modelo populista, como "pacto social pseudodemocrático", que era um ponto de instabilidade e de insegurança à dominação requerida pelo poder burguês, pois, quando o populismo foi posto à prova pela amplificação dos conflitos de classe, ele mostrou toda sua limitação e sequer logrou uma "democracia burguesa fraca", iii) passagem do capitalismo concorrencial ao monopolista, expondo às elites locais aos anseios imperialistas.

Esta "reviravolta" 465 foi o substrato necessário a fundamentar a solidariedade de classe, isso porque permitiu a burguesia desprender-se das questões locais, com a condição de que não viessem a prejudicar a ordem e o desenvolvimento internacional, de onde se extraíram duas consequências relevantes para o país: i) fomento da liberdade burguesa que deriva para a exacerbação do egoísmo e da irresponsabilidade de classe; ii) passagem da sociedade "democrática ou mesmo autoritária para tornar-se abertamente totalitária e contrarrevolucionária" estabelecendo a "ditadura de classe preventiva" que tinha por propósito neutralizar "as pressões especificamente democráticas e nacionalista de setores burgueses mais ou menos radicais" e reprimir "as pressões de igualdade econômica, social e política ou de integração nacional e de mobilização de classe das massas populares. "466

E mais, a "revolução copernicana" 467 da burguesia nacional, feita com base na releitura da experiência democrático-burguesa dos países centrais, não só depurou essa burguesia de qualquer repente de nacionalismo ou de democracia representativa, como ainda acalentou a crise do poder burguês, de modo a permitir-lhe findar a revolução burguesa dentro do capitalismo dependente. Isso se fez na base da ditadura preventiva que, no fundo, representava a "associação entre autocracia burguesa e poder externo", conjugação essa que

\footnotetext{
${ }^{463}$ Fernandes, Florestan. A revolução burguesa no Brasil...Op.Cit.,p.404.

${ }^{464}$ Fernandes, Florestan. Ibid, p.364/365.

${ }^{465}$ Fernandes, Florestan. Ibid, p.368.

${ }^{466}$ Fernandes, Florestan. Ibid, p.371.

${ }^{467}$ Fernandes, Florestan. Ibid, p.370/371.
} 
potencializava em muito as possibilidades da revolução burguesa em curso no país quando se comparadas com aquelas disponíveis à burguesia local de per si.

\subsection{3) Período militar}

O golpe militar de 1964 foi a resposta final à política do dissenso levemente introduzida no país a partir dos anos 1930, haja vista a premência em se restabelecer as condições ideais para o desenvolvimento econômico acelerado - revolução burguesa possível - cujos fundamentos foram postos à prova pelas crises advindas do próprio sistema capitalista ou da eclosão do socialismo na periferia. No mais, a ditadura ${ }^{468}$ ratificou o modelo de desenvolvimento pelo Estado com o distintivo da troca do pacto populista varguista pela repressão aberta e do marcante ingresso do capital estrangeiro, estabelecendo, assim, o tripé Estado, capital nacional e capital estrangeiro, de acordo em consonância com os preceitos do último.

O Estado nacional mostrou-se como a via de eleição para compensar as deficiências estruturais do poder burguês nacional ${ }^{469}$, ao permitir, naquele instante, sua unificação e concentração, criando a solidariedade a partir do elemento comum - o fato de ser a classe possuidora -, na medida que a monopolização da cidadania era, simultaneamente, a resposta às pressões democráticas das classes dominadas, bem como a forma de autoafirmação e autoprivilegiamento da burguesia, possibilitando controle do tempo do espaço e da sociedade, fixando os ritmos do impacto da industrialização e da eclosão do capitalismo monopolista. Esse solapamento do precário regime representativo dado pela "contrarrevolução" não apenas resolve o problema imediato da crise do poder burguês, como também lhe outorga uma nova oportunidade histórica, qual seja: a aceleração da revolução burguesa.

Esse aprofundamento da relação entre poder burguês e Estado nacional resulta na acentuação das desigualdades econômicas, sociais e políticas preexistentes. E mais, ele autoriza a construção de um arcabouço institucional pautado em uma ordem social competitiva na esteira do "vir para ficar", seja pela "modernização de estruturas jurídicas $e$ políticas preexistentes, a renovação e a racionalização da maquinaria de opressão e de repressão do Estado" ${ }^{470}$, ou, ainda, pelo diálogo direto entre Estado e interesses burgueses,

\footnotetext{
${ }^{468}$ Coutinho, Carlos Nelson. Contra a corrente...Op. Cit., p.120/121.

${ }^{469}$ Fernandes, Florestan. A revolução burguesa no Brasil...Op.Cit.,p.390/391.

${ }^{470}$ Fernandes, Florestan. Ibid, p.403.
} 
tendo em vista as necessidades no tocante às questões envoltas em torno da rapidez, da segurança, da eficiência e do sigilo.

Nesse sentido, o deslocamento do espaço da política assim perpetrado tem como consequência a cisão entre as revoluções econômica e nacional dentro da revolução burguesa, fazendo do Estado a peça nuclear para a consolidação final do capitalismo na periferia da ordem mundial. Isso porque esse modelo autocrático de Estado capitalista "dá o espaço político de que elas carecem para intervir, deliberada e organizadamente, em função de suas potencialidades relativas, no curso histórico da Revolução Burguesa. (...) Sem o controle absoluto do poder, que as classes burguesas podem tirar da constituição desse Estado, seria inconcebível pensarem-se como elas conseguem apropriar-se, com tamanha segurança, da enorme parte que lhes cabe no excedente econômico nacional; ou, ainda, como elas logram dissociar, quase a seu bel-prazer, democracia, desenvolvimento capitalista e revolução nacional." $" 471$

Aliás, o Estado brasileiro ${ }^{472}$, como todo Estado capitalista, tem como elemento nuclear o domínio de interesses privados e, em especial, das diversas frações da burguesia. A singularidade do caso brasileiro é um "privatismo potencializado", porquanto no país, ao reverso das democracias liberais, desenvolveu-se "uma dominação sem hegemonia", uma vez que não havia um "consenso ativo" dos governados para uma proposta político-ideológica dos governantes. O que se processou foi a hegemonia de uma fração da classe dominante sobre as outras frações, mas não do conjunto dessa classe sobre o conjunto das classes subalternas e, desse modo, não se precisou buscar a legitimação pelo consenso e, assim, não foi necessário atender às demandas das classes dominadas que, normalmente, é materializada em políticas públicas, das quais se destacam as de seguridade social e as de educação. De fato, esse fora o modelo de Estado - uma dentre as tantas modalidades de neoabsolutismo ${ }^{473}$ - possível de surgir na periferia do capitalismo, a fim de dar conta da situação social - contraditória e anárquica - a que a burguesia local era obrigada a enfrentar.

O quadro acima indica os preceitos sob os quais se erigiu a troca do "padrão populista" pelo "padrão silêncio", sob os auspícios da exasperação do desenvolvimento capitalista brasileiro e pauta, também, o horizonte de modificações da seguridade social ${ }^{474}$ que, agora, associada a uma lógica privatizante de fundamento técnico/burocrático, fora

\footnotetext{
${ }^{471}$ Fernandes, Florestan. A revolução burguesa no Brasil...Op.Cit.,p.408.

${ }^{472}$ Coutinho, Carlos Nelson. Contra a Corrente...Op. Cit., p.126/127.

${ }^{473}$ Fernandes, Florestan. A revolução burguesa no Brasil...Op.Cit.,p.407.

${ }^{474}$ Vianna, Maria Lucia Teixeira Werneck. A americanização (perversa)...Op.Cit., p. 142/145.
} 
direcionada a um novo modelo, cunhado por Werneck Vianna de "americanização (perversa)".

No populismo de outrora, a seguridade gravitava em função de "clientelismo de horizontes limitados" - constituído por uma clientela diminuta e estratificada com acesso à cidadania - e a duras penas caminhava a uma relativa e quiçá universalização, graças ao jogo político democrático pós-1945; com o golpe militar, rompeu-se esse padrão, estabelecendo uma "abrupta universalização" (entendida para além da organização corporativa, na qual conciliava filiação obrigatória ao regime da previdência social com crescimento econômico e do emprego, sem se desvincular do seu discrímen - emprego formal), seguida da privatização do público, na esteira das seguintes alterações: adoção de critérios de mercado e de eficiência empresarial na gestão dos órgãos públicos ligados a programas sociais; a já existente "terceirização" - ampliação da rede de atendimento médico-hospitalar via contratação de entes privados; o redirecionamento do fundo público (FGTS, FAS, PIS/PASEP) para fins que não o da seguridade; a cultura do privado - abandono intencional do serviço público quer seja, primordialmente, pela insuficiência do atendimento, pela via dos convênios-empresa, dentre outras modalidades.

Sob a pecha da "modernização conservadora"475, a seguridade social avançou conjugando as necessidades do modelo econômico de acumulação - grande empresa fordista com o ranço histórico da seletividade vinculada ao emprego formal. Seu crescimento deu-se na base da diferenciação dos serviços em função da clientela atendida, na privatização dos mais rentáveis (educação, saúde e previdência, por exemplo) e na centralização e burocratização em detrimento de qualquer modalidade de participação popular. Esse tipo de expansionismo calcado na "fragmentação dos meios de consumo coletivo" mostrou-se permissivo ao ingresso do privado no sistema, o que culminou por ratificar as diferenciações de consumo, sejam elas em razão do acesso ou do custo aos bens e serviços ofertados. Também, não se pode esquecer a ajuda do Estado ao processo de privatização da seguridade por meio do mecanismo da renúncia fiscal (isenção de imposto de renda e de contribuições sociais para citar alguns).

Esta estruturação da seguridade, amalgamando interesses privados e a ausência da democracia resultou em uma dupla política social: uma voltada à " reprodução da força de trabalho contratada pelo setor monopolista"; a outra, residual para o trabalhador não integrado

\footnotetext{
${ }^{475}$ Fernandes, Ana Elizabete Simões da Mota. Cultura da crise e seguridade social...Op. Cit., p. 136/142.
} 
a esse setor, ampliando ainda mais a distância que já se desenhava no populismo entre os dois tipos de trabalhador - o assalariado/cidadão e o precarizado.

Nessa lógica, o percurso no período da seguridade pode ser ilustrado com base na narrativa de Werneck Vianna a respeito da assistência médica ${ }^{476}$. O modelo foi construído tendo em vista a formação da chamada "mercantilização da medicina" pautada em duas decisões de política social: "a compra de serviços médicos, pelo Estado, e a transferência da função provedora para a iniciativa privada", movimentos esses determinados em razão do potencial crescimento da "clientela", modulando, desta forma, os contornos da interação entre público e privado. No instante inicial - de 1967 a 1975 -, o papel do Estado como cliente maior dos serviços médicos foi decisivo, uma vez que sem ele o embrionário setor privado de saúde dificilmente "daria o salto de organização e de competitividade" em direção ao capitalismo.

Depois, em meados da década de 1970, já com o relativo desenvolvimento e autonomia do setor privado, a técnica da transferência de função do público para o privado mostrou-se o "caminho natural" para desonerar o Estado "num poderoso mecanismo de saneamento às avessas do sistema público, dele expulsando os assalariados menos pobres". Este segundo movimento, no qual os convênios-empresa se sobressaem como agentes do sistema de saúde a modular a relação entre público e privado, estabelece, segundo Werneck Vianna, o traço incontornável e irremediável de nosso processo de americanização. Por fim, no inicio dos anos de 1980, a "parceria público-privada" deu mostras de esgotamento: seja porque cumpridora de seus objetivos, a consolidação do mercado privado de saúde, ou porque do retorno incipiente da política que passou a questionar o modelo implementado pelos militares, cujo resultado final é o texto da Constituição de 1988 que reverberou ambos os anseios (da medicina de grupo e dos sanitaristas), a ponto do serviço de saúde ser reconhecido como um serviço público sem a necessidade de outorga/concessão, pois o privado retira diretamente do texto constitucional o permissivo legal à sua atividade, sem maiores ingerências do Estado, além do tradicional marco regulatório e fiscalizatório.

Da exposição vem a seguinte questão: como um Estado autocrático na ausência da democracia pôde ampliar a rede da seguridade social para além de um Estado democrático, como explicar essa contradição? Por óbvio, a resposta não pode ser exaustiva, mas em momento algum há de se perder de vista que a seguridade social essencialmente no modelo fordista de acumulação é um elemento central para o desenvolvimento do processo produtivo,

\footnotetext{
${ }^{476}$ Vianna, Maria Lucia Teixeira Werneck. A americanização (perversa)...Op.Cit., p.145/148.
} 
dos mecanismos de gestão e de reprodução da força de trabalho. Não se pode esquecer, ainda, que na ausência da democracia, as políticas sociais de Estado dirigem-se, senão exclusiva ao menos precipuamente, aos setores produtivos fundamentais da economia, cujo resultado é a clivagem incontornável da sociedade entre o trabalhador assalariado da grande empresa e os demais trabalhadores, a ponto da disseminação dos direitos sociais entre os excluídos de outrora, engendrada pelos militares, ter servido muito mais de elemento estigmatizador do que ao desenvolvimento de qualquer noção de cidadania, pois a política social fora feita em bases tão precárias e tão elementares que afastaram do sistema público os trabalhadores formais e a classe média assalariada, frutos da modernização capitalista do período. ${ }^{477}$

Assim, tomando o caso nacional a contrário sensu e concatenando o item em tela com o pretérito, é possível esboçar e adiantar uma conclusão: "a seguridade social diz respeito tanto ao movimento de valorização do capital, como, também, às conquistas das classes trabalhadoras que, ao lutarem e conquistarem meios de reprodução da própria vida, impõem ao capital e ao Estado o desenvolvimento de ações que se confrontam com os interesses imediatos da acumulação.

Não se trata de uma ação mecânica do capital e tampouco do trabalho. Na realidade, as condições gerais do processo de produção material e de reprodução social são permeadas de contradições que, em determinadas conjunturas, se transformam em necessidades de classe e objeto da prática política dos trabalhadores e do capital. Esse processo depende do grau de desenvolvimento das forças produtivas e do nível de socialização da política conquistado pelas classes trabalhadoras. ${ }^{, 478}$

Feito o parêntese em torno da seguridade, retoma-se aqui a fase final da ditadura e o inicio da transição democrática que colhem em alguma medida a parte final do parágrafo anterior, pois em que pese às tentativas da ditadura de conter e desmobilizar a sociedade civil, esta se desenvolveu durante o regime na medida que a ordem econômica e social ganhava em complexidade e contradições. A consequiência última do processo foi o ressurgimento da política e da democracia, cujo maior expoente chamou-se Constituição de 1988 nas quais as reivindicações políticas anteriores ganharam foros de direito, processo que se "pôs em xeque à repartição da riqueza", dentro da conjunta histórica possível. ${ }^{479}$

As alterações do modelo capitalista carreiam consigo o desenvolvimento da sociedade de classes, levando para o interior do Estado interesses outros que não apenas os da

\footnotetext{
${ }^{477}$ Vianna, Maria Lucia Teixeira Werneck. A americanização (perversa)...Op.Cit., p.151/152.

${ }^{478}$ Fernandes, Ana Elizabete Simões da Mota. Cultura da crise e seguridade social...Op. Cit., p. 25.

479 Oliveira, Francisco de. Privatização do público, destruição, da fala e anulação da política: o totalitarismo neoliberal. In: Oliveira, Francisco de; Paoli, Maria Célia (org). Os Sentidos da democracia...Op.Cit., p. 65.
} 
classe dominante, e o Estado, agora, tem de encontrar um ponto de equilíbrio de modo a não pôr em risco o núcleo essencial do capitalismo - propriedade dos meios de produção. Aqui são colocados em cheque os pilares do modelo autocrático bem como sua própria “eternização", pois "as classes burguesas, apesar de tudo, levaram água de mais ao moinho e que acabarão submergindo no processo político que desencadearam, ao associar aceleração do desenvolvimento capitalista com a autocratização da ordem social competitiva". 480

No final de todo esse longo processo de estabilização da ordem nacional, iniciado em 1964, a sociedade civil mais do que reivindicar e apresentar sua fatura, na base de apresentação de demandas, foi ela quem assumiu o "núcleo revolucionário dos dinamismos políticos do poder burguês", como resposta ao bloqueio imposto abrupta e prematuramente pela contrarrevolução da década de 1960, as relações de classe. Se essa mesma contrarrevolução ceifou o dinamismo da política burguesa, "a largo prazo, substituiu-os por outros, que deveriam crescer e funcionar no contexto político imediato, criado pela instauração de uma ordem social competitiva regenerada e submetida aos controles revolucionários e institucionais operantes nessa nova ordem" a ponto do arrefecimento do dinamismo da estrutura de classes achar aí "uma compensação política imprevista e decisiva". 481

Tanto, assim, que a ditadura perdeu o controle do processo de abertura "pelo alto", culminado em uma ruptura progressiva e negociada com o regime que saia de cena. Esse tipo de transição, combinando processos de abertura "pelo alto" e "de baixo", foi deletéria ao país, porquanto não produziu uma ruptura com as características elementares (autoritarismo e a exclusão) do sistema político vigente ${ }^{482}$. Dois traços ${ }^{483}$ são marcantes para continuidade que se avizinhava: primeiro, o fato de a revolução burguesa ter sido produto das classes médias; depois, o modus operandi da abertura da ditadura que se fez pela "democracia de cooptação", que apenas exacerba as contradições sociais, porquanto sua margem de manobra é estreita, pois seus limites são dados pelas deficiências estruturais da sociedade - concentração de renda e de poder - de modo a alijar qualquer hipótese de democracia verdadeira para o país.

Adentrando na especificidade da transição ${ }^{484}$ do regime ditatorial para o democrático, verificam-se duas peculiaridades no processo: i) o tipo de consertaçao social acima introduzida, ii) resultado do processo - institucionalização da democracia, mas não sua

\footnotetext{
${ }^{480}$ Fernandes, Florestan. A revolução burguesa no Brasil...Op.Cit.,p.424.

${ }^{481}$ Fernandes, Florestan. Ibid, p.414.

${ }^{482}$ Coutinho, Carlos Nelson. Contra a corrente...Op. Cit., p.132/133.

${ }^{483}$ Fernandes, Florestan. A revolução burguesa no Brasil...Op.Cit.,p.422.

${ }^{484}$ Weffort, Francisco Correia. Qual democracia? São Paulo: Companhia das Letras, 1992, p. 113/119.
} 
consolidação em virtude da ausência das reformas econômica e social, a ser melhor trabalhado no item subsequente. Quanto ao primeiro, o padrão da transição junge liberalização de cima - fruto as fissuras do poder e democratização de baixo - pressão por maior participação num contexto de crise e de estagnação econômica, dada pela agonia do "modelo de desenvolvimento" cumulado com carência de liberdade política.

Nesse ambiente de penúria, toma corpo a legitimidade da ideia de sobrevivência em detrimento de uma nova concepção de Estado e de sociedade - uma nova visão de mundo. Somado, ainda, ao padrão da sociedade brasileira de então - movimentos sociais, tende-se a exacerbação do processo de fragmentação, no qual cada grupo de interesse organizado procura satisfazer suas demandas - redundando na "balcanização da sociedade" de ambos os lados, seja do lado do capital ou do trabalho. Esta tessitura social dá uma amostra do porquê dos "movimentos democráticos terem sido mais eficientes na oposição do que no governo. (...) Até agora, nossas sociedades têm sido mais capaz de se opor a um governo (refiro-me às ditaduras) do que de construir um governo democrático." ${ }^{485}$

A transição nacional, combinando continuísmo e conservação, inaugura um regime misto de instituições democráticas e autoritárias com a permanência ou conversão de lideranças e correlatos (partidos, imprensa, escolas, sindicatos, etc...) na passagem de um regime ao outro. Estas características são relevantes não apenas à compreensão do porvir, como também da consolidação do modelo democrático, pautado nos primados do executivo sobre o legislativo e do Estado sobre a sociedade. Sendo assim, o problema imediato desse modelo de transição é que ele aproxima o processo de formação do Estado - em que se salienta a institucionalização da violência privada - do processo de democratização, em que é relevante a institucionalização do conflito privado.

Essa equiparação é visível no momento em que a transição lega uma definição de democracia aquém daquela ofertada por liberais do quilate de Bobbio e Tocqueville. Isso porque democracia política tem por pressuposto uma igualdade social mínima entre os indivíduos de per si - igualdade de status e de consideração: oportunidade de um indivíduo ser tratado como tal pelos outros em contraponto às tendências aristocráticas de outrora. Essa condição é basilar para o funcionamento da democracia política e que não se faz presente em sociedades cuja desigualdade social é o traço distintivo.

Apesar da ambiência política não muito alentadora somada ao quadro de crise econômica internacional e nacional (que conjugava fatores, tais como: os impactos das

\footnotetext{
${ }^{485}$ Weffort, Francisco Correia. Qual democracia?...Op.Cit.,p.113.
} 
mudanças na ordem econômica mundial, da reestruturação produtiva e da rearticulação da burguesia internacional, visando a reestruturar sua própria hegemonia; todos a repercutir no país, imediatamente, pela retração da produção e do mercado interno, e depois pela necessidade de se "achar uma saída", saída essa já dada e ainda não implementada, a fim de fazer frente à nova competitividade internacional), é inegável que os anos de 1980 foram uma década profícua ao país, haja vista seu resultado ${ }^{486}$ : institucionalização de benefícios e de políticas de proteção social advindas da pressão organizada dos trabalhadores, muitas delas via sindicatos, como ator importante para o avanço e a consolidação da "fordicização precária" iniciada pelos militares nas décadas anteriores.

Observa-se que isso não excluir os outros participantes da constituinte de 1986/1988 que outorgaram ao texto constitucional um novo conceito para a seguridade social, com outras fontes de custeio, melhoria e universalização dos benefícios e serviços. Dentre os participantes da cena política nacional podem ser posicionados: de um lado - partidos políticos (os de oposição foram à caixa de ressonância dos interesses dos trabalhadores como um todo para além do mero corporativismo, e no caso da seguridade, "pode-se afirmar, pelo menos em tese, que o pressuposto da prática do partido, como dissolvedor de interesses econômico-corporativos e organizador de uma vontade coletiva parece ter acontecido" ${ }^{487}$ ), sindicatos (tem-se que fazer uma mea-culpa, na medida que sua atuação foi mais significativa para o avanço do salário indireto como medida de proteção social no âmbito das empresas do que para a consolidação da seguridade como modelo de política pública) e movimentos sociais (atores relevantes para a descentralização das políticas sociais e seu deslocamento para os municípios).

A atuação (fragmentada) das classes dominadas não lhe permitiu concatenar os interesses imediatos com os objetivos coletivos e globais, o que iria trazer implicações já no início dos anos de 1990. De outro, os empresários (o ambiente não só serviu de inflexão e de aniquilamento do projeto político-histórico tradicional, como serviu também de ensaio para construir seu novo projeto - hegemonia incorporando reivindicações dos trabalhadores em três esferas: nas relações de produção, no arcabouço institucional do Estado e na venda do seu ethos). Ou seja, tem aqui, sem sombra de dúvida, o traço distintivo da década, quando comparado à quase que a totalidade da história nacional, na medida que o diálogo e o atendimento pela burguesia de reivindicações da outras classes dominadas se fizeram valer em função da nova correlação de forças ali presentes.

\footnotetext{
${ }^{486}$ Fernandes, Ana Elizabete Simões da Mota. Cultura da crise e seguridade social...Op. Cit., p. 149/156.

${ }^{487}$ Fernandes, Ana Elizabete Simões da Mota. Ibid, p. 153.
} 
A mesma década é representativa da mudança de padrão comportamental da burguesia nacional, pois, se antes na esteira da imposição pelo alto, ela se valeu quase que com exclusividade do Estado para fazer prevalecer seus interesses; essa mesma atitude, conforme antes visto, teve um preço para essa mesma burguesia, qual seja: o fato de não ter se constituído na classe dirigente nacional. No entanto, agora ela necessita se reinventar e "para construir seu novo projeto - marcado pelas necessidades de pactos de classe - estão descartadas estratégias pontuais e situacionais. Para se tornar hegemônica, ela necessita realizar sua reforma intelectual e moral, imprescindível ao desenvolvimento do processo de socialização cultural do seu ideário de classe, que se pretende nacional. (...) Nesses termos, para realizar as mudanças no sistema de seguridade social, como parte do projeto de reformas necessárias ao enfrentamento da crise, a burguesia carece mobilizar o consentimento ativo da classe subalterna em torno do reordenamento do seu projeto social. ${ }^{488}$

Por fim, é preciso dizer, de maneira peremptória, que os avanços da década de 1980 não foram suficientes para realizar uma reforma econômica e social no país a ponto de desarmar o arcabouço herdado na seguridade social, ou seja, o perfil da privatização dos serviços sociais - saúde e previdência - ele não apenas sobreviveu como ainda alçou patamares constitucionais, deixando viva a base sobre a qual o neoliberalismo iria propagar suas ideias - "privatização e a emergência do cidadão consumidor". 489

Nesse campo, não se podem negar as consequências da fordicização das relações de trabalho nos anos de 1980 - os acordos entre grandes empresas e grandes sindicatos - para a ratificação do perfil da seguridade social antes esboçado pelos militares. Isso porque o processo de cidadania fordista desenvolvido ao longo da década - da fábrica para o conjunto da sociedade quando de sua institucionalização pelo Estado - não foi capaz de romper com a tendência antes desenhada do sistema de seguridade, no qual se verificou um imbricamento das relações entre o Estado e o setor privado, lucrativo ou não, bem como o padrão de diferenciação de consumo dos serviços sociais, critério para classificar o trabalhador em consumidor ou em assistido ${ }^{490}$. Alguns fatores ${ }^{491}$ podem ser listados a título de ilustração desse não rompimento, tendo por pano de fundo a correlação existente, direta e imediata, entre seguridade e padrão de acumulação e a questão política acima trazida.

\footnotetext{
${ }^{488}$ Fernandes, Ana Elizabete Simões da Mota. Cultura da crise e seguridade social...Op. Cit., p. 149.

${ }^{489}$ Fernandes, Ana Elizabete Simões da Mota. Ibid, p. 44.

${ }^{490}$ Fernandes, Ana Elizabete Simões da Mota. Ibid, p. 165.

${ }^{491}$ Fernandes, Ana Elizabete Simões da Mota. Ibid, p. 170/180.
} 
Foi dito antes que o movimento sindical nos anos de 1980 contribuiu para o desenvolvimento da seguridade social, mas, ao mesmo tempo, os efeitos de sua atuação foram mais incisivos em alguns setores e em algumas empresas sob a forma de salários indiretos. Esse é um ponto relevante sob o qual vale à pena deter-se nesse momento do trabalho, pois o fato não passa incólume a seguridade social. As análises de Ana Elizabete Simões da Mota Fernandes detectaram na prática sindical uma ambiguidade, dada em função da chamada "democracia industrial" que opera em favor da transformação das demandas dos trabalhadores em novos direitos via contratos coletivos de trabalho; ou então da própria história nacional de falência e de sucateamento das políticas públicas que "naturalmente" deslocam as demandas dos trabalhadores para serem supridas pelo privado, ou ainda, da atuação propriamente dita dos sindicatos a fomentar e a consolidar um verdadeiro "Welfare no âmbito de algumas empresas", na medida que as perdas salariais eram repostas por salários indiretos (consumo de bens e serviços).

Nos idos dos anos de 1970, os sindicatos tiveram o mérito de romper com o arbítrio e com a pedagogia da assistência empresarial em favor da negociação pelo contrato coletivo do trabalho; essa marca ao transcender o ambiente das empresas foi ao encontro não só do perfil da seguridade social que vinha sendo traçado (associação do privado com o público), como também do desenho da própria sociedade brasileira - divisão entre trabalhador/cidadão e o trabalhador/assistido, e daí seu ranço ambíguo, pois "mesmo considerando o fato de o movimento sindical vir estrategicamente apoiando as lutas coletivas em defesa da oferta de políticas públicas, não há dúvidas de que ele, ao negociar com as empresas os serviços privados, contraditoriamente, fortalece as diferenciações de consumo entre os trabalhadores, em função da sua inserção formal no mercado de trabalho". 492

E mais, a atuação do movimento sindical (de um lado sustentando o discurso das teses publicistas e de outro, sua práxis é segmentadora e exclusivista, vindo a obstar o desenvolvimento de políticas públicas arraigadas na solidariedade), terminou por ratificar, involuntariamente, um perfil da seguridade social bem ao gosto do pensamento neoliberal, corporificado na esteira da mudança do padrão de acumulação capitalista.

Não se quer aqui situar os sindicatos, como o grande responsável pelo fracasso até aqui da Constituição de 1988, longe disso, o que se objetiva é mostrar que no caldo de uma mudança estrutural fundamental do sistema capitalista, somado a uma conjuntura econômica e política (na qual se faz presente desemprego, baixos salários, inflação, ausência de tradição

\footnotetext{
${ }^{492}$ Fernandes, Ana Elizabete Simões da Mota. Cultura da crise e seguridade social...Op. Cit., p. 173.
} 
política, dentre outras vicissitudes), as práticas de ambas as classes refletem e redefinem a seguridade social brasileira, vindo, no caso, a referendar seu histórico de "americanização perversa".

Desse modo, pode-se fazer coro a conclusão de Ana Elizabete Simões da Mota Fernandes, na medida que "essas mudanças (da seguridade social) surgem no contexto das modernas práticas de gestão do trabalho, fortemente marcadas pelas necessidades técnicas da produção e repercutem nas formas de relação entre capital e trabalho no interior das unidades de produção e na sociedade em geral. É, por isso, que as reivindicações dos trabalhadores das grandes empresas, por serviços sociais, interferem diretamente nas tendências da seguridade social no Brasil. Não se trata de uma demanda produzida espontaneamente, mas de uma demanda formada com base num conjunto de contradições, permitindo que o capital também se beneficie daquela estratégia sindical."493

Em suma, em que pese os avanços concretos da Constituição para um país como o Brasil, não se pode negar que essa mesma Constituição, ${ }^{494}$ não foi capaz de obstar e nem de ceifar o processo de americanização da seguridade social, o que poderia dar ensejo ao inicio da implantação de um modelo de Estado social no país. Também não se pode equiparar esse processo de americanização a uma privatização pura e simples; no Brasil, encontram-se outras distorções quando se comparado ao sistema americano: uma delas é a própria "seletividade do setor público" na medida que o sistema, por exemplo, de saúde é detentor de alguns serviços de excelência (tratamentos que requerem longo prazo ou grande complexidade) cujo acesso é seletivamente franqueado ficando à margem a grande massa. Depois, o próprio arcabouço regulatório do sistema é recente - dos anos de 1990 - bem como a aplicação do CDC para essa modalidade de serviços.

Por último, o perfil de atendimento do setor privado no país não cobre mais do que $20 \%$ da população; nos EUA, o quadro se inverte: o setor privado responde por $80 \%$ do contingente populacional. Estas ordens de consideração estão em linha com o pensamento de Faleiros quando afirma que a seguridade social tem consigo uma peculiaridade perversa, não só em face do modus operandi de seu financiamento, como também do fato de que parte de seus recursos acabam sendo revertidos para os serviços privados (vide a penetração de entidades privadas $-3^{\circ}$ setor - em áreas sociais sob as mais diversas formas - Organizações Sociais ou OSCIP, medicina de grupo, universidades privadas, etc...) de modo a montar um "complexo socioestatal-empresarial-financeiro" com três pilares centrais: "i) uma

\footnotetext{
${ }^{493}$ Fernandes, Ana Elizabete Simões da Mota. Cultura da crise e seguridade social...Op. Cit., p. 180.

${ }^{494}$ Vianna, Maria Lucia Teixeira Werneck. A americanização (perversa)...Op.Cit., p.150/152.
} 


\section{socialização dos custos, ii) privatização dos lucros, iii) elitização ou exclusão das massas no}

acesso aos serviços mais avançados, reproduzindo as desigualdades. " 495

${ }^{495}$ Faleiros, Vicente de Paula. A Política Social do Estado Capitalista...Op. Cit., p.69.

Corroborando com a argumentação acima vide: Murilo Fahel, num trabalho intitulado Desigualdades em saúde por estratos ocupacionais no Brasil: análise comparada entre 1998 e 2003, desenvolveu um estudo a respeito do acesso aos serviços de saúde com base nos dados da PNAD de 1998 e 2003, o qual ratifica a insuficiência do modelo constitucional de saúde quando o assunto é a reversão do antigo padrão assistencial corporativoestratificado herdado pelo Estado. Os resultados apontam uma estratificação do acesso aos serviços de saúde quando se comparam os trabalhadores formais e informais e, os servidores públicos e trabalhadores privados.

O SUS, em apertada síntese, propugna por ser um modelo de natureza preventiva voltado para o social, envolvendo as três esferas de governo - União, estados e municípios com foco nesse último, conjugando um sistema dual público-privado, visando justamente o acesso universal à saúde à população brasileira. Na contra mão do modelo desenhado na Constituição de 1988 e dos avanços obtidos em matéria de expansão e da universalização dos serviços de saúde pós-1988, o estudo indica a persistência da velha lógica de proteção social atrelado a formalização/assalariamento, gerando acesso diferenciado entre os diferentes estratos ocupacionais.

$\mathrm{Na}$ linha das literaturas internacional e nacional na área da saúde a indicar que a desigualdade na utilização dos serviços de saúde é uma das facetas da desigualdade socioeconômica, o estudo mostrou: i) expansão no número médio de consultas em todas as camadas sociais se comparados os dados de 1998 com os dados de 2003 da PNAD (de 2,1 para 2,4 consultas por individuo na faixa etária entre 15 e 64 anos); ii) maior segmentação quanto à probabilidade de acesso aos serviços de saúde quando se compara o trabalhador formal ao informal. Em 1998, as chances do trabalhador formal em realizar uma consulta médica eram $29,81 \%$ maiores que as do informal, e, em 2003, essa chance aumentou para 35,97\%; iii) além da estratificação no acesso dado em função da condição de formalidade, há, ainda, a desigualdade no acesso quando se compara os trabalhadores da área privada com os servidores públicos. Se em 1998, as chances do servidor público em realizar uma consulta eram 6,53\% maiores que os trabalhadores privados; em 2003, essa probabilidade avançou para a casa dos 9,4\%.

Os resultados colhidos pelo estudo de Fahel indicam dois nortes: i) na esteira da constatação genérica, a qual correlaciona direta e imediatamente a desigualdade social a desigualdade no acesso à saúde; ii) a constatação de que a condição de pertencimento a um estrato ocupacional, seja ele o público ou o privado formal, outorga maiores possibilidades de acesso aos serviços de saúde. A relevância do último resultado reside justamente no fato de que o modelo de acesso universal propugnado pelo SUS, em 1998, não foi capaz de romper com o modelo anterior assentado na condição de formalidade do trabalhador.

Fahel, Murilo Cássio Xavier. Desigualdades em saúde por estratos ocupacionais no Brasil: análise comparada entre 1998 e 2003. Disponível em: http://www.eg.fjp.mg.gov.br/index.php/publicacoes/textos-paradiscussao/139-textos-publicados-em-2009/997-desigualdades-em-saude-por-estratos-ocupacionais-no-brasilanalise-comparada-entre-1998-e-2003. Acessado em 04/12/09.

Outro artigo de autoria de Marislei Nishijima, Geraldo Biasoto Junior e Denise Cavallini Cyrillo investiga de maneira indireta - feita a partir de conclusões de profissionais da área da economia da saúde das universidades (Unicamp, UFRJ), da OPAS (Organização Pan-Americana de Saúde), de entrevistas com profissionais da ANS pelo convênio "Informações e Análises Econômicas sobre o Setor de Saúde Suplementar" firmado com o Ministério da Saúde - as possibilidades de acesso da população de baixa renda aos bens públicos de saúde de alta complexidade oferecidos pelo setor público.

O trabalho aborda diversos assuntos, dentre eles: a interação entre os sistemas público e privado de saúde; os problemas oriundos da informação assimétrica existente no mercado de seguro saúde; as condições de operacionalidade das seguradoras de saúde e de suas prestadoras de serviço antes da regulação impingida ao setor pelo governo. Para os limites dessa dissertação, é relevante a interação traçada pelo artigo entre o público e o privado em matéria de saúde, depreendendo-se que "o setor privado de cuidados médicos no Brasil, embora tenha um caráter de suplemento, tende a ofertar bens de saúde de alta complexidade em quantidades além do ótimo socialmente desejado, causando problemas de eficiência econômica e de distribuição para consumo destes bens de alta complexidade pelo setor público. Isso ocorre porque o setor não arca com os custos reais desses tratamentos ofertados na forma de seguros (planos) de saúde, uma vez que utiliza a capacidade produtiva do SUS sem o devido repasse dos pagamentos dos pacientes privado".

O fenômeno em matéria de tratamento de alta complexidade se processa, em apertada síntese, da seguinte forma: a rede privada não dispõe ou possui uma escassa capacidade para atender as demandas de alta complexidade, isso porque: i) ela se vale de grandes instituições, públicas ou financiadas pelo setor público, de excelência nesse tipo de tratamento; ii) o relevante da pesquisa de ponta em matéria de medicina é financiada pelo setor público, vide, por exemplo, a formação do capital humano; iii) SUS ainda que em volume insuficiente para atender a demanda total por bens de alta complexidade, ele apresenta uma capacidade produtiva maior desses bens se comparado com o setor privado. Ao arcabouço acima, adicione-se o fato de que as empresas privadas, como 


\subsection{4) Período 1990 até hoje}

De plano, a herança acima não resolvida fez se presente na década de 1990, que inaugurou juridicamente um Estado de Bem Estar Social solapado ao longo do período sob o discurso da ineficácia das normas constitucionais quer seja pela norma programática ou pela reserva do possível. Some-se ao descompasso político, o legado militar de atuação estatal que resultou em um primeiro momento na dívida externa nos anos de 1980. Problema esse convertido em divida interna nos anos de 1990, possibilitando, assim, a abertura do espaço necessário à associação da despesa pública e, em particular, o gasto social à falência do Estado $^{496}$.

A questão primeira que se põe é: como o projeto neoliberal ganhou força no país, vindo a se tornar dominante ou até mesmo hegemônico? Não se pôde importar o discurso do esgotamento do modelo do Welfare nem da solução neoliberal para o contexto local pelo simples fato do país não ter galgado a universalização dos direitos sociais, nem ter um elevado de gasto público com as políticas sociais ou muito menos ser detentor de um padrão de regulação estatal condizente com o dos países de capitalismo desenvolvido.

Nesse sentido, Ana Elizabete Simões da Mota Fernandes ${ }^{497}$, apoiada no pensamento de Gramsci em "Americanismo e fordismo", atualizado por Buci-Glucksmann, responde à indagação sob o argumento de que nos anos de 1980 estabeleceu-se uma nova correlação de forças na sociedade brasileira, com vitórias para a classe trabalhadora, mas que também serviu de base para a burguesia construir sua hegemonia pela substituição das demandas dos

regra, não ressarcem o SUS pelo uso e tratamento dado a seu segurador por duas razões centrais: i) questões operacionais de cobrança, ii) impossibilidade legal de se efetuar a cobrança das empresas privadas, uma vez que a saúde com assento constitucional é ali definido como um direito de todos e dever do Estado, ensejando disputas nos tribunais entre as operadoras privadas e o Estado.

Essa conjugação de fatores - cuja centralidade está no fato de que o setor privado vale-se do público sem qualquer custo - redunda em dois níveis de resultado. Pensando na interação entre o público e o privado, verifica-se uma vantagem imensurável para o este, na medida em que além de não diminuir os custos de produção do setor público e de não desonerar sua capacidade produtiva dos bens de alta complexidade, gera ainda "uma externalidade negativa na produção do setor privado sobre o setor publico de saúde". Sob ótica do fator renda na população, verifica-se que aqueles de maior renda, portanto, consumidores de planos privados de saúde recebem com maior presteza e agilidade o tratamento de alta complexidade quando comparados com a parcela mais pobre da população, pois ele ao ser transferido de maneira quase que imediata ao setor público, termina por furar a fila de espera, passando a frente de quem não tem plano de saúde privado, o que finda em penalizar o acesso dos mais pobres aos bens públicos de saúde de alta complexidade.

Nishijima, Marislei; Biasoto Júnior, Geraldo; Cyrillo, Denise Cavallini. Análise econômica da interação entre saúde pública e privada no Brasil: tratamentos de alta complexidade. Disponível em: http://www.anpec.org.br/encontro2006/artigos/A06A107.pdf. Acessado em 27/09/09.

${ }^{496}$ Oliveira, Francisco de. Privatização do público, destruição, da fala e anulação da política: o totalitarismo neoliberal. In: Oliveira, Francisco de; Paoli, Maria Celia (org). Os Sentidos da democracia...Op.Cit., p. 67.

${ }^{497}$ Fernandes, Ana Elizabete Simões da Mota. Cultura da crise e seguridade social...Op. Cit., p. 163. 
trabalhadores como exigência de classe pela ideia de que a crise econômica afeta a todos, e para superá-la é preciso a colaboração de todos.

Nesse contexto, o tratamento da crise econômica para um país periférico, como é o caso do Brasil, haveria de se pautar pela adequação do modelo de seguridade social a uma realidade na qual se privilegie uma nova forma de seletividade: a intraclasse, pois para os países da América Latina o receituário de acordo com as instituições internacionais passa por "estabelecer sistemas de previdência para atender à população de idade avançada e de poucos recursos, que requer subsídios fiscais, e apoiar e incentivar as formas de poupança (...) pelas camadas média e alta renda com vistas para a sua autoproteção, de tal forma que contribuam pata sua própria seguridade social, impulsionando, por exemplo, diferentes esquemas de poupança contratual ${ }^{\text {,498 }}$.

Ou seja, o discurso do grande capital gravita em torno da cultura política da crise, seu modus operandi pauta-se na criação e na busca do consenso entre as classes, advogando a premência do tratamento da pobreza pelos programas assistenciais, ao mesmo tempo em que prega a necessidade da privatização de alguns serviços da seguridade - previdência e saúde, de modo a ter como resultado final um Estado Mínimo, bem como reduzir os impactos sociais dos ajustes econômicos neoliberais. Sendo assim, a hipótese defendida por Ana Elizabete Simões da Mota Fernandes é bem plausível e, assim, pode ser resumida: "o processo vem sendo molecularmente trabalhado pela burguesia, na medida em que as classes dominantes tentam socializar com as classes trabalhadoras um suposto dilema da justiça e equidade capitalistas, como sendo uma problemática dos assalariados, agora reconceituados como cidadãos proprietários consumidores elou cidadãos pobres e assistidos. Aliás, uma precondição para o desenvolvimento do que nomeamos de movimento sincrônico de assistencialização/privatização da seguridade social". 499

Em outras palavras, a crise dos anos de 1980 é a base material sob a qual se levanta o discurso neoliberal a fim de que o Capital possa se apropriar com as devidas adaptações do discurso do outro, outorgando, assim, um novo tratamento à questão social, assentada agora na cultura da solidariedade social que desloca a luta dos trabalhadores para o enfrentamento da crise de modo que todos, sem exceção, são responsáveis pela solução do problema, estatuindo uma espécie de solidariedade interclasses.

Isso é claramente perceptível no movimento da seguridade social cuja efetivação é transferida do patamar constitucional para o campo do orçamento fiscal e, por conseguinte, da

\footnotetext{
${ }^{498}$ Fernandes, Ana Elizabete Simões da Mota. Cultura da crise e seguridade social...Op. Cit., p. 146.

${ }^{499}$ Fernandes, Ana Elizabete Simões da Mota. Ibid, p. 147.
} 
governabilidade a exigir a aprovação de toda a sociedade. Desse modo, sob o argumento de que a crise econômica afeta a todos (na verdade, é problema/necessidade eminentemente burguesa para reorganizar seu processo de acumulação), e todos devem contribuir com sua cota de sacrifícios, abrindo, desta forma, o espectro para o pensamento neoliberal florescer num campo não teorizado inicialmente por ele, mas que se justifica sob a difusão do "conservadorismo do mal menor, das saídas possíveis, expresso na idéia de que é melhor dar mais a quem tem menos, com o objetivo de estimular a solidariedade como expressão material, ideológica e cultural da naturalização da desigualdade social". 500

Vê-se, aqui, encorpado o receituário neoliberal adaptado a países periféricos que sem perder seu norte - reestruturação do sistema capitalista - objetivamente propugna por: i) no campo político, pelo senso comum dirigido pela pequena política em um jogo democrático aos moldes do bonapartismo, ii) na seara econômica, pela ética do privatismo e da prescindibilidade do público, na medida que reina a unanimidade da ideia de que a existência do público depende da do privado, performando-se, desse modo, "a forma moderna de sustentação da crise do capital privado." 501

Acentua-se, assim, a oposição entre Estado e mercado ${ }^{502}$ seja pelo discurso da eficiência deste ou por atos concretos de desregulamentações e privatizações de empresas e de serviços públicos rentáveis, cujo resultado final altera decisivamente a correlação de forças em prol do mercado, fato esse visto pela supremacia do econômico, pela redução do controle público, facilitando a atuação do setor privado.

O neoliberalismo tem, ainda, um viés subjetivo que corresponde a um "processo de subjetivação da experiência burguesa" que é em grande monta "uma experiência de transcendência dos próprios âmbitos de classe" - homem privado como base social ${ }^{503}$. Proposta essa que em um país individualista, como o Brasil, caracterizado pelo histórico de primado do Estado em face da organização social, erige-se a "condição de dogma sagrado". Esse processo de individualização, no fundo, remonta à sociabilidade do tipo hobessiana ${ }^{504}$ que não autoriza a formação de identidades coletivas minimamente estáveis, conduzindo à objetivação do outro.

\footnotetext{
${ }^{500}$ Fernandes, Ana Elizabete Simões da Mota. Cultura da crise e seguridade social...Op. Cit., p. 222.

${ }^{501}$ Oliveira, Francisco de. Privatização do público, destruição, da fala e anulação da política: o totalitarismo neoliberal. In: Oliveira, Francisco de; Paoli, Maria Célia (org). Os Sentidos da democracia...Op.Cit., p. 68.

${ }^{502}$ Borón, Atilio. A sociedade civil depois do dilúvio neoliberal. (In) Sader, Emir; Gentili, Pablo (org). Op. Cit., p. $77 / 79$.

503 Oliveira, Francisco de. Ibid, p. 70.

${ }^{504}$ Machado, Luiz Antonio. A sociabilidade excludente. In: Sader, Emir; Gentili, Pablo (org). Pósneoliberalismo...Op.Cit.,p. 137.
} 
Em suma, os dois espectros constituem a razão de ser da privatização do público, na qual "a crise do Estado, vista do ângulo de sua impotência para deter, realmente, o monopólio da violência legal, é uma conseqüência, objetivamente, de sua dilapidação financeira, e, subjetivamente, da falsa consciência da desnecessidade do público pelas burguesias e seus afiliados". ${ }^{505}$ Tal conjunção permite ao neoliberalismo romper com toda a tradição da ciência política, conforme o interesse privado prescinde de universalização e de abstração em razão do nível de dominação presente hoje na sociedade. Eis aí a faceta verdadeira do neoliberalismo: a do "totalitarismo", fruto da destruição de qualquer possibilidade política perpetrada pelo esvaziamento da esfera pública que havia aparecido no país na década de 1980. De fato, uma maneira de governar voltada ao atendimento dos interesses privados, excluindo o conflito e a própria possibilidade de acordos públicos amplos, tornando prescindível a política democrática, "a inevitável privatização dos negócios públicos torna possível permite o exercício de um poder sem partilha, anula as outras falas, desmoraliza as demandas da sociedade e força o seu desaparecimento político; também a burguesia se amesquinha em sua promiscuidade com o Estado, em sua identificação com o governo com a forma de operar da administração empresarial privada, em seu estilo de vida onde o desenraizamanto público fecha qualquer sensibilidade para o outro. Em resumo, estamos no quase disfarçado totalitarismo neoliberal", 506 que é um "liberalismo requentado" na qual há uma dissolução da vida política.

O quadro contraditório feito de avanços e recuos do tratamento da questão social, ora permeável, ora impermeável às demandas das classes subalternas reflete no desenho da seguridade $\operatorname{social}^{507}$, acentuando o pensamento privatista e a formação do cidadão consumidor. Em linha com a proposta neoliberal de "cunho universalizante" desde que respeitados os pilares do mercado e da solidariedade entre as classes antagônicas, a seguridade social passa a associar mercantilização com assistencialização.

É importante frisar que esta proposta segue os anseios expansionistas do capital que trabalha na incorporação seletiva das demandas dos trabalhadores. Ela se materializa pela apropriação do fundo público, seja como forma de reprodução dos investimentos privados, “transformando a previdência e a saúde em negócios rentáveis, isto é, em mercadorias ou, ainda, captar recursos dos trabalhadores valendo-se dos fundos de pensão ou dos seguros

\footnotetext{
505 Oliveira, Francisco de. Privatização do público, destruição, da fala e anulação da política: o totalitarismo neoliberal. In: Oliveira, Francisco de; Paoli, Maria Célia (org). Os Sentidos da democracia...Op.Cit., p. 73.

${ }^{506}$ Paoli, Maria Célia. Apresentação e Introdução. Ibid, p. 13.

${ }^{507}$ Fernandes, Ana Elizabete Simões da Mota. Cultura da crise e seguridade social...Op. Cit., p. 219/230.
} 
privados ${ }^{\text {"508 }}$. E o último, a previdência complementar, ela se transforma na menina dos olhos do capital, na medida que é fonte de recursos para suprir as necessidades do capital quer na sua modalidade industrial ou financeira pela via mercado de capitais.

Esse ponto à semelhança do item pretérito mostra-se como um elemento importante a balizar a mudança do padrão produtivo, na medida que os trabalhadores são agora convidados a se tornarem sócios minoritários do capital, dado que a fragmentação da previdência - básica e da complementar - possibilita vultosos aportes dos trabalhadores à previdência privada, recursos esses relevantes para financiar, na modalidade de fundos de pensão, o novo processo de acumulação do capital.

Em suma, as estratégias de combate à crise econômica tomam corpo em duas linhas convergentes: i) na modalidade de Estado mínimo - sob o discurso de sua ineficiência, ele deve se limitar a regular os agentes econômicos ou, no máximo, a tratar a pobreza de forma focalizada pela assistência social restrita aos desempregados da crise, consolidando o caminho para uma nova seguridade social; ii) sob a alcunha da liberdade individual, o capital retira de si qualquer responsabilidade para com o social em matéria de questão de redistribuição e a põe no próprio indivíduo. Essa passagem materializa-se baseada nas noções novas de cidadania e de justiça social, ambas atreladas à relação entre consumo e renda que produzem um duplo efeito: não só cindem imediatamente os trabalhadores em duas classes - os privilegiados e os injustiçados - como também põe na penumbra a relação essencial do capitalismo - antagonismo entre capital e trabalho.

No entanto, o projeto neoliberal padece de um problema intrínseco e recorrente que emergirá cedo ou tarde, tal como se processou no ínterim do Estado liberal do século XIX, qual seja: a difícil consertação entre exclusão/segregação e estabilização/hegemonia do próprio sistema. Assim, de plano, vem a pergunta - como conciliar neoliberalsimo e democracia? Até que ponto a assistência social será um coxim suficiente para o tratamento da questão social? Estas questões estão em aberto na medida que a disputa política entre as classes não chegou ao fim da história, tal como muitos apregoaram, após a derrocada do socialismo real ou com o fim da sociedade do trabalho.

Em uma aproximação preliminar, constata-se que a democracia não foi até aqui sinônimo da melhoria de vida material da população, trazendo consigo uma desconfiança quanto ao próprio regime. Ela - a democracia ${ }^{509}$ - torna-se sinônimo de desencanto em face do

\footnotetext{
${ }^{508}$ Fernandes, Ana Elizabete Simões da Mota. Cultura da crise e seguridade social...Op. Cit., p. 225.

${ }^{509}$ Weffort, Francisco Correia. Qual democracia?... Op. Cit.,p.105/112.
} 
não atendimento das demandas (sociais e econômicas) gestadas na ditadura e agora não implementadas.

Esta percepção quanto à insuficiência da democracia política fragiliza-a ainda mais, criando um vácuo de poder, dando ensejo da passagem da representação (parlamento e eleições) às corporações de todo tipo. Adicione-se ao antíclimax, o processo de transição acima descrito, responsável pelo não rompimento com o modelo de tomada de decisão oriundo do Estado autoritário. Somem-se, ainda, a crise econômica e a desigualdade social que são fatores locais decisivos para a obstacularização da democracia representativa, bem como de sua mutação para a democracia delegativa de tendências bonapartistas, conforme analisado no capitulo I deste trabalho.

Não é demais lembrar que a legitimidade da democracia assenta-se primeiro no anseio e depois na possibilidade real de integração político-social das camadas populares, estas aspirações, no entanto, frustram-se em um ambiente no qual "reafirma-se por um lado o valor do Estado democrático como âmbito natural da justiça e como instância estratégica de redistribuição de ingressos e de recursos e, ao mesmo tempo, ele é sacrificado e desmantelado em função do reforçamento darwiniano do mercado, procurando desse modo que o virtuoso afã de lucro dos burgueses não tropece com as interferências extraeconômicas que possam frustrar suas potencialidades de crescimento. $" 510$

Em suma, a receita neoliberal ${ }^{511}$ combinando Estado e democracia minimalistas ${ }^{512}$ reduz notadamente a capacidade deste como ator central para compensar as contradições e os problemas advindos do funcionamento do modo de produção capitalista, e isso tem duas consequências primárias: i) no plano interno - instabilidade, ingovernabilidade e, por fim, deslegitimidade do regime democrático com o retorno da situação hobessiana do salve-se quem puder, bem como na possibilidade de uma ditadura plebiscitária tantas vezes vista no decorrer da história; ii) no plano externo - dada a abertura e liberalização dos mercados mundiais, a desqualificação da mão de obra em termos de educação, saúde e proteção social, retira qualquer possibilidade de se lograr uma vantagem competitiva quando se compara com

\footnotetext{
${ }^{510}$ Borón, Atilio. A sociedade civil depois do dilúvio neoliberal. In: Sader, Emir; Gentili, Pablo (org). Pósneoliberalismo... Op.Cit., p. 71.

${ }^{511}$ Borón, Atilio. Ibid, p.100 e 108.

512 Caracterizada, segundo Borón, por dois pressupostos basilares, a saber: i) um deles é o "caráter supostamente linear e irreversível dos programas democráticos"; ii) e o outro é a crença na democracia enquanto projeto que se esgota apenas e tão somente na normalização das instituições políticas, isto é no estabelecimento de um sistema de "regras do jogo" e que se pauta por questões afetas a governabilidade e a eficácia administrativa. Nesse sentido, a democracia é reduzida a um método, dissociado dos fins, dos valores e interesses que animam as lutas dos atores coletivos a expensas das formulações clássicas. Borón, Atilio. Ibid, p. 64/65.
} 
os outros países, sobretudo os asiáticos, relegando, assim, o Brasil ao papel secundário no cenário internacional.

$\mathrm{Na}$ esteira do predomínio do ideário neoliberal, Savaris traça um relato do período, chamando-o de "política de retração sistemática do Welfare State" ${ }^{513}$ que tem por mote conjugar reformas restritivas no campo previdenciário com estratégias de redução do impacto político dessas modificações, isso tudo sob os auspícios da "nova doutrina" do Supremo Tribunal Federal. Nessa linha, o desenho original da previdência social traçado pela Constituição de 1988, seja o do RGPS (regime geral da previdência social) ou o do RPPS (regime próprio de previdência social) sofreu recortes consideráveis, não em uma direção radical de mudança de modelo (privatização com regime de capitalização), mas sim de alterações significativas e relevantes em seu arcabouço de proteção social. O norte dessas mudanças tem por perspectiva central o corte de despesa, seja a de curto como a de longo prazo e, dentre as principais medidas, podem ser destacadas: a extinção de prestações previdenciárias, a redução do conteúdo dos benefícios, como é o caso da aposentadoria por tempo de contribuição e a implementação da solidariedade do custeio, cujo exemplo mais emblemático é a obrigatoriedade das contribuições dos aposentados para o sistema (seja para o do RGPS, no instante em que ele permanece ou volta à atividade laboral; seja para o RPPS, pela via da contribuição social sobre os proventos dos inativos e dos pensionistas) sem que tal aporte tenha qualquer repercussão em seu beneficio previdenciário individualmente considerado. ${ }^{514}$

Nesse pano de pano de fundo, Savaris elenca, dentre outras, a título ilustrativo duas emendas constitucionais e duas leis ordinárias de cunho restritivo, todas elas referendadas pelo "novo posicionamento" do STF. No que tange à legislação infraconstitucional, a lei 9.032/95 representou, segundo o autor, uma verdadeira reforma na legislação previdenciária ordinária (sobretudo, na lei de benefícios do RGPS - lei 8.213/91), sendo ela responsável por: i) excluir a "pessoa designada" do rol de dependentes, ou seja, retirou-se a possibilidade do segurado poder nominar quem seriam seus dependentes para o caso dos benefícios de pensão por morte e auxílio-reclusão; ii) alteração dos critérios de cálculo de renda mensal inicial dos seguintes benefícios: aposentadoria especial, pensão por morte, aposentadoria por invalidez, auxílio-doença e dos benefícios acidentários, e com relação a estes últimos, eles foram incorporados à sistemática dos benefícios previdenciários; iii) recrudescimento das condições

${ }^{513}$ Savaris, José Antonio. O judiciário e a política de retração sistemática da previdência social brasileira. In: Folmann, Melissa; Ferraro, Suzani Andrade (coord.). Previdência nos 60 anos da Declaração dos Direitos Humanos e 20 anos da Constituição brasileira. Curitiba: Juruá, 2008, p.139/179.

${ }^{514}$ Savaris, José Antonio. Ibid, p. 150/151. 
para reconhecimento de atividade especial - efetiva e duradoura exposição aos agentes físicos, químicos e biológicos - para fins de obtenção de direito à contagem diferenciada de tempo de contribuição e aposentadoria antecipada; iv) impossibilidade de conversão do tempo de atividade comum para fins de obtenção da aposentadoria especial; v) ampliação do auxílioacidente, para além das hipóteses de acidente de trabalho; vi) vedação da acumulação de pensão deixada pelo cônjuge ou companheiro, com a ressalva do direito de opção pela mais vantajosa; vii) revogação da incorporação de $50 \%$ (cinquenta) do auxílio-acidente ao valor da pensão por morte; viii) obrigatoriedade da inscrição do segurado aposentado que exerce atividade remunerada como segurado obrigatório com contrapartida restrita ao direito ao salário-família, reabilitação profissional, ou seja, praticamente não há contrapartida para as contribuições vertidas ao sistema.

Outra lei ordinária, a lei 9.528/97, resultado da conversão de várias medidas provisórias, veio na mesma lógica restritiva de direitos semelhante aquela apontada pela lei 9.032/95, que produziu as seguintes modificações no sistema previdenciário: “i) a exclusão do menor sob a guarda do rol dos dependentes; ii) a exclusão do auxílio-acidente do rol das prestações devidas ao segurado aposentado que permanece ou retorna a exercer atividade remunerada; iii) a manutenção do auxílio-acidente, antes vitalício, até a véspera da concessão de uma aposentadoria e a integração de seu valor no salário de contribuição para o cálculo de aposentadoria; iv) a previsão de que os agentes nocivos que conduzem ao enquadramento da atividade como especial seria definido por ato do Poder Executivo e não mais por lei específica; v) a fixação do prazo de 30 dias para requerimento da pensão por morte, sob pena de se receber a referida prestação apenas a partir da data do requerimento $e$ não mais da data do óbito". 515

No âmbito constitucional, as emendas de $n^{\circ}$ 20/98 e 41/03 impingiram um novo viés ao sistema previdenciário nacional, com base nas seguintes considerações: i) a da pretensa "crise da previdência social" que atinge a todos indistintamente, sejam eles contribuintes e beneficiários de ambos os regimes (RGPS e RPPS), nos seus mais diversos momentos, quer seja aqueles que estão em gozo do beneficio ou ainda em seu período aquisitivo; ii) do imperativo das reformas restritivas de direitos com vista a viabilizar o sistema previdenciário, seja pelo incremento das receitas ou pela introdução da técnica do equilíbrio financeiro e atuarial, erigida a status de princípio constitucional.

\footnotetext{
${ }^{515}$ Savaris, José Antonio. O judiciário e a política de retração sistemática da previdência social brasileira. In: Folmann, Melissa; Ferraro, Suzani Andrade (coord.). Previdência nos 60 anos da Declaração...Op. Cit., p.158.
} 
A emenda constitucional $\mathrm{n}^{\text {o }} 20 / 98$ trouxe, em apertada síntese, as seguintes alterações: na seara do RGPS, a referida emenda estatuiu como requisito - 35 anos para homens e 30 anos para mulheres de contribuição para fazer jus à aposentadoria por tempo de contribuição; teto de beneficio pago pelo INSS a qualquer título correspondente ao valor do subsídio do Ministro do Supremo Tribunal Federal (art. 248 CF); concessão do salário-família e do auxílio-reclusão apenas para os segurados de baixa renda; integração do servidor público em cargo de comissão ou temporário ao RGPS. No âmbito do RPPS, adstrito aos servidores públicos titulares de cargo, as principais modificações passam pela instituição de idade mínima de 60 anos para homem e 55 anos para mulher quando da concessão de aposentadoria por tempo de contribuição; a previsão de regra de transição para os filiados ao tempo da data de publicação da referida emenda, consistente na exigência de idade mínima de 53 anos se homem e 48 anos se mulher mais um pedágio - contribuição adicional de $20 \%$ correspondente ao tempo de contribuição que faltava para o servidor se aposentar na data da publicação da $\mathrm{EC} \mathrm{n}^{\circ} 20 / 98$.

A Emenda Constitucional $n^{\circ} 41 / 03$, em complemento à reforma iniciada pela EC $n^{\circ}$ 20/98, avançou sobre RPPS estatuindo em linhas gerais: “i) fim da integralidade, passando o beneficio a ser calculado pela média das remunerações usadas com base para as contribuições; ii) fim da paridade; iii) redução do valor da pensão, possibilidade de instituição de um regime complementar obrigatório, por intermédio de entidades fechadas de natureza pública, para os novos servidores por lei ordinária; v) instituição de contribuição dos inativos; e vi) revogação da norma de transição do art. 8 da EC 20/98." 516 Por fim, a EC $\mathrm{n}^{\circ} 47 / 05$ a chamada "PEC Paralela" veio para arrefecer as regras da EC n041/03, para os servidores vinculados ao RPPS quando da data da publicação desta última.

Toda essa série de modificações do âmbito da proteção social pauta-se pela ótica da preservação do sistema, sob o argumento de que sua falência seria a todos deletéria, em detrimento do indivíduo, pólo fraco e necessitado atingido pela contingência social. $\mathrm{O}$ percurso da proteção agora não mais do indivíduo e sim do sistema, não passa incólume ao STF cuja postura, de acordo com Savaris, passa a ser sensível aos ditames econômicos sendo perceptível naquilo que o autor chamou de "duas doutrinas distintas", a saber: "uma primeira doutrina constituía a linha de interpretação da Suprema Corte orientada à efetivação dos princípios constitucionais de proteção social, forjada no ambiente de conquistas sociais que

\footnotetext{
${ }^{516}$ Rocha, Daniel. Curso de especialização em direito previdenciário, 2005, p. 179 apud Savaris, José Antonio. O judiciário e a política de retração sistemática da previdência social brasileira. In: Folmann, Melissa; Ferraro, Suzani Andrade (coord.). Previdência nos 60 anos da Declaração...Op. Cit., p. 165.
} 
foram consagradas na Constituição da República de 1988. Essa doutrina progressista, especialmente após a densificação dos apelos econômicos de equilíbrio financeiro cristalizados na lei 9.032/95 e na Emenda Constitucional 20/98, parece ter cedido espaço a uma outra concepção de proteção social, a qual jamais se pode dizer imune à atmosfera de austeridade que alcançou nosso País no inicio da década de noventa do século passado.

Em um tiro, a nova doutrina do Supremo Tribunal Federal é aquela que, expressa ou veladamente, se revela preocupada com o equilíbrio financeiro e atuarial - entenda-se, eficiência econômica - da seguridade social. É como se o discurso utilizado para a implementação das reformas restritivas se tornasse norma jurídica de mais alto quilate $e$ fosse acriticamente reproduzido pela maioria dos atuais magistrados do STF." 517

É importante deixar consignado que a lógica restritiva acima apontada não findou na década de 1990, ela permanece viva e é intensamente discutida nos diversos fóruns que tratam do tema. Para fins de ilustração, pode-se valer do Fórum Nacional da Previdência Social, estatuído pelo decreto 6.019/07, cujo teor dos debates segue a linha da austeridade e da retração de benefícios a sinalizar que o processo de reforma é um eterno contínuo. Savaris arrola as principais propostas feitas a partir do diagnóstico traçado pelo IPEA, instituto vinculado ao Ministério do Planejamento, a saber: “i) adoção de idade mínima para aposentadoria, com elevação gradual dessa exigência para ambos os regimes previdenciários; ii) redução gradual, até sua extinção, da diferença existente entre professores e não professores; iii) redução da diferença entre homens e mulheres referentes aos anos requeridos para aposentadoria; iv) redução do valor mínimo dos benefícios da

\footnotetext{
${ }^{517}$ A confirmar o ponto de vista do autor, podem-se ser citados os seguintes julgados: ADI 3.105 - julgamento paradigma, pois marcou a mudança do ponto de vista da corte ao decidir pela constitucionalidade da contribuição social sobre proventos e pensões dos inativos do RPPS, afastando o entendimento anterior do tribunal proferido na ADI 790-4/DF quando do julgamento da inconstitucionalidade do art. 9 da lei 8.162/91- que determinava a majoração da alíquota relativa à contribuição social dos servidores públicos federais ao tempo em que suas aposentadorias eram arcadas pelo tesouro nacional - sob o argumento da necessidade da existência da causa suficiente à majoração das contribuições sociais deveriam ter a seguinte premissa: "se nenhum beneficio pode ser criado, majorado ou estendido sem a correspondente fonte de custeio, também não poderia haver elevação das contribuições sociais para a seguridade social sem causa suficiente, isto é, sem que fosse necessária para o custeio ou extensão da seguridade social", estabelecendo, desse modo, uma correlação entre contribuições de um lado e benefícios e serviços de outro. Na linha da ADI 3.105 podem ser elencados o RE 437.640/RS constitucionalidade da contribuição social do aposentado que retorna a atividade laboral, o AI-AgR 487.075/RS - constitucionalidade da contribuição social sobre proventos e pensões dos servidores públicos e beneficiários, a ADI 2111-7/DF - constitucionalidade do fator previdenciário, introduzido pela lei 9.876/99, incidindo sobre o cálculo da aposentadoria por tempo de contribuição, RE 376.846 - constitucionalidade dos índices de reajuste dos benefícios previdenciários. Savaris, José Antonio. O judiciário e a política de retração sistemática da previdência social brasileira. In: Folmann, Melissa; Ferraro, Suzani Andrade (coord.). Previdência nos 60 anos da Declaração...Op.Cit., p.149/150 e 152/158.
} 
seguridade social." ${ }^{518}$ Ressalte-se que todas essas propostas dirigem-se ao enquadramento dos "problemas residuais" não atacados pelas reformas pretéritas (ausência de idade mínima no RGPS, aposentadoria precoce dos professores e mulheres, vinculação do salário mínimo à previdência social) e têm elas por pano de fundo aquilo que Offe chama de instância suprapartidária cujo fim último visa a "proteger o Estado de reivindicações excessivas de grupos sociais, desacreditando-as".

Para além da ideia do neoliberalismo - do problema da crise ser de todos e necessitar do sacrifício de todos que no fundo propugna por velar o ideal de expansão do privado/mercado nos domínios do social -, Savaris, apoiado em Paul Pierson, lista algumas das técnicas voltadas a mitigar justamente o custo político das alterações acima arroladas, na medida que "os defensores das políticas restritivas enfrentarão uma colisão entre suas preferências políticas e suas ambições eleitorais, razão pela qual eles necessitam de estratégias para receber apoio popular nos planos de austeridade ou para minimizar seus custos políticos." 519 Dentre as estratégias para reduzir o custo político pela implementação das políticas restritivas de bem-estar social, pode-se mencionar, segundo Savaris: i) o ofuscamento de informações; ii) divisão de seus opositores potenciais; iii) compensação para os afetados pelas mudanças propostas.

A estratégia do ofuscamento é a principal e mais relevante e pode ser decomposta em três matizes. A primeira delas é a da redução da visibilidade dos efeitos negativos da reforma e o processo brasileiro parece, de acordo com Savaris, afeiçoa-se muito com essa dimensão, "porque os cortes nos benefícios são realizados aos poucos, ao longo do tempo, mas de forma persistente. Também não foge dessa tendência a dança de indicies de reajustamento dos benefícios previdenciários do RGPS, desde a edição da lei 8.213/91, sendo responsável por milhares de ações judiciais que contestaram o método de recomposição do poder de compra dos benefícios. A sensação de perda por diminuição é manifesta." 520

A segunda matiz versa sobre as reformas de efeitos indiretos e do aumento da complexidade das reformas, indo ao encontro da estratégia do ofuscamento. Um bom exemplo desse modus operandi é a introdução do fator previdenciário - uma fórmula atuarial de difícil compreensão - que incide sobre as aposentadorias por tempo de contribuição e por idade, sendo ao final prejudicial ao titular do benefício. E, ainda, dentro do ofuscamento,

\footnotetext{
${ }^{518}$ Savaris, José Antonio. O judiciário e a política de retração sistemática da previdência social brasileira. (IN) Folmann, Melissa; Ferraro, Suzani Andrade (coord.). Previdência nos 60 anos da Declaração...Op. Cit., p. $166 / 167$

${ }^{519}$ Savaris, José Antonio. Ibid, p.167.

${ }^{520}$ Savaris, José Antonio. Ibid, p. 169.
} 
pode-se extrair um terceiro viés, que é o blame avoidance, que se baseia no apartamento do governo da política de restrição dos direitos e se concretiza pelo retardamento da implementação da reforma, cujo exemplo mais gritante é o das regras de transição, "segundo as quais os efeitos da nova legislação se aplicam apenas para futuros beneficiários e tanto de forma menos intensa quanto estiverem próximos do cumprimento dos requisitos legais para recebimento do beneficio." 521

A segunda estratégia elencada por Savaris é a da divisão dos opositores em potencial, fazendo as reformas em blocos e isolando os potenciais grupos de pressão, o modus operandi mais fácil de executar tal medida é pelo endurecimento dos requisitos de acesso aos benefícios. Nessa linha, excetuando a EC n $20 / 98$ que tratou tanto do RGPS como do RPPS, as reformas da legislação previdenciária no Brasil tendem ora a restringir direitos dos segurados do RGPS, ora dos segurados do RPPS. Por fim, uma terceira estratégia é a do grandfather clauses que nada mais é do que uma modalidade de compensação às vitimas das políticas restritivas a fim de angariar apoio popular e contornar eventuais resistências de grupos organizados. Feita essa breve incursão dentre algumas das modalidades de arrefecimento dos prejuízos políticos imediatos que poderiam advir das reformas neoliberais, o que é relevante deixar consignado é que cada uma dessas táticas acima se fazem presentes seja de forma isolada ou não no contexto das alterações legislativas no curso da década de 1990 e do inicio dos anos 2000.

\section{5) Quarta aproximação - direitos sociais do conceito à frágil consolidação.}

O Estado social funda-se na implementação e consolidação de direitos sociais como meio de acesso aos direitos declarados universais em documentos nacionais ou internacionais chancelados por gastos estatais, dados a partir de critérios legais (contribuições ou necessidades). O que no fundo se tenta, por meio do fundo público, é buscar uma relativa harmonia entre "cidadania e desmercadorização ou desmercantilização da força de trabalho, a garantia de direitos ao trabalhador no sistema capitalista de produção" ${ }^{„ 522}$, em um contínuo processo de lutas e conflitos de classe que redundam na modificação das condições do capitalismo liberal. Ou seja, "o direito social e o conseqüente Estado social são produtos do

\footnotetext{
${ }^{521}$ Savaris, José Antonio. O judiciário e a política de retração sistemática da previdência social brasileira. In: Folmann, Melissa; Ferraro, Suzani Andrade (coord.). Previdência nos 60 anos da Declaração...Op. Cit., p. 170.

${ }^{522}$ Faleiros, Vicente de Paula. A política social do Estado capitalista...Op. Cit., p.66.
} 
modelo capitalista de produção. Significam, entretanto, um modo do capitalismo tentar demonstrar-se viável como elemento regulador dos padrões de conduta da humanidade ". 523

Os direitos sociais ${ }^{524}$ são, na verdade, a própria realidade social que combina passado (necessidade por proteção efetiva) e futuro (germe de necessidades novas), cujo sinergismo se traduz em exigências vinculadas a disputas entre capital e trabalho com vista a ampliar ou não a rede e a densidade das políticas sociais em um ambiente de democracia como solução da questão social. Como participação mínima na riqueza social (material e espiritual), os direitos sociais ${ }^{525}$ são símbolos do Estado de Bem-Estar e representam uma conquista ainda maior do que a dos direitos políticos logrados no século XIX, de modo que não se pode tomá-los, como simples instrumentos de manutenção da ordem pela obtenção do consenso ou de ampliação da taxa de acumulação de lucro.

Esse viés de conquistas não obsta que em determinadas conjunturas históricas, as políticas sociais voltem-se contra a própria classe trabalhadora, mais especificamente para sua desmobilização e cooptação, pois "assim como no caso do sufrágio universal (que não garante automaticamente a vitória dos trabalhadores), também nesse terreno das políticas sociais nada está decidido a priori: embora tanto os direitos políticos como os direitos sociais sejam importantes conquistas dos trabalhadores, pode ocorrer que - em determinadas conjunturas e em função de correlações de forças especificas - eles não explicitem plenamente seu potencial emancipatório. Para que tal ocorra, é mais uma vez necessária à intensificação das lutas pela realização da cidadania, com o estabelecimento de correlações de força favoráveis aos segmentos sociais efetivamente empenhados nessa realização". 526

Os dizeres acima de Carlos Nelson Coutinho, com a ressalva quanto ao potencial emancipatório dos direitos sociais discutida anteriormente, dão bem a mostra do quadro atual que se perpassa com o modelo neoliberal opondo frontalmente a esse tipo de Estado e, mais especificamente, aos direitos sociais, de modo a demonstrar a incongruência entre "liberalismo e democracia", o que traz à tona o embate entre as "exigências antidemocráticas da ordem do capital e as requisições democráticas radicais do trabalho" - o verdadeiro antagonismo da sociedade. Essa disputa é a evidência real de que a burguesia não tem o menor apreço aos direitos sociais ${ }^{527}$.

\footnotetext{
${ }^{523}$ Maior, Jorge Luiz Souto; Correia, Marcus Orione Gonçalves. O que é direito social? In: Correia, Marcus Orione Gonçalves. Curso de direito do trabalho...Op. Cit., p.23.

${ }_{525}^{524}$ Santos, Cleusa. A seguridade social e a esfera dos serviços. Universidade e Sociedade...Op. Cit., p.63.

${ }^{525}$ Coutinho, Carlos Nelson. Contra a corrente...Op.Cit., p. 63/66.

${ }^{526}$ Coutinho, Carlos Nelson. Ibid, p.66.

${ }^{527}$ Coutinho, Carlos Nelson. Ibid, p.67/68.
} 
Em face de determinadas conjunturas, os direitos sociais hão de ser tolerados e, até mesmo, usados em favor da classe dominante, mas o objetivo último é a busca incessante por sua redução a um mínimo. Esse movimento exacerba-se nos períodos de crise do sistema capitalista, haja vista que a lógica do capital não se coaduna a dos direitos sociais, que de uma forma ou de outra, avança sobre a taxa da mais valia. E é essa hoje a contradição premente na sociedade que se desenvolve sob o roteiro de resistências, recuos e concessões, onde o capital busca reiteradamente incorporar os direitos conquistados à sua lógica.

Nesse sentido, os direitos sociais, bem como as políticas sociais que o informam hão de ser compreendidas sempre no interior do contexto estrutural e conjuntural das transformações sociais do capitalismo e, mais precisamente, no interior da relação entre Estado e o processo de acumulação de capital.

As políticas sociais do Estado $^{528}$ são a resultante concreta da luta de classes que, simultaneamente, sancionam as situações de classe. Isso porque as lutas traduzem-se em direitos em um pacto que incorpora, contraditoriamente, os interesses do capital e do trabalho com o predomínio para aquele - que se traduz pelo exercício da hegemonia. Contradição essa que se dissolve em torno da chamada preocupação com os direitos humanos ${ }^{529}$, cujo discurso gravita sob a égide de uma pretensa igualdade social, mas que no fundo está a serviço da reprodução do sistema - mais especificamente na gestão estatal da força de trabalho.

O traço de dubiedade das políticas sociais reside na dupla valorização - a do capital e a da força de trabalho nas modalidades "mercadoria especial (produtora da mais valia) e sujeito de direito no interior da cidadania democrática" ${ }^{, 530}$. As próprias políticas, em face do viés fragmentário/setorizado, trabalham com discrimens, tornam plausível a convivência

\footnotetext{
${ }^{528}$ Faleiros, Vicente de Paula. A política social do Estado capitalista...Op. Cit., p. 63/64.

${ }^{529}$ No tocante aos direitos humanos cabem duas considerações: A primeira versa sobre a sua estrutura assentada sob a matriz do sujeito-indivíduo. Tanto a Declaração dos Direitos do Homem e do Cidadão como a Declaração Universal dos Direitos Humanos de 1948 têm sua lógica desenvolvida na centralidade do individuo, seja como ontologia do direito, seja como limite ao absolutismo do individuo através do reconhecimento do outro. Santos, Laymert Garcia. Tecnologia, perda do humano e crise do sujeito de direito. In: Oliveira, Francisco de; Paoli, Maria Célia. Os sentidos da democracia....Op. Cit.,p.302.

A segunda há de se dividir em dois momentos: i) o da primeira declaração (1789) basta retomar as críticas de Marx na Questão Judaica, ao analisar a separação entre o cidadão e o burguês, trazidas no capitulo I deste trabalho; ii) Quanto à segunda declaração (1948) não restam dúvidas de que houve avanços na medida em foram incorporados os direitos econômicos, sociais e culturais. No entanto, os problemas iniciam-se já na analise da sua natureza - força jurídica ou recomendação, discussão esta que se materializou na cisão entre os pactos internacionais - direitos civis e políticos/econômicos e sociais.

Se pelo viés da positivação, verifica-se, de plano, uma insuficiência do pacto dos direitos econômico e social quando comparado ao pacto dos direitos civis e políticos no que tange ao numero de ratificações; o problema maior reside na efetivação daquele pacto, na medida em que a realidade dos direitos humanos volta-se, precipuamente, a violação dos direitos civis e políticos, que, no limite, equipara-os, deixando os direitos sociais para o mercado. Piovesan, Flávia. Os direitos humanos e o direito constitucional internacional...Op. Cit., p. 136/148, 160/168, 174/184, 330.

${ }^{530}$ Faleiros, Vicente de Paula. A política social do Estado capitalista...Op. Cit., p. 70.
} 
"harmoniosa" entre valorização e de desvalorização da força de trabalho no mesmo espaço e tempo, na medida que elas se relacionam com o excedente populacional - população socialmente excluída. Sem contar que o quadro ganha em complexidade se se pensar que a classe trabalhadora não é um todo homogêneo, na verdade, ela acompanha as diversas variações dos setores produtivos, dentre os quais podem se reconhecer dois grandes grupos: o do setor monopolista e o do concorrencial, nos quais os impactos dessas políticas são distintos, vide o exemplo histórico do período militar-fordista no item pretérito.

Na ponta da valorização do capital ${ }^{531}$, a política social corrobora com "a insegurança do emprego e a disciplina do trabalho", pois não rompe a relação "renda e esforço produtivo", na medida que o fundamento último das políticas sociais é a empregabilidade da força de trabalho. O modus operandi dessa valorização que não tem por escopo retirar as agruras dos trabalhadores, processa-se, basicamente, de quatro maneiras: i) o salário indireto oriundo das políticas sociais tem por escopo o retorno ao trabalho; ii) o traço de perenidade de qualquer política social na medida que se é impossibilitado de se viver dela; iii) o enfoque dado pela administração ao combate às fraudes; iv) as próprias pressões advindas da sociedade para o retorno ao trabalho.

Já na ponta oposta - o da valorização e reprodução da força de trabalho ${ }^{532}$ - políticas sociais objetivam: no que tange ao elemento valorização, na esteira da "formação do capital humano", manter uma força apta ao trabalho pelos mecanismos mais diversos dentre eles citam-se capacitação, educação, saúde, etc... Quanto a sua reprodução, elas voltam-se precipuamente à restauração da capacidade de trabalho, à manutenção da disponibilidade e da empregabilidade, bem como à reprodução de novos trabalhadores. O mais significativo de tudo isso é que essa dupla validação tem como resultado a ratificação do status quo pela manutenção/reprodução do contexto social, na medida que serviços e prestações oriundos das políticas públicas não só são adstritos à própria situação de classe, como também impõem a sua chancela na base da discriminação. Ou seja, ela tem uma dupla face: a imediata que é a estigmatização e mediata que é a ocultação da realidade social produzida em um regime capitalista.

Outro aspecto relevante no tocante às políticas sociais diz respeito ao excedente populacional $^{533}$ - o assim denominado exército industrial de reserva, fruto do desenvolvimento das forças produtivas - as políticas públicas e, em particular, a assistência

\footnotetext{
${ }^{531}$ Faleiros, Vicente de Paula. A política social do Estado capitalista...Op. Cit., p.70/71.

${ }^{532}$ Faleiros, Vicente de Paula. Ibid, p.72 e 76.

${ }^{533}$ Faleiros, Vicente de Paula. Ibid, p.74/75.
} 
social tem por mister conservá-lo em condições de "substituição qualificada" imediata da força de trabalho, excedente esse mantido com "benefícios inferiores aos daquele praticados no mercado". O regime da assistência possui duas vertentes: uma econômica, manter "aquecida" as economias locais, ou seja, buscando no fundo privilegiar o fator produção, dado que o fator consumo não se resolve pelo beneficio. Derivando o aspecto econômico da assistência para a Seguridade, como um todo (e aqui está a se falar de aposentadorias e pensões, cuja diferença essencial é o volume de recursos ai disponibilizados e nem tanto o valor do benefício quando se compara com a assistência social).

O relatório da Anfip de 2007 dá uma boa dimensão do quão fundamental é o papel da Seguridade para as economias dos municípios brasileiros, haja vista que em mais de $60 \%$ (sessenta por cento) deles, os recursos previdenciários suplantam o montante recebido do fundo de participação dos municípios (FPM). ${ }^{534}$ A segunda vertente trabalha na base do discurso da valorização do homem dentre de limites restritos, na medida que "mesmo estigmatizado pela recepção da ajuda, o indivíduo se sinta validado socialmente por uma política que não o valoriza."

Cabe mencionar ainda na esteira da política neoliberal introduzida no país, pós-anos de $1990^{535}$, que o setor informal da economia passa a ser visto não mais como atraso ou manifestação da pobreza mas sim como forma de combatê-la, conforme a informalidade é relida agora como "fonte de riqueza com potencial inexplorado" justificando, dessa forma, o avanço tanto à assistência social como a "versão assistencializada da previdência social" no universo das políticas sociais do Estado.

Do exposto, é importante se ater que os direitos sociais ${ }^{536}$ têm por ontologia a busca de compensações pelo viés da introdução da justiça distributiva, da equidade ou da igualdade de oportunidades. Todavia, esse ideário é adstrito a determinados padrões inerentes a um Estado capitalista de modo que se tem a garantia de um mínimo (deixando o restante para o mercado), instrumentalizado na base do individualismo (sujeito de direito), da universalidade (igualdade perante a lei), da livre escolha do indivíduo, da institucionalização dos conflitos e da cobertura de riscos sociais, riscos estes advindos de uma economia de mercado.

Estas características são sancionadas pelo sistema jurídico e, em especial, pela Constituição de 1988 de onde se observa a correlação imediata dos direitos sociais, ${ }^{537}$ com a

\footnotetext{
${ }_{534}^{534}$ Anfip. Análise da seguridade social em 2006...Op. Cit.

${ }^{535}$ Fernandes, Ana Elizabete Simões da Mota. Cultura da crise e seguridade social...Op.Cit.,p.144/145.

${ }^{536}$ Faleiros, Vicente de Paula. A Política Social do Estado Capitalista...Op. Cit., p. 49/51.

${ }^{537}$ Maior, Jorge Luiz Souto; Correia, Marcus Orione Gonçalves. O que é direito social? In: Correia, Marcus Orione Gonçalves. Curso de direito do trabalho...Op. Cit., p.23, 24, 26, 31, 32.
} 
disputa capital e trabalho - vide os direitos trabalhistas e previdenciários - e mediatamente com o direito a direito à vida (art. 6 da $\mathrm{CF}$ ), cujos pilares são dados pelos princípios da dignidade da pessoa humana e da prevalência dos direitos humanos (art. 1 e 4 da CF). Desse modo, pode-se conceituar o direito social como "regra de caráter transcendental, que impõem valores à sociedade (...) Os valores são: a solidariedade (como responsabilidade social de caráter obrigacional), a justiça social (como conseqüência da necessária política de distribuição dos recursos econômicos e culturais produzidos pelo sistema), e a proteção da dignidade humana (como forma de impedir que os interesses econômicos suplantem a necessária respeitabilidade a condição humana). (...) A imposição desses valores se dá tanto ao Estado, como propulsor das políticas de promoção social e de garantidor das normas jurídicas sociais, quanto a todos os cidadãos, nas suas correlações intersubjetivas. Nesse ponto, destaque-se a importância dos movimentos sociais para a sua consolidação",. 538

Da definição, diga-se, de passagem, bem ampla para além da relação capital e trabalho, depreende-se que os direitos sociais pelo viés valorativo da própria condição humana representam o ponto de inflexão da ordem jurídica liberal na medida que propugnam por "algum retorno de natureza social". Todavia, esses mesmos direitos enquanto elementos informadores das políticas sociais não romperam com "o ideário liberal", isso porque o enfrentamento pelo Estado das consequências da questão social se faz pelo "substrato individualista", na forma do sujeito individual responsável pelo seu destino, conforme cabe a ele aproveitar ou não as possibilidades que são postas a seu alcance. É desse modo que se perfaz a ação do Estado sobre a questão social pelo corte e pela recuperação do ideário liberal - "corta-o, intervindo através de políticas sociais; recupera-o, debitando a continuidade de suas seqüelas aos indivíduos por elas afetados", 539 consolidado assim "o ethos individualista", onde o destino é individual, o que, no limite, reitera a legitimação do status quo.

Pelo viés da dominação material, são redefinidos os conceitos de público e do privado na medida que há uma incursão definitiva da lógica do capital em todas as esferas sociais, pois a lógica do capital monopolista tende a espraiar-se para todos os domínios da vida - pela “conversão do capital ocioso em capital de serviços e ao mesmo tempo substituir

\footnotetext{
${ }^{538}$ Maior, Jorge Luiz Souto; Correia, Marcus Orione Gonçalves. O que é direito social? In: Correia, Marcus Orione Gonçalves. Curso de direito do trabalho...Op. Cit., p.26.

${ }^{539}$ Netto, José Paulo. Capitalismo monopolista e serviço social...Op.Cit., p. 36.
} 
serviços por capital produtivo - ou seja, substituir serviços por mercadorias, atingindo a esfera da seguridade social." 540

A intervenção do Estado sobre a questão social, mais especificamente sobre sua refração, observa e garante essa lógica, mas não em uma aderência linear do tipo economicista; na verdade, ela se realiza perpassando os instantes do público e do privado. Linhas gerais, o público se faz visível nas conjunturas críticas do sistema e o privado nas demais. O importante é perceber que não há uma exclusão definitiva de uma ou de outra, o que existe é uma "complementaridade indescartável entre ambos" "541. A tensão existente entre privatização e estatização da questão social é ínsita à própria contradição da sociedade capitalista e em um contexto de globalização, toma força o processo de privatização das áreas sociais realizado em uma simbiose entre o público e o privado, em uma espécie de "transformação programada dos serviços públicos em mercadorias" - setores da saúde, educação, etc.... ${ }^{542}$ Mas mesmo dentro dessa ambiência favorável ao privado, a doutrina liberal não refuta o tratamento público dado à questão social, o que ela o faz é tentar reduzir os esquemas de atuação deste a um mínimo - direitos sociais seletivos e particularistas - que objetivam apenas e tão somente equacionar as refrações da questão social, mais especificamente, a pobreza sem jamais atacar suas causas. Nessa lógica de privatização e focalização da proteção social, o neoliberalismo não apenas não consegue como não quer se desvencilhar de alguns dos padrões institucionais de ação do Estado de Bem-Estar social.

Pelo viés da dominação espiritual ${ }^{543}$, "o estilo de pensar o social” - positivismo remete à naturalização da sociedade, na qual o sujeito é impotente frente ao desenvolvimento natural das coisas o que possibilita e fundamenta o discurso da reforma social pela via do progresso do existente e não de sua destruição. Ademais, o central é que a neutralidade do social ancora-se nas dimensões da ética e da moral - performação da escatologia kantiana que no limite deixa campo livre "a psicologização das relações sociais". Para além de descer às minúcias do percurso da psicologização social, o relevante é saber que ela além de referendar o ethos individualista, presta-se como alavanca de legitimação da ordem social vigente, na medida que "constitui em verdadeira pedagogia psicossocial, voltada para sincronizar as

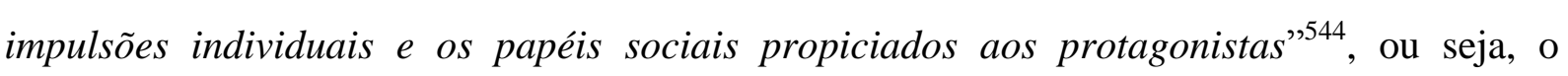

\footnotetext{
${ }^{540}$ Santos, Cleusa. A seguridade social e a esfera dos serviços. Universidade e Sociedade...Op. Cit., p.64.

${ }^{541}$ Netto, José Paulo. Capitalismo monopolista e serviço social...Op.Cit., p.40.

${ }^{542}$ Santos, Cleusa. A seguridade social e a esfera dos serviços. Universidade e Sociedade...Op. Cit., p.64.

${ }^{543}$ Netto, José Paulo. Capitalismo monopolista e serviço social...Op.Cit., p. 43/45.

${ }^{544}$ Netto, José Paulo. Ibid, p.42.
} 
elemento ordem é a veia predominante a pautar a sociedade burguesa, bem como a própria intervenção do Estado.

De todo o exposto, objetivou traçar as perspectivas e os limites dos direitos sociais, das políticas sociais do Estado, enfim da seguridade social dentro de uma ordem capitalista para além de um matiz de concessão de direitos pela burguesia ou de conquista dos trabalhadores ou mesmo de uma leitura linear, limitando-a ao desenvolvimento do capitalismo. A questão que permeia e que informa toda a historicidade da seguridade social "reside no fato de o capital ser compelido a incorporar algumas exigências dos trabalhadores, mesmo que elas sejam conflitantes com os seus interesses imediatos; mas, ao fazê-lo, procura integrar tais exigências à sua ordem, transformando o atendimento delas em respostas políticas que, contraditoriamente, também atendem às suas necessidades. A dinâmica desse processo adquire características particulares, dependendo do estágio de desenvolvimento das forças produtivas, do grau de socialização da política e das formas históricas assumidas pelo confronto entre as classes." 545

\footnotetext{
${ }^{545}$ Fernandes, Ana Elizabete Simões da Mota. Cultura da crise e seguridade social...Op. Cit.,p.123.
} 


\section{Conclusão}

Em seus três matizes (filosófico - individualismo, político - Estado de direito e o econômico propriamente dito) o liberalismo mostrou ao longo de seu percurso histórico uma dificuldade intransponível em suplantar qualquer esquema de democracia que não seja a formal, ou seja, aquela democracia adstrita à gênese lógico-histórico da separação entre Estado e sociedade, objetivando, primeiro, sua "eterna manutenção", e depois seu "eterno retorno" a um rol restrito de direitos, oriundos do jusnaturalismo, gravitando todos eles ao redor dos direitos de propriedade.

Ao longo do século XIX, as lutas de classe tiveram como mérito primeiro o alargamento do reconhecimento dos direitos civis e políticos para o conjunto da sociedade. Depois esta democracia estabelecida tornou vulnerável o Estado, como instância canalizadora e amortizadora dessas disputas políticas, às demandas sociais e possibilitou a legitimação e a garantia do modelo capitalista, sendo a Constituição o produto mais bem acabado desse consenso estabelecido. Isso porque a discussão a respeito da incorporação dessas demandas sociais no Estado há de considerar os interesses contraditórios existente entre capital e trabalho ao fazer com que na base da linguagem jurídica (que é uma linguagem eminentemente burguesa) sejam elas incorporadas de forma seletiva, voltando-se, reiteradamente às consequências e não às causas da questão social. Nessa linha, o comparativo feito entre os programas assistenciais de combate à pobreza, quer sejam os dos Estados liberal ou Social, com o modelo do programa renda básica desenvolvido por Van Parijs, é uma boa mostra dos limites, possibilidades, bem como da ótica adotada por cada um deles.

Mesmo como inflexão do projeto burguês de dominação, os direitos sociais e as políticas sociais do Estado traduzem-se e expressam-se pelo substrato individualista, na forma de sujeito individual responsável, pelo seu próprio destino, na medida que cabe a ele valer-se ou não das possibilidades que estão a seu alcance. Isso, no limite, está a referendar não apenas o ethos individualista, como também a reiterar o status quo. A própria intervenção do Estado sobre os efeitos da questão social é feita, perpassando os instantes públicos e privados a depender da conjuntura do sistema, e o público se faz presente nos momentos mais críticos e o privado, nos demais, transparecendo, dessa forma, a complementaridade entre ambos. Isso é perceptível mesmo na doutrina liberal - propugna pela privatização e pela focalização dos esquemas de proteção social - que não refuta o tratamento público dado à questão social, o 
que ela objetiva é reduzir ao mínimo os esquemas de atuação na base de direitos sociais seletivos e particularistas com o intuito de aplacar as consequências da pobreza.

A leitura acima permite colher os direitos sociais sob dois vieses: i) limite máximo do sistema, muito aquém de qualquer tentativa de saída do modelo capitalista, ii) limite de resistência, de relativo equilíbrio entre capital e trabalho na base do desenvolvimento das forças produtivas com o desenvolvimento ou não da política, o que denota uma dupla impossibilidade: seja a da superação da ordem capitalista, seja a do desmonte total do Welfare State.

Em face das necessidades da estrutura de produção fordista, até mesmo em um ambiente de ausência de democracia, como por exemplo, foi o caso do Brasil nos anos de 1960 a 1980, os direitos sociais foram em alguma medida fomentados e desenvolvidos. Agora, esses mesmos direitos são abandonados no modelo toyotista de produção, de tal modo que sua manutenção desprende-se dos imperativos econômicos e encontra guarida apenas na seara política, residindo aí a importância de fatores como mobilização de classe e as estruturas de coalizão política das classes, de modo a impingir maior ou menor resistência aos avanços neoliberais.

Há, ainda, a questão do fundo público estatal que outrora alimentava os direitos sociais passa agora a ser disputado para fins outros. Visto que, se no Welfare State, afastada a ideia de que esse Estado fosse uma modalidade de Hobin Hood, os gastos sociais em sua maioria são financiados pela classe trabalhadora. No Estado neoliberal, esses gastos sociais são direcionados aos credores da dívida pública, fazendo com que afinal a exploração da classe trabalhadora transcenda àquela ocorrida na esfera da produção e mesmo à oriunda dos mecanismos tradicionais do Welfare State.

No caso brasileiro em face de sua peculiaridade histórica - capitalismo tardio e periférico -, essa disputa é ainda mais acentuada no sentido da não implementação e da não consolidação dos direitos sociais previstos na Constituição quando esta se depara com os legados da ditadura - crise econômica e desigualdade social - e com a nova ordem econômica internacional. Esses fatores em seu conjunto somados à incipiente política do país vão redundar em um novo perfil da seguridade social no Brasil, a qual conjuga privatização e assistencialização.

O caminho tomado pela seguridade social remonta à pergunta deixada em aberto quando da análise da crise econômica de 2008 (se os esquemas de proteção social adotados pela política neoliberal terão resultado satisfatório para arrefecer as conseqüências sociais da crise econômica)? Pergunta esta que tem uma derivação última, posta na seguinte indagação: 
até quando o receituário neoliberal mostrar-se-á um eficiente mecanismo para legitimar a democracia minimalista que se instaurou nos idos dos anos de 1990? Uma resposta preliminar para o caso brasileiro é a manutenção e a consolidação do país como ator secundário no cenário mundial.

Para os domínios dos direitos sociais, da mesma forma que o Welfare State fora reduzido em algumas décadas, o Estado Neoliberal, a depender da conjugação de forças na sociedade, pode vir a ser ampliado. Esse eventual movimento pendular do Estado há de ser pensado sem perder de vista os limites do possível dados pelos direitos sociais, cuja extensão máxima é possível apenas como elemento informador de uma "cidadania social" que não é sinônimo de revolução nem de socialismo. 


\section{Bibliografia}

ANDERSON, Perry. Balanço do neoliberalismo. In: SADER, Emir; GENTILI, Pablo (org).

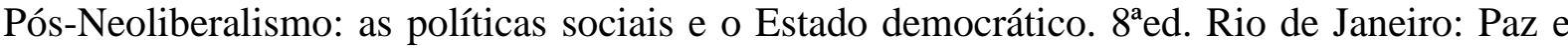
Terra, 1995, p. 9-23.

ALMEIDA, Silvio Luiz de. O direito no jovem Lukács: a filosofia do direito em História e Consciência de Classe. São Paulo: Alfa-Omega, 2006.

ALTHUSSER, Louis. Política e história, de Maquiavel a Marx: curso ministrado na École Normale Supériure de 1955 a 1972. Texto estabelecido, anotado e apresentado por François Matheron. Tradução de Ivone C. Benedetti. São Paulo: Martins Fontes, 2007.

ALVES, Giovanni. Trabalho e sindicalismo no Brasil dos anos 2000. Dilemas da era liberal. IN: ANTUNES, Ricardo (org). Riqueza e miséria do trabalho no Brasil. São Paulo: Boitempo, 2006, p.463-474.

Trabalho e mundialização do capital. A nova degradação do trabalho na era da globalização. $2^{\text {a } e d . ~ L o n d r i n a: ~ P r a x i s, ~ 1999, ~ p .54-77 . ~}$

ANFIP. Análise da seguridade social em 2006. Brasília: ANFIP, 2007. Disponível em: http://www.anfip.org.br/publicações/livros/arqs-swfs/analise_2006swf. Acessado em $12 / 08 / 09$.

ANFIP. Análise da seguridade social em 2008. Brasília: ANFIP, 2009. Disponível em: http://www.anfip.org.br/publicacoes/livros/arqs-pdfs/analise_2008.pdf. Acessado em: $12 / 08 / 09$

ANTUNES, Ricardo. Adeus ao Trabalho? Ensaios sobre as metamorfoses e a centralidade do mundo do trabalho. $2^{\mathrm{a}}$ ed. Campinas: Cortez, 1995, p.41-55.

ARISTÓTELES. A política. $3^{\mathrm{a}}$ ed. Tradução de Roberto Leal Ferreira. São Paulo: Martins Fontes, 2006. 
BAUMAN, Zygmunt. Em busca da política. Tradução de Marcus Penchel. Rio de Janeiro: Jorge Zahar, 2000.

BELlUZZO, Luiz Gonzaga de Mello; COUTINHO, Luciano. O desenvolvimento do capitalismo avançado e a reorganização da economia mundial no pós-guerra. In:

Estudos Cebrap, $\mathrm{n}^{\circ}$ 23, São Paulo, 1981. Disponível em: http://www.cebrap.org.br/imagens/Arquivos/o_desenvolvimento_do_capitalismo_avancado.p df. Acessado em 05/07/07.

BERCOVICI, Gilberto. A problemática da Constituição dirigente: algumas considerações sobre o caso brasileiro. Revista de Informação Legislativa, Brasília, ano 36, n 142, p. 35-51, abr/jun 1999.

Constituição e estado de exceção permanente. Atualidade de Weimar. Rio de Janeiro: Azougue Editorial, 2004.

. Soberania e Constituição: para uma crítica do constitucionalismo.

São Paulo: Quartier Latin, 2008.

BERCOVICI, Gilberto; MASSONETTO, Luís Fernando. A constituição dirigente invertida: a blindagem da constituição financeira e a agonia da constituição econômica. Coimbra: Boletim de Ciências Econômicas XLIX, p. 3-23, 2006.

BITTAR, Eduardo Carlos Bianca. O direito na pós-modernidade. Rio de Janeiro: Forense Universitária, 2005.

BRAGA, Rui. Uma sociologia da condição proletária contemporânea. Tempo Social, São Paulo, v.18, n.1, junho 2006. Disponível em: http://www.scielo.br/scielo.php?script=sci_arttext\&pid=S010320702006000100008\&lng=pt \&nrm=iso. Acessado em 04/07/07.

BOBBIO, Norberto. Estado, governo, sociedade. Para uma teoria geral da política. $13^{\mathrm{a} e d .}$ Tradução de Marco Aurélio Nogueira. Rio de Janeiro: Paz e Terra, 2007. 
Nem com Marx, nem contra Marx. Tradução de Marco Aurélio Nogueira. São Paulo, Unesp, 2004.

Teoria geral da política. A filosofia política e a lição dos clássicos. Tradução de Daniela B. Versiani. Rio de Janeiro: Campus, 2000.

BONAVIDES, Paulo. Curso de direito constitucional. 22ª ed. São Paulo: Malheiros, 2008.

Do Estado liberal ao Estado social. São Paulo: Saraiva, 1961.

Teoria do Estado. São Paulo: Saraiva, 1967, p. 1-126 e 161-199.

BORÓN, Atilio. A sociedade civil depois do dilúvio neoliberal. In: SADER, Emir; GENTILI, Pablo (org). Pós-neoliberalismo: as políticas sociais e o Estado democrático. Rio de Janeiro: Paz e Terra, 1995, p.63-118.

.O Pós-Neoliberalismo é uma etapa em construção. In: SADER, Emir; GENTILI, Pablo (org). Pós-neoliberalismo: as políticas sociais e o Estado democrático. Rio de Janeiro: Paz e Terra, 1995, p.185-196.

BOURDIEU, Pierre. Meditações pascalianas. Tradução de Sergio Miceli. Rio de Janeiro: Bertrand Brasil, 2001.

BUCCI, Maria Paula Dallari. O conceito de política pública em direito. In: - Políticas públicas. Reflexões sobre o conceito jurídico. São Paulo: Saraiva, 2006, p.1-51.

CALCIOLARI, Ricardo Pires. Progressividade tributária, segurança e justiça fiscal. Revista Tributária e de Finanças Públicas, São Paulo, ano 15, nº 76, p. 198-225, set/out 07.

A crise de efetividade dos direitos sociais e a desvinculação de receitas. In: Da ROCHA, Daniel Machado; SAVARIS, José Antonio (coord). Curso de Especialização em Direito Previdenciário. Vol. 3, Custeio da Seguridade Social. Curitiba: Juruá Editora, 2008, p.35/71. 
CALDAS, Camilo Onoda. Perspectivas para o direito e a cidadania. O pensamento jurídico de Cerroni e o marxismo. São Paulo: Alfa-Omega, 2006.

CAPPELlETTI, Mauro; GARTH, Bryant. Acesso à justiça. Tradução Ellen Gracie Northfleet. Porto Alegre: Sergio Antonio Fabris Editor, 2002, p. 7-29.

CAPPELLETTI, Mauro. Juízes legisladores? Tradução de Carlos Alberto A. de Oliveira. Porto Alegre: Sergio Antonio Fabris Editor, 1993.

CHESNAIS, François. A mundialização do capital. Tradução de Silvana F. Foá. São Paulo: Xamã editora, 1996, p. 13-44 e 237-271.

.Até onde irá à crise financeira. Disponível em: http://duplo.uol.com.br/2007-11a1993. Acessado em 29/08/09.

- Introdução geral. In:

A mundialização financeira.

Gênese, custos e riscos. Tradução de Carmem C. Cacciacarro, Luis Leiria, Silvana Foá e Valéria C. da Paz. São Paulo: Xamã editora, 1998, p. 7-33.

CHIARA, José Tadeu de. A moeda e a ordem jurídica. 1986. 217 f. Tese (Doutorado em Direito Econômico) - Faculdade de Direito, Universidade de São Paulo, São Paulo, 1986.

COELHO, Roseli Martins. Social-democracia: formas e reformas. São Paulo: Humanitas/FFLCH/USP e FESPSP, 2001.

COMPARATO, Fabio Konder. A afirmação histórica dos direitos humanos. $3^{\mathrm{a}}$ ed. São Paulo: Saraiva, 2004.

COUTINHO, Carlos Nelson. Contra a corrente. Ensaios sobre democracia e socialismo. $2^{\mathrm{a}}$ ed. São Paulo: Cortez, 2008.

CRUZ, Paulo Márcio. Fundamentos históricos, políticos e jurídicos da seguridade social. In: ROCHA, Daniel Machado da; SAVARIS, José Antônio (coord). Curso de Especialização em Direito Previdenciário. V. I. Curitiba: Juruá Editora, 2006, p. 11-92. 
DAS, Raju J. State theories: a critical analysis. Science \& Society, New York, Vol. 60. No 1, p. 27/57, Spring 1996.

DELLA VOLPE, Galvano. Rousseau e Marx. A liberdade igualitária. $4^{\mathrm{a}}$ ed. Tradução de Antonio José Pinto Ribeiro. Lisboa: Edições 70, ano 1982, p.15-79.

DEJOURS, Christophe. A banalização da injustiça social. Tradução de Luiz Alberto Monjardim. Rio de Janeiro: Fundação Getúlio Vargas, 1999, p. 13-59.

DINIZ, Antônio Carlos de Almeida. Teoria da legitimidade do direito e do Estado: uma abordagem moderna e pós-moderna. São Paulo: Landy editora, 2006.

EDELMAN, Bernard. La légalization de la classe ouvrière. L`entreprise. Paris: Christian Bourgois Editeur, 1978.

ENGELS, Friedrich. A origem da família, da propriedade privada e do Estado. $2^{\mathrm{a}}$ Ed. Tradução de Ciro Mioranza. São Paulo: Escala, s.a.

ESPING-ANDERSEN, Gosta. As três economias políticas do Welfare State. Lua Nova, Cedec, n²4, p. 85/116, Set/91.

ESTANQUE, Elísio. A reinvenção do sindicalismo e os novos desafios emancipatórios: Do despotismo local à mobilização global. In SANTOS, Boaventura de Sousa (org.). Trabalhar o mundo: os caminhos do novo internacionalismo operário. Rio de Janeiro: Civilização Brasileira, 2005, p. 359-401.

FAHEL, Murilo Cássio Xavier. Desigualdades em saúde por estratos ocupacionais no Brasil: análise comparada entre 1998 e 2003. Disponível em: http://www.eg.fjp.mg.gov.br/index.php/publicacoes/textos-para-discussao/139-textospublicados-em-2009/997-desigualdades-em-saude-por-estratos-ocupacionais-no-brasilanalise-comparada-entre-1998-e-2003. Acessado em 04/12/09.

FALEIROS, Vicente de Paula. A política social do Estado capitalista. 11 a ed. São Paulo: Cortez, 2008. 
FERNANDES, Ana Elizabete Simões da Mota. Cultura da crise e seguridade social: um estudo sobre as tendências da previdência e da assistência social brasileira nos anos 80 e 90 . São Paulo: Cortez, 1995.

FERNANDES, Florestan. A revolução burguesa no Brasil: ensaio de interpretação sociológica. 5 ed. São Paulo: Globo, 2006, p. 337-424.

FERNANDES, Luis. Neoliberalismo e reestruturação capitalista. In: SADER, Emir; GENTILI, Pablo (org). Pós-Neoliberalismo: as políticas sociais e o Estado democrático. $8^{\mathrm{a}}$ ed. Rio de Janeiro: Paz e Terra, 1995, p. 54-61.

FIORI, José Luís. Os economistas e a crise. Disponível em: http://www.ip.urfj.br/aparte/pdfs/os_economistas_e_a_crise_fiori.pdf. Acessado em 30/08/09.

O sistema interestatal capitalista no inicio do século XXI. In: MEDEIROS, Carlos Aguiar de; Da COSTA, José Luís; SERRANO, Franklin P. O mito do colapso do poder americano. Rio de Janeiro: Record, 2008, p. 11-70.

GRAU, Eros Roberto. A ordem econômica na Constituição de 1988. 10a ed. São Paulo: Malheiros, 2005.

HELLER, Agnes; FEHER, Ferenc. A condição política pós-moderna. $2^{\mathrm{a}}$ ed. Tradução de Marcos Santarrita. Rio de Janeiro: Civilização Brasileira, 2002.

IANNI, Octavio. O ciclo da revolução burguesa. Petrópolis: Vozes, 1984, p.11-44.

KANT, Immanuel. A paz perpétua e outros opúsculos. Tradução de Artur Morão. Lisboa: Edições 70, p. 11-19 e 119/171.

.Principios metafisicos del derecho. Nota preliminar de Francisco Ayala. Buenos Aires: Editorial Americalee, 1943.

KASHIURA JÚNIOR, Celso Naoto. Crítica da igualdade jurídica - Contribuição ao pensamento jurídico marxista. São Paulo: Quartier Latin, 2009. 
LENIN, Vladimir Ilitch. O Estado e a revolução: o que ensina o marxismo sobre o Estado e o papel do proletariado na revolução. Tradução de Aristides Lobo. São Paulo: Centauro, 2007.

LOSURDO, Domenico. Democracia ou Bonapartismo. Triunfo e decadência do sufrágio universal. Tradução de Luiz Sérgio Henriques. Rio de Janeiro: Editora UFRJ, 2004.

Hegel, Marx e a tradição liberal. Liberdade, igualdade, Estado. Tradução de Carlos Alberto F.N.Dastoli. São Paulo: Unesp, 1998.

LÖWY, Michael. As Aventuras de Karl Marx contra o Barão de Munchhausen: marxismo e positivismo na sociologia do conhecimento. $8^{\mathrm{a}}$ ed. Tradução de Juarez Guimarães e Suzanne Felicie Lewy. São Paulo: Cortez, 2007.

Figuras do marxismo weberiano. Disponível em: http://nplyriana.adv.br/artigos1/marxismo_weberiano.doc. Acessado em 29/12/07.

LUKÁCS, Georg. História e Consciência de Classe. Estudos sobre a dialética marxista. Tradução de Rodnei Nascimento. São Paulo: Martins Fontes, 2003.

MACHADO, Luis Antonio. A sociabilidade excludente. In: SADER, Emir; GENTILI, Pablo (Org). Pós-Neoliberalismo: as políticas sociais e o Estado democrático. $8^{\mathrm{a}}$ ed. Rio de Janeiro: Paz e Terra, 1995, p.134-137.

MAIOR, Jorge Luiz Souto; CORREIA, Marcus Orione Gonçalves. O que é direito social? In: CORREIA, Marcus Orione Gonçalves (org). Curso de direito do trabalho. Vol. 1. São Paulo: LTr, 2007, p. 13-40.

MAMAN, Jeannette Antonios. Fenomenologia existencial do direito. Crítica do pensamento jurídico brasileiro. $2^{\mathrm{a}}$ ed. São Paulo: Quartier Latin, 2003.

MANDEL, Ernest. O capitalismo tardio. Tradução de Carlos Eduardo S. Matos, Regis de Castro Andrade e Dinah de Abreu Azevedo. São Paulo: Abril Cultural, 1982, p. 367-410. 
Tratado de economia marxista. Tomo I. México: Ediciones Era, 1969, p.

119-166.

MAQUIAVEL, Nicolau. O príncipe. Tradução de Antônio Caruccio-Caporale. Porto Alegre: L\&PM, 1998.

MARCUSE, Herbert. Razão e revolução. Hegel e o advento da teoria social. $5^{\mathrm{a}}$ ed. Tradução de Marilia Barroso. São Paulo: Paz e Terra, 2004, p. 15-35.

MARX, Karl. A questão judaica. Disponível em: http://www.marxists.org/portugues/marx/1843/questaojudaica.htm. Acessado em 19/02/08.

A revolução antes da revolução. São Paulo: Expressão Popular, 2008.

. Contribuição a crítica da economia política. $2^{\mathrm{a}}$ ed. Tradução de Florestan Fernandes. São Paulo: Expressão Popular, 2007, p. 7-48 e 235-283.

Crítica ao Programa de Gotha. Disponível em: http://virtualbooks.terra.com.br/freebook/colecaoridendo/critica_ao_programa_de_gotha.htm . Acessado em 02/07/08.

Crítica da filosofia do direito de Hegel. Tradução de Rubens Enderle e Leonardo de Deus. São Paulo: Boitempo, 2005.

Manuscritos Econômico-Filosóficos. Tradução de Jesus Ranieri. São Paulo: Boitempo, 2004.

O capital: crítica da economia política. Livro I. $26^{\mathrm{a}}$ ed. Tradução de Reginaldo Sant`Anna. Rio de Janeiro: Civilização Brasileira, 2008

MARX, Karl. ENGELS, Friedrich. A ideologia alemã. Tradução de Rubens Enderle. São Paulo: Boitempo, 2007, p. 9-98. 
A ideologia alemã. $3^{\mathrm{a}}$ ed. Tradução de Luis Cláudio de

Castro e Costa. São Paulo: Martins Fontes, 2007.

MASCARO, Alysson Leandro. Introdução ao estudo do direito. São Paulo: Quartier Latin, 2007.

.Introdução à filosofia do direito. Dos modernos aos contemporâneos. $2^{a}$ ed. São Paulo: Atlas, 2008.

. Lições de sociologia do direito. São Paulo: Quartier Latin, 2007.

Para uma crítica da legalidade no Brasil contemporâneo. 2002.

266 f. Tese (Doutorado em Filosofia do Direito) - Faculdade de Direito, Universidade de São Paulo, São Paulo, 2002.

MILIBAND, Ralph. O Estado na sociedade capitalista. Tradução de Fanny Tabak. Rio de Janeiro: Zahar editores, 1972, p. 219-320.

MOTTA, Luiz Eduardo. Direito, Estado e Poder: Poulantzas e o seu confronto com Kelsen. 2008, Caxambu. Marxismo e Ciências Sociais. São Paulo: Anpocs, 2008. Disponível em: http://200.152.208.135/anpocs/trab/adm/impressao_gt.php?id_grupo=7\&publico=S\&PHPSES $\underline{\mathrm{SID}=52867 \mathrm{e} 2 \mathrm{ae} 18 \mathrm{fb} 529 \mathrm{c} 70 \mathrm{~b} 893 \mathrm{e} 940 \mathrm{c} 8263}$. Acessado em 07/06/09.

MUZIO, Gabriele. A globalização como estágio de perfeição do paradigma moderno: uma estratégia possível para sobreviver à coerência do processo. In: OLIVEIRA, Francisco de; PAOLI, Maria Célia (org). Os sentidos da democracia. Políticas do dissenso e hegemonia

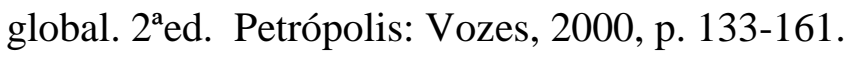

NAVES, Márcio Bilharinho. A “ilusão da jurisprudência”. Disponível em: http://www.pucsp.br/neils/downloads/v7_artigo_marcio_naves.pdf. Acessado em 11/08/09. Marxismo e direito. Um estudo sobre Pachukanis. São Paulo:

Boitempo, 2008. 
Marx. Ciência e revolução. São Paulo: Moderna; Campinas:

Editora da Unicamp, 2000.

NISHIJIMA, Marislei; BIASOTO Júnior, Geraldo; CYRILLO, Denise Cavallini. Análise econômica da interação entre saúde pública e privada no Brasil: tratamentos de alta complexidade. Disponível em: http://www.anpec.org.br/encontro2006/artigos/A06A107.pdf. Acessado em 27/09/09.

NEGRI, Antonio; HARDT, Michael. O trabalho de Dioniso: para a crítica ao Estado pósmoderno. Tradução de Marcello Lino. Juiz de Fora: Editora UFJF - Pazulin, 2004.

NETTO, José Paulo. Capitalismo monopolista e serviço social. $6^{\mathrm{a}}$ ed. São Paulo: Cortez, 2007.

NIETZSCHE, Friedrich W. Genealogia da moral. Uma polêmica. Tradução de Paulo César de Souza. São Paulo: Companhia das Letras, 1998.

NOBRE, Marcos. Lukács e os limites da reificação Um estudo sobre história e consciência de classe. São Paulo: Editora 34, 2001.

OLIVEIRA, Francisco de. Os direitos do antivalor. A economia política da hegemonia imperfeita. Petropólis: Vozes, 1998, p. 9-61.

Privatização do público, destruição, da fala e anulação da política: o totalitarismo neoliberal. In: OLIVEIRA, Francisco de; PAOLI, Maria Célia (org). Os Sentidos da Democracia Políticas do dissenso e hegemonia global. 2aed. Petrópolis: Vozes, 2000, p.55-81.

PAOLI, Maria Célia. Apresentação e Introdução. In: OLIVEIRA, Francisco de; PAOLI, Maria Célia (org). Os Sentidos da Democracia Políticas do dissenso e hegemonia global. $2^{\mathrm{a}}$ ed. Petrópolis: Vozes, 2000, p. 7-23.

PASUKANIS, Eugeny Bronislanovich. Teoria geral do direito e o marxismo. Tradução de Paulo Bessa. Rio de Janeiro: Renovar, 1989. 
PIOVESAN, Flávia. Direitos humanos e o direito constitucional internacional. 9a ed. São Paulo: Saraiva, 2008.

POULANTZAS, Nicos. O Estado, o poder, o socialismo. Tradução de Rita Lima. Rio de Janeiro: Graal, 1980.

Poder político e classes sociais. Tradução de Francisco Silva. São

Paulo: Martins Fontes, 1977.

PRADO, Antonio. A controvérsia da crise do fordismo e a transição pós-fordista: algumas reflexões sobre o caso brasileiro. In: Emprego e desenvolvimento tecnológico: processos de integração regional. São Paulo: Dieese, p.15-28, 1999.

RAMALHO, José Ricardo. Movimento sindical e política neoliberal. In: SADER, Emir; GENTILI, Pablo (org). Pós-Neoliberalismo: as políticas sociais e o Estado democrático. $8^{\text {a ed. }}$ Rio de Janeiro: Paz e Terra, 1995, p. 125-133.

ROSENMANN, Marcos Roitman. Os dilemas da democracia no Século XXI. Tradução de José Argüello Franco. Revista Universidade e Sociedade, Brasília, ano XII, nº 28, p. 18-26, Nov/02.

SADER, Emir. Estado e política em Marx: para uma critica da filosofia política. São Paulo: Cortez, 1993, p.7-53.

SALAMA, Pierre. Pobreza e exploração do trabalho na América Latina. Tradução de Emir Sader. São Paulo: Boitempo Editorial, 1999, p. 41-55 e 85-124.

SALAMA, Pierre; VALIER, Jacques. Uma introdução à economia política. Tradução de Carlos Nelson Coutinho. Rio de Janeiro: Civilização Brasileira, 1975, p. 85-124 e 175-203.

SALGADO, Joaquim Carlos. A idéia de justiça em Kant. $2^{\mathrm{a}}$ ed. Belo Horizonte: UFMG, 1995, p. 152-334.

SANTOS, Cleusa. A seguridade social e a esfera dos serviços. Universidade e Sociedade, Brasília, Ano XI, n²7, p. 62-68, junho 02. 
SANTOS, José Alcides Figueiredo. Mudanças na estrutura de posições e segmentos de classe no Brasil. Dados, Rio de Janeiro, v.44, n.1, 2001. Disponível em: http://www.scielo.br/scielo.php?script=sci_arttext\&pid=S001152582001000100005\&lng=pt \&nrm=iso. Acessado em 04/07/07.

Uma classificação socioeconômica para o Brasil. Revista Brasileira de Ciências Sociais, São Paulo, vol.20, ${ }^{\circ}$ 58, jun 2005. Disponível em: http://www.scielo.br/scielo.php?script=sci_arttext\&pid=S010269092005000200002\&lng=pt \&nrm=iso. Acessado em 04/07/07.

SANTOS, Laymert Garcia. Tecnologia, perda do humano e crise do sujeito de direito. (In) OLIVEIRA, Francisco de; PAOLI, Maria Célia (org). Os Sentidos da Democracia Políticas do dissenso e hegemonia global. $2^{a}$ ed. Petrópolis: Vozes, 2000, p. 291/306.

SARLET, Ingo Wolfgang. Dignidade da pessoa humana e direitos fundamentais na Constituição Federal de 1988. $4^{\text {a }}$ Ed. Porto Alegre: Livraria do Advogado editora, 2006, p.2527 e $84-145$.

SAUVIAT, Catherine. Os fundos de pensão e os fundos mútuos: principais atores da finança mundializada e do novo poder acionário. In: CHESNAIS François (org.). A finança mundializada. Raízes sociais e políticas, configuração, consequiências. Tradução de Rosa Marques e Paulo Nakatani. São Paulo: Boitempo Editorial, 2005, p. 109/132.

SAVARIS, José Antonio. O judiciário e a política de retração sistemática da previdência social brasileira. In: FOLMANN, Melissa; FERRARO, Suzani Andrade (coord.). Previdência nos 60 anos da Declaração dos Direitos Humanos e 20 anos da Constituição brasileira. Curitiba: Juruá, 2008, p. 139/179.

SERRANO, Franklin. A economia americana, o padrão dólar flexível e a expansão mundial nos anos 2000. (In) MEDEIROS, Carlos Aguiar de; Da COSTA, José Luís; SERRANO, Franklin P. O mito do colapso do poder americano. Rio de Janeiro: Record, 2008, p. 71-172.

SILVA, José Afonso. Curso de direito constitucional positivo. $26^{\mathrm{a}}$ ed. São Paulo: Malheiros, 2006. 
SIQUEIRA, Carlos Eduardo; CASTRO, Hermano; ARAÚJO, Tânia Maria de; A globalização dos movimentos sociais: resposta social à globalização corporativa neoliberal. Ciência \& Saúde Coletiva, Rio de Janeiro, v.8, n.4, 2003. Disponível em: http://www.scielo.br/scielo.php?script=sci_arttext\&pid=S141381232003000400002\&lng=pt \&nrm=iso. Acessado em 03/07/07.

SOUZA FILHO, Carlos Frederico Mares de. Os direitos invisíveis. In: OLIVEIRA, Francisco de; PAOLI, Maria Célia (org). Os sentidos da democracia. Políticas do dissenso e hegemonia global. 2aed. Petrópolis: Vozes, 2000, p. 307-334.

SUPLICY, Eduardo. Da renda mínima a renda básica no Brasil. In: CORREIA, Marcus Orione Gonçalves; CORREIA, Érica Paula Bacha (coord). Direito previdenciário e Constituição. São Paulo: LTr, 2004, p. 55-93.

TELLES, Vera da Silva. Direitos sociais: afinal do que se trata? Belo Horizonte: UFMG, 2006.

THERBORN, Göran. A crise e o futuro do capitalismo. In: SADER, Emir; GENTILI, Pablo (org). Pós-Neoliberalismo: as políticas sociais e o Estado democrático. $8^{\mathrm{a}} \mathrm{ed}$. Rio de Janeiro: Paz e Terra, 1995, p. 39-53.

TOURAINE, Alain. Crítica da modernidade. $7^{\mathrm{a}}$ ed. Tradução de Elia Ferreira Edel. Petrópolis: Vozes, 2002, p. 9-209.

VAN PARIJS, Philippe. A renda básica: Por que, como e quando nos países dos hemisférios norte e sul? Econômica, Rio de Janeiro, v.4, n.1, p. 75/93, jun/02.

Renda básica: renda mínima garantida para o século XXI? Estudos avançados, São Paulo, vol.14, $\mathrm{n}^{\circ} 40, \quad$ sept/dec 2000. Disponível em: http://www.scielo.br/scielo.php?script=sci_arttext\&pid=S0103-40142000000300017. Acessado em 02/12/09.

VIANNA, Maria Lucia Teixeira Werneck. A americanização (perversa) da seguridade social no Brasil. Estratégias de bem-estar e políticas públicas. 2ª ed. Rio de Janeiro: Revan: UCAM, IUPERJ, 2000, p. 138-231. 
WACQUANT, Loïc. Punir os pobres. A nova gestão da miséria nos Estados Unidos. Rio de Janeiro: Instituto Carioca de Criminologia. F. Bastos, 2001, p.7-50.

WEBER, Max. A ética protestante e o espírito do capitalismo. Tradução de José Marcos Mariani de Macedo. São Paulo: Companhia das Letras, 2004.

Ciência e política. Duas vocações. $3^{\mathrm{a}}$ ed. Tradução de Leônidas Hegenberg e Octany Silveira da Mota. São Paulo: Cultrix, 1967.

Economia e sociedade: fundamentos da sociologia compreensiva. V. I. $4^{\mathrm{a}}$ ed. Tradução de Regis Barbosa e Karen E. Barbosa. São Paulo: Imprensa Oficial do Estado de São Paulo, 2004, p. 3-138.

Economia e sociedade: fundamentos da sociologia compreensiva. V. II. Tradução de Regis Barbosa e Karen Elsabe Barbosa. São Paulo: Imprensa Oficial do Estado de São Paulo, 2004, p. 1-153 e 517-580.

WEFFORT, Francisco Correia. Qual democracia? São Paulo: Companhia das Letras, 1992, p. 85-119.

WOOD, Ellen Meiksins. Democracia contra capitalismo. A renovação do materialismo histórico. Tradução de Paulo Cezar Castanheira. São Paulo: Boitempo, 2003. 


\section{Resumo}

O presente estudo teve por objetivo estudar os direitos sociais para além do tema questão da redução do Estado, ocorrida com a derrocada do Estado Social. Ele dirige-se precipuamente para os limites e potencialidades dos direitos sociais no interior da esquadratura capitalista, abarcando suas origens, possibilidades de consolidação e eventuais refrações. Valendo-se dos enfoques econômicos, políticos e jurídicos como ferramentais para estudar a movimentação dos direitos sociais no curso do século XX e no início do século XXI, o trabalho tende a concluir que os direitos sociais são hoje o grande objeto de disputa em uma sociedade calcada pela hegemonia do capital. Nesse sentido, o caso brasileiro é uma boa mostra desta disputa instalada com um elemento distintivo - as consequências advindas do subdesenvolvimento e da inserção periférica no capitalismo.

Palavras-chave: direitos sociais dentro da ordem capitalista - estrutura potencialidades e limites. 


\begin{abstract}
The aim of this work is to study the social rights beyond the issue of the State decreasing after Welfare State's crisis. The work analyses the upper limits and the potentialities of the social rights inside the capitalism structure, studying their origins, consolidations and refractions. Using the economical, political and juridical view point, this work studies the social rights during the XX and XXI century and tends to conclude that social rights are nowadays the biggest issue in our society based on capital`s hegemony. In this way the Brazilian case is a good sample of this dispute which could be introduced a distinctive element - the consequences from the underdevelopment and secondary role in capitalism's world.
\end{abstract}

Key-words: social rights inside the capitalism world - structure - potentialities and upper limits. 